CARLOS OTÁVIO FERREIRA DE ALMEIDA

\title{
CONCORRÊNCIA INTERNACIONAL E TRIBUTAÇÃO DA RENDA NO BRASIL
}

Faculdade de Direito da Universidade de São Paulo

São Paulo - 2012 


\title{
CARLOS OTÁVIO FERREIRA DE ALMEIDA
}

\section{CONCORRÊNCIA INTERNACIONAL E TRIBUTAÇÃO DA RENDA NO BRASIL}

\author{
Tese apresentada à banca examinadora da \\ Faculdade de Direito da Universidade de São \\ Paulo como requisito para a obtenção do título \\ de Doutor em Direito.
}

Orientação: Professor Titular Dr. Luís Eduardo Schoueri

Faculdade de Direito da Universidade de São Paulo São Paulo - 2012 
Banca Examinadora: 


\section{Dedicatória}

A minha esposa Rakel.

A minha filha Clara.

A meus pais e irmão. 
Agradecimentos

A certeza de que deveria dedicar-me aos estudos no campo do direito tributário e, especialmente, à docência, surgiu em terra distante, ao travar contato mais estreito com dois modelares Professores: Michael Friel e Lawrence Lokken. O primeiro, Diretor do Programa de Pós-Graduação em Direito Tributário da University of Florida (Levin College of Law); o segundo, meu orientador nas pesquisas do mestrado naquela instituição. Registro aqui minha mais profunda gratidão nem tanto pelas diversas orientações seguras que me passaram, mas pela constância de seus exemplos nas mais diversas atividades acadêmicas. Ambos resumem, em síntese, o que se deve esperar daqueles que optam pelo ofício de Professor.

Agradeço ao Professor Alaôr Caffé Alves, Coordenador do Curso de Direito das Faculdades de Campinas - FACAMP, cujo entusiasmo pelas questões acadêmicas servem-me de estímulo.

Agradeço ao Professor Luís Eduardo Schoueri, pelo inestimável benefício que proporciona ao ensino do direito tributário no Brasil.

Meu reconhecimento, ainda, a todos cujas proposições, questionamentos e dúvidas serviram-me como valioso material de aprendizado, tornando minha jornada no doutorado desafiadora e prazerosa: Luís Renato Vedovato, Roberto Cillo, Maurício Ricardo Pinheiro da Costa, Sérgio Pappini, Alexandre Rêgo Monteiro, Henrique Erbolato, Leonardo Castro, Rodrigo de Freitas, Natalie Silva, João Victor Guedes, Flavio Rubinstein, Gustavo Vettori, Mauro Silva, Raquel Ramos Machado, Luís Flávio Neto, Paulo Victor Vieira da Rocha, Victor Polizzeli, Renato Faria, Fábio Nogueira, Cesar Seijas de Andrade, André Ramos Carvalho e, mais especialmente, Lucas Bevilacqua Cabianca.

Aos amigos que, de alguma forma, contribuíram com a produção deste trabalho: Róbson Augusto Dainez Condé, Carlos Eduardo Raphael Nunes, Marcelo de Camargo Andrade e Luís Miguel Garcia Minguez.

A todos os meus alunos, razão pela qual comprometo-me a melhor me conhecer e a superar minhas diversas limitações.

Por fim, minha gratidão a Eloíza Tinoco e Márcio Souza Martins, responsáveis, respectivamente, pelas bibliotecas do Instituto Brasileiro de Direito Tributário -IBDT e das Faculdades de Campinas- FACAMP. 
A luz compreende as trevas,

vencendo-as e triunfando sobre elas em sua infinitude,

ao passo que as trevas não compreendem, dominam

nem igualam a luz -

é admirável ver como suportam mal a comparação.

Giordano Bruno (1548-1600) 


\section{RESUMO}

O presente trabalho investiga a concorrência tributária internacional sob a perspectiva do imposto de renda brasileiro. Para tanto, procura contextualizar a tributação na atualidade, indicando desafios à atuação do Estado comprometido com sua inserção internacional.

Comumente, o Estado competitivo adota políticas atrativas ao investimento externo que encontram limitações na ordem jurídica interna e internacional. Internamente, a concessão de incentivos fiscais deve se conformar à moldura imposta por princípios constitucionais atuantes sobre as ordens tributária e econômica. No plano internacional, deve respeitar as regras de liberalização do comércio, área de atuação da OMC. Adicionalmente, cláusulas de incentivo podem ter papel relevante na busca pelo desenvolvimento através de acordos de bitributação.

Tomando a atração do investimento estrangeiro direto como uma das vias de promoção do desenvolvimento, tarefa a que se vê obrigado o legislador brasileiro por comando constitucional (art. $3^{\circ}$, II), serão aplicados testes de coerência sobre alguns institutos típicos da tributação da renda. A resposta dos testes permitirá concluir se a atuação do legislador infraconstitucional confere maior competitividade ao País e, em caso positivo, se o faz com o devido respeito aos limites impostos pela ordem tributária e econômica, ou se a norma precisa de reforma para atender aos reclames da competitividade internacional, cada vez mais acirrada na era da pós-modernidade.

\section{Palavras-chave:}

\section{Concorrência tributária internacional}

Incentivos fiscais

Investimento Estrangeiro Direto

Acordos de bitributação

Tributação da renda 


\begin{abstract}
The present study aims to investigate international tax competition from the perspective of the Brazilian income tax. To do so, it seeks contextualize taxation currently, indicating challenges to the State that is committed to its own international insertion.

Commonly, the competitive State adopts attractive policies to foreign investment which are restricted by both internal and international juridical order. Internally, granting fiscal incentives should conform the frame imposed by constitutional principles of taxation and economic orders. At the international level, it should respect trade liberalization rules which are under the scope of the World Trade Organization. Additionally, incentive clauses on tax treaties may be relevant to foster development.

Taking attraction of foreign direct investment as a way of promoting development, a task Brazilian lawmakers have to observe in accordance with a constitutional rule (art. $3^{\circ}$, II), consistency tests are applied on some typical income tax institutes. Tests results can confirm whether the legislator is acting to promote a competitive State and, if so, whether it does so observing those limits imposed by tax and economic orders or if rules shall be reformed in order to follow the international competition demands, increasingly fierce in the postmodernity era.
\end{abstract}

\title{
Keywords:
}

\section{International tax competition}

Tax incentives

Foreign Direct Investment

Tax treaties

Income taxation 


\section{RÉSUMÉ}

La présente étude recherche la concurrence tributaire internationale selon la perspective de l'impôt sur les revenus au Brésil. Pour cela, on fait la contextualisation de la tributation aujour d'hui, en rélevant des défis à la perfomance del État au tant que engagé vers son insertion internationale.

En général, 1'État competitif adopte des politiques pour inciter des investissements étrangers, que, de leur coté, envisagent des limitations d'ordre juridique interne et internationale. Dans le cadre interne, la concession des incitations fiscales doivent se conformer aux impositions constitutionnels que réglent les ordres tributaire et économique. Au niveau internationale, des régles de libéralisation du commerce doivent être respectées, matière reglée par 1’OMC. Au délà, des clauses d'incitation peuvent avoir un rôle significatif dans la recherche du dévéloppement par l'intermediaire des accords de double imposition.

En considerant que l'attraction de l'investissement étranger constitue une des voies de promotion du développement, il s'agit d'une une obbligation à laquelle le legislateur brésilien est soumis par command constitutionel (art. $3^{\circ}$, II), cas où il faudra des testes de coherence sur quelques instituts typiques de la tributation des revenus. Leur réponse permettra conclure si la performance du legislateur infraconstitutionnel confére une plus grande competititivité au Pays, et, en cas positif, si le fait en respectant les limites imposées par l'ordre tributaire et économique, ou encore si la norme demande des reformulations pour atteindre aux réclames de la competitivité internationnale, de plus en plus serrée dans l’ère de la postmodernité.

\section{Les mots clefs:}

\section{Concurrence fiscale internationale}

Incitations fiscales

Investissement étranger direct

Conventions préventives de la double imposition

\section{Impôt sur la revenu}




\section{ÍNDICE DO CONTEÚDO}

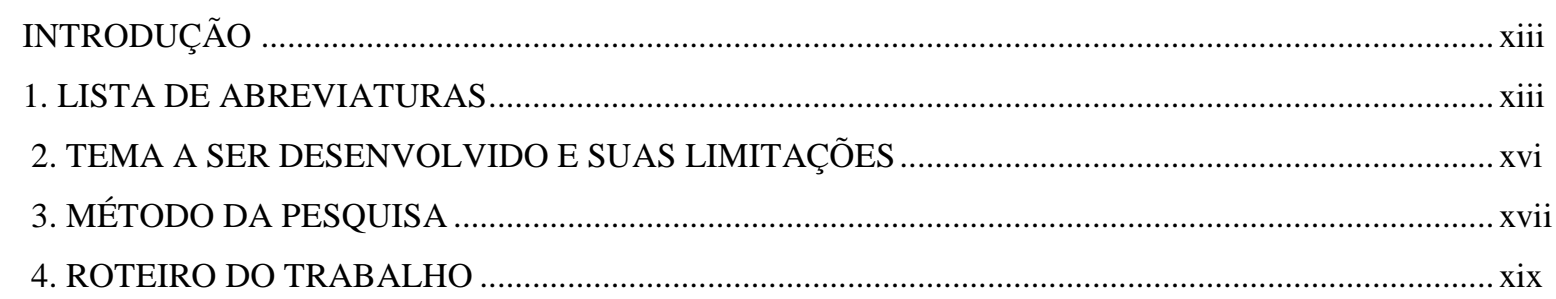

\section{CAPÍTULO I - TRIBUTAÇÃO INTERNACIONAL E ORDEM JURÍDICA PÓS-MODERNA}

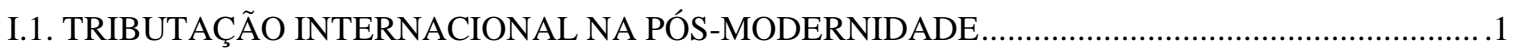

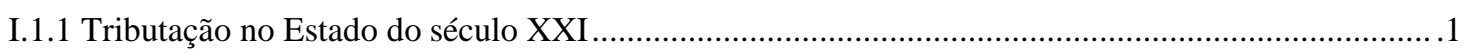

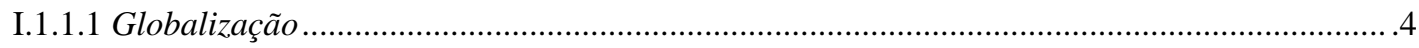

I.1.1.2 Integração econômica e livre mobilidade de bens,pessoas, serviços e capitais ....................... 8

I.1.1.3 A importância crescente da tributação da renda no contexto pós-moderno .............................. 11

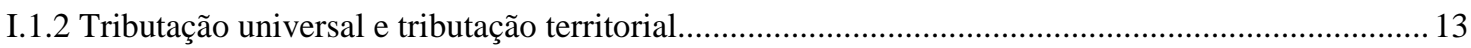

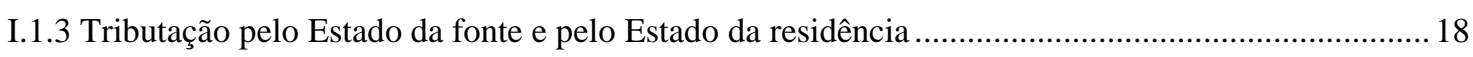

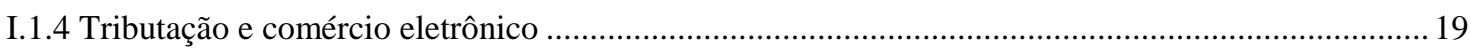

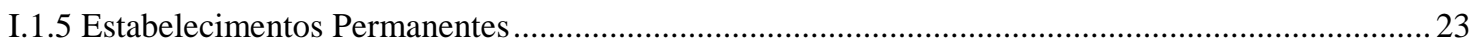

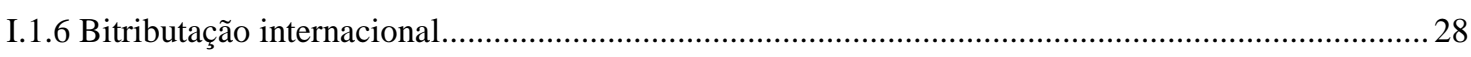

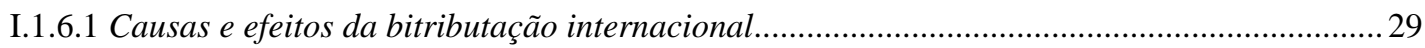

I.1.6.2 Medidas unilaterais de combate à bitributação: imputação e isenção.......................................32

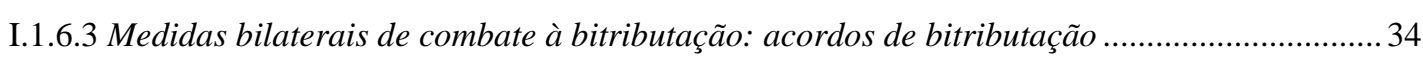

I.1.7 Relação entre Direito Tributário Internacional e Direito Econômico ..................................................35

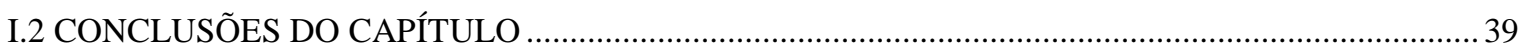

\section{CAPÍTULO II- LIMITAÇÕES JURÍDICAS À CONCORRÊNCIA TRIBUTÁRIA INTERNACIONAL}

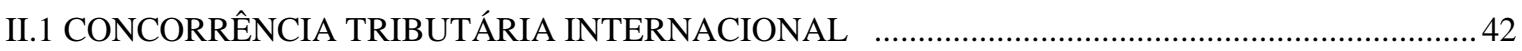

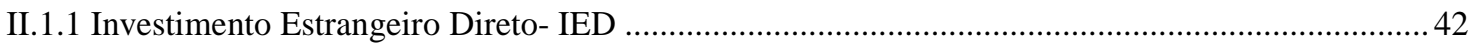

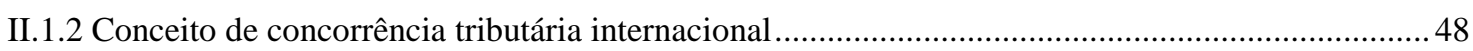

II.1.3 Aspectos positivos e negativos da concorrência tributária internacional .........................................51

II.1.4 Paraísos fiscais e regimes de tributação privilegiados......................................................................52 
II.1.4.1 Relatório da OCDE sobre concorrência tributária nociva -1998 .........................................52

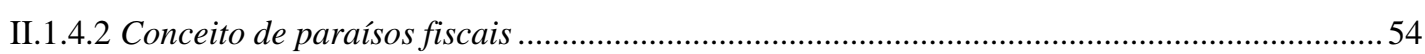

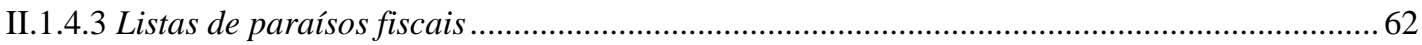

II.1.5 Mitigação da concorrência tributária internacional: cooperação............................................... 64

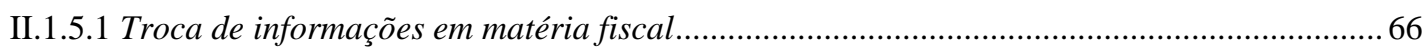

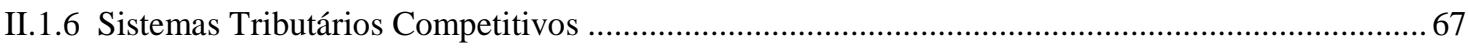

II.2.BALIZAS DO ORDENAMENTO JURÍDICO À CONCORRÊNCIA TRIBUTÁRIA........................71

II.2.1 O Estado competitivo sob o exame da proporcionalidade .................................................. 71

II.2.1.1 Concorrência tributária aceitável e concorrência tributária nociva ................................. 71

II.2.1.2 Exame de proporcionalidade ........................................................................................ 74

II.2.2 Critérios informadores da tributação da renda no Brasil ..................................................... 78

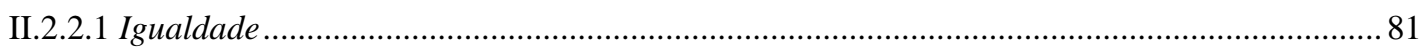

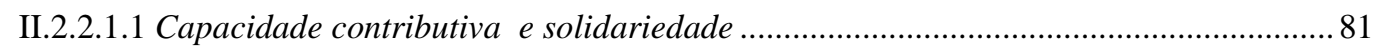

II.2.2.1.2 Progressividade e Proporcionalidade ..................................................................... 84

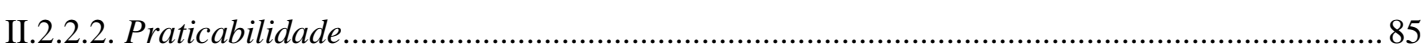

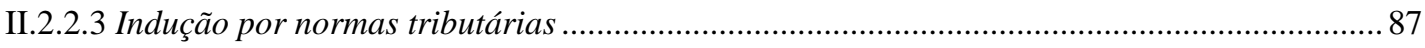

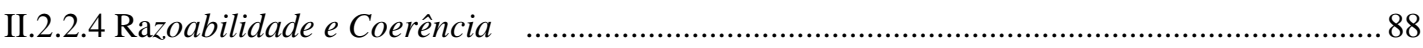

II.2.2.5 Outros princípios constitucionais relevantes para a tributação da renda ............................89

II.2.3 Fiscalidade e indução sob a Ordem Econômica....................................................................... 91

II.2.3.1 Limitações da Ordem Econômica às normas tributárias indutoras no plano doméstico....... 91

II.2.3.2 Limitações da Ordem Econômica às normas tributárias indutoras no plano internacional .96

\section{CAPítulo III- A TRIBUTAÇÃo COMO MEIO DE ATRAÇÃo AO INVESTIMENTO ESTRANGEIRO DIRETO}

III.1 INCENTIVOS FISCAIS - REGULAÇÃO E EFICIÊNCIA ....................................................... 107

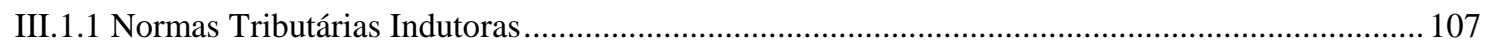

III.1.2 Benefícios fiscais: gastos tributários e subvenções diretas.................................................. 111

III.2. INCENTIVOS FISCAIS NO ÂMBITO DOS ACORDOS DE BITRIBUTAÇÃO ............................. 119

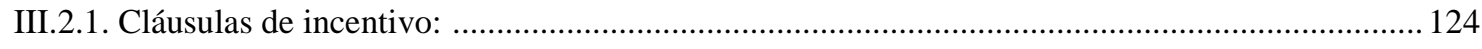

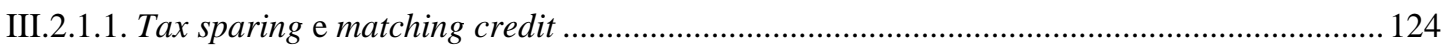

III.2.1.2. Tax Sparing: uma reconsideração ............................................................................. 128

III.2.1.3 Tax Sparing: reconsideração da reconsideração .......................................................... 130

III.2.2 Deve a residência reconhecer os incentivos da fonte?........................................................ 136

III.2.3 Política de negociação de acordos de bitributação e inserção internacional............................... 138

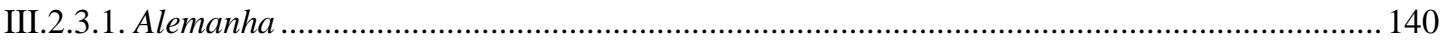

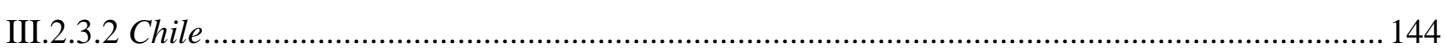

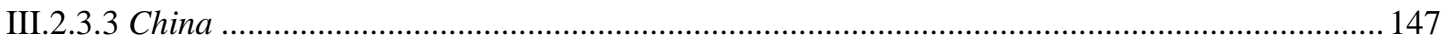




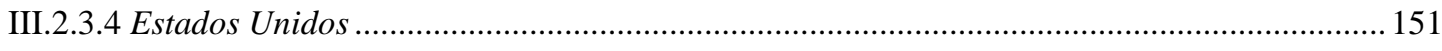

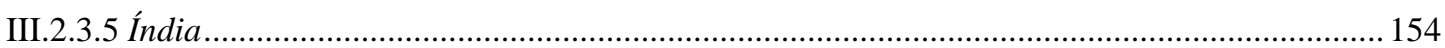

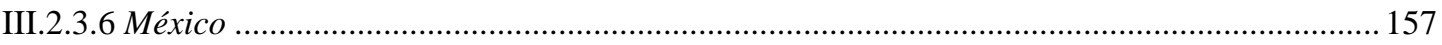

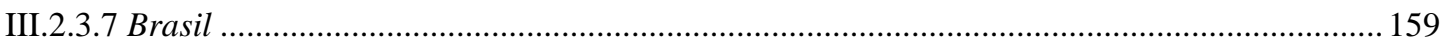

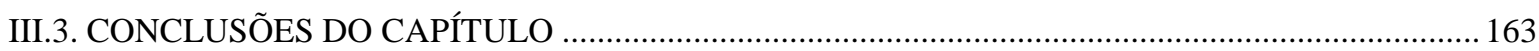

\section{CAPÍTULO IV- TRIBUTAÇÃO DA RENDA E COMPETITIVIDADE INTERNACIONAL}

IV.1 MOLDURA CONSTITUCIONAL DA RENDA NO BRASIL .................................................... 167

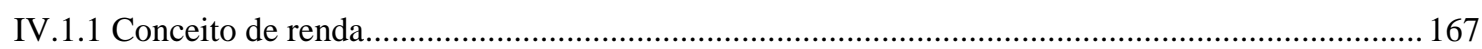

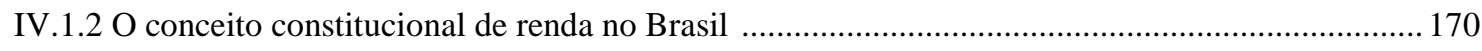

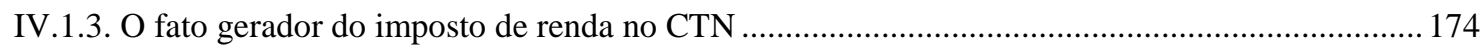

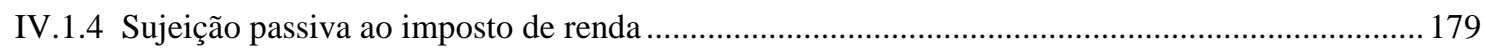

IV.1.5 Bases de cálculo do modelo brasileiro do imposto de renda ............................................... 181

IV.2 NOTAS SOBRE O SISTEMA BRASILEIRO DE TRIBUTAÇÃO DA RENDA ............................. 183

IV.2.1 Visão geral do sistema de tributação da renda ................................................................ 183

IV.2.2. Tributação de não-residentes ................................................................................. 186

IV.3 ANÁLISE DA COERÊNCIA DE ALGUNS INSTITUTOS DA TRIBUTAÇÃO DA RENDA À

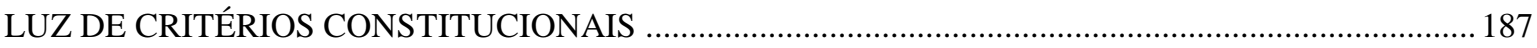

IV.3.1 Integração da tributação de pessoas físicas e jurídicas ........................................................... 188

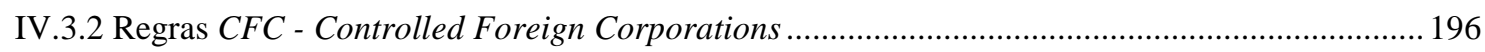

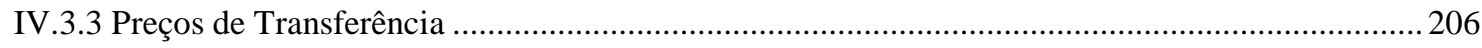

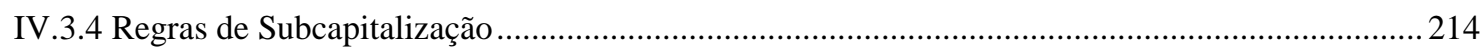

IV.3.5 Compensação de lucros e prejuízos ..............................................................................222

IV.3.6 Regime Fiscal para Grupos de Empresas - Group Tax Regime ............................................2225

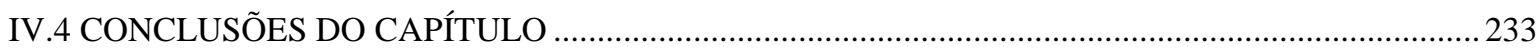

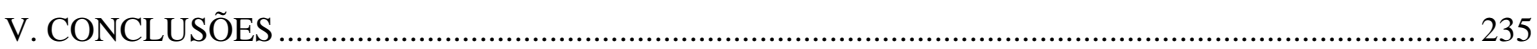

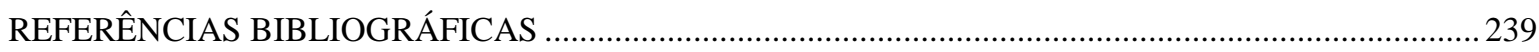




\section{INTRODUÇÃO}

\section{LISTA DE ABREVIATURAS}

AII - Acordo de Investimento Internacional

AIR - Adicional do Imposto de Renda

ASMC - Acordo sobre Subsídios e Medidas Compensatórias

BACEN - Banco Central do Brasil

BIT - Bilateral Investment Treaties - acordos bilaterais de investimento

BIRD - Banco Internacional para Reconstrução e Desenvolvimento ou Banco Mundial

BRIC- Brasil, Rússia, Índia e China

CADE - Conselho Administrativo de Defesa Econômica

CARF - Conselho Administrativo de Recursos Fiscais

CEJ - Corte Européia de Justiça (Tribunal de Justiça da União Européia)

CEPAL - Comissão Econômica para América Latina e o Caribe

CF - Constituição Federal

CFC - Controlled Foreign Corporations

CGI - Code Général des Impôts

CIAT - Centro Interamericano de Administrações Tributárias

CIJ - Corte Internacional de Justiça

CPIJ - Corte Permanente Internacional de Justiça

CSLL - Contribuição Social sobre o Lucro Líquido

EP - Estabelecimento permanente

EUA - Estados Unidos da América

DI- Direito Internacional 
DIP - Direito Internacional Público

DTI - Direito Tributário Internacional

IED -Investimento Estrangeiro Direto

IR - Imposto de Renda

IRPF- Imposto de Renda das Pessoas Físicas

IRPJ - Imposto de Renda das Pessoas Jurídicas

FDI - Foreign Direct Investment

FMI - Fundo Monetário Internacional

LOB - Limitations on benefits clauses

GATT - General Agreement on Tariffs and Trade

GATS - General Agreement on Trade in Services

OMA - Organização Mundial de Aduanas

OCDE- Organização para a Cooperação e Desenvolvimento Econômico

OIC - Organização Internacional do Comércio

OMC - Organização Mundial do Comércio

OSC - Órgão de Solução de Controvérsias da OMC

ONG - Organização Não-Governamental

MAP - Mutual agreement procedures - procedimentos para acordo recíproco

MNE - Multinational Enterprise

NAFTA - North American Free Trade Agreement

NIC - Neutralidade de importação de capital

NEC - Neutralidade de exportação de capital

PED - Países em Desenvolvimento

P\&D - Pesquisa e Desenvolvimento

PD - Países Desenvolvidos 
RIR - Regulamento do Imposto de Renda

RTI - Regime de Tributação Internacional

TCE- Tratado das Comunidades Européias

TFUE - Tratado sobre Funcionamento da União Européia

TIEAS - Tax Information Exchange Agreements

TRIM - Trade Related Investment Measures - medidas de investimento relacionadas ao comércio

TUE - Tratado da União Européia

TRIPs - Trade-Related Aspects of Intellectual Property Rights

UNCTAD - United Nations Conference on Trade and Development

UUEE - União Européia 


\section{TEMA A SER DESENVOLVIDO E SUAS LIMITAÇÕES}

Nos umbrais no século XXI, a pós-modernidade vem provocando alterações cada vez mais velozes nas diversas formas de inter-relação entre os países. Vários são os temas que desafiam o direito internacional do presente e do futuro, tais como o meioambiente, o terrorismo, os direitos humanos, a miséria, a corrupção e tantos outros. Destaca-se deste rol o tema da tributação internacional, fonte primordial de recursos do mais tradicional sujeito de direito internacional: o Estado.

O fenômeno da globalização trouxe severas mudanças no cenário da tributação mundial. A livre movimentação de fatores de produção, especialmente do capital, ameaçando as bases de tributação dos diferentes Estados, estimulou o que se convencionou denominar concorrência tributária internacional. O cerne do fenômeno concorrencial está na pressão internacional exercida sobre a política tributária dos Estados, que passam a ver nos incentivos fiscais uma das principais alavancas para o desenvolvimento.

Embora relevantes, paira sobre os incentivos fiscais a suspeita de que conduzam a uma corrida para o fundo (race to the bottom), frustrando as expectativas de receitas públicas, e de que discriminem o investidor estrangeiro em detrimento do nacional. De toda a sorte, é prática corrente a oferta de incentivos fiscais com vistas a atrair IED.

Conquanto diversos tributos possam exercer influência sobre a alocação do capital externo, este trabalho estará restrito à tributação da renda, sob o campo de atuação do direito tributário internacional, em dimensão interdisciplinar, mais próxima ao direito internacional público e ao direito econômico.

Desde o ocaso do século XIX registram-se negociações bilaterais entre Estados europeus visando a regrar situações econômicas conectadas a ambas as jurisdições. Contudo, foi somente na segunda metade do sec. XX que o direito tributário internacional avançou robustamente, movido pela interação dos agentes econômicos e pela revolução tecnológica. A modificação do cenário internacional tornou mais complexa a tarefa do legislador doméstico, cuja possibilidade de escolha das situações passíveis de imposição ou desoneração tributária, antes livre, passou a sofrer limitações externas pelo mercado e por força de acordos bilaterais, regionais ou multilaterais.

Ao pretender, o legislador brasileiro, atuar sobre os agentes econômicos por meio de incentivos fiscais, basicamente estará limitado por cláusulas não- 
discriminatórias da OMC no campo externo, e vinculado, internamente, pelo "vetor da atuação estatal positiva", 1 segundo o qual deverá buscar a concretização de diversos princípios da Ordem Econômica, que bem poderiam ser acobertados sob o manto de um Princípio do Estado Social Democrático de Direito, ${ }^{2}$ calcados nos pilares da dignidade da pessoa humana e da justiça social.

A interpretação sistemática dos princípios constitucionais da ordem econômica imprime a busca pelo desenvolvimento como matriz da participação do Estado e dos agentes privados na economia brasileira. O papel do Estado contemporâneo não está em atuar diretamente sobre a economia, mas em garantir um ambiente favorável à atuação privada, constrangendo desequilíbrios e distorções que impeçam a concorrência livre. Trata-se da proteção do mercado assegurada pelo Estado. ${ }^{3}$

Este é o contexto em que o tema da presente tese se insere. Necessário conhecer da juridicidade das regras brasileiras de tributação da renda quanto à competitividade internacional. As análises seguintes permitirão inferir se, em matéria de tributação da renda, a atuação do legislador infraconstitucional confere maior competitividade ao Brasil, sob o enfoque da atração de IED. Em caso positivo, mister verificar a adequação das opções efetuadas pelo legislador em vista das diretrizes emanadas pelas ordens tributária e econômica. Em caso negativo, forçoso será concluir se o legislador brasileiro está vinculado à formação de um ambiente propício aos fluxos de IED ou se há liberdade para legislar sem promover a competitividade nacional.

\section{MÉTODO DA PESQUISA}

A pesquisa respeitará ao estilo clássico, desenvolvendo-se, eminentemente, por consultas bibliográficas. Tendo por foco a norma jurídica, a tese pretende descrever os fenômenos atinentes à tributação internacional, mais especialmente aqueles que dizem com a concorrência internacional e suas inter-relações com o direito tributário brasileiro.

\footnotetext{
${ }^{1}$ SCHOUERI, Luís Eduardo. Normas tributárias indutoras e intervenção econômica. Rio de Janeiro: Forense, 2005, pp.83.

${ }^{2}$ Idem, pp.82-83.

${ }^{3}$ ELALI, André. Incentivos fiscais internacionais - concorrência fiscal, mobilidade financeira e crise do Estado. São Paulo: Quartier Latin, 2010, p.83.
} 
As fontes da pesquisa consistirão no direito posto na ordem interna, nos acordos internacionais bilaterais e multilaterais, nas decisões das cortes nacionais e internacionais (e eventualmente regionais), e na doutrina nacional e internacional efetivamente consultadas. Buscar-se-á, assim, o maior número de fontes possível, mesmo em linguagem inacessível ao autor, com o fim de enriquecer o trabalho e servir de auxílio à pesquisa alheia. ${ }^{4}$

Embora dados de outros países sejam tomados como premissas em diversas das análises a seguir, não se pode com isso inferir tratar-se de pesquisa de direito comparado, o que exigiria tomar como fontes as ordens jurídicas e a jurisprudência nos diversos idiomas relativos aos países aqui abordados. Ante a impossibilidade de realizar tal empresa, optou-se pela obtenção de dados junto a pesquisadores estrangeiros de renome, bem como a organizações internacionais como OCDE, ONU, Banco Mundial e OMC. Dados obtidos por uma dessas fontes foram sempre comparados com informações emitidas por outra dessas fontes secundárias. Com isso, pretendeu-se minorar os riscos de inconsistência e atribuir maior segurança ao texto.

A construção do texto atende aos métodos dialético, em que opiniões opostas serão analisadas em face de uma dada situação; histórico, por meio do qual as influências contextuais na construção das normas e práticas internacionais serão vitais para a compreensão dos principais problemas afetos ao tema; e dedutivo, com o qual se pretende concluir acerca das proposições aqui apresentadas.

\section{ROTEIRO DO TRABALHO}

Dividida em quatro capítulos, exclusive as considerações finais, a presente tese dedica-se ao tema da concorrência internacional no âmbito da tributação da renda no Brasil. O que se pretende, ao fim, é saber se relevantes regras ligadas à tributação internacional da renda (CFC, subcapitalização, compensação de prejuízos etc.) atendem ao objetivo estipulado pelo constituinte de fomentar o desenvolvimento, o que será analisado apenas do ponto de vista da competitividade nacional e da atratividade aos fluxos de IED. Caso as regras do imposto de renda satisfaçam a este requisito, deverão observar outras duas exigências constitucionais, traduzidas pelas balizas impostas à atuação do legislador pela ordem tributária e pela ordem econômica.

\footnotetext{
${ }^{4}$ Marchi, Eduardo C. Silveira. Guia de Metodologia Jurídica, 2. ed. São Paulo:Saraiva, 2009, p.128.
} 
O $1^{\circ}$ Capítulo, mais genérico e conceitual, apresenta os desafios ao Estado do sec. XXI impostos pela pós-modernidade. Globalização, mobilidade do capital, integração econômica, dicotomias do tipo fonte e residência ou tributação territorial e universal, revolução tecnológica, comércio eletrônico e bitributação são aluns dos temas obrigatórios na pauta dos Estados que pretendem atrair capital sem descuidar da obtenção de receitas.

No Capítulo 2, adentrar-se-á ao tema da concorrência tributária internacional. Adicionalmente, serão apresentadas as balizas tributárias e econômicas que devem limitar o alcance das normas tributárias de indução, por meio das quais o Estado pode atuar para estimular os agentes econômicos a promoverem determinado fim estatal.

O Capítulo 3 será dedicado aos incentivos fiscais, que podem ser veiculados por normas internas ou por meio dos acordos de bitributação. Se, no passado, os tratados tiveram por escopo a eliminação ou redução da bitributação, hoje podem ser vistos como instrumento de política de desenvolvimento.

O $4^{\circ}$ Capítulo traz os testes de coerência a que se vê jungido o legislador brasileiro. $\mathrm{O}$ vetor de atuação estatal vincula as opções do legislador no sentido de promover o desenvolvimento. Em vista das diversas formas de promoção do desenvolvimento, opta-se por uma das vias que devem conduzir a ele: a da atração de IED. Nesse contexto, a norma que impulsiona o investidor para outro destino estaria coerente com a ordem jurídica pátria? A busca pela atratividade ao IED não pode ser absoluta. Ela tem de se conformar a princípios basilares tributários como econômicos, preservando contribuintes, mercado e, ao fim, o próprio País. 


\section{CAPÍTULO I - TRIBUTAÇÃO INTERNACIONAL E ORDEM JURÍDICA PÓS-MODERNA}

\section{I.1 TRIBUTAÇÃO INTERNACIONAL NA PÓS-MODERNIDADE}

\section{I.1.1 Tributação no Estado do século XXI}

O Estado contemporâneo vive confrontado por várias incertezas. Em diversos campos de atuação estatal surgem enigmas ainda não totalmente decifrados que dificultam o entendimento sobre o atual estado de coisas e acarretam a própria descrença do Estado. Vive-se um ambiente de céleres mudanças, caracterizado, em sua essência, pela dúvida; pela complexidade crescente das sociedades; pela desconstrução do racional, do sistematizado e do conteúdo; pela valorização do pontual, fragmentário, instável, estético; que se passou a denominar pós-modernidade. ${ }^{1}$

Embora enseje opiniões variadas quanto ao seu alcance, pós-modernidade, para os limites deste trabalho, significa reconhecer que o mundo atravessa uma fase de indefinições que se espraia por diversas áreas, interessando-se, especificamente, sobre os conflitos que exsurgem da tributação e, ainda mais pontualmente, no campo da tributação da renda.

Poder-se-ia trabalhar apenas com a mais marcante de suas características - a globalização -, ${ }^{2}$ mas prefere-se trabalhar com a pós-modernidade como sinônimo de algo ainda indefinido, a ser construído e exatamente por isso, com potencial para mudança adequado à busca de maior competitividade internacional, pontualmente quanto à tributação da renda.

\footnotetext{
${ }^{1}$ DINIZ, Antônio Carlos. Pós-modernismo. In: BARRETTO, Vicente de Paulo (Coord.). Dicionário de Filosofia do Direito. São Leopoldo-RS: Unisinos, 2006, pp.647-650.

${ }^{2}$ A globalização continua como fenômeno relevante, merecedor, inclusive, de um tópico específico nesta tesa (v. I.1.1.1). Transcreve-se, nesse sentido, o pensamento de Paulo Borba Casella: "Não mais se fale em globalização, enquanto tal - ninguém mais agüenta a repetição de tais discursos --, mas cabe perquirir quais sejam os meios e modos de fazer que esta opere de modo adequado. Se isto for possível. Mas, como não pode a globalização ser evitada, é melhor que esta funcione, do modo menos danoso para a vida e a dignidade humana, para a acultura, para o meio ambiente e para a continuidade da vida inteligente no planeta." V. CASELLA, Paulo Borba. BRIC: Brasil, Rússia, Índia, China e África do Sul: uma perspectiva de cooperação internacional. São Paulo:Atlas, 2011, p.8.
} 
O novo cenário do mundo retrata mudanças ainda em curso. A multipolaridade ainda está em construção. ${ }^{3}$ Logo, as condições típicas do momento - aqui chamadas pósmodernidade - indicam a oportunidade da construção de um futuro que pode ser planejado agora para a obtenção de resultados calculados por parte dos Estados. O Brasil deve aprender com a experiência histórica, mas livrar-se de comportamentos atávicos se desejar ascender na ordem internacional. Para tanto, pretende-se contribuir com a averiguação da coerência sistêmica e finalística das normas brasileiras sobre o imposto de renda, no sentido de atestar sua competitividade e atração ao IED, com o fim precípuo do desenvolvimento.

Nessa esteira, Luís Roberto Barroso identifica alguns dos desafios impostos pelo cenário atual ao Estado do século XXI nos planos:

(i) sócio-econômico: marcado pelos rápidos avanços tecnológicos e científicos, bioética, desemprego, informalidade;

(ii) político: marcado pelo desenho de um novo Estado, impessoal, preocupado em garantir concorrência e lucros;

(iii) internacional: desprestígio da noção tradicional de soberania e blocos políticos e econômicos. A livre circulação de fatores de produção e até do capital confirmam a globalização como realidade marcante do novo século;

(iv) jurídico: nem liberdade individual (Estado Liberal) e nem intervenção estatal (Welfare State), mas governabilidade. ${ }^{4}$

A tributação, por si só, representa um vasto complexo a ser enfrentado pelo Estado pós-moderno. Sob o prisma internacional, a desmaterialização dos critérios de conexão, o conceito de estabelecimento permanente, a dicotomia entre fonte e residência, o direito de integração, as liberdades de circulação e a fuga de receitas são alguns dos desafios ao Estado do sec. XXI. No direito interno não é diferente, pois há a necessidade de bem definir o papel do Estado, já que o desempenho de suas funções dependerá, em larga escala, da tributação. O resultado das decisões implantadas pelo Estado na órbita tributária interna e internacional definirá sobre sua inserção na ordem internacional no que tange à tributação.

\footnotetext{
${ }^{3}$ Cf. P. B. Casella,. BRIC: Brasil, Rússia, Índia, China e África do Sul: uma perspectiva de cooperação internacional, pp.5-6.

${ }^{4}$ BARROSO, Luís Roberto. Interpretação e aplicação da Constituição: fundamentos de uma dogmática constitucional transformadora, 6. ed. São Paulo: Saraiva, 2004, pp. 304-306.
} 
Sob perspectiva evolutiva mais recente, o Estado contemporâneo pode ser visto como Estado Fiscal, cuja característica marcante vincula o desempenho da atividade financeira do Estado ${ }^{5}$ aos tributos - principal fonte de ingresso de receitas públicas. Há uma relação de dependência do Estado ao tributo como a chave para a execução de seus objetivos e políticas. ${ }^{6}$ Portanto, torna-se cada vez mais importante o atributo da eficiência na gestão pública. Deve-se arrecadar o necessário para a boa governança e evitar o desperdício de receitas que reduzem o bem-estar da sociedade.

O Brasil, aparentemente de forma injustificada, mantém carga tributária bastante elevada, principalmente se comparada a de seus concorrentes diretos. ${ }^{7}$ A implantação das políticas públicas depende da arrecadação, mas exige, igualmente, dispêndios rigorosamente controlados. A falta de uma política clara de despesas torna vilão o tributo perante a sociedade. ${ }^{8}$ Ademais, o crescimento das despesas públicas pressiona os ingressos públicos, que, a despeito de quebrarem recordes de arrecadação, são sempre insuficientes. ${ }^{9}$

Sobre este ponto, identificam-se duas facetas da tributação: fiscalidade que representa o carrear de recursos privados para o erário; e extrafiscalidade, como resultado de comportamentos do agente econômico estimulados por manejos econômico-financeiros do Estado. ${ }^{10}$

Deve, pois, o Estado esforçar-se por calibrar bem suas políticas fiscal e extrafiscal, já que ambas impactam na atração de IED e podem estimular o desenvolvimento. $\mathrm{O}$

\footnotetext{
${ }^{5}$ Ricardo Lobo Torres define a atividade financeira do Estado como "conjunto de ações do Estado para obtenção da receita e a realização dos gastos para o atendimento das necessidades públicas." V. Ricardo Lobo Torres, Curso de direito Financeiro e Tributário, 16 ed., Rio de Janeiro: Renovar, 2009, p. 3.

${ }^{6}$ É o que André Elali chama de estadualidade fiscal, que se pode definir como a cisão entre Estado e Economia, permanecendo a capacidade de financiamento daquele pela via do tributo incidente sobre as receitas produtivas da última. Cf. André Elali, Incentivos fiscais internacionais - concorrência fiscal, mobilidade financeira e crise do Estado. São Paulo: Quartier Latin, 2010, p.103.

${ }^{7}$ Segundo a Receita Federal do Brasil, a carga tributária brasileira em 2009 foi de 33,14\% do PIB. Em 2010 a carga subiu para 33,56\%, conforme o Demonstrativo "Carga Tributária no Brasil 2010”, p.1. Disponível em: http://www.receita.fazenda.gov.br/Publico/estudoTributarios/estatisticas/CTB2010.pdf. Acesso em 17 out 2011. Quando comparado a países em desenvolvimento, a carga brasileira é bastante superior. Em 2009, o Chile apresentou carga tributária de apenas 18,02\%; o México de 17,5\%; a Turquia de 24,6\%, segundo dados da OCDE disponíveis em: http://www.oecd-ilibrary.org/taxation/total-tax-revenue_20758510-table2. Acesso em 17 out 2011. O Tribunal de Contas da União, em sua versão simplificada das Contas do Governo, também aponta o Brasil como o País de tributação mais elevada dentre os BRIC. Segundo o TCU, em 2009, a Rússia apresentou carga tributária de 23,73\%; a China de 20,57\%; e a Índia de apenas 12,16\%. Dados disponíveis em: http://portal2.tcu.gov.br/portal/pls/portal/docs/2056554.PDF. Acesso em 17 out 2011.

${ }^{8} \mathrm{O}$ total dos gastos públicos cresceu $24 \%$ em 2010 em comparação a 2009. Dados extraídos das Demonstrações Contábeis da União, 2010, p.9. Disponível em: http://www.tesouro.fazenda.gov.br/contabilidade_governamental/download/BGU_sintetico.pdf. Acesso em 17 out 2011.

${ }^{9}$ Dados divulgados na Prestação de Contas da Presidência da República 2010 demonstram um crescimento real da arrecadação federal de $10,40 \%$ em comparação a 2009, item 2.11.. Disponível em : http://www.cgu.gov.br/Publicacoes/PrestacaoContasPresidente/2010/Arquivos/2.11.pdf . Acesso em 17 out 2011.

${ }^{10}$ Cf. A. Elali, Incentivos fiscais internacionais, pp. 105-106.
} 
excesso de fiscalidade está confrontado pela própria ordem pós-moderna, de modo que alta exação não atrai o capital estrangeiro e ainda provoca a fuga de capital interno. Já a extrafiscalidade, se mal implantada, pode malferir valores constitucionalmente garantidos como justiça e igualdade, além de encontrar regulação em organismos internacionais, com destaque para a OMC, que, por meio de seu Órgão de Solução de Controvérsias, poderá decidir sobre auxílios fiscais considerados nocivos ao comércio internacional.

Outro aspecto a merecer destaque em matéria de tributação no Estado do século XXI, diz com o direito de integração. É vero que a soberania está em cheque após a flexibilização das fronteiras, mas é dela que deriva o poder de tributar dos Estados, daí resultando um paradoxo de difícil solução. No exercício dessa soberania tributária, cada vez mais os Estados necessitam de cooperação internacional.

O caso brasileiro torna-se relevante segundo as auspiciosas sugestões de Paulo Borba Casella, no sentido de que "ante o imperativo da busca de inserção internacional, no mundo de hoje, a perspectiva BRIC de cooperação pode significar mutação de alcance mundial". A tal resultado não se poderá chegar, contudo, sem a busca efetiva da construção de um modelo de relação sem precedentes, em que cada país - Brasil. Rússia, Índia e China, em defesa de seus interesses, aja de forma multilateral. ${ }^{11}$

\section{I.1.1.1 Globalização}

Vive-se a era global. Comércio e investimentos são estimulados além-fronteiras, propulsados pelo célere avanço tecnológico que encurtou o planeta. Sob este prisma, os sistemas tributários domésticos passaram a interagir de forma mais intensa, de modo que políticas tributárias adotadas por um país impactam, por vezes sensivelmente, economias outras ao redor do globo.

A mobilidade cada vez maior dos fatores de produção representa ameaça real às bases de tributação da renda dos Estados. Sobre este tema, resta, portanto, indagar se a sistemática corrente de tributação da renda, tanto pela via da imposição quanto da renúncia, estimula a competitividade brasileira na realidade econômica internacional de nossos dias.

${ }^{11}$ CASELlA, Paulo Borba. BRIC: Brasil, Rússia, Índia, China e África do Sul: uma perspectiva de cooperação internacional. São Paulo:Atlas, 2011, pp. 6-7. 
O contexto do comércio internacional, em meados do século passado, era radicalmente distinto do presente. Foi aquele contexto que deu origem às regras de tributação internacional ainda hoje aplicadas. ${ }^{12}$ Fato é que a globalização veio alterar radicalmente o comércio, a economia, a política e a ordem jurídica dos Estados, colocando em xeque a sistemática de tributação em questão.

Raúl Granillo Ocampo sustenta que o fenômeno global não é recente, tendo havido uma primeira etapa do processo no período $1870-1914 .{ }^{13}$ Naquela fase, o avanço tecnológico reduziu o custo dos transportes e estimulou o fluxo de bens, serviços, capitais e pessoas. O motor a combustão, o telefone, a lâmpada elétrica e a máquina datilográfica são apenas alguns dos exemplos de inovações que permitiram maior intercâmbio nas relações humanas.

Um segundo período teria ocorrido após a $2^{\text {a }}$ Guerra, com a retomada dos fluxos de comércio internacionais. Entretanto, somente em 1980 teve início a etapa marcada pela tecnologia nas comunicações e nos transportes, que levou o comércio a níveis jamais dantes vistos. Nesta última fase, a revolução tecnológica, o crescimento e a mobilidade da população mundial, o enfraquecimento do poder político nacional, a queda do comunismo e a universalização dos direitos humanos destacam-se como fatores potencializadores do fenômeno global. ${ }^{14}$

Reuven Avi-Yonah distingue a atual globalização daquela iniciada em fins do séc. XIX pela muito maior mobilidade do capital. Na primeira, a mobilidade da mão-de-obra seria pelo menos equivalente à do capital. Fato é que o capital, altamente móvel, relaciona-se com a concorrência tributária internacional de modo a reduzir as receitas provenientes da tributação da renda individual e corporativa.. Tal fato leva os Estados democráticos a extremas dificuldades em manter os benefícios da seguridade social ao

\footnotetext{
${ }^{12}$ Cf. C. E. McLure Jr., Globalization, tax rules and national sovereignty, pp.333-334.

${ }^{13}$ OCAMPO, Raúl Granillo. Direito internacional público da integração. Rio de Janeiro, Elsevier, 2009, pp. 9-10.

${ }^{14}$ Cf. R. G. OCAMPO, Direito internacional público da integração, pp. 11-21. Em sentido diverso, Fernando Scaff entende que a globalização tem fomentado quase exclusivamente a mobilidade do capital, mas não de pessoas e bens, em vista da presença ainda intensa de barreiras alfandegárias e de imigração. A exceção seria a UUEE, pois o assunto não tem merecido acolhida na formação de blocos comunitários como MERCOSUL e Nafta. V. SCAFF, Fernando Facury. O direito tributário das futuras gerações. In: MARTINS, Ives Gandra da Silva (coord.), Tributação na internet. São Paulo: Centro de Extensão Universitária/Revista dos Tribunais, 2001( Pesquisas tributárias: nova série 7), p. 403.
} 
mesmo tempo em que perdem receitas. A limitação da globalização seria, assim, uma alternativa para manutenção do índice de bem-estar mundial. ${ }^{15}$

Nos dizeres de César Novoa, a globalização seria

“el proceso de mundialización econômica provocado no solo por condicionamientos de tipo político como la caída de los regímenes del Este y el predomínio del ideário liberal, sino también por otros factores inherentes a la actual etapa histórica como la ampliación de los mercados propiciada por la libre circulación del capital y su creciente institucionalización (...) y a la difusión de las nuevas formas de comunicación, em especial Internet, así como la integración de los mercados em espacios econômicos que superan los limites territoriales del Estado." 16

Dessa definição extrai-se que a globalização transcende aos limites jurisdicionais de um Estado, enfraquecendo seu poder político. E mais, que representa um enorme desafio (ou antagonismo?) à tributação, pois esta decorre do exercício da soberania tributária de um Estado, que tanto deverá ser politicamente mais forte, quanto maiores os ingressos públicos de que dotar seus cofres.

A questão se torna ainda mais delicada se se volver o foco para a tributação internacional, pois, como assevera Doernberg, o estudo da tributação internacional é o estudo da coordenação da autoridade tributária de países soberanos. ${ }^{17}$ Isto porque coordenar, no cenário internacional, políticas tributárias idênticas e não complementares pode ser impossível. Os Estados pretendem preservar as rendas que se lhes podem escapar com a intensa mobilidade dos fatores de produção.

Do mesmo modo, a globalização alterou sobremaneira as características das relações comerciais e econômicas, enquanto que as regras de tributação são as mesmas de cinco décadas. Neste sentido, o fenômeno global pode ser exemplificado pelo comércio

\footnotetext{
${ }^{15}$ AVI-YONAH, Reuven S. Globalization, tax competition and the fiscal crisis of the welfare state. Harvard Law School, Working Paper nº4, 2000. Disponível em: http://ssrn.com/abstract=208748. Acesso em: 05 nov 2011.

${ }^{16}$ Cf. C. G. NOVOA. Reflexiones sobre La influencia de La globalización en los princípios tributarios. In: TÕRRES, Heleno Taveira. (coord.), Direito Tributário Internacional Aplicado. São Paulo: Quartier Latin, 2003. p. 34.

${ }^{17}$ No original: "The study of international tax is the study of coordinating the tax authority of sovereign countries." DOERNBERG, Richard L. International Taxation in a Nutshell. $5^{\text {th }}$ ed. St Paul, Minnesota:West Group, 2001, p. 3.
} 
eletrônico, que desafia as atuais regras tributárias e limita o poder de tributar dos Estados. Uma visão geral da economia mundial atual assim se poderia resumir:

(i) comércio internacional substancialmente sobre intangíveis e serviços;

(ii) comércio internacional praticado entre partes relacionadas;

(iii) presença física não é relevante com o conteúdo digital;

(iv) intangíveis são vitais para a moderna corporation;

(v) telecomunicações são providas por empresas particulares e cruzam fronteiras;

(vi) capital apresenta alta mobilidade internacional;

(vii) dificuldade em distinguir juros de dividendos por causa dos derivativos financeiros;

(viii) residência de uma empresa pode ser ambígua ou modificada facilmente;

(ix) tax havens impõem ameaça às receitas de um Estado, bem como à equidade $\mathrm{e}$ neutralidade do sistema de um Estado;

(x) EUA continuam relevantes, mas outras forças passaram a disputar a liderança política e econômica do planeta, como a China e União Européia. ${ }^{18}$

Através da expansão do comércio e do investimento, migração de mão-de-obra e transferência de tecnologia, a globalização transforma as diversas economias nacionais em uma única economia mundial.

Os efeitos da globalização na tributação internacional já podem ser constatados e sugerem, aos Estados que desejarem ser competitivos, a criação de um ambiente propício aos fluxos de investimento internacional, que cresceram cerca de dez vezes desde a década de 90 até os dias atuais. Simultaneamente, percebe-se a significativa redução da tributação da renda corporativa nos países da OCDE, onde a alíquota média foi reduzida de $38 \%$ para $27 \%$,e na UUEE, onde a queda, no mesmo período, foi de $38 \%$ para $24 \% .^{19}$

Pode-se afirmar, portanto, que a globalização produz efeitos diretos sobre a economia e exige planejamento dos Estados que se pretendam competitivos. Através da expansão do comércio e do investimento, migração de mão-de-obra e transferência de

\footnotetext{
${ }^{18}$ Cf. C. E. McLure Jr, Globalization, tax rules and national sovereignty, p.334.

${ }^{19}$ EDWARDS, Chris; MITCHELL, Daniel J. Global tax revolution: the rise of tax competition and the battle to defend it. Washington, D.C.: CATO Institute, 2008, p.2.
} 
tecnologia, transformam-se as diversas economias nacionais em uma única economia mundial. $^{20}$

\section{I.1.1.2 Integração econômica e livre mobilidade de bens, pessoas, serviços e capitais}

As dúvidas e incertezas dos tempos atuais decerto representam uma justificativa para maior competitividade no cenário internacional a que os Estados aspiram. Como uma política para o desenvolvimento econômico, os Estados passam a interagir de forma singular naquilo que se pode definir como espaços integrados.

$\mathrm{Na}$ verdade, a integração econômica é a resultante de uma opção voluntária, consensual, em que os Estados visam a eliminar a todo o tipo de discriminação sobre nacionais de outros Estados, membros do mesmo espaço integrado, o que, em princípio, não se estende a terceiros países extrabloco. ${ }^{21}$

Inobstante sejam diversas as causas que levam um Estado à integração, certamente que o faz pela crença de que o bloco poderá tornar mais próspero seu ambiente econômico, político, social e institucional. Podem motivar a adesão de determinado Estado ao processo integrativo: poder de negociação mais abrangente que de um Estado isolado; melhor alocação de recursos econômicos que geram maior eficiência e ganhos de competitividade; garantia de mercado em eventuais tempos de crise protecionista tendo por meta evitar o isolamento internacional. ${ }^{22}$

Comumente, o processo integrativo apresenta dimensão internacional - OMC, OCDE -, ou regional, tais como UUEE, Nafta e MERCOSUL. Este último modelo apresenta classificação de acordo com o aprofundamento das relações entre os membros e a institucionalização alcançada no seio do bloco, que, em síntese, seria: ${ }^{23}$

(i) Zona de Livre Comércio: comércio livre entre os integrantes, mas protegido, individualmente, de acordo com cada política nacional perante terceiros;

\footnotetext{
${ }^{20} \mathrm{Cf}$. C. Edwards e D.J. Mitchell, Global tax revolution: the rise of tax competition and the battle to defend it., p.2.

${ }^{21}$ Cf. R.G. Ocampo, Direito internacional público da integração, pp. 21-23.

${ }^{22}$ Cf. R.G. Ocampo, Direito internacional público da integração, pp.24-25.

${ }^{23}$ Ocampo registra que haveria uma sexta modalidade: a zona de preferência ou de intercâmbio preferencial. Seria esta a primeira etapa de integração, cujas contornos não chegam a eliminar as tarifas alfandegárias entre os participantes, mas a atribuir um tratamento preferencial, mais vantajoso economicamente, às suas produções. V. R. G. Ocampo, Direito internacional público da integração, pp. 28-29.
} 
(ii) União Aduaneira: tarifa externa comum a todo o território aduaneiro que corresponde à soma dos territórios dos membros;

(iii) Mercado Comum: agrega sobre as etapas anteriores a liberdade de circulação de mercadorias, pessoas, serviços e capitais;

(iv) União Econômica: identificada pelas políticas econômicas comuns: monetária, fiscal, industrial, agrícola etc.;

(v) Integração Total ou União Política: último estágio de integração, prevê a adoção de uma política unificada para atuação nos diversos segmentos sociais, políticos e econômicos.

A partir de um mercado comum já se pode identificar a presença das liberdades fundamentais (ou liberdades de mercado). $\mathrm{Na}$ verdade, o processo de integração avança desde o favorecimento, inicialmente, tarifário, para a coordenação, a harmonização ${ }^{24}$ e quiçá a uniformização tributária. ${ }^{25}$ A liberdade de circulação de bens, serviços, pessoas e capitais impõe restrições à conduta dos Estados-membros que não podem discriminar trabalhadores, cidadãos, produtos, serviços ou investimentos por sua origem. De fato, o país importador deve conceder, a qualquer dos fatores de produção importados, o mesmo tratamento que oferta aos seus próprios.

Em matéria de tributação, não poderá haver ônus superior por conta da procedência do produto ou mesmo reduzir as possibilidade de dedução do Imposto de Renda a pessoas físicas ou jurídicas cuja origem seja outro membro do bloco.

\footnotetext{
${ }^{24}$ Coordenação e harmonização são diferentes estágios de aproximação da legislação tributária. Naquela, há fixação de políticas para consecução de determinado objetivo comum aos participantes do bloco. Já nesta última, prepondera o interesse em reduzir as diferenças legislativas, buscando a eliminação das controvérsias tributárias para, em último grau, tornar o bloco mais competitivo e atraente ao investidor externo. $\mathrm{V}$. SCHOUERI, Luís Eduardo. Tratados e convenções internacionais sobre tributação. In: COSTA, Alcides Jorge; SCHOUERI, Luís Eduardo e BONILHA, Paulo Celso Bergstrom (coord.), Direito Tributário Atual 17. São Paulo: Dialética, 2003. p. 24

${ }^{25}$ SCHOUERI, Luís Eduardo. Tratados e convenções internacionais sobre tributação. In: COSTA, A. J.; SCHOUERI, L. E. e BONILHA, P .C. B.(coord.), Direito Tributário Atual 17. São Paulo: Dialética, 2003. p.24.
} 
Sobre este ponto, vale ressaltar a questão da ampla liberdade de capitais prevista no art. 56 do Tratado da União Européia - TUE. ${ }^{26}$ Embora as demais liberdades alcancem tão-só membros da UUEE, a liberdade de capitais deveria ser aplicada, irrestritamente, a membros e a terceiros países. A CEJ, contudo, vem construindo interpretação conservadora sobre o tema, priorizando as restrições e salvaguardas elencadas nos artigos 57 a 60 do TUE, atuais artigos 64 a 66 do TFUE. $^{27}$

Com efeito, a integração econômica traz um complicador à tributação, que antes submetida à ordem interna e à internacional, agora vê-se compelida à observância de um direito comunitário, supra-estatal. Tomando o exemplo da UUEE, onde o incipiente direito já se solidificou com o auxílio dos organismos próprios da União, especialmente da Corte Européia de Justiça - CEJ, pode-se afirmar que o investidor europeu encontra larga liberdade de escolha quanto à destinação de seu capital. A isso se alia um bom grau de previsibilidade de retorno, já que é possível comparar os diversos sistemas tributários dos integrantes do bloco, antes da tomada de decisão. ${ }^{28}$

Com o avançar da globalização e o encurtar das distâncias, o mundo ruma para um maior intercâmbio de investimentos e busca por fatores de produção tanto intrablocos como nas relações entre os membros integrados e países terceiros, o que, decerto, já obriga os Estados a observarem o cenário global a fim de moldarem suas ordens tributárias como ferramentas que lhe impulsionem ao desenvolvimento. Devem, pois, fazer isso com acerto e celeridade, a fim de não perderem a oportunidade para outros países que estão, do mesmo modo, competindo nesse tema.

\footnotetext{
${ }^{26}$ TFUE, Art. 63 (ex-artigo 56 TUE). No âmbito das disposições do presente capítulo, são proibidas todas as restrições aos movimentos de capitais entre Estados-Membros e entre Estados-Membros e países terceiros. (grifo nosso)

${ }^{27}$ As restrições à liberalização de capitais em operações com países terceiros podem ser observadas em casos decididos mais recentemente, dentre os quais: C-101/05 (A); C-157/05 (Holböck); C-201/05 (Test Claimants CFC); C-205/06 (Comissão/Áustria); e C-249/06 (Comissão/Suécia). A CEJ tem atestado a conformidade, ao direito comunitário, de restrições variadas à liberalização erga omnes, resumidamente aqui aduzidas:

(i) restrição imposta pelo direito doméstico, vigente desde 31/12/93, envolvendo investimento direto;

(ii) restrição com vistas a preservar a eficácia do controle fiscal de um Estado-Membro, não pela diferença da origem dos dividendos, se intra ou extra-UE, mas pela diferença de objetivos e de contexto jurídico em que se insere o fluxo de capitais; e

(iii) restrição decorrente da inércia de um Estado-Membro em eliminar incompatibilidades entre um acordo firmado com país estranho ao bloco antes de sua adesão à UE e suas obrigações decorrentes do direito comunitário.

Portanto, em suas últimas decisões sobre liberalização de capitais envolvendo terceiros países, a CEJ abriu campo a possibilidades de justificação a restrições impostas pelo direito doméstico de um Estado-Membro, afastando-se da direta e irrestrita liberdade prevista no art.. 56. Para maiores detalhes acerca desse tema, v. ALMEIDA, Carlos Otávio Ferreira de. O ingresso de dividendos na UE - Precedentes da Corte Européia de Justiça quanto à liberalização de capitais. In COSTA, Alcides J., SCHOUERI, L.E, BONILHA P C. B e ZILVETI, F. A.. (Coord.) Direito Tributário Atual, 24. São Paulo: Dialética, 2010, p.221-239.

${ }^{28}$ Cf. L.E. Schoueri, Tratados e convenções internacionais sobre tributação, p. 24.
} 


\section{I.1.1.3 A importância crescente da tributação da renda no contexto pós-moderno}

Um dos principais desafios enfrentados pelo Estado neste começo de século é a questão da fiscalidade. Os efeitos da crise iniciada em 2008 ainda se fazem sentir ao redor do globo. Na Europa, Grécia, Irlanda, Portugal, Espanha e, mais recentemente, Itália encontram-se em sérias dificuldades orçamentárias. Até os EUA, ainda a maior economia do mundo, atravessam uma de suas mais duras crises. Em face da atual conjuntura, indagase sobre a melhor alternativa para a consecução de superávits orçamentários.

O aumento de tributo é modelo ultrapassado enquanto solução para todos os males, autêntica panacéia. Na busca de soluções, os Estados esbarram na liberalização e na globalização como obstáculos de difícil transposição, pois acarretam a flexibilização das fronteiras e a perda das bases de tributação mais sujeitas à mobilidade (race to the bottom). Assim, diversos sistemas tributários passaram a onerar mais fortemente o trabalho e o consumo em detrimento do capital, cuja refração à alta tributação se relaciona, diretamente, com sua maior mobilidade.

A discussão acerca da adoção de uma política fiscal mais adequada quanto às bases de tributação está além do escopo deste trabalho. Entretanto, a renda se torna cada vez mais importante como fonte de ingressos públicos num ambiente em que os efeitos de transbordamento (spillover effects) de um sistema tributário impactam, cada vez mais significativamente, mercados além-fronteiras.

Nesse contexto, a questão da preservação de receitas é importante ao Estado pósmoderno, que deverá desenvolver políticas de estímulo, confiança e transparência ao investidor que se pretenda atrair, assim como ao que já esteja presente em sua jurisdição. No que toca ao não-residente, a tributação na fonte deve compensar outros fatores decisivos de alocação do investimento, inter alia, infra-estrutura, segurança jurídica e mãode-obra qualificada; já o residente deve se sentir encorajado a permanecer malgrado a sistemática adotada quanto à tributação da renda - territorial ou universal. ${ }^{29}$

Entretanto, somente preservar os níveis de arrecadação não basta. O Estado precisa ampliar suas receitas, pois estas, necessariamente, são pressionadas por despesas crescentes a cada ano, que refletem os efeitos causados pela inflação, crescimento

${ }^{29}$ OCDE. Taxing profits in a global economy- domestic and international issues, OECD, Paris, 1991, ISBN 92-64-13596-0, p. 11. 
demográfico, ampliação de aposentadorias e pensões, dentre outros. Eis uma tarefa árida. Afinal, aumentar o ônus fiscal em um ambiente de competição tributária pode levar ao déficit público. ${ }^{30}$

Há uma preocupação geral dos Estados quanto à tributação da renda corporativa, pois distorce a alocação do capital internacional; apresenta grande complexidade; afeta a neutralidade e torna o ambiente hostil pela coexistência de diferentes regimes de tributação com redução de barreiras não-tarifárias. ${ }^{31}$

Por outro lado, a tributação de indivíduos também apresenta percalços. Segundo Vito Tanzi, houve grande crescimento das rendas forâneas de indivíduos nos últimos anos. Tais rendas são tanto mais passíveis de sonegação quanto menor a capacidade de atuação da administração tributária dos Estados. Outro complicador é a existência de tax havens, que, facilmente acessíveis pelos avanços tecnológicos, ofertam guarida aos indivíduos. ${ }^{32}$

Em síntese, o papel do Estado contemporâneo, quanto à tributação da renda, pode volver os olhos ao passado recente, quando reduziu o intervencionismo típico do Welfare State reconfigurando-se como Estado Subsidiário, que, em matéria fiscal, se poderia denominar Estado Fiscal. A tônica do novo formato é arrecadar com eficiência e igualdade. Logo, austeridade e parcimônia na coleção fiscal para bem distribuir as receitas derivadas da sociedade é crucial para um Estado prosperar na pós-modernidade.

Nesta esteira, o imposto de renda pode ser visto como importante ferramenta para promover redução de desigualdades de modo eficiente. No caso brasileiro, o contraste entre o bom desempenho da economia e os altos índices de concentração da renda tornam essa análise ainda mais premente. ${ }^{33}$

Fato é que a tributação da renda tem alcance amplo, atingindo residentes e nãoresidentes na jurisdição. Logo, deve se traduzir por regras simples, transparentes, que busquem promover objetivos previstos na Constituição Federal. Assim, para garantir o

${ }^{30}$ TANZI, Vito. Globalization, tax competition by the future of tax systems. In: UCKMAR, Victor (org.). Corso di diritto tributario internazionale, 2 ed., Padova: CEDAM, 2002, p.31.

${ }^{31}$ Cf. OCDE. Taxing profits in a global economy-domestic and international issues, p.13.

${ }^{32} \mathrm{Cf}$. V. Tanzi, Globalization, tax competition by the future of tax systems, pp. 27-28.

${ }^{33}$ Conquanto esteja além do escopo desta tese, a análise econômica do direito pode proporcionar resultados interessantes quanto à eficiência de um sistema tributário, por meio da aplicação de ferramental tipicamente econômico. A economia pode ser utilizada como padrão avaliativo para o direito e as políticas públicas, valendo-se da eficiência. Afinal, melhor concretizar objetivos de uma determinada política pública a custos menores do que a custos maiores. O Estado, portanto, na definição de suas políticas públicas está atrelado ao critério da eficiência. As empresas, por seu turno, ligam-se ao lucro. Por conseguinte, um bom sistema jurídico deve promover a lucratividade das empresas e o bem-estar dos jurisdicionados, de modo que os que buscam lucro devem beneficiar o público. Outro objetivo das políticas públicas é promover igualdade. Para isso é preciso distribuir riqueza. Para maior investida sobre análise econômica do direito, v. COOTER, Robert; ULLEN, Thomas. Direito e economia, 5. ed. Porto Alegre: Bookman, 2010. 
desenvolvimento nacional (art. $3^{\circ}$, II, CF), é legítima a atuação no sentido de atrair capital. Todavia, o cenário de competição internacional por riquezas não deve, de plano, sobreporse a outros dispositivos constitucionais que informam a tributação da renda, como legalidade, igualdade, não-confisco (arts. 150, I, II e IV, CF), além de outros sob a ordem econômica, como livre-iniciativa e livre-concorrência (art. 170, caput e I).

Segundo Tipke e Lang, o imposto de renda apresenta elevado valor de equidade cuja concreção depende que a generalidade das pessoas e a universalidade das rendas sujeitem-se à sua imposição. Na prática, por ser um imposto mais facilmente perceptível, sofre resistência por parte dos contribuintes, tornando-se administrativamente custoso. Uma das formas de resistência é o lobby, cujo fim está em reduzir o ônus tributário, afetando a qualidade de justiça do imposto de renda. ${ }^{34}$

Por conseguinte, o Estado pós-moderno deve atentar para a coerência dos institutos da tributação da renda com o ordenamento jurídico. Preciso observar se tais institutos servem ao fim que lhes deu causa. Objetivos estritamente arrecadatórios devem ser cotejados com objetivos de atração de capital, pois, conquanto não sejam excludentes, a convivência entre eles exige harmonia necessária a que o Estado contemporâneo possa buscar receitas sem prejuízo de sua atratividade aos investidores.

\section{I.1.2 Tributação universal e tributação territorial}

A complexidade do Direito Tributário Internacional reside no estudo da tributação que se impõe sobre fluxos internacionais de renda, envolvendo mais de um Estado soberano. Nesses casos, nem sempre é fácil identificar o(s) ente(s) legitimado(s) a tributar tais fluxos de rendimentos.

O Estado, enquanto entidade individualizada na ordem internacional, apresenta-se dotado de território, povo e governo independente. ${ }^{35}$ É sobre seu território que o Estado, com exclusividade, exerce sua jurisdição administrativa, legislativa e jurisdicional, ${ }^{36}$ habilitando-se, dentre outras tarefas, à cobrança de tributos para viabilizar o exercício de

\footnotetext{
${ }^{34}$ TIPKE, Klaus et LANG, Joachim. Direito tributário (Steuerrecht), v. 1. Tradução: Luiz Dória Furquim. Porto Alegre: Sergio Antonio Fabris, 2008, pp. 448 e 451.

35 Cf. F. Rezek, Direito internacional público - curso elementar, p.165. Há, ainda, outros elementos constitutivos do Estado, como finalidade - o Estado tem o dever de prover o bem comum - e capacidade de relacionar-se com outros Estados, conforme o art. $1^{\circ}$ da Convenção Pan-americana sobre Direitos e Deveres dos Estados, de 1933 (Dec. 1.570/47). Neste sentido,v. V. O. Mazuolli, Curso de direito internacional público, São Paulo: Revista dos Tribunais, 2006, p.178.

${ }^{36}$ Cf. F. Rezek, Direito internacional público - curso elementar, pp. 165-166.
} 
suas funções. Se acaso desejasse instituir, unilateralmente, cobrança de tributos em território alheio, o Estado incorreria em violação de direito internacional público.

Por outro lado, o Estado encontra-se livre para legislar em matéria tributária, ainda que sobre fatos, bens, pessoas que estejam fora de seus domínios territoriais, desde que apresentem um elemento de conexão (genuine link) com seu território. ${ }^{37}$ É o que se denomina territorialidade material e que legitima o Estado, por meio da atividade legislativa in abstrato, no âmbito da incidência (domaine de validité, Geltungsraum), a exercer jurisdiction to prescribe (taxes). ${ }^{38}$

Diferente da possibilidade de dispor sobre normas em abstrato, não se franqueia ao Estado a mesma liberdade quanto à aplicação de sua norma tributária de forma coercitiva em território estranho. Isso em razão de a territorialidade formal não lhe permitir o exercício de jurisdiction to enforce. Em outro giro, a ação de autoridades fiscais ou judiciais, no caso concreto, com vistas a garantir a satisfação do crédito tributário, não pode ir além-fronteiras, já que a eficácia das normas permanece circunscrita pelos limites territoriais do Estado (sphère d'efficacité, Wirkungsraum). ${ }^{39}$

A discussão acerca da possibilidade de aplicação da territorialidade material ou formal a situações ocorridas fora dos limites territoriais de um Estado remonta a 1926, ocasião dos fatos consagrados em Lotus, caso decidido pela Corte Permanente Internacional de Justiça, em 1927, no sentido da possibilidade da norma doméstica alcançar situações ultraterritoriais. ${ }^{40}$

Em Lotus, houve um abalroamento entre um navio de bandeira francesa (Lotus) e outro de bandeira turca (Boz-Kourt) em águas internacionais, do qual resultou a morte de oito turcos. Ambos os comandantes foram condenados por homicídio culposo pela Turquia, o que causou a indignação da França e a submissão do caso à CPIJ. A Corte se pronunciou no sentido de que a Turquia não se opunha a qualquer regra de direito internacional. Este não consentia com o exercício de jurisdição em território alheio (jurisidction to enforce ou territorialidade formal), mas franqueava ampla liberdade para

\footnotetext{
${ }^{37}$ Cf. H. T. TÔRRES, Princípio da Territorialidade e tributação de não-residentes no Brasil. Prestações de serviços no exterior. Fonte de produção e fonte de pagamento. In: TÔRRES, Heleno Taveira. (coord.), Direito Tributário Internacional Aplicado. São Paulo: Quartier Latin, 2003. p.76.

${ }^{38}$ Cf. A. Xavier, Direito tributário internacional do Brasil. 6. ed , pp. 6-7.

39 Alberto Xavier também destaca que a integração econômica tende a estabelecer cooperação para a execução coercitiva de créditos tributários de um Estado em território de outro. A Convenção Nórdica, por exemplo, já aceita que diligências fiscais de um signatário se dêem em território de outro. Direito tributário internacional do Brasil. 6. ed, pp.6-7 e 11.

40 SCHOUERI, Luís Eduardo. Princípios no direito tributário internacional: territorialidade, fonte e universalidade. In: FERRAZ, Roberto Catalano Botelho (coord.), Princípios e limites da tributação. São Paulo: Quartier Latin, 2005.), p. 328.
} 
inclusão, no antecedente de normas domésticas, de situações ocorridas no estrangeiro (jurisdiction to prescribe ou territorialidade material). ${ }^{41}$

Sob o prisma da tributação internacional, resta saber se, de fato, há limites à previsão no antecedente da norma tributária, ou se os Estados são absolutamente livres para alcançar quaisquer situações em qualquer parte do globo. Neste último caso, estar-seia a confirmar autoridade a um Estado, por exemplo, tributar estrangeiros sem qualquer vínculo com seu território.

Não parece razoável tal conclusão. A uma, pela impensável insegurança jurídica que atingiria o fluxo internacional dos fatores de produção; a duas, por ser ineficaz, carecendo de poder de concretização; a três, porque a liberdade franqueada aos Estados, pelo direito das gentes, embora ampla, não pode ser absoluta.

Ora, a soberania de um Estado é exercida, com exclusividade, sobre seu povo e seu território, donde se conclui que estas são as balizas por onde deve ser exercida a jurisdição. Tem-se, portanto, um elemento de conexão pessoal - povo- e outro real -território.

$\mathrm{Na}$ conexão pessoal ou subjetiva, o Estado costuma escolher residência ou domicílio do contribuinte. Poderá ocorrer de o Estado definir também a nacionalidade como elemento conectivo. De toda a sorte, em ambos os casos o Estado encontra-se apto ao exercício de sua soberania sobre o conjunto de nacionais natos e naturalizados, bem como sobre estrangeiros e apátridas estabelecidos em seus território. ${ }^{42}$ A conexão por nacionalidade prescinde da ligação territorial, mas não da pessoal, razão pela qual ainda que se encontre no exterior, o nacional não escapará da tributação de seu Estado.

Exemplo clássico de escolha de conexão pessoal pela nacionalidade se dá com os E.U.A., pois tributam seus nacionais e empresas incorporadas sob suas leis, independente do local onde aufiram rendas. A justificativa da política americana remonta ao caso Cook v. Tait (1924), quando a Suprema Corte dos EUA sustentou haver uma série de benefícios garantidos aos nacionais, como a constante proteção do governo e a possibilidade de retorno ao território norte-americano no momento em que desejarem, cuja disponibilidade deve ser custeada pela tributação. ${ }^{43}$

\footnotetext{
${ }^{41}$ L. E. Schoueri discorre sobre a visão de R.Silvestre J. Martha (The jurisdiction to tax in international Law: theory and practice of legislative fiscal jurisdiction (series on international taxation, $\mathrm{n}^{\circ} 9$ ), Denver, Kluwer, 1989, p.7.), para quem a discussão quanto à aplicação da territorialidade material teria sido inócua em Lotus. Isso pelo fato de a embarcação Boz-Kourt (bandeira turca) ser uma extensão do território turco, razão pela qual não teria havido alcance de fatos no estrangeiro. V. L.E. Schoueri, Princípios no direito tributário internacional: territorialidade, fonte e universalidade, pp.329-330.

${ }^{42}$ Cf. V. de O. Mazzuoli, Curso de direito internacional público, p. 179.

${ }^{43}$ Cf. R. Doernberg, International Taxation in a Nutshell, p.7. Os US Income Tax Regulations definem os nacionais dos EUA no §1.1-1(b): Citizens or residents of the United States. In general, all citizens of the
} 
Fato é, portanto, que a conexão com o Estado não se estabelece, unicamente, pela base territorial. A nacionalidade o comprova. Através de uma conexão pessoal, o Estado poderá tributar situações sem qualquer contato com seu território. Por essa razão, Schoueri sustenta que ao se cogitar da existência de um princípio da territorialidade, "não se defende a existência de uma limitação a fatos ocorridos num território, mas sim a exigência de que a situação a ser atingida pela tributação possua alguma conexão com o Estado tributante. É a "territorialidade material limitada"”, ${ }^{4}$

O elemento de conexão real ou objetivo exige vínculo entre situações materiais, de cunho econômico, a determinado território. Assim, importa observar se o local de situação dos bens, do exercício de uma atividade, de fonte de produção ou de pagamento, ou de um estabelecimento permanente está nos limites territoriais de determinado Estado.

A territorialidade em seu sentido clássico, como princípio limitador da tributação sem qualquer vínculo com o Estado tributante perdeu espaço, pois não é suficiente para delimitar competência tributária internacional. Em sistemas pouco evoluídos, em que as hipóteses de incidência costumam ocorrer em apenas um território ou que a localização dos fatos geradores é nítida (tributos sobre consumo, sobre imóveis etc.) poderá ter valia, porém, ante formas tributárias mais aperfeiçoadas que ensejam grandes dificuldades pela desmaterialização dos critérios da hipótese de incidência será praticamente inócua, abrindo espaço ao princípio da universalidade. ${ }^{45}$

Neste giro, a personalização dos impostos, em atenção à capacidade contributiva, tende para a conexão pessoal - residência, sede ou domicílio - priorizando o vínculo com o próprio Estado em detrimento daquele com o território. Doutrina contemporânea reconhece a pouca valia da territorialidade na construção dogmática do direito tributário internacional, preferindo princípios de conteúdo preceptivo mais denso como fonte e residência. $^{46}$

O princípio da universalidade (worldwide income taxation) reflete a escolha, por parte do Estado, de uma conexão pessoal, eis que seu residente ou nacional deverá oferecer

United states, wherever resident (...) are liable to the income taxes imposed by the Code whether the income is received from sources within or without the United States (...); e no \$1.1-1(c) Who is a citizen. Every person born or naturalized in the United States and subject to its jurisdiction is a citizen (...).

${ }^{44}$ Cf. L.E. Schoueri, Princípios no direito tributário internacional: territorialidade, fonte e universalidade,, p.336.

${ }^{45}$ Cf. A. Xavier, Direito tributário internacional do Brasil. 6. ed, pp. 28-29; L.E. Schoueri, Princípios no direito tributário internacional: territorialidade, fonte e universalidade, p. 337.

${ }^{46}$ Cf. A. Xavier, Direito tributário internacional do Brasil. 6. ed, pp. 28-29; L.E. Schoueri, Princípios no direito tributário internacional: territorialidade, fonte e universalidade, p. 337. 
à tributação a totalidade das rendas que auferir, seja fruto de situações internas ou internacionais.

A universalidade atende, prioritariamente, aos interesses dos países exportadores de capital, tendo como justificativas para sua implantação, em síntese:

(i) respeitar a neutralidade de exportação de capital, tributando o investidor que aplicar recursos internamente tanto quanto o investidor internacional;

(ii) respeitar a igualdade, atendendo à progressividade e à capacidade contributiva dos que recebem renda interna ou no exterior;

(iii) atender a reclames de política fiscal, buscando ingressos tributários;

(iv) combater a elisão e a evasão fiscais, decorrência da concorrência tributária nociva.

O quadro abaixo resume o que foi exposto neste tópico:

\begin{tabular}{|l|l|l|}
\hline Situação & Princípio & Conexão \\
\hline $\begin{array}{l}\text { Residente - renda no } \\
\text { território }\end{array}$ & Territorialidade/universalidade & Real/pessoal \\
\hline $\begin{array}{l}\text { Residente - renda no } \\
\text { exterior }\end{array}$ & Universalidade & Pessoal \\
\hline $\begin{array}{l}\text { Não-Residente - renda no } \\
\text { território }\end{array}$ & Territorialidade & Real \\
\hline $\begin{array}{l}\text { Não-Residente - renda no } \\
\text { exterior }\end{array}$ & Não-incidência & Não há \\
\hline
\end{tabular}

No Brasil, a tributação em bases universais foi inteiramente concretizada por meio da Lei 9.249/95, que assim dispõe em seu art. 25:

Art. 25. Os lucros, rendimentos e ganhos de capital auferidos no exterior serão computados na determinação do lucro real das pessoas jurídicas correspondente ao balanço levantado em 31 de dezembro de cada ano. 
Até que a referida Lei passasse a produzir efeitos (01 de janeiro de 1996), somente pessoas físicas eram tributadas em bases universais - worldwide income taxation -, com base no Decreto-Lei 1.168/39.

A universalidade atende aos imperativos da capacidade contributiva, submetendo o total da rendas dos residentes à tributação independente do local onde foram produzidas. Assim, favorece à neutralidade de exportação de capital, pois torna indiferente ao contribuinte brasileiro investir internamente ou no exterior.

\section{I.1.3 Tributação pelo Estado da fonte e pelo Estado da residência}

Derivação do princípio da territorialidade, os princípios da fonte e residência ganham espaço na construção dogmática do direito tributário internacional. Como explicitado no tópico precedente, a territorialidade não mais enseja a conexão com um dado território, mas com o próprio Estado soberano. ${ }^{47}$

A territorialidade pode ser observada em sentido real e pessoal. A territorialidade pessoal impõe que a tributação se limite a pessoas residentes ou domiciliadas no território do Estado - princípio da residência -, ao passo que a territorialidade real exige vínculo entre a situação alcançada pela tributação e o território -princípio da fonte. ${ }^{48}$

O princípio da fonte decorre da conexão real (objetiva), permitindo a tributação sobre situação ocorrida nos limites de dado território. Não se confunde, porém, com o princípio da territorialidade, que lhe supera em alcance, pois pode abranger situações cuja conexão seja pessoal. Seria, na realidade, o que se chama de territorialidade real. ${ }^{49}$

Já o princípio da residência exige um elemento de conexão pessoal (subjetiva), tanto para gravar situações ocorridas no território do Estado tributante, como para alcançar aquelas internacionais. No primeiro caso, a sistemática de tributação vigente poderá ser em bases territoriais ou universais; mas no último, para alcançar situações no exterior, o Estado deverá ter optado, forçosamente, pela universalidade. Como se vê, o princípio da residência não está indissociavelmente ligado à universalidade.

\footnotetext{
${ }^{47}$ SCHOUERI, Luís Eduardo. Direito tributário. São Paulo: Saraiva, 2011, p. 679.

${ }^{48}$ Cf. L.E. Schoueri, Princípios no direito tributário internacional: territorialidade, fonte e universalidade, pp.326-327.

${ }^{49}$ Cf. L.E. Schoueri, Princípios no direito tributário internacional: territorialidade, fonte e universalidade, pp. 342-343.
} 
Ainda neste mesmo raciocínio, pode-se concluir que universalidade não afasta territorialidade, já que a tributação das rendas mundiais antes alcança as rendas territoriais. Logo, na situação do residente auferindo renda em seu território, há uma cumulação de conexões pessoal e real que reflete, por assim dizer, territorialidade com universalidade. ${ }^{50}$

O binômio fonte-residência está no cerne da discussão corrente sobre tributação internacional, sem, todavia, encontrar-se imune à sofisticação dos arranjos empresariais globais e aos desafios do ciberespaço.

Com efeito, esses são temas que precisam ser enfrentados, embora ainda estejam longe de apresentar solução a casos em que a residência pode se encontrar em mais de um Estado, bem como migrar ou esconder-se sob a desmaterialização dos critérios que integram a norma de incidência tributária.

\section{I.1.4 Tributação e comércio eletrônico}

No compasso das alterações em curso no cenário mundial, a questão do comércio eletrônico (e-commerce) - inobstante discutida há mais de uma década- ${ }^{51}$ posta-se na condição de desafio ainda insolúvel ao direito. ${ }^{52}$

A despeito de os efeitos das transações do comércio eletrônico poderem se circunscrever a uma só jurisdição, quando todos os envolvidos nas transações se localizarem em um mesmo Estado, o objeto do presente estudo se baliza pelo enfoque da

\footnotetext{
${ }^{50}$ Cf. H. T. Tôrres, Pluritributação internacional sobre as rendas de empresas, p.89.

${ }^{51}$ A Conferência de Turku (Finlândia), em novembro de 1997, marcou o início dos trabalhos da OCDE para desenvolver condições de estruturação da tributação do comércio eletrônico. Em outubro de 1998, a Conferência de Ottawa (Canadá) deu prosseguimento aos trabalhos, divulgando um conjunto dessas condições elaborado por membros da OCDE e vários terceiros países (África do Sul, Argentina, Brasil, Chile, China, Hong Kong (China), Israel, Malásia, Rússia, Singapura, Taipé Chinesa), além de organizações internacionais intergovernamentais como o Centro Interamericano de Administrações Tributárias (CIAT), Associação das Administrações tributárias da Commonwealth (CATA), União Européia, Organização Mundial de Aduana (OMA) e o empresariado. Como resultado desta última, a OCDE elencou alguns princípios a serem considerados pelos Estados com vistas a preservarem suas bases de arrecadação garantindo, ao mesmo tempo, o florescimento do comércio eletrônico. São eles: neutralidade, eficiência, certeza e simplicidade, eficácia e justice; e flexibilidade. (http://www.oecd.org/dataoecd/4/56/14990201.pdf e http://www.oecd.org/dataoecd/46/3/1923256.pdf, acesso 12 out 2011)

${ }^{5} \mathrm{Na}$ expressão de Antônio Carlos Diniz, o Direito ocidental moderno teria sido construído sobre certezas, dogmas, restando-lhe tradição conservadora. "Constatado o acelerado anacronismo de muitas formas e modelos jurídicos de caráter unívoco, linear, causal e determinista forjado nos séculos passados, torna-se indispensável a abertura para uma outra compreensão dos fenômenos complexos. A conjugação de fatores tais como o desenvolvimento recente de tecnologias da informação, globalização da economia, aceleração das mutações culturais, multiplicação dos fenômenos transculturais, surgimento de novos riscos ambientais em escala planetária sofisticação crescente dos métodos de controle social, desenvolvimento de modos alternativos de regulação, tudo se opõe aos cânones filosóficos de direitos criados para atender às demandas dos séculos de outrora.” Cf. A.C. Diniz, Pós-modernismo, (nota 81.I), p.649.
} 
tributação internacional da renda. É neste campo que se pode ensejar o concurso de pretensões por parte de mais de um Estado soberano, reavivando a célebre discussão fonte/residência quanto à competência tributária para alcançar a renda dos negócios virtuais.

Diferentemente do comércio tradicional, o ciberespaço dispensa presença física e desconhece fronteiras, características fundamentais dos sistemas de tributação em geral. ${ }^{53}$ Ante essa nova realidade, as administrações fazendárias vêem-se obrigadas a alterar sua forma de atuação, buscando maior eficácia no exercício de suas funções.

Em operações internacionais, resta, portanto, indagar como se poderá tributar a renda produzida em determinada operação e, além disso, qual a jurisdição legítima para a imposição tributária. ${ }^{54}$

O arquétipo tradicional da repartição de competências, na tributação internacional, assim se resume: ${ }^{55}$

(i) a renda é dividida entre o Estado do qual deriva (fonte) e no qual seu destinatário é residente (residência);

(ii) renda derivada de operações com presença física na fonte são tributadas na própria fonte, do mesmo modo que as empresas residentes (sobre o lucro);

(iii) renda de investimentos (portfólio) e intangíveis, se não isentas, geralmente são tributadas por retenção na fonte;

(iv) a residência costuma tributar toda a renda, concedendo, no entanto, isenção para a renda já tributada na fonte ou crédito pelo imposto recolhido na fonte.

Historicamente, desde os trabalhos iniciados pela Liga das Nações no primeiro quartel do século passado, ${ }^{56}$ há o predomínio da tributação pela residência, que, inclusive, se encontra consubstanciado nos Modelos de Acordo de bitributação da OCDE e da ONU,

${ }^{53}$ TILLINGHAST, David. Internet: the impact of the internet on the taxation of international transactions. In: Bulletin for international fiscal documentation, nov/dez, 1997, p. 524. O autor relembra a tradição commercial em exigir o envio físico de bens tangíveis ou mesmo presence física de prestadores de serviços e conclui: "The examples could be multiplied, but the theme is the same: traditional suppositions of the way in which commerce is carried out do not reflect what actually happens in the Internet era."

${ }^{54}$ SKAAR, Arvid Aage. Erosion of the concept of permanent establishment: electronic commerce. In: Intertax, v. 28, 2000, p. 188. V., ainda, SCHOUERI, Luís Eduardo. Imposto de renda e comércio eletrônico. In: COSTA, Alcides Jorge et SCHOUERI, Luís Eduardo (coord.), Direito Tributário Atual 16. São Paulo: Dialética, 2001. p. 146.

${ }^{55} \mathrm{Cf}$. D. Tillinghast, Internet: the impact of the internet on the taxation of international transactions, p. 525.

${ }^{56}$ Os primeiros estudos sobre bitributação empreendidos pela Liga das Nações encontram-se no memorando preparado por Sir Basil P. Bçackett, em 15 de janeiro de 1921, que discorria sobre tributação na fonte e na residência no Império Britânico. V. L.E. Schoueri, Tratados e convenções internacionais sobre tributação, in: COSTA, A. J.; SCHOUERI, L.E. e BONILHA, P.C.B. (coord.), Direito Tributário Atual 17. São Paulo: Dialética, 2002 ou 2003. p. 28. 
sem que para tanto haja suficiente suporte científico ou jurídico. Na verdade, a opção dessas organizações tem justificativa política, já que a tributação prioritária na residência vai ao encontro do interesse dos países tradicionalmente exportadores de capital, os quais representam a vasta composição da primeira e exercem maior peso nas deliberações da segunda.

A tributação pelo Estado-residência, no comércio eletrônico, suscita enormes dificuldades quanto à identificação do próprio local em que se estabelece determinada empresa. Aliás, mesmo no comércio tradicional, os critérios para fixação de residência variam de país a país, ensejando, muita vez, a atribuição de dupla residência que poderá levar à bitributação. ${ }^{57}$ Esse efeito é potencialmente multiplicado no comércio eletrônico, onde "a definição da jurisdição do fato econômico fica mais tênue nas operações on-line, tornando-se mais difícil a identificação da origem e do destino da transação." 58

Dentre as críticas a dois dos principais critérios de fixação de residência - local da incorporação e direção efetiva -, destacam-se:

(i) o estímulo a que empresas sejam constituídas em paraísos fiscais, onde poderão continuar a funcionar à distância, já que não haverá testes de atividade substancial;

(ii) a impossibilidade de definir com exatidão o centro de decisões administrativas da empresa, considerando que os recursos tecnológicos permitem reuniões em locais diversos $;{ }^{59} \mathrm{e}$

(iii) a incerteza sobre o destino dos fluxos de rendimentos, pois não se pode garantir que estejam, no ciberespaço, retornando ao país de origem dos investimentos. ${ }^{60}$

Portanto, a dificuldade da identificação da origem ou do destino da transação conduz, em contrapartida, à posição em favor da fonte de pagamento para tributação do comércio eletrônico.

\footnotetext{
${ }^{57}$ Heleno Tôrres explica que os Estados costumam utilizar mais de um critério de determinação da residência de uma pessoa jurídica, principalmente para determinarem a conexão necessária à tributação universal. Aponta como os mais importantes critérios: lugar da incorporação; lugar da sede social; lugar da direção efetiva; lugar do poder de controle; lugar da atividade principal e head office. Cf. H. T. Tôrres, Pluritributação internacional sobre as rendas de empresas. 2. ed. São Paulo: Revista dos Tribunais. 2001, pp. 148-155.

${ }^{58}$ RECEITA FEDERAL DO BRASIL. O Brasil e o comércio eletrônico. Brasília, 2001. Disponível em: http://www.receita.fazenda.gov.br/Publico/estudotributarios/estatisticas/13BrasilComercioEletronico.pdf. Acesso em 12 set 2011.

59 VASCONCELLOS, Roberto França de. Tributação do comércio eletrônico internacional. Tese de doutorado - Faculdade de Direito da USP, São Paulo, 2002, pp. 127-128.

${ }^{60}$ Cf. L.E.Schoueri, Imposto de renda e comércio eletrônico, p. 154.
} 
Uma primeira justificativa para isso repousa na localização da fonte pagadora dos rendimentos ${ }^{61}$ destinados ao exterior. Os não-residentes são alcançados, como no caso do Brasil, pelo imposto de renda retido na fonte, independente de presença física. Se já ocorre dessa forma no comércio tradicional, mais razão assiste a que ocorra no eletrônico. Para tanto, a empresa residente poderia assumir o papel de agente de retenção da tributação incidente sobre o pagamento de bens ou serviços à empresa não-residente. ${ }^{62}$

Uma segunda razão decorre da perda sofrida pela economia da fonte pela remessa de pagamentos ao vendedor não-residente. Naturalmente que tal pagamento desgasta a base de arrecadação da fonte e, assim como sói ocorrer no comércio tradicional, o fluxo dos capitais empregados privilegia, em larga escala, a residência, pois ela reflete os exportadores de capital e também os produtos e serviços no bojo do comércio eletrônico.

A terceira justificativa confronta a localização da fonte de produção dos rendimentos com a fonte de pagamento. Virtualmente, mais difícil assegurar a identificação da primeira que da última, razão que levou Luís Eduardo Schoueri a preconizar a adoção da fonte de pagamento tanto em nome da simplicidade como da segurança. ${ }^{63}$

O desfecho das questões impostas ao direito tributário internacional em matéria de comércio eletrônico exige a aproximação dos Estados para a tentativa de construção de um consenso. Ações individuais calcadas em interesses particulares ameaçariam o desenvolvimento dessa modalidade de avanço comercial.

Fonte e residência, buscando o equilíbrio das rendas produzidas pelo comércio eletrônico poderiam quiçá abrir as portas para uma negociação mais profícua em termos de repartição de competência também na esfera do comércio tradicional, alterando-se, inclusive, os Modelos de Convenção de bitributação em que ainda se configure o privilégio da residência.

\footnotetext{
61 Por rendimentos, deve-se entender determinadas classes específicas de renda, como royalties, juros, dividendos ou pagamento de serviços.

${ }^{62}$ Roberto França de Vasconcellos explica que ao imposto retido na fonte deveria corresponder um crédito na residência do vendedor. A sugestão é acompanhada de uma breve análise da relevância do consenso internacional para a preservação das bases da fonte e da residência. Cf. R.F. de Vasconcellos, Tributação do comércio eletrônico internacional, pp. 138-139.

${ }^{63}$ Cf. L.E.Schoueri, Imposto de renda e comércio eletrônico, pp. 156-157. O autor registra que mesmo a fonte de pagamento enquanto critério para determinar a tributação no comércio eletrônico também estaria sujeita a críticas, pois pode ser rugoso, em alguns casos, identificar a residência de uma fonte pagadora. Em todo o caso, resta mais seguro que os critérios da residência e da fonte de produção dos rendimentos quanto às possibilidades de fugir da tributação, uma vez que "mais difícil conceber que uma multiplicidade de consumidores crie estruturas sofisticadíssimas para o pagamento de suas compras eletrônicas."
} 
Os residentes que marcam presença física no Estado-fonte, em geral, são tributados sobre seus lucros (não rendimentos) apurados naquela jurisdição. A presença física se dá por meio dos estabelecimentos permanentes que serão melhor explicados a seguir.

\section{I.1.5 Estabelecimentos Permanentes}

Inobstante tenha surgido em 1885, com o fito de prevenir a bitributação entre municípios na Prússia, o conceito de estabelecimento permanente (EP) ainda sofre revisões por organismos internacionais e apresenta dissensões entre as legislações nacionais. ${ }^{64} \mathrm{O}$ ar centenário do instituto não lhe preservou dos efeitos da revolução tecnológica e da globalização no mundo contemporâneo.

$\mathrm{O}$ conceito de EP evoluiu pelo século $\mathrm{XX}$ registrando o confronto entre as teorias da realização e da pertença econômica (economic allegiance). Agostinho Tavolaro as distingue pelo caráter imediatamente produtivo, já que, segundo a primeira, a configuração de um EP exigiria que as instalações localizadas em dada jurisdição produzissem lucro; ao passo que, para a segunda, bastaria a mera inserção das instalações na economia de um Estado, ainda que sem realização direta de lucro. ${ }^{65}$

A teoria da pertença econômica prevaleceu na definição de estabelecimento permanente constante dos Modelos da OCDE e da ONU. ${ }^{66} \mathrm{Com}$ efeito, ambos os modelos de convenção tratam do instituto em comento no artigo 5, cujo parágrafo 1 define estabelecimento permanente como instalação fixa de negócios através da qual as atividades da empresa sejam realizadas parcial ou integralmente. ${ }^{67}$

64 LEVINE, Howard J., WEINTRAUB, David A. When Does E-Commerce Result in a Permanent Establishment? The OECD's Initial Response. In: 29 Tax Management International J. 220, 2000.

65 Cf. TAVOLARO, Agostinho Toffoli. O estabelecimento permanente: instituto próprio do direito tributário internacional. Disponível em: http://www.tavolaroadvogados.com/doutrina/cs495.doc. Acesso em $07 \mathrm{dez}$ 2011, p.7. No mesmo sentido, v. A. Xavier, Direito tributário internacional do Brasil, pp. 676-677. Para maiores detalhes sobre conceito de EP, v. Heleno Tôrres, Pluritributação internacional sobre as rendas de empresas, pp.214-252.

${ }^{66}$ Os comentários da OCDE, reproduzidos pela ONU, sustentam que o caráter produtivo como característica de um EP talvez fizesse sentido no passado, mas não mais no presente. Em uma ampla organização, cada parte concorre para a produtividade do todo, não sendo possível inferir, diretamente, que uma vez que determinado estabelecimento apresente caráter produtivo num contexto organizacional mais amplo, ele será, por conseguinte, um EP, ao qual serão apropriadamente atribuídos lucros para fins de tributação em dada jurisdição. Cf. ONU, Comentários ao Art. 5 (1), item 3. Disponível em: ONU, United Nations Model double taxation convention between developed and developing countries, 2001. Disponível em: www.un.org/esa/ffd/documents/DoubleTaxation.pdf. Acesso em 15 out 2011, pp. 68-69.

${ }^{67}$ OCDE; ONU, Modelo de Acordo de Bitributação, Art. 5(1). For the purposes of this Convention, the term "permanent establishment" means a fixed place of business through which the business of an enterprise is wholly or partly carried on. (2). The term "permanent establishment" includes especially: a) a place of 
Assim, um conceito tradicional de EP exigiria, concomitantemente: (i) uma base fixa, física, ao dispor da empresa; (ii) onde as atividades da empresa sejam desempenhadas; (iii) com permanência algo demorada. ${ }^{68}$

Contudo, embora fixas, físicas e permanentes, algumas instalações foram excepcionadas do conceito de EP no âmbito convencional, pelo parágrafo 4 do artigo $5 .{ }^{69}$ O requisito que lhes falta diz com a atividade da empresa, que não deverá, para fins de qualificação como EP, ser meramente preparatória ou auxiliar. A atividade-fim da empresa é o lucro, razão pela qual, em regras gerais, tudo o que estiver ligado ao seu processo produtivo de forma direta e for realizado por uma base fixa em outra jurisdição deverá configurar um EP. Esta não é outra justificativa que não a da teoria da realização, consagrada por Carrol em 1933, que exclui do conceito as instalações usadas para fins de depósito, mostruário, despacho, publicidade e outras. ${ }^{70}$

Ocorre que o conceito evoluiu com o passar do tempo. Neste sentido, Paulo Caliendo ressalta ter havido uma ampliação semântica, partindo do chamado EP material exige sede fixa ao dispor da empresa - para alcançar, igualmente, a atuação de empresas sem sede fixa de negócios, como no caso dos agentes e dos projetos de construção. $\mathrm{O}$ agente pode dar ensejo ao EP pessoal, prescindindo de base fixa; já o projeto de construção prescinde da comprovação de permanência da atividade. ${ }^{71}$

Os EP pessoais atuam, no estrangeiro, por agentes intermediadores de negócios mandatários, agentes, comissários. ${ }^{72}$ No âmbito convencional, atribui-se o status de EP

management; $b$ ) a branch; $c$ ) an office; $d$ ) a factory; $e$ ) a workshop, and $f$ ) a mine, an oil or gas well, a quarry or any other place of extraction of natural resources. (grifo nosso)

${ }^{68}$ Cf. A. Xavier, Direito tributário internacional do Brasil, pp. 676-677.

${ }^{69}$ Este dispositivo é praticamente idêntico em ambos os Modelos, divergindo apenas na alínea "b", em que o Modelo ONU não prevê a entrega (delivery). OCDE, Modelo de Acordo de Bitributação, Art. 5(4). Notwithstanding the preceding provisions of this Article, the term "permanent establishment" shall be deemed not to include: $a$ ) the use of facilities solely for the purpose of storage, display or delivery of goods or merchandise belonging to the enterprise; $b$ ) the maintenance of a stock of goods or merchandise belonging to the enterprise solely for the purpose of storage, display or delivery; $c$ ) the maintenance of a stock of goods or merchandise belonging to the enterprise solely for the purpose of processing by another enterprise; $d$ ) the maintenance of a fixed place of business solely for the purpose of purchasing goods or merchandise or of collecting information, for the enterprise; $e$ ) the maintenance of a fixed place of business solely for the purpose of carrying on, for the enterprise, any other activity of a preparatory or auxiliary character; $f$ ) the maintenance of a fixed place of business solely for any combination of activities mentioned in subparagraphs a) to $e$ ), provided that the overall activity of the fixed place of business resulting from this combination is of a preparatory or auxiliary character. (grifo nosso)

${ }^{70}$ Cf. A. Xavier, Direito tributário internacional do Brasil, pp. 676-677.

${ }^{71}$ CALIENDO, Paulo, Estabelecimentos permanentes em direito tributário internacional, São Paulo: Revista dos Tribunais, 2005, p. 227.

72 OCDE, Modelo de Acordo de Bitributação, Art. 5 (5). Notwithstanding the provisions of paragraphs 1 and 2 , where a person - other than an agent of an independent status to whom paragraph 6 applies - is acting on behalf of an enterprise and has, and habitually exercises, in a Contracting State an authority to conclude contracts in the name of the enterprise, that enterprise shall be deemed to have a permanent establishment in 
pessoal a quem puder firmar contratos em nome e por conta da empresa não-residente; possuir estoque de mercadorias para concluir ordens de comercialização; ou representar, exclusivamente, uma única empresa. Logo, agentes independentes não estarão inclusos no conceito (brokers). ${ }^{73}$

As convenções modelo da ONU e da OCDE têm exercido grande influência na celebração de acordos bilaterais que visam a evitar a bitributação e a preservar o fluxo internacional de investimentos. A despeito de os textos serem bastante próximos, divergências surgem na medida que o corpo de membros de cada organização internacional tem interesses distintos. Se a OCDE representa, quase que integralmente, os países de tradição exportadora de capital, priorizando a residência; a ONU tem maior compromisso com a fonte.

Destarte, o EP recebe tratamento mais abrangente no Modelo ONU, convergindo com o interesse da fonte. Assim é que projetos de montagem e atividades de supervisão, não previstos nos acordos aos moldes da OCDE, somam-se aos canteiros de obras e projetos de instalação e construção, para configurarem EP. Neste ponto, a ONU estende o alcance do conceito de EP não só pelas hipóteses contempladas, mas também pela redução do prazo da atividade estrangeira, que bastará superar seis meses, e não doze, como no Modelo OCDE.

A ONU também se distancia da OCDE ao considerar estabelecimento permanente o fornecimento de serviços, incluindo consultorias, desde que para um mesmo ou relacionado projeto, por um período ou somatório de períodos superior a seis meses dentro de qualquer período de doze meses. ${ }^{74}$

A forma de atuação de uma empresa no contexto internacional, com relação à jurisdição da fonte, pode ocorrer por atos isolados, esporádicos, praticados sem presença

that State in respect of any activities which that person undertakes for the enterprise, unless the activities of such person are limited to those mentioned in paragraph 4 which, if exercised through a fixed place of business, would not make this fixed place of business a permanent establishment under the provisions of that paragraph. (grifo nosso).

${ }^{73}$ Cf. H. T. Tôrres, Pluritributação internacional sobre as rendas de empresas, pp. 230-231. Segundo o autor, mandatários agem em nome e por conta da empresa não-residente; comissários são os que atuam apenas por conta da empresa não-residente; e agentes são os que apenas angariam negócios para o representado.

${ }^{74} \mathrm{O}$ acordo Brasil-China segue o Modelo ONU em seu art. 5(3): A expressão "estabelecimento permanente" compreende ainda:

a) um canteiro de obras, uma edificação, montagem ou implantação de projeto ou atividades de supervisão dos mesmos, desde que tais atividades tenham continuidade por período superior a seis meses;

b) a prestação de serviços, inclusive de consultoria, por empresas de um Estado Contratante, por intermédio de funcionários ou de pessoal contratado no outro Estado Contratante, desde que tais atividades tenham seqüência, em um mesmo projeto, ou outro projeto a ele relacionado, por um período ou períodos perfazendo mais de seis meses dentro de qualquer período de 12 meses. V. A.T.Tavolaro, $O$ estabelecimento permanente: instituto próprio do direito tributário internacional, p. 9. 
fixa; por uma atuação direta, caracterizada por meio da instalação de filiais, sucursais ou agências; ou, ainda, por atuação indireta, exercida pela participação societária em empresas independentes - subsidiárias, coligadas e controladas.

Fato é que a tributação de não-residentes só poderá ocorrer em face da constatação de algum elemento de conexão com a jurisdição da fonte. Como não há conexão pessoal entre não-residentes e fonte, a esta última resta tributar os rendimentos, por aqueles obtidos em seu território, pela conexão real/objetiva da fonte de pagamento ou de produção dos rendimentos.

É justamente a mudança no critério conectivo a resultante da presença de um EP em dado Estado, pois pela equiparação a residentes, os não-residentes estarão conectados pessoalmente, o que ensejará a tributação sobre as rendas universais (worldwide income taxation), caso seja esta a sistemática adotada pela fonte, como é o caso do Brasil. ${ }^{75} \mathrm{Na}$ verdade, o EP expressaria atuação da empresa estrangeira não por atos isolados, mas por funcionamento (doing business) na jurisdição da fonte.

É vero que a qualificação como EP pode resultar de normas domésticas de dado Estado, em face da atuação algo demorada de uma empresa não-residente em seu território. Por essa razão, não há uniformidade quanto ao tema no cenário internacional. No direito interno brasileiro, por exemplo, não há definição expressa de estabelecimento permanente, de modo que o conceito de EP encontra-se restrito pelos acordos de bitributação celebrados pelo Brasil.

Assim, o domicilio tributário da empresa não-residente que exerce atividade no Brasil deverá seguir a regra do art. 4 (residência) dos acordos de bitributação firmados pelo País, ou, ante situação em que não haja acordo celebrado com o Estado de residência da empresa, o CTN. Nesta última hipótese, Heleno Tôrres entende que se deva recorrer ao art. 126, III, do referido diploma legal, onde se lê que a capacidade tributária passiva independe de estar a pessoa jurídica regularmente constituída, bastando que configure uma unidade econômica ou profissional. ${ }^{76}$ Dissente desta opinião Agostinho Tavolaro, para quem a atribuição de domicílio ao estabelecimento de empresa estrangeira encontra sede no art. 127, II do CTN, que considera domicílio tributário, ante a falta de eleição por parte

\footnotetext{
${ }^{75}$ Paulo Caliendo sustenta que "na alteração de atuação isolada para uma atuação orgânica ocorrerá como conseqüência a alteração na caracterização do tratamento a ser dispensado às rendas produzidas por esta. As rendas produzidas deixarão de ser consideradas em seu sentido unitário, singular, esporádico e não habitual e passarão a ser consideradas em seu sentido orgânico, ou melhor dizendo, sintético. Passarão, dessa maneira a ser tributadas considerando-se a totalidade de seus componentes positivos e negativos e em conformidade com as normas comerciais e escriturais pertinentes." Cf. CALIENDO, Paulo, Estabelecimentos permanentes em direito tributário internacional, São Paulo: Revista dos Tribunais, 2005, p. 224.

${ }^{76}$ Cf. H. T. Tôrres, Pluritributação internacional sobre as rendas de empresas, p. 250.
} 
do contribuinte, o lugar de seu estabelecimento em relação aos fatos ou atos que derem origem à obrigação tributária. ${ }^{77}$

Parece mais acertado, porém, recorrer a ambos os artigos do CTN, pois o art.126 cuida de unidade econômica ou profissional independente de seu regular cadastramento na base de dados do fisco, o que é relevante para, em uma análise casuística, decidir sobre a configuração e existência de um EP atuando em jurisdição nacional. Contudo, a definição do domicílio dessa unidade irregular perante a autoridade fazendária encontra amparo no art. 127, satisfazendo situações de atuação de EP pessoais e EP materiais em seus incisos I e II, respectivamente.

Paulo Caliendo defende que a ausência de um tratamento específico sobre EP por parte do legislador pátrio não significa ausência de previsão normativa sobre o fenômeno da organização estável. ${ }^{78}$ Assim, o art. 147 do Regulamento do Imposto de Renda - RIR considera pessoas jurídicas para efeito de caracterização como contribuintes do IR:

(i) as filiais, sucursais, agências ou representações no País das pessoas jurídicas com sede no exterior; e

(ii) os comitentes domiciliados no exterior, quanto aos resultados das operações realizadas por seus mandatários ou comissários no País.

Desta forma, o tratamento conferido pelo RIR não seria idêntico ao previsto pelos acordos celebrados pelo Brasil, nos mesmos moldes do modelo OCDE, já que dispara previsão taxativa (não exemplificativa) e restritiva, nada dispondo sobre algumas situações previstas no âmbito convencional, tais como projetos de construção. Na mesma esteira, a norma brasileira não enumera positiva ou negativamente os casos considerados organizações estáveis. ${ }^{79}$

Basicamente, o estabelecimento permanente vem derrogar o princípio geral, insculpido no Art. 7(1) da Convenção Modelo da OCDE, ${ }^{80}$ segundo o qual os lucros de uma empresa devem ser tributados somente em seu Estado de residência. ${ }^{81} \mathrm{Na}$ verdade, em presença de um EP material ou pessoal, a fonte se torna competente para tributar os lucros

\footnotetext{
${ }^{77}$ Cf. A.T.Tavolaro, O estabelecimento permanente:instituto próprio do direito tributário internacional, p.11.

${ }^{78}$ Cf. P. Caliendo, Estabelecimentos permanentes em direito tributário internacional, p.238.

${ }^{79}$ Cf. P. Caliendo, Estabelecimentos permanentes em direito tributário internacional, p.239.

${ }^{80}$ OCDE, Modelo de Acordo de Bitributação, Art. 7 (1). The profits of an enterprise of a Contracting State shall be taxable only in that State unless the enterprise carries on business in the other Contracting State through a permanent establishment situated therein. If the enterprise carries on business as aforesaid, the profits of the enterprise may be taxed in the other State but only so much of them as is attributable to that permanent establishment.

${ }^{81}$ Cf. A. Xavier, Direito tributário internacional do Brasil, p. 673.
} 
da empresa estrangeira, mas unicamente na medida em que tais lucros corresponderem a esse estabelecimento permanente. ${ }^{82}$

Os lucros atribuíveis a um EP exigem o cálculo resultante do confronto entre receitas, despesas e custos em determinado período de tempo, relacionados à atividade do EP no Estado-fonte. Muitas vezes, porém, no caso do Brasil, o fisco preferiu entendimento diverso da aplicação do artigo 7 dos acordos de bitributação celebrados pelo País. Assim, por vezes considera as remessas para o exterior como royalties (art. 12) ou outros rendimentos (art. 21), tributando seu valor bruto na fonte.

Nos acordos de bitributação brasileiros, em geral, a atuação demorada da empresa estrangeira deve superar seis meses - exceção é o acordo com Israel, cuja previsão mínima é de nove meses-, o que é compreensível ante a posição dos países tradicionalmente importadores de capital -fonte - em dilargar as bases de arrecadação comprimidas na construção da dogmática do direito tributário internacional pela residência. ${ }^{83}$

Não bastasse a possibilidade de tratamento diverso quanto à qualificação de EP pelas várias jurisdições, o conceito é desafiado pelo comércio eletrônico, onde é possível haver uma empresa fabricante localizada em um Estado "A"; um servidor funcionando como base de dados, realizando operações de marketing para esta empresa em um Estado "B" e um consumidor acessando as informações disponibilizadas pelo servidor, via internet, residente no Estado "C".

Os desafios ao conceito de EP no seio do comércio eletrônico são grandes. Afinal, pode-se até considerar um servidor como EP material - local permanente de atividade-fim da empresa - ou EP pessoal - servidor que realize contratos diretamente com os consumidores-, mas daí a submetê-lo à tributação vai grande distância. A facilidade de mudar o local do servidor desencoraja o pioneirismo de dada jurisdição, concluindo-se que o tema exige consenso internacional para uma regulação mais eficaz. ${ }^{84}$

\section{I.1.6 Bitributação internacional}

\footnotetext{
${ }^{82} \mathrm{O}$ texto dos acordos, ao exigir que a tributação na fonte alcance apenas os lucros correspondentes ao EP, afasta a chamada força de atração, segundo a qual, a existência de um EP atrairia a tributação de "todos os rendimentos auferidos pela pessoa jurídica no Estado onde estivesse localizado o estabelecimento, sem se considerar se tais rendimentos seriam ou não decorrentes da atividade desse estabelecimento permanente." Cf. A.T. Tavolaro, O estabelecimento permanente: instituto próprio do direito tributário internacional,p. 11. ${ }^{83}$ No acordo Brasil-Israel (Dec. 5.576/05) prevaleceu uma regra intermediária, já que um canteiro de obra ou construção ou instalação ou montagem constituirá um estabelecimento permanente apenas se existir por mais de 9 meses.

${ }^{84}$ Cf. A.A.SKAAR, Erosion of the concept of permanent establishment: electronic commerce, p. 194.
} 


\section{I.1.6.1 Causas e efeitos da bitributação internacional}

A bitributação ou dupla tributação ou dupla imposição internacional ${ }^{85}$ decorre da previsão de um mesmo fato pelas hipóteses de incidência de duas normas emitidas por soberanias distintas. Trata-se, como se vê, de fenômeno resultante de concurso de normas. $^{86}$

Alberto Xavier entende que um mesmo fato tributário é constituído por diversos aspectos, a saber: material, subjetivo, espacial e temporal. Necessário, pois, para o fenômeno da bitributação, que ocorra a plena justaposição das hipóteses de incidência das normas tributárias em concurso, traduzida pelo que se denominou regra das quatro identidades: (i) mesmo pressuposto material; (ii) mesmo sujeito; (iii) mesmo período; (iv) mesmo tributo, ainda que com denominações distintas sob as normas de cada Estado soberano. $^{87}$

Assim, a aquisição de renda por um mesmo sujeito passivo, em um mesmo período, poderia gerar a pretensão tributária por mais de uma jurisdição. A identidade do período só faria sentido para tributos apurados no decurso de determinado lapso temporal e não para tributos de fato gerador instantâneo. Já a identidade do tributo merece criteriosa análise, pois a norma internacional deverá divergir, em terminologia, da norma doméstica quanto ao tributo em questão. É o caso da Contribuição Social sobre o Lucro LíquidoCSL, que teria destinação específica, divergindo do imposto de renda, mas que em tudo se lhe assemelha, devendo ser considerada em situações de concurso de normas, como sói ocorrer no campo de aplicação dos acordos de bitributação brasileiros. ${ }^{88}$

A identidade de sujeitos é questão fundamental para distinguir a dupla tributação jurídica de outro fenômeno que se tornou conhecido por dupla tributação econômica. A

\footnotetext{
${ }^{85}$ Heleno Tôrres, em defesa de maior rigor terminológico prefere o termo pluritributação internacional , uma vez que a bitributação decorreria do concurso impositivo resultante de estritas relações bilaterais, enquanto que a múltipla ou Pluritributação expressaria o resultado de tantas quantas fossem as pretensões nacionais. V. H. T. Tôrres, Pluritributação internacional sobre as rendas de empresas, p.378. Neste estudo, contudo, será mantido o termo bitributação com valor semântico generalizante, a menos que se ressalve.

${ }^{86}$ Esclareça-se que o fenômeno da bitributação pode surgir no bojo de um mesmo Estado, quando, por exemplo, dois entes federativos pretendem exercer sua competência tributária sobre um mesmo fato. Tratase, pois de bitributação, mas não de bitributação internacional, razão pela qual tal fenômeno não será analisado neste trabalho. É o que Alberto Xavier denomina dupla tributação vertical. Cf. A. Xavier, Direito tributário internacional do Brasil, pp. 39-40.

87 Xavier referencia as obras pioneiras na construção do conceito de bitributação de Spitaler , Das Doppelbeteuerungsproblem e de Guggenheim, L'imposition des sucessions. Cf. A. Xavier, Direito tributário internacional do Brasil, p. 33.

${ }^{88}$ TAVOLARO, Agostinho Toffoli. Impostos abrangidos pelos tratados de dupla tributação. Disponível em: http://www.tavolaroadvogados.com/doutrina/cs805.doc. Acesso em 07 out 2011.
} 
esse respeito, o primeiro modelo de convenção da OCDE de 1963 já fazia menção a ambas as expressões contrastando-as. A primeira diria respeito a situações em que a renda de um mesmo contribuinte estivesse sujeita à tributação por duas diferentes jurisdições; enquanto a segunda, a casos em que os mesmos lucros de entidades economicamente relacionadas usualmente empresas coligadas- fossem tributados por duas diferentes jurisdições. ${ }^{89}$

Dentre as causas para a bitributação internacional, deverá haver a adoção da tributação universal (worldwide income taxtaion) por ao menos uma das jurisdições concorrentes. Se ambas as jurisdições aplicarem a tributação territorial (source income taxation), os riscos da bitributação reduzem-se significativamente, somente não sendo eliminados se as duas considerarem o mesmo fato tributário ocorrido em seus respectivos domínios.

Assim, o concurso impositivo de dois Estados soberanos dependerá do elemento de conexão de cada um desses Estados com o fato jurídico tributário. Sem uma conexão pessoal pela residência ou nacionalidade ou uma conexão material, objetiva, pela fonte de produção do rendimento, a obrigação tributária não ocorre.

Os seguintes exemplos permitem maior clareza quanto às causas e efeitos da bitributação internacional:

(i) considere dois Estados, A e B, que tributam a renda em bases universais a $40 \%$ e $30 \%$, respectivamente. O contribuinte $\mathrm{C}$, residente em A, ao auferir $\$ 100$ em rendimentos em $\mathrm{B}$, sofrerá bitributação, pois existe a conexão material com $\mathrm{B}$ pela fonte e conexão pessoal com A pela residência. Logo, C terá de pagar \$30 em B e \$40 em A, totalizando tributação de $\$ 70$. Com relação ao contribuinte $\mathrm{D}$, igualmente residente em $\mathrm{A}$, mas que aufere os mesmos $\$ 100$ de rendimentos em A, o Estado B não o alcança por falta de conexão restando-lhe pagar $\$ 40$ e nada mais. Neste caso, há nítida vantagem aos contribuintes que somente investirem na própria jurisdição, o que significa quebra da neutralidade de exportação de capital;

(ii) suponha agora que o Estado A tributa a renda universal enquanto o Estado B adota a tributação territorial, mantidas as mesmas alíquotas. Se o contribuinte $\mathrm{C}$, residente

${ }^{89}$ OCDE, Taxing profits in a global economy- domestic and international issues, OECD, Paris, 1991, ISBN 92-64-13596-0, p. 17. Heleno Tôrres critica a expressão dupla tributação econômica por entendê-la algo imprecisa e contraditória. Na verdade não se poderia qualificar de econômica a dupla tributação, pois que o fenômeno em tela não pressupõe a unidade de contribuintes e nem o concurso de normas sobre um mesmo fato tributável. Sugere, pois o termo dupla tributação por transferência, o qual pode ser dividido em diversas formas, dentre as quais destaca a dupla tributação internacional por transferência de preços - para os casos de trsnsfer pricnig entre coligadas e a dupla tributação internacional por distribuição societária, para os casos de transferência de lucros em que a empresa é tributada pela produção desses lucros e os sócios, em outro Estado, pela recepção. V. H.Tôrres, Pluritributação internacional sobre as rendas de empresas, p.410. 
em A, auferir \$100 em rendimentos provenientes de B, ocorrerá a bitributação. Isso por causa da imposição pela conexão material pela fonte em B $(\$ 30)$ e a conexão pessoal pela residência em $\mathrm{A}(\$ 40)$. Caso o contribuinte $\mathrm{D}$ aufira $\$ 100$ de rendimentos oriundos de seu Estado de residência $\mathrm{A}$, não haverá tributação em B por falta de conexão com aquela jurisdição. Uma vez mais pode-se perceber a quebra da neutralidade de exportação de capital, uma vez que a tributação será diferente caso o residente em A decida investir internamente ou no exterior; e

(iii) se, por outro lado, os Estados A e B adotarem a tributação territorial da renda, o contribuinte $\mathrm{C}$, ao auferir $\$ 100$ em rendimentos provenientes de $\mathrm{B}$, não se sujeitará à tributação em A (\$0), inocorrendo a bitributação, pois somente pagaria \$30 para B.

Pode-se afirmar com segurança que a bitributação é um dos maiores temas da pósmodernidade, pois a alta mobilidade do capital, típica da contemporaneidade, torna-o mais sensível ao tributo. Por conseguinte, a bitributação torna-se um dos maiores entraves ao investimento estrangeiro. Não por outra razão Tavolaro a definiu como o mais importante tema do direito tributário internacional, ${ }^{90}$ enquanto que Yariv Brauner reforça esta idéia ao colocá-la como preocupação central de uma rede de cerca de 3.000 acordos bilaterais cujo fim precípuo é afastá-la. ${ }^{91}$

Inobstante a distorção que causa sobre a neutralidade, sob o aspecto jurídico a bitributação não pode ser vista como ilicitude. Nada na ordem jurídica internacional veda a norma tributária de determinado Estado de prever situações que possam apresentar a característica da estraneidade. Em outro giro, a mesma situação encontrar-se sob a esfera de interesse de mais de jurisdição é um risco a ser reduzido por medidas unilaterais previstas na própria ordem interna ou por meio de arranjos bilaterais a serem negociados e firmados por essas jurisdições.

Schoueri noticia duas tentativas de qualificar a bitributação como antijurídica com base na violação dos princípios de direito geralmente reconhecidos, expressamente reconhecidos pelo art. 38 do Estatuto da CIJ como fonte de direito internacional. Contudo, prevalece na ordem internacional o entendimento de que não há um princípio geral que limite a pretensão tributária de um Estado, ainda que coincidente com a de outro Estado

\footnotetext{
${ }^{90}$ TAVOLARO, Agostinho Toffoli. Tratados para evitar a dupla tributação internacional. In: MARTINS, Ives Gandra da Silva (coord.), Curso de direito tributário. 12. ed. São Paulo: Saraiva, 2010. p. 571.

${ }^{91}$ BRAUNER, Yariv .Direito do comércio internacional e acordos tributários. In: COSTA, Alcides Jorge; SCHOUERI, Luís Eduardo e BONILHA, Paulo Celso Bergstrom (coord.), Direito Tributário Atual 23. São Paulo: Dialética, 2009. p. 14.
} 
soberano. ${ }^{92} \mathrm{O}$ interesse em reduzir os efeitos da bitributação tem justificativa econômica, mas não vedação jurídica.

Na primeira delas, Wilhelm Kann, em 1961, pretendia assegurar a vedação ao confisco na esfera internacional, já que, até a previsão expressa no art. $1^{\circ}$ do Protocolo adicional à Declaração dos Direitos do Homem na ONU, o direito de propriedade somente encontrava guarida na ordem interna. Para Kann, os Estados seriam obrigados a combater a bitributação na medida em que esta resultava da cumulação de suas pretensões e afrontava o direito de propriedade do contribuinte, gerando verdadeiro confisco na seara internacional. A segunda teoria, da lavra de Schaumburg, sustentou a ilicitude da bitributação baseada em violação do princípio da igualdade, posto que a cumulação de pretensões dos Estados violaria a capacidade contributiva - corolário da igualdade - do contribuinte $^{93}$

Muito embora não disponha contrariamente à ordem vigente, a bitributação deve ser afastada por representar entrave ao fluxo de comércio e de investimentos, uma das principais fontes de riqueza disputadas pelos Estados da pós-modernidade. Para tanto, os Estados podem adotar medidas unilateralmente ou negociarem acordos bilaterais com o fim de eliminar a bitributação.

\section{I.1.6.2 Medidas unilaterais de combate à bitributação: imputação e isenção}

Os métodos mais correntemente adotados pelos Estados são os da isenção e da imputação ou crédito. Ambos visam atender à neutralidade na tributação. Requisito básico de um sistema tributário que busque concretizar a justiça é revestir-se da discrição necessária para não influir na tomada de decisões empresariais. Apesar da lógica econômica apontar para essa direção, a realidade teima em contrariá-la, pois que os efeitos indutores da norma são, de forma matizada, levados em conta para qualquer decisão de alocação de recursos.

A neutralidade pode ser observada sob dois ângulos distintos. Ao estimular a produção dos lucros no exterior, o Estado " $A$ " resolve isentar as rendas obtidas por seus residentes no Estado "B". Destarte, os residentes de "A" poderiam competir no mercado de

${ }^{92}$ SCHOUERI, Luís Eduardo. Tratados e convenções internacionais sobre tributação. In: COSTA, Alcides Jorge; SCHOUERI, Luís Eduardo e BONILHA, Paulo Celso Bergstrom (coord.), Direito Tributário Atual 17. São Paulo: Dialética, 2003. p. 22.

${ }^{93}$ Cf. L.E.Schoueri, Tratados e convenções internacionais sobre tributação, p. 22. 
"B" em igualdade de condições com os residentes em "B", sujeitos todos à mesma imposição tributária. Este tratamento de igualdade tributária externa aos residentes atende à neutralidade de importação de capital- NIC. ${ }^{94}$

Poderá ocorrer de o Estado "A" tributar do mesmo modo as rendas obtidas por seus residentes, independente da origem, facultando-lhes optar pelo investimento doméstico ou internacional. Neste caso, o residente em "A" terá a desejada neutralidade de exportação de capital - NEC, pois receberá um crédito correspondente ao imposto pago no exterior (fonte). ${ }^{95}$

Comumente, a isenção é aplicada aos lucros (business income) obtidos no exterior (NIC), enquanto que a imputação ou crédito, aos rendimentos passivos, assim entendidos os derivados do capital, como juros, royalties, dividendos, aluguéis, ganhos de capital, desde que não afetos à atividade principal do contribuinte (NEC).

A isenção pode ser concedida de forma integral ou progressiva. ${ }^{96} \mathrm{Na}$ isenção integral, o Estado não alcança qualquer rendimento obtido no exterior por seus residentes. Ele desconsidera totalmente os rendimentos externos para efeito da base de cálculo do imposto de renda. Na isenção progressiva os rendimentos externos não são tributados pelo Estado de residência, no entanto são contabilizados para efeito de aplicação de uma alíquota progressiva. Assim, haveria um aumento da alíquota interna devido ao volume de renda obtido no exterior.

O crédito será reconhecido de forma integral (full credit) ou limitado à imposição do Estado de residência sobre os rendimentos externos.

O crédito integral será concedido ao residente que pagar tributos na fonte, independente dessa tributação superar a que seria imposta pelo Estado de residência sobre os rendimentos obtidos no exterior. Neste caso, o Estado de residência se veria na obrigação não só de renunciar as receitas tributárias, como de restituir ao investidor o excesso de crédito. Alternativamente, poderia conceder isenção ou efetivar a compensação com outros créditos que lhe fossem devidos pelo mesmo investidor. ${ }^{97}$

O mecanismo que não permite aos tributos pagos no exterior produzirem crédito de imposto em montante superior à tributação doméstica sobre os mesmos rendimentos estrangeiros é denominado crédito ordinário. Este mecanismo limita o valor do crédito

\footnotetext{
${ }^{94}$ Cf. J. Malherbe,, Controlled foreign corporations: revisitadas à luz dos tratados de bitributação e do direito comunitário europeu, pp. 103-104.

95 Cf. J. Malherbe, Controlled foreign corporations: revisitadas à luz dos tratados de bitributação e do direito comunitário europeu, p. 104.

${ }^{96}$ Cf. H. T. Tôrres, Pluritributação internacional sobre as rendas de empresas, pp. 433-436.

${ }^{97}$ Cf. H. T. Tôrres, Pluritributação internacional sobre as rendas de empresas, p. 443.
} 
concedido ao residente, sendo o mais amplamente utilizado pelos países, constando, inclusive, do Modelo da OCDE.

As escolhas dos métodos da isenção ou do crédito e de suas especificidades decorrem da política fiscal dos países, que deverá se ajustar à sua condição de exportador ou importador de capital.

O Brasil adotou o método do crédito ordinário em dispositivo da Lei 9.249/95, como medida de combate à bitributação jurídica. ${ }^{98}$ Além do crédito direto sobre os rendimentos, o legislador admitiu o crédito referente ao imposto pago no exterior também sobre os lucros, o chamado crédito indireto. ${ }^{99}$ Por conseguinte, unilateralmente, o Brasil baixou regras para combater a bitributação jurídica e a econômica. ${ }^{100}$

\section{I.1.6.3 Medidas bilaterais de combate à bitributação: acordos de bitributação}

Os acordos bilaterais para eliminar a bitributação prestam-se também a outras finalidades, como combate à evasão de receitas e garantia de políticas para atração do investimento estrangeiro. Exatamente por isso, essas convenções são cada vez mais importantes para os Estados, evidência igualmente decorrente do ambiente de concorrência internacional em que se encontram.

Dir-se-ia ainda mais, que os acordos de bitributação não devem ser vistos como artigos de luxo, mas como necessidade real para os Estados que busquem inserção internacional. Neste ponto, os países em desenvolvimento deveriam se esforçar para construir uma rede efetiva de acordos, especialmente com aqueloutros com os quais constroem seus fluxos de capital.

Na prática, além de conferirem maior segurança jurídica ao investidor estrangeiro, os acordos de bitributação limitam a jurisdição dos contratantes, reduzindo ou eliminado os riscos da bitributação. Ora atribuindo competência exclusiva a um dos contraentes, ora cumulando a competência de ambos, mas especificando limites para imposição, os acordos

\footnotetext{
98 BRASIL, Lei 9.249/95, Art. 26. A pessoa jurídica poderá compensar o imposto de renda incidente, no exterior, sobre os lucros, rendimentos e ganhos de capital computados no lucro real, até o limite do imposto de renda incidente, no Brasil, sobre os referidos lucros, rendimentos ou ganhos de capital.

${ }^{99}$ V. tópico IV.3.1.

${ }^{100}$ SCHOUERI, Luís Eduardo. Contribuição à história dos acordos de bitributação: a experiência brasileira. In: COSTA, Alcides Jorge; SCHOUERI, Luís Eduardo e BONILHA, Paulo Celso Bergstrom (coord.), Direito Tributário Atual 22. São Paulo: Dialética, 2008. p. 279.
} 
de bitributação representam a melhor alternativa para afastar a cumulação de pretensões, valendo-se, para tanto, dos métodos da isenção e da imputação ou crédito.

Embora representem manancial de situações do mais absoluto interesse jurídico, interessa observar os acordos de bitributação não apenas em sua faceta de combate à bitributação, mas como instrumento garantidor das normas tributárias indutoras voltadas à atração do IED e ao desenvolvimento econômico, conforme se verá no item III.2.

Por ora, cumpre dizer que os acordos de bitributação disponibilizam os mesmos métodos que podem ser utilizados unilateralmente pelos Estados, ou seja, (i) método da isenção integral (full exemption); (ii) método da isenção progressiva; (iii) método da imputação ordinária (crédito ordinário); e (iv) método da imputação integral, além do (v) método da dedução, que permite a dedução do imposto pago no exterior, a título de despesa, da base de cálculo do imposto a ser pago na residência. Não se trata de imputar o imposto pago na fonte contra o imposto a pagar na residência. ${ }^{101}$ Este método não persegue a neutralidade em quaisquer de suas formas, sendo menos eficaz que a isenção e o crédito quanto à eliminação da bitributação. ${ }^{102}$ A Convenção Modelo da OCDE trata do tema nos artigos 23-A e 23-B.

Nos arranjos bilaterais do Brasil, predomina o método do crédito, embora a isenção seja prevista em algumas convenções.

\section{I.1.7 Relação do Direito Tributário Internacional com o Direito Econômico}

O direito é produto da sociedade, mas que passa a condicioná-la e a modificá-la. ${ }^{103}$ A verdade expressa em ubi societas, ibi jus pode, igualmente, ser encontrada em $u b i$ commercium, ibi jus, já que às relações comerciais impõe-se o direito a regrá-las. ${ }^{104}$ No âmbito internacional não é de outro modo, já que a sociedade internacional contemporânea cada vez mais depende de cooperação entre seus sujeitos para a resolução de problemas afetos a temas comerciais e econômicos. ${ }^{105}$ Um exemplo feliz da justeza dessa assertiva está na participação mais efetiva dos PED nas deliberações econômicas internacionais, que

\footnotetext{
101 TAVOLARO, Agostinho Toffoli. Tratados para evitar a dupla tributação internacional. In: MARTINS, Ives Gandra da Silva (coord.), Curso de direito tributário. 12. ed. São Paulo: Saraiva, 2010. pp. 599.

${ }^{102}$ Cf. H. T. Tôrres, Pluritributação internacional sobre as rendas de empresas, p. 471

${ }^{103}$ Cf. Celso Mello, Curso de direito internacional público, 15 ed., Rio de Janeiro: Renovar, 2004, p.51.

${ }^{104}$ Cf. Celso Mello, Curso de direito internacional público, p. 78.

${ }^{105}$ Cf. Celso Mello, Curso de direito internacional público, pp.53-54.
} 
não resultou do acaso, mas de um avanço do direito motivado pela ação conjunta desses países em desenvolvimento.

Com o advento do sistema de Breton Woods, ao final da $2^{\text {a }}$ Guerra Mundial, houve a reformulação do sistema financeiro internacional e a criação do Fundo Monetário Internacional-FMI e do Banco Internacional de Reconstrução e Desenvolvimento - BIRD. Na seara comercial, pretendeu-se instituir a Organização Internacional do Comércio - OIT, mas sem êxito em virtude da falta de ratificações para tanto. ${ }^{106}$ Em seu lugar, atuou o provisório Acordo Geral sobre Tarifas e Comércio - GATT, cujo foco estava em reduzir as barreiras ao comércio pressupondo igualdade jurídica entre os Estados, concretizada em sua cláusula de nação mais favorecida - MFN. ${ }^{107}$ Segundo este dispositivo, o tratamento conferido a um dos contratantes, por determinado Estado, deveria ser, forçosamente, estendido aos demais.

Ocorre que o GATT estimulou a integração regional, da qual resultou o modelo da União Européia, levando os países em desenvolvimento a perceberem-se prejudicados, já que sentiam dificuldades em implantar políticas protecionistas e acordos preferenciais bilaterais. Em contrapartida, os PD tinham poder para influir nas regras do GATT e adotavam práticas protecionistas impeditivas aos PED. ${ }^{108}$

Contudo, foi no seio dos trabalhos da Assembléia Geral da ONU que surgiu uma manifestação expressa na Declaração do Programa de Ação para o Estabelecimento de uma Nova Ordem Econômica Internacional, em 1974 (Resolução 3.201 - S- VI), representando o interesse dos PED em participar de modo mais ativo no processo econômico internacional com base na equidade, interdependência e cooperação entre os Estados. ${ }^{109}$

Ressalta-se a atuação conjunta dos PED no seio da ONU, onde as deliberações podem ser tomadas - ressalvado o Conselho de Segurança - por maioria de votos, independente da participação financeira dos membros. Agindo em conjunto, os PED contribuíram, diretamente, no processo de alteração do cenário econômico internacional, conquistando mais peso e participação nas decisões desse matiz. Esses avanços

\footnotetext{
${ }^{106}$ MAGALHÃES, José Carlos de. Direito Econômico Internacional. Curitiba: Juruá, 2006, p. 66.

${ }^{107}$ Cf. J..C. de Magalhães, Direito Econômico Internacional., pp. 68-69.

${ }^{108}$ Cf. J..C. de Magalhães, Direito Econômico Internacional, pp. 71-72.

109 Esclareça-se que a tomada de decisão no arranjo de Breton Woods seguia o critério do voto ponderado, ou seja, quanto maior a subscrição, mais votos possuía o Estado. Naturalmente que os países desenvolvidos manobravam as decisões conforme seus interesses. Os países em desenvolvimento, por sua vez, adotaram postura crítica sobre este método, já que excluídos das decisões. Cf. J..C. de Magalhães, Direito Econômico Internacional, pp. 67-68 e p.77.
} 
representaram uma inovação impensada à época de Breton Woods e culminaram na criação da Organização Mundial do Comércio - OMC. ${ }^{110}$

À mudança de regime, com a participação de países em desenvolvimento, soma-se a globalização para alterar a tônica na economia internacional. A alternativa para o desenvolvimento dos países estaria na acirrada competição por IED. ${ }^{111}$

A fim de atrair o investimento externo ou garantir a exportação de seus produtos e serviços, os Estados passam a subvencionar determinados segmentos ou empresas. Tratase de prática regulada no âmbito da OMC, que poderá ser considerada legítima ou condenável, a depender de seu potencial nocivo com relação ao comércio internacional. É neste ponto que o direito tributário é compelido à observância do direito econômico internacional com mais vigor.

Em termos práticos, a legislação sobre o imposto de renda de um dado país pode ser elaborada com o objetivo de atrair o investidor estrangeiro. Será, portanto, uma norma dotada de estraneidade ao atingir situações de interesse de mais de uma jurisdição, e, conseguintemente, uma norma de direito tributário internacional que estará sujeita ao controle do Órgão de Solução de Controvérsias - OSC da OMC.

A lógica econômica sustenta que, assim como sanções mais pesadas deverão desestimular a prática da conduta sancionada, preços elevados de determinado produto ensejarão menor consumo desse produto. ${ }^{112}$ Esta simples dedução possibilita uma análise do comportamento do investidor estrangeiro com opções variadas de jurisdições à sua espera.

Tomando-se o Estado como um produto a ser comprado pelo investidor estrangeiro, este comprará menos do Estado quanto maior lhe for a tributação. Se os tributos forem baixos, ele tende a comprar mais desse Estado. A metáfora é conclusiva, pois o Estado pode, sim, representar um bom produto caso disponha de bens públicos de qualidade a ofertar. Se não os possuir, fatalmente suas chances de atração de investimento são pequenas, salvo se reduzir seus preços (tributos) visando a estimular o comprador (IED).

Portanto, ao reduzir ou eliminar a tributação sobre determinado segmento, forçoso é verificar se as normas tributárias indutoras conformam-se ao direito econômico internacional, sem que distorçam as regras comerciais em vigor.

\footnotetext{
${ }^{110}$ Cf. J.C. de Magalhães, Direito Econômico Internacional, p.79.

${ }^{111}$ Cf. J.C. de Magalhães, Direito Econômico Internacional, pp.102-103.

${ }^{112}$ COOTER, Robert; ULLEN, Thomas. Direito e economia, 5. ed. Porto Alegre: Bookman, 2010, p.25.
} 
Não é diferente o raciocínio se se submeter as regras de tributação à ordem jurídicoeconômica interna. No Brasil, a Constituição Federal prescreve princípios econômicos a serem devidamente observados pelo legislador que institui, majora ou alivia a tributação, dentre os quais o da propriedade privada, livre-concorrência, defesa do meio-ambiente, redução de desigualdades regionais e sociais, tratamento favorecido a empresas de pequeno porte, todos voltados à concretização da justiça social (art. 170) e ao desenvolvimento do País $\left(\operatorname{art.~} 3^{\circ}\right)$. 


\section{I.2 CONCLUSÕES DO CAPÍTULO}

I.2.1. O capítulo inicial procurou expor o contexto em que se encontra o Estado Fiscal perante as incertezas trazidas pela pós-modernidade. $\mathrm{O}$ avanço tecnológico aliado à busca por fatores de produção têm encurtado distâncias e reduzido barreiras comerciais. Em vista disso, tornaram-se comuns situações dotadas de estraneidade, que seriam alvo da pretensão tributária legítima por parte de mais de uma jurisdição. Sob o prisma internacional, a desmaterialização dos critérios de conexão, a evolução do conceito de estabelecimento permanente, a dicotomia entre fonte e residência, o direito de integração, as liberdades de circulação e a fuga de receitas são alguns dos desafios atuais ao Estado. Sob a ordem interna, há a necessidade de bem definir o papel do Estado, já que o desempenho de suas funções dependerá, em larga escala, da tributação. O resultado das decisões implantadas pelo Estado na órbita tributária interna e internacional definirá sobre sua inserção na ordem internacional.

I.2.2. O Estado que se pretenda competitivo deverá criar um ambiente propício aos fluxos de IED, o que, no contexto deste trabalho, será observado nos lindes da tributação internacional da renda. Com efeito, a tributação da renda deverá ser um fator cada vez mais relevante para as decisões alocativas do investidor, especialmente se se considerar os efeitos de transbordamento de outros sistemas tributários. Pelo ângulo do Estado, normas sobre tributação da renda devem ser confrontadas à sua política comercial, já que com a criação da OMC, o protecionismo foi reduzido e as subvenções a setores ou empresas foras reguladas. Inicialmente focada em impostos aduaneiros, o papel da OMC pode atingir norma sobre o imposto de renda cujo objetivo seja atrair o investidor estrangeiro, submetendo-a à apreciação de seu Órgão de Solução de Controvérsias - OSC, tal como ocorreu no paradigmático caso FSC.

I.2.3. A crescente concorrência entre os países pela preservação de suas bases tributárias conduziu o tributo à nova dimensão. Além de sua tradicional característica de receita derivada da sociedade aos cofres públicos, passa a atuar também como instrumento indutor do comportamento do agente econômico, o que por vezes se traduz pela renúncia de sua arrecadação. A criação de um ambiente propício aos fluxos de IED exige regulação do Estado sobre as normas de indução, mas sem que se perca de vista a fiscalidade. A questão está em atrair o investidor externo sem desestimular o investidor residente. 
I.2.4. O Estado pós-moderno luta para preservar suas receitas. Estímulo, confiança e transparência ao investidor são vitais. A tônica do novo formato é arrecadar com eficiência e igualdade, o que eleva o imposto de renda à condição de ótima ferramenta para promover redução de desigualdades de modo eficiente. No Brasil, o contraste entre o bom desempenho da economia e os altos índices de concentração da renda tornam essa análise ainda mais premente. A tarefa do legislador está a serviço da consecução de objetivos sociais relevantes, que devem ser mensurados para avaliar sua eficácia.

I.2.5. Para ser competitivo, o Brasil precisa se posicionar de forma harmônica perante os temas ora apresentados como desafios contemporâneos. Em princípio, o País é livre para fazer suas escolhas, mas tendo optado em 1995 pela tributação universal, precisa reduzir os riscos de bitributação, o que se pode dar por medidas unilaterais ou bilaterais. As medidas internas brasileiras podem ser tidas como salutares, pois admitem o crédito direto sobre rendimentos e ganhos de capital, mas também o crédito indireto, que é medida de alívio à bitributação econômica. Já as medidas bilaterais serão melhor analisadas no item III.2, mas podem ser entendidas como meios seguros de certeza e segurança ao investidor estrangeiro e ao nacional que atua no exterior. Se o Brasil sequer oferta convenção com a jurisdição do pretenso investidor, naturalmente que perde espaço. Poder-se-ia argumentar que o Brasil adota a reciprocidade, mas como principal fonte do DIP, o acordo confere maior estímulo à vinda do capital. Isso significa a estruturação de um ambiente propício aos fluxos de IED.

I.2.6. Alternativa auspiciosa está no engajamento no contexto BRIC de cooperação, pois a inserção internacional resultaria mais natural e ampla, trazendo recursos que impulsionariam o desenvolvimento com mais velocidade. A interação dos emergentes no BRIC pode significar mutação de alcance mundial, caso haja busca efetiva da construção de um modelo de relação sem precedentes, em que cada país - Brasil. Rússia, Índia e China, em defesa de seus interesses, aja de forma multilateral.

I.2.7. Garantir o desenvolvimento nacional é objetivo fundamental do Brasil ditado pelo constituinte (art. $3^{\circ}$, II). Partindo dessa premissa, a investigação caminhará nos capítulos seguintes para, ao final, afirmar ou infirmar eventual política de tributação da renda voltada para a competitividade. Releva saber se o legislador pátrio atua, de forma coerente 
quanto à tributação da renda, para a construção de um ambiente favorável aos fluxos de IED. E mais, se o legislador estaria ou não vinculado à formação desse ambiente.

I.2.8. A coerência da atuação do legislador com os ditames constitucionais será avaliada no capítulo IV por meio de testes sobre regras de tributação da renda. Com as análises e definições apresentadas até este ponto, pode-se, contudo, responder a última questão. Ora, a formação de um ambiente propício aos fluxos de IED é uma das alternativas à promoção do desenvolvimento. Destarte, certo é que vincula a atuação do legislador. Não seria aceitável que determinada norma interna atuasse em desfavor da jurisdição brasileira beneficiando a outro Estado. Os efeitos de uma conclusão desse matiz estarão presentes nas análises propostas a seguir, sendo que, mais especialmente, as balizas impostas ao legislador para atingir esses objetivos serão analisadas no capítulo seguinte. 


\title{
CAPÍTULO II- LIMITAÇÕES JURÍDICAS À CONCORRÊNCIA TRIBUTÁRIA INTERNACIONAL
}

\section{II.1 CONCORRÊNCIA TRIBUTÁRIA INTERNACIONAL}

\author{
II.1.1 Investimento Estrangeiro Direto - IED
}

Dentre um vasto conjunto de inovações e indefiniçõos que marca a pósmodernidade, destaca-se a globalização como um fenômeno em curso cujos efeitos ainda não são exatamente identificados. Assumindo que a globalização tenha partido de uma economia geopolítica, também denominada economia mundial dos Estados nacionais, sua trajetória aponta uma tendência de destinar-se à economia global. ${ }^{1}$

A economia geopolítica registra forte vinculação espacial de empreendimentos a uma base territorial de produção e vendas. Logo, as diversas células do empreendimento, como centro decisório-administrativo, laboratórios de $\mathrm{P} \& \mathrm{D}$, produção, fonte de insumos e energia, pontos de venda para escoamento da produção, tendem a se manter próximas. Adicionalmente, há custos e riscos atrelados a diversidades étnico-cultural e regulatórioinstitucional de outros Estados. O interesse em operações transnacionais, por parte das empresas e dos Estados que as hospedam, não é predominante. ${ }^{2}$

Por seu turno, a economia global caracteriza-se, em resumo, pela quebra de restrições nacionais aos fluxos migratórios; a redução de resistências étnico-culturais; e o decréscimo de poder dos Estados, dividido agora com novos atores globais, especialmente as MNEs e organizações internacionais supranacionais. ${ }^{3}$

A economia global franqueia melhor alocação de recursos às MNEs. Estas, bem aparelhadas quanto ao instrumental tecnológico, podem vencer distâncias com facilidades, dando ensejo a que suas células estejam dispostas em diversas partes do globo, consoante a

\footnotetext{
${ }^{1}$ PACHECO, Ricardo. Inserção na economia global: uma reapreciação. Pesquisas no 8. São Paulo: Fundação Konrad-Adenauer-Stiftung, 1997, pp. 6-7. O autor esclarece que os Estados possuem o poder de controlar os fluxos produtivos, mercantis, migratórios e monetários que atravessam dado território, com base, principalmente, nos seguintes fatores: (i) geografia (cadeias, rios, desertos etc.) que dificulte influxos econômicos externos e efluxos para além-fronteiras; (ii) distância física de outros Estados; (iii) diferenças de idioma com outros Estados; (iv) signos culturais familiares aos seus habitantes, mas estranhos a outros povos; (v) etnia; (vi) poder dos trustes nacionais e corporações estatais; (vii) fiscalização aduaneira e controle de fronteiras eficaz; e (viii) mínima densidade demográfica.

${ }^{2}$ Cf. R. Pacheco, Inserção na economia global: uma reapreciação, pp. 8-9.

${ }^{3}$ Cf. R. Pacheco, Inserção na economia global: uma reapreciação, pp. 9-10.
} 
melhor alocação dos recursos com menores custos. Essa maximização da eficiência denomina-se global outsourcing. ${ }^{4}$

Em matéria de tributação, essa é a forma de atuação das sociedades-base. $\mathrm{Na}$ prática, uma determinada empresa pode desmembrar uma atividade, ciclo ou processo produtivo por diversas jurisdições, de forma que a tributação total da MNE importe reduzida quando comparada àquela que decorreria da localização das ações em um só território. 5

A mudança da economia geopolítica para a global marca a queda de barreiras étnicas, culturais, comunicacionais e comerciais, tendo sido bem descrita por André Arnaud, ao resumir o conflito entre os pressupostos da modernidade - "regulação social se faz primeiramente pelo direito e (...) o Estado é soberano e tem poder exclusivo sobre o direito" - e da pós-modernidade - "nem toda a regulação social passa pelo direito (...) o Estado perde terreno na sua soberania, inclusive no que diz respeito ao direito."6

Se o Estado perde, as MNEs ganham terreno e poder decisório quanto à alocação de seus recursos, cuja destinação tem sido disputada, nos últimos anos, por praticamente todos os países. ${ }^{7}$ Cada qual procura mostrar-se mais atrativo a fim de conquistar o capital

\footnotetext{
${ }^{4}$ Cf. R. Pacheco, Inserção na economia global: uma reapreciação, pp. 10-11.

${ }^{5}$ XAVIER, Alberto. Direito tributário internacional do Brasil. 6. ed. Rio de Janeiro: Forense, 2005, pp. 343344. Como exemplo, ter-se-ia sociedades de montagem nas Bahamas, comercialização de produtos e controle de marcas e patentes em Luxemburgo e o transporte marítimo efetuado pelas sociedades de navegação da Libéria.

${ }^{6}$ ARNAUD, André-Jean. $O$ direito entre modernidade e globalização: lições de filosofia do direito e do Estado.Tradução de Patrice Charles Wuillaume. Rio de Janeiro: Renovar, 2000, pp. 192-193. No mesmo sentido, Fernando Scaff, para quem "Um país não é mais soberano como antes, ctejado com a época em que Jean Bodin cunhou o conceito. A soberania encontra-se mais relativizada do que nunca." V. SCAFF, Fernando Facury. O direito tributário das futuras gerações. In: MARTINS, Ives Gandra da Silva (coord.), Tributação na internet. São Paulo: Centro de Extensão Universitária/Revista dos Tribunais, 2001( Pesquisas tributárias: nova série 7), p. 405.

${ }^{7}$ A título de ilustração, podem ser citados os casos da Intel na Costa Rica e da Ford no Brasil. No primeiro, a Intel não contemplava, inicialmente, a Costa Rica, como uma das possibilidades de alocação de investimento. Foram necessárias diversas obras de melhoria em infra-estrutura, assim como a oferta de incentivos fiscais isenção integral do imposto de renda nos oito primeiros anos e isenção de $50 \%$ nos quatro anos subseqüentes - para que a Intel optasse pela Costa Rica em detrimento do Brasil, Chile, Indonésia, México e Tailândia, que também concorriam para atrair a empresa. Cf. SILVA, Mauro. Da competição à cooperação tributária internacional: aspectos jurídicos da promoção do desenvolvimento nacional num cenário internacionalizado. Tese de Doutorado - Faculdade de Direito da USP, São Paulo, 2009, pp. 41-42. O caso da Ford tratou de situação diversa, pois a competição para atrair a empresa envolveu entes subnacionais brasileiros, Rio Grande do Sul e Bahia, e a Argentina. Embora o Rio Grande do Sul tenha sido cogitado, inicialmente, para receber o investimento, ampla oferta de incentivos fiscais conduziu a planta da Ford para a Bahia. Os incentivos abrangeram impostos federais (sobre importação, produtos industrializados e renda) e estaduais (ICMS), além da concessão de terreno para instalação da fábrica e de um crédito adicional de US\$ 100 milhões a custos baixos. Cf. UNCTAD. Tax incentives and foreign direct investment: a global survey. ASIT Advisory Studies $\mathrm{n}^{\mathrm{o}}$ 16. New York e Geneva, 2000, p. 24 . Disponível em: http://www.unctad.org/en/docs/iteipcmisc3_en.pdf. Acesso em $20 \mathrm{dez} 2011$.
} 
estrangeiro, que poderá ser de curto prazo - maturidade inferior a um ano - ou de longo prazo - maturidade superior a um ano. ${ }^{8}$

Capitais estrangeiros de longo prazo dividem-se em empréstimos e investimentos. ${ }^{9}$ Os primeiros são remunerados por meio de juros e os últimos, por dividendos ou ganhos de capital, costumando variar o tratamento tributário conferido por determinado ordenamento a cada uma dessas espécies de rendimento.

Os investimentos internacionais, geralmente considerados capitais de longo prazo, subdividem-se em investimento direto - IED e investimento de portfólio. Enquanto o primeiro envolve a aquisição de ações ou quotas sociais no exterior com o fito de desempenhar um papel de controle, tomada de decisões, sobre a empresa; o último não visa a controlar a empresa estrangeira, incluindo diversidade de ativos ou instrumentos financeiros como ações, bônus, debêntures, títulos privados e públicos. ${ }^{10}$

Essa distinção é fundamental para o direito tributário internacional, pois dela depende a aplicação de regras CFC - controlled foreign corporations, ${ }^{11}$ cujo fim está em evitar o diferimento da tributação sobre lucros não distribuídos pela empresa localizada no exterior. Entende-se que deve haver a capacidade de decidir sobre o destino dos lucros da investida, razão pela qual se exige um patamar de participação como sinônimo de controle, o que é variável de acordo com os ordenamentos nacionais.

Regra geral, a participação superior a 50\% do capital votante da empresa designa um investimento estrangeiro direto - IED. Dificuldades surgem quando a participação minoritária indica controle, de modo que a prática internacional consagrou a participação

\footnotetext{
${ }^{8}$ GONÇALVES, Reinaldo et al. A nova economia internacional: uma perspectiva brasileira. Rio de Janeiro: Campus, 1998, p.122. Essa distinção não é absoluta, já que instrumentos de curto prazo (créditos comerciais) podem ser renovados por longos períodos, assim como um título de longo prazo (bônus) pode ser comprado antes da data do vencimento. Na verdade, até mesmo empresas inteiras podem ser adquiridas quase de forma imediata (fusões e aquisições).

${ }^{9}$ Também se deve considerar certa fluidez nessa distinção, uma vez que nada impede a securitização de um contrato de empréstimo cujo título represente um investimento. Cf. R. Gonçalves et al, A nova economia internacional: uma perspectiva brasileira, p. 122.

${ }^{10} \mathrm{Cf}$. R. Gonçalves et al, A nova economia internacional: uma perspectiva brasileira, p. 123. Edwards e Mitchell pontuam que investimentos estrangeiros subdividem-se em diretos e de portfólio. Investimentos diretos (IED) seriam aportes de capital, realizados com objetivos de longo prazo, que representam participação no capital de empresas estrangeiras de, no mínimo, 10\%. Geralmente são utilizados para a expansão ou aquisição de novas subsidiárias no exterior. Já os investimentos estrangeiros de portfólio (IEP) seriam os investimentos em títulos externos, privados ou públicos, além de pequenas participações em empresas até o limite de $10 \%$. Usualmente são realizados com objetivos de curto prazo. Cf. C. Edwards e D.J. Mitchell, Global tax revolution: the rise of tax competition and the battle to defend it., p. 18.

${ }^{11}$ V. tópico IV.3.2.
} 
mínima de $10 \%$ do investidor estrangeiro no capital votante da empresa como linha divisória entre investimentos de portfólio e IED. ${ }^{12}$

Embora os investimentos de portfólio representem fluxos internacionais de capital para um Estado receptor, a sensibilidade ao risco os torna essencialmente voláteis, o que os coloca em posição secundária para os fins desta tese. Com efeito, as análises seguintes ocupar-se-ão, principalmente, do IED, cabendo indagar se a tributação da renda é capaz de influir na alocação do capital estrangeiro e quanto. Afinal, a concorrência tributária internacional, tão propalada desde o Relatório 1998 da OCDE, ${ }^{13}$ se traduz pela concessão geral de incentivos fiscais para atração do IED.

Até que Stephen Hymer defendesse sua tese de doutorado no MIT, em 1960, acreditava-se que o principal fator de localização de um fluxo de investimento estaria, simplesmente, em sua taxa de retorno. Hymer lançou luz ao tema, conferindo importância prioritária às análises de fatores específicos espaciais - atributos típicos de cada mercado e de fatores específicos da propriedade - tais como tamanho da empresa, vantagem tecnológica, economia de escala, capacidade gerencial, acesso a fonte de insumos e mercado de capitais. $^{14}$ Este foi o ponto inicial para a moderna teoria $d a$ internacionalização da produção, segundo a qual, os residentes de determinado Estado teriam três alternativas para acessar bens ou serviços oriundos do exterior, a saber:

(i) comércio internacional: exige o deslocamento de bens e serviços;

(ii) relação contratual: o residente assume a condição de agente produtor em lugar da empresa estrangeira. Neste caso, poderá haver, por exemplo, transferência de tecnologia; e

(iii) investimento externo direto: pressupõe a instalação física da empresa estrangeira no Estado receptor. ${ }^{15}$

\footnotetext{
${ }^{12}$ Cf. R. Gonçalves et al, A nova economia internacional: uma perspectiva brasileira, p. 124. Informam os autores que essa é a recomendação do Fundo Monetário Internacional - FMI, em seu Manual de Balanço de Pagamentos. Os EUA, ao inovarem com a criação das regras CFC em seu Internal Revenue Code, Subpart F, em 1962, já previam a necessidade, para a aplicação dessas regras, de que os investidores se qualificassem como US shareholders, o que significava, justamente, um mínimo de participação de $10 \%$ do capital votante da empresa estrangeira. Neste sentido, Doernberg dá um exemplo em que onze norte-americanos detêm a integralidade de uma empresa no exterior com a mesma participação. Embora possuam mais de $50 \%$ do capital votante da investida, a esta não se aplicarão as regras CFC, já que não há sequer um US shareholder. V. R. Doernberg, International taxation in a nutshell. $5^{\text {th }}$ ed. Saint Paul, Minn: West Group, 2001, p. 296.

${ }^{13}$ ORGANIZAÇÃO PARA COOPERAÇÃO E DESENVOLVIMENTO ECONÔMICO. The OECD's Project on Harmful Tax Practices: The 1998 Report. Disponível em: www.oecd.org. Acesso em 02 nov 2011. Doravante Relatório 1998.

${ }^{14}$ GONÇALVES, Reinaldo. A internacionalização da produção: uma teoria geral? Revista de Economia Política, v. 4, nº 1, jan-mar/1984, p. 16. Disponível em : http://www.rep.org.br/pdf/13-7.pdf. Acesso em 20 dez 2011.

${ }^{15}$ Cf. R. Gonçalves et al, A nova economia internacional: uma perspectiva brasileira, pp132-135.
} 
Como a teoria da internacionalização da produção valoriza as especificidades dos países e das empresas, cumpre bem definir aquelas que participam da economia mundial em busca da eficiência máxima, chegando a decompor seu processo produtivo por diversos países para obter ganhos de escala: as multinacionais ou transnacionais.

Fabio Nusdeo destaca a empresa multinacional como um fenômeno da nova economia global. Aduz que transnacional seria denominação mais adequada, posto que tais empresas transcendem as fronteiras nacionais para atuarem, coordenada $\mathrm{e}$ harmonicamente, sob uma estratégia central. ${ }^{16}$

Também Heleno Tôrres critica a expressão empresa multinacional ao argumento de que, em verdade, tratar-se-ia de uma empresa de múltiplas residências, mas não forçosamente nacionalidades variadas, para arrematar que à empresa transnacional não corresponde qualquer forma jurídica específica, conferindo-se o predicado multinacional à empresa mais pelas "repercussões que o modo de atuação transnacional engendra (...) do que por qualquer outro fator.",17

Do ponto de vista econômico, pode-se bem definir a empresa transnacional como "a empresa de grande porte que possui e controla ativos produtivos em pelo menos dois países." ${ }^{18}$ Inobstante o fato de qualquer empresa apresentar suas vantagens específicas, é nas empresas transnacionais que se apresentam os maiores estoques de vantagens comparativas no atual contexto global. Afinal, elas detêm, significativamente, capital, tecnologia, recursos humanos, gerenciais, mercadológicos e organizacionais. ${ }^{19}$

A tributação impacta a alocação do investimento, constituindo-se em um fator espacial (não um fator específico da propriedade) a ser observado. Assim é porque os tributos encontram-se ligados à jurisdição de destino do IED.

\footnotetext{
${ }^{16}$ NUSDEO, Fábio. Curso de Economia: introdução ao direito econômico, 2. ed.. São Paulo: Revista dos Tribunais, 2000, p. 330.

${ }^{17}$ Cf. H. Tôrres, Pluritributação internacional sobre as rendas de empresas, pp.178-179. Em sentido oposto, José Carlos de Magalhães alega que o predicado multinacional, conferido às "empresas que atuam em diversas partes do mundo, em estratégia de integração e de coordenação de atividades, pressupõe a existência de uma entidade que atua por meio de pessoas jurídicas de nacionalidades diversas.." Há, neste caso, uma sobrevaloração do termo nacionalidade, já que as multinacionais atuariam por meio de subsidiárias com nacionalidades diferentes, dando ensejo a eventuais problemas de difícil solução caso haja conflito de interesses "entre os países dos quais são nacionais." V. J. C. Magalhães, Direito Econômico Internacional. Curitiba: Juruá, 2006, pp. 221-222. Para o direito tributário internacional, o vínculo pela residência já desencadeia os efeitos decorrentes da conexão pessoal com determinada jurisdição, restando nacionalidade como opção para pouquíssimos países, com destaque para os EUA. Para efeitos desse trabalho, adotar-se-á a sinonímia entre as expressões empresas multinacionais ou empresas transnacionais, com preferência por esta última.

${ }^{18} \mathrm{Cf}$. R. Gonçalves et al, A nova economia internacional: uma perspectiva brasileira, p.135.

${ }^{19} \mathrm{Cf}$. R. Gonçalves et al, A nova economia internacional: uma perspectiva brasileira, p.135.
} 
Em geral, são fatores espaciais, avaliados pelos atores globais na decisão da localização do investimento, aqueles relacionados: ${ }^{20}$

(i) aos custos de disponibilidade de fatores de produção: arrendamento de terrenos, construção civil, matéria-prima, mão-de-obra, tarifas energéticas, infra-estrutura de transporte (portos, aeroportos e malha rodoviária);

(ii) ao processo produtivo: condições naturais, grau de organização de cadeias produtivas;

(iii) à comercialização: potencial de vendas, distâncias física até o consumidor;

(iv) a disposições estatais: ônus tributário, controle alfandegário, ordem econômica (salvaguarda da concorrência, disposições constitucionais, risco de intervenção, confisco), incentivos fiscais;

(v) a fatores estratégicos.

Como se percebe, incentivos fiscais representam apenas um subfator de influência na decisão de fluxo de IED, assim como o ônus tributário. Se considerarmos o fenômeno da global outsourcing que desterritorializou o investimento, fica bastante difícil para um Estado determinar e justificar a adoção de uma política de valoração de determinado fator locacional que lhe torne mais atrativo para o IED. Isso porque seria necessário dimensionar a importância relativa de cada fator locacional segundo a visão do investidor estrangeiro, dados esses nem sempre disponíveis ao Estado.

Segundo dados divulgados pelo Banco Mundial, os fluxos de IED sofreram drástica queda na década de 1980, ocasião em que o Brasil vivia alta inflação, crise da dívida e instabilidade política. A situação não se alterou a ponto de merecer registro até 1994, quando a estabilização dos preços passou a favorecer o ingresso de IED. O período que se estendeu até a desvalorização em 1999 registrou forte reação, passando, o País, a receber significativos influxos de investimentos. ${ }^{21}$

Com relação aos fluxos mundiais de investimentos registrados em 2010, o Relatório sobre Investimentos Mundiais da UNCTAD aponta o Brasil como o $5^{\circ}$ colocado

${ }^{20}$ Cf. R. Pacheco, Inserção na economia global: uma reapreciação, p. 31.

${ }^{21}$ Dentre os fatores apontados para a melhoria dos influxos de IED na década de 90, encontram-se a queda significativa das tarifas sobre as importações (média de 51\% em 1987 caiu para 12,5\% em 1995); estabilização da moeda; estímulo ao capital estrangeiro por meio da abertura da concessão de serviços públicos, assim como tratamento igualitário conferido a empresas brasileiras controladas por residentes no Brasil e empresas brasileiras controladas por estrangeiros. BANCO MUNDIAL e CORPORAÇÃO FINANCEIRA INTERNACIONAL. Barreiras jurídicas, administrativas e políticas aos investimentos no Brasil, v. 1, junho 2001, pp.10-13. Disponível em: http://siteresources.worldbank.org/BRAZILINPOREXTN/Resources/3817166-1185895645304/40441681186403960425/05V1.pdf. Acesso em 15 dez 2011. 
na lista dos países destinatários de IED. ${ }^{22}$ Terá sido o bom resultado brasileiro reflexo direto de uma política de incentivos fiscais em matéria de tributação da renda? Acaso se mostra concludente que o Brasil tenha atuado, neste ponto, de forma planejada, pondo em prática uma ampla e arquitetada política indutora consoante à legislação do imposto de renda? Ou seria mais lógico supor que a atração de IED tenha resultado, entre outros fatores, de pontuais incentivos trazidos pelo legislador, somados a um quê de estabilidade e modernização da legislação do imposto de renda pós-real?

Independente do resultado das análises subseqüentes, a decisão do legislador - seja por uma política indutora ou por atos isolados - deverá ser avaliada em face das ordens tributária e econômica, não somente para averiguar se se presta ao fim a que se propõe (atração de IED), como também se está conforme aos ditames constitucionais.

\section{II.1.2 Conceito de Concorrência Tributária Internacional}

A concorrência tributária internacional é um dos fenômenos resultantes da atual conjuntura da ordem internacional. As alterações promovidas pelos fluxos de comércio e de investimento de capitais promoveram o contágio de políticas e práticas adotadas internamente além-fronteiras. Essas alterações ganham crescente dinamismo pelos impulsos do avanço tecnológico, transformando, radicalmente, o cenário da ordem tributária de cerca de meio século atrás.

Os Estados, até o final da primeira década do séc. XXI, engajaram-se em um processo de integração econômica de proporções variadas entre o regional, continental e global, na busca por riquezas e desenvolvimento. Essa busca tornou-se ainda mais necessária em virtude da crise financeira no fim da referida década. Nesse contexto, as políticas de determinado Estado constrangem ou influenciam, cada vez mais, as de outros Estados, de modo que é da diferença entre essas políticas nacionais em termos de tributação, que resulta o aformoseamento de um dado sistema tributário cujo fim precípuo é atrair fatias maiores da base mundial de tributação, exportando algo de sua carga tributária. $^{23}$

22 UNCTAD, World Investment Report 2011. Disponível em: http://www.unctad.org/Templates/webflyer.asp?docid=15189\&intItemID=2068\&lang=1\&mode=downloads. Acesso em 10 out 2011.

${ }^{23}$ Cf. Vito Tanzi, Globalization, tax Competition by the future of tax systems, p. 23. 
Sob o ponto de vista jurídico, os Estados escudam-se na soberania para agirem tais quais agentes privados em busca de mercados, valendo-se da inexistência de um regramento específico em matéria concorrencial, o que levou Joachim Lang a afirmar que uma “ordem internacional voltada à regulação da concorrência ainda está no jardim de infância." 24

Seria, pois, a concorrência tributária internacional, a competição entre os Estados soberanos para atrair investimentos (diretos e de portfólio) e "empresas multinacionais com funções empresariais específicas". ${ }^{25}$ Pode ser definida, ainda, por pressão internacional na determinação da política fiscal de um Estado, não apenas pela concessão de incentivos tributários, mas também de subvenção direta. ${ }^{26}$

Levado ao extremo, o conjunto de políticas fiscais nacionais voltadas à atração de capital poderia conduzir à uma corrida para o fundo (race to the bottom), com significativo declínio de receitas advindas da tributação do capital, capaz de fazê-la tender a zero. Este o pensamento da chamada teoria tradicional da concorrência tributária (tax competition), que predominou nos anos 90.

Genschel confronta a idéia então dominante ao asseverar, suportado empiricamente, não haver correlação entre concorrência tributária e desgaste da base de tributação sobre o capital ou mesmo sobre as receitas em geral. ${ }^{27}$ Em suas conclusões, Genschel sustenta que nenhuma das posições seria definitiva, pois não havia evidências de perdas significativas de receitas, tampouco de alteração da base tributária do capital (alta mobilidade) para consumo ou trabalho (menos móveis) no ambiente da OCDE. Contudo, afirma que a concorrência tributária reprime, sim, a política de tributação dos Estados. ${ }^{28}$

\footnotetext{
${ }^{24}$ LANG, Joachim. A tributação das empresas no contexto da concorrência internacional. In: ZILVETI, Fernando Aurélio (coord.), Direito Tributário Atual 25. São Paulo: Dialética, 2011. p. 23. O autor noticia que a OCDE tem se ocupado com o tema, assim como o Conselho Europeu de Economia e Finanças, que editou um Código de Conduta para Tributação de Empresas para uma concorrência tributária justa.

${ }^{25}$ RODI, Michael. Concorrência tributária internacional por investimentos. In: COSTA, Alcides Jorge; SCHOUERI, Luís Eduardo e BONILHA, Paulo Celso Bergstrom (coord.), Direito Tributário Atual 21. São Paulo: Dialética, 2007. pp. 126-7. O autor cita um estudo que teria descoberto um valor médio de elasticidade de carga tributária de $-3,3 \%$, ou seja, a cada redução da tributação em $1 \%$ corresponderia um incremento de $3,3 \%$ de IED.

${ }^{26} \mathrm{Cf}$. A. Elali, Incentivos fiscais internacionais - concorrência fiscal, mobilidade financeira e crise do Estado, pp. 155-156.

${ }^{27}$ Genschel elenca inter alia Maystadt, Lafontaine e Strauss-Kahn, Scharpf, Frey, Steinmo como defensores da visão tradicional e, em contrapartida, cita Garret, Kirchgässner e Pommerehne, Quinn e Swank, cujas análises empíricas não sugeriram uma race to the bottom quanto à tributação do capital. Cf. GENSCHEL, Phillip, Globalization, tax competition, and the fiscal viability of the welfare state. Working papers, Max Planck Institute for the Study of Societies, 2001, pp.1-2. Disponível em: http://www.mpifg.de/pu/workpap/wp01-1/wp01-1.html. Acesso em 04 nov 2011.

${ }^{28}$ Cf. P. Genschel, Globalization, tax competition, and the fiscal viability of the welfare state, pp. 2-3.
} 
Aferir com exatidão os efeitos da tributação sobre o fluxo de capital é questão complexa que divide pesquisadores. Michael Rodi noticia os resultados alcançados por Krogstrup: na UUEE, a relação entre o IRPJ e o PIB (IRPJ/PIB) aumentou nas últimas três décadas, porém, a relação do mesmo imposto com a arrecadação total (IRPJ/arrecadação total) vem decrescendo desde 1965. ${ }^{29}$ Embora tais dados possam sugerir que o imposto de renda corporativo sinta algum efeito da concorrência tributária internacional, Rodi combate essa conclusão. Para ele, em nada importa a tributação do IRPJ para a decisão de alocação do investimento. Importa, sim, para a decisão sobre a demonstração dos lucros. ${ }^{30}$ A essa conclusão também parecem chegar Bénassy-Quéré; Fontagne e Lahreche-Revil, ao sustentarem que os mecanismos de preços de transferência e os contratos de mútuo entre empresas do mesmo grupo facilitam a alteração dos lucros para jurisdições de menor tributação, independente do local de produção desses lucros. ${ }^{31}$

Devem-se, por oportunas, registrar as ilações a que chegaram Bénassy-Quéré; Fontagne e Lahreche-Revil: (i) a concorrência tributária não precisará conduzir a uma tributação zero. Ao contrário, países atrativos saberão explorar suas vantagens locacionais, mantendo seus índices de arrecadação; (ii) há uma sensibilidade assimétrica do IED com relação ao diferencial do imposto de renda corporativo na fonte e na residência do investidor. Enquanto alíquotas mais baixas na fonte que na residência não estimulam significativamente o fluxo de IED; alíquotas mais altas tendem a desestimulá-lo com mais intensidade. Assim, países de tributação elevada não deveriam se sentir estimulados a reduzir a tributação por meio de incentivos fiscais, mas considerar que o IED responde também ao potencial do mercado e aos bens públicos disponíveis como contrapartida pelo ônus tributário suportado. Ainda que por outra via, parecem corroborar a teoria de Hymer. $^{32}$

Não se pode desprezar o avanço da integração, uma vez que reduz barreiras econômicas, tecnológicas e institucionais ao investimento transnacional. Este, por seu turno, deve se tornar cada vez mais sensível a diferenças nas regras do imposto de renda corporativo entre os países. Embora fatores não tributários devam permanecer dominantes,

\footnotetext{
${ }^{29}$ Cf. M. Rodi, Concorrência tributária internacional por investimentos,p. 130.

${ }^{30} \mathrm{Cf}$. M. Rodi, Concorrência tributária internacional por investimentos,p. 130.

${ }^{31}$ Cf. BÉNASSY-QUÉRÉ, Agnès; FONTAGNE, Lionel Gerard e LAHRECHE-REVIL, Amina. How Does FDI React to Corporate Taxation? In: International Tax and Public Finance, V. 12, $\mathrm{n}^{\circ}$ 5, 2005 , p.3 Disponível em: http://ssrn.com/abstract=1260868. Acesso em 15 set 2011.

${ }^{32}$ Cf. A.Bénassy-Quéré, L.G.Fontagne e A. Lahreche-Revil, How Does FDI React to Corporate Taxation?, p.19.
} 
as diferenças quanto às regras de tributação deverão influenciar cada vez mais a decisão de localização das MNEs. ${ }^{33}$

II.1.3 Aspectos positivos e negativos da concorrência tributária internacional

A favor da concorrência tributária tornou-se conhecida a teoria de Charles Tiebout, de 1956, A pure theory of local expenditures. Segundo Tiebout, acréscimo de bem-estar resultaria da concorrência tributária e da concorrência de entidades econômicas no mercado. Ademais, as pessoas físicas e empresas poderiam se fixar onde houvesse melhor relação entre ônus tributário e serviços e bens públicos ofertados em contrapartida. Esta é uma concepção raramente defendida em caráter geral. Afinal, não pode valer para todos os Estados, uma vez que a idéia de competição, concorrência, enseja perdedores - Estados maiores- e vencedores - Estados menores. ${ }^{34}$

Outro aspecto positivo da concorrência tributária internacional resulta da limitação que impõe ao poder de tributar dos Estados e, por conseguinte, ao gasto público, dada a necessidade de manter o equilíbrio orçamentário. ${ }^{35}$

Há, porém, fundados receios quanto à concorrência tributária internacional. A perda de receitas pela baixa imposição ameaça o bem-estar social. Na mesma esteira, a pressão pela redução da tributação pode comprometer as finanças públicas, desequilibrando o orçamento e estimulando a dívida pública.

Aspecto delicado é a inegável redução de soberania dos Estados, que, isoladamente, levam em conta as regras vigentes em outros ordenamentos tributários para a estruturação dos seus próprios. É o caso típico do dilema do prisioneiro, cujos resultados mais vantajosos somente poderão decorrer da mútua cooperação entre os interessados, enquanto ações isoladas beneficiarão somente uma das partes, gerando dificuldades para as outras. ${ }^{36}$ Como o interesse geral está em atrair capital, os Estados buscam possíveis vantagens para si em detrimento dos demais, o que, considerado coletivamente, pode acarretar uma

\footnotetext{
${ }^{33}$ OCDE, Taxing profits in a global economy- domestic and international issues, OECD, Paris, 1991, ISBN 92-64-13596-0, p. 21. V. também BÉNASSY-QUÉRÉ, Agnès; FONTAGNE, Lionel Gerard e LAHRECHEREVIL, Amina. How Does FDI React to Corporate Taxation? In: International Tax and Public Finance, V. 12, no 5, 2005. Disponível em: http://ssrn.com/abstract=1260868.

${ }^{34}$ Cf. M. Rodi, Concorrência tributária internacional por investimentos, pp. 127-128. Neste mesmo sentido, A. Elali, Incentivos fiscais internacionais, p.157.

${ }^{35} \mathrm{Cf}$. M. Rodi, Concorrência tributária internacional por investimentos, pp.127-128.

${ }^{36}$ COOTER, Robert; ULLEN, Thomas. Direito e economia, 5. ed. Porto Alegre: Bookman, 2010, pp.56-59.
} 
corrida para o fundo, produzindo externalidades fiscais (spillover effects) ${ }^{37}$ e concorrendo para a redução do bem-estar geral. ${ }^{38}$

$\mathrm{Na}$ prática, os Estados sentem-se temerosos em alterar regras de tributação e gerarem saída de capitais, perdendo arrecadação. Assim, acabam não tributando determinadas cédulas de renda, como juros e dividendos, mas alterando a incidência da tributação. Vito Tanzi alerta que essa faceta da concorrência tributária pode levar à degradação fiscal (tax degradation), que força os Estados a reduzirem sua principal fonte de receitas, a fim de permanecerem competitivos no cenário internacional. ${ }^{39}$

Há, ainda, um aspecto voltado à justiça fiscal. Por este prisma, a concorrência tributária internacional promoveria a alteração da tributação sobre o capital, por ser uma base de alta mobilidade, para outras menos móveis como consumo, trabalho e imóveis, o que seria socialmente injusto. ${ }^{40}$

II.1.4 Paraísos fiscais e regimes de tributação privilegiados

\section{II.1.4.1 Relatório da OCDE sobre concorrência tributária nociva -1998}

A intensa busca pelo investidor leva os Estados a tornarem seus sistemas tributários mais atrativos. Contudo, em um ambiente globalizado, por vezes medidas domésticas impactam noutros sistemas nacionais. Embora difícil definir os exatos contornos que segregam a justa ou aceitável competitividade da nociva, pode-se afirmar que esta última se manifesta quando tais medidas domésticas distorcem outros sistemas tributários e afetam, em último grau, a confiança dos contribuintes naquele sistema.

Dentre as práticas mais acirradas na concorrência tributária encontram-se aquelas levadas a efeito pelos paraísos fiscais e regimes fiscais privilegiados, que estão no cerne das discussões acerca do tema desde a publicação do Relatório 1988 da OCDE.

Os Estados, desejosos de escudar suas economias dos efeitos da concorrência fiscal nociva, passaram a adotar contramedidas variadas, tanto em caráter unilateral, como em

\footnotetext{
${ }^{37}$ Para um ótimo estudo sobre os efeitos das externalidades sobre a concorrência tributária internacional, v. Mauro Silva, Da competição à cooperação tributária internacional, pp.24-27.

${ }^{38}$ Cf. M. Rodi, Concorrência tributária internacional por investimentos, p. 129.

${ }^{39} \mathrm{Cf}$. V. Tanzi, Globalization, tax Competition by the future of tax systems, p. 30.

${ }^{40} \mathrm{Cf}$. P. Genschel, Globalization, tax competition, and the fiscal viability of the welfare state, p. 2; e M. Rodi Concorrência tributária internacional por investimentos, p. 128.
} 
arranjos bilaterais. Todavia, a eficácia dessas medidas sofre limitações, já que visam a combater um problema de natureza global.

Normalmente, medidas unilaterais são mais facilmente implantadas, uma vez que não precisam de manifestação alienígena. Em contrapartida, limitam a ação das autoridades tributárias aos seus contornos jurisdicionais e podem elevar os custos administrativos para monitorar as diversas práticas nocivas e conseqüente aplicação de contramedidas. Há, ainda, o risco de medidas unilaterais descoordenadas elevarem os custos dos contribuintes.

Outro fator de limitação das medidas puramente unilaterais decorre da tributação imposta sobre residentes, a fim de neutralizar os efeitos da concorrência desleal no país de fonte. Tal medida, se não adotada por outros países, levará a uma desvantagem competitiva dos próprios residentes em suas atividades econômicas, o que, por certo, as tornará impraticáveis.

Em vista disso, o sucesso da neutralização da concorrência fiscal nociva depende, em larga escala, de ações internacionalmente coordenadas, dadas as características hodiernas de mobilidade do capital. Em seu Relatório 1998 e atualizações, ${ }^{41}$ a OCDE conclamou membros e não-membros para intensificarem a cooperação internacional, por meio de recomendações ${ }^{42}$ segmentadas em três frentes:

(i) concernentes à legislação doméstica: visando a aumentar a eficácia das contramedidas à nocividade já vigentes na legislação dos países, os Estados deveriam considerar a adoção de regras $C F C$ - os que já a possuíssem, deveriam se certificar da consistência de sua aplicação-; adotar regras assecuratórias de que a renda de fonte estrangeira, beneficiada por incentivos caracterizados por prática nociva, não se qualifique para o método da isenção para eliminar a bitributação da renda; se abster de aplicar suas regras sobre preços de transferência de um modo que venha a configurar concorrência nociva. $^{43}$

Quanto ao acesso a informações bancárias para fins tributários, os países deveriam rever suas leis e práticas sobre o assunto no contexto da concorrência fiscal nociva, com vistas a remover impedimentos de acesso a tais informações pelas autoridades fiscais. Reuven Avi-Yonah relembra que, na seqüência desta recomendação, a OCDE publicou um

\footnotetext{
${ }^{41}$ A OCDE emitiu relatórios progressivos sobre concorrência fiscal nociva em 2000, 2001 e 2004.

${ }^{42}$ Anexo I do Relatório 1998.

${ }^{43}$ Para maiores informações, v. OCDE, Transfer Pricing Guidelines for Multinational Enterprises and Tax Administrations. A primeira versão remonta a 1995; a última, a 18 de agosto de 2010.
} 
segundo relatório específico a respeito de legislação de sigilo bancário em $2000,{ }^{44}$ que, além de reforçar a recomendação supra, estimulava o fisco a uma efetiva troca de informações. $^{45}$

(ii) concernentes aos acordos de bitributação: com o fim de assegurar que os acordos não favoreçam, inadvertidamente, a práticas nocivas e estimulem a efetiva troca de informações entre os signatários, mormente sobre transações em paraísos fiscais e regimes privilegiados. ${ }^{46}$

No âmbito convencional, dever-se-ia considerar a adoção de cláusulas LOB, limitando os benefícios de um acordo de bitributação a entidades ou rendas não cobertas por práticas concorrenciais nocivas. No mesmo contexto, caberia aos países encerrar suas convenções com paraísos fiscais e não assinar novas no futuro.

(iii) concernentes à intensificação da cooperação internacional: reforçadas por diretrizes que sugerem novas maneiras de combater, coletivamente, as práticas tributárias nocivas. Nesta esteira, os países deveriam empreender programas de execução coordenados, como, por exemplo, auditorias simultâneas, projetos específicos de troca de informação, atividades de treinamento conjunto e outras.

\section{II.1.4.2 Conceito de paraísos fiscais ${ }^{47}$}

A preocupação dos países em definir paraísos fiscais (tax havens) com maior rigor é recente. A matéria passou a integrar normas domésticas mais maciçamente nos anos 90, a despeito de não se tratar de nenhuma inovação. Com efeito, os primórdios dos paraísos

\footnotetext{
${ }^{44}$ OCDE, Improving Acess to Bank Information for Tax Purposes, 2000.

${ }^{45}$ Cf. Reuven S. Avi-Yonah, The OECD Harmful Tax Competition Report: A Tenth Anniversary Retrospective (August 1, 2008). University of Michigan Public Law Working Paper No. 115. Disponível em: http://ssrn.com/abstract=1194942. Acesso em: 05 out 2011.

${ }^{46}$ Embora já a versão original da Convenção Modelo da OCDE trouxesse a previsão de troca de informações em seu artigo 26, este foi um tema substancialmente ampliado ao longo das diversas revisões do modelo (última revisão em 22 de julho de 2010). Materialmente, foi ampliado o leque dos compromissos de troca de informações entre os Estados na esfera da assistência recíproca em assuntos tributários de repercussão civil e criminal. Todos os membros da OCDE atualmente aceitam o teor do artigo 26 da Convenção Modelo sem quaisquer reservas, já que Áustria, Bélgica, Luxemburgo e Suíça retiraram as suas em março de 2009. Cf. OCDE, Tax Co-operation 2009 - Towards a level playing field. Disponível em: http://www.oecd.org/dataoecd/41/58/43597404.pdf. Acesso em 15 set 2011.

${ }^{47}$ A menos que se ressalve, o termo paraísos fiscais, doravante, englobará tanto países com tributação favorecida como regimes fiscais privilegiados inseridos em dada jurisdição.
} 
fiscais remontam à Grécia Antiga, quando pequenas ilhas vizinhas a Atenas protegiam mercadorias para adentrarem clandestina e posteriormente no país, já que a famosa cidade tributava as importações e exportações a uma alíquota de $2 \% .{ }^{48}$

O regresso histórico tem objetivo prático, uma vez que nem sempre foi o imposto de renda o alvo central dos privilégios ofertados pelos países ou jurisdições e nem mesmo o contexto da concessão dos mesmos envolveu competição interestatal. De fato, ainda hoje, os paraísos fiscais podem ser utilizados para fins diversos, inclusive não tributários, como lavagem de dinheiro e terrorismo.

Baker ensina que, desde a Idade Média, os privilégios fiscais foram concedidos com finalidade indutora. Objetivos desenvolvimentistas muitas vezes justificaram a concessão de incentivos fiscais. Foi assim no povoamento de colônias norte-americanas ermas ou mesmo nas cidades ucranianas em que os artesãos usufruíam de isenção fiscal concedida pelos reis. $^{49}$

Até meados do século XX, não havia uma conotação negativa sobre as práticas de paraísos fiscais. O cenário foi alterado por fenômenos que irromperam naquela ocasião e chegaram aos nossos dias, como, por exemplo, elevados ônus fiscais do pós-guerra, acordos de bitributação e globalização. Todos esses motivaram a proliferação de paraísos fiscais, impactando crescentemente as operações transfronteiriças de comércio e investimento e causando desvio das rendas para jurisdições de baixa ou nenhuma imposição fiscal. ${ }^{50}$

Mas esses efeitos seriam suficientes para predicar a concorrência praticada por paraísos fiscais como nociva? A resposta parece ser negativa. De fato, paraísos fiscais podem ser vistos como instrumento exterior de proteção contra cargas tributárias elevadas, se não confiscatórias. Ademais, nada garante que a erosão da base tributária de um país decorra, seguramente, da concorrência fiscal nociva e não de políticas públicas mal implantadas internamente, ou mesmo de uma concorrência limpa. Por conseguinte, difícil assegurar a nocividade dos paraísos fiscais apenas por beneficiarem a renda forânea mais do que os países de alta carga fiscal. ${ }^{51}$

\footnotetext{
${ }^{48}$ Cf. P. Baker, The concept of tax haven: a legal analysis, London, 2002, p. 10.

${ }^{49} \mathrm{Cf}$. P. Baker, The concept of tax haven: a legal analysis, p. 11.

50 OCDE. Harmful tax competition: an emerging global issue, 1998. pp. 13-14. V. também Baker, The concept of tax haven: a legal analysis, p.12.

${ }^{51}$ ALMEIDA, Aloísio Flávio Ferreira de. Tax havens: an analysis of the OECD work with policy recommendations,pp.10-11. Disponível em: http://www.receita.fazenda.gov.br/Publico/estudotributarios/TrabAcademicos/Resumos/AloisioTaxHavensab stract.pdf. Acesso em: 10 nov 2011
} 
Já sob o aspecto jurisdicional, Baker recorre ao direito internacional público para fundamentar que podem os paraísos fiscais legislar livremente sobre tributos, tanto em respeito ao princípio da não-intervenção dos Estados - permite aplicar a política que julgar mais conveniente em respeito à própria soberania-, como à liberalização do comércio tão apregoada pela Organização Mundial do Comércio-OMC. ${ }^{52}$

A própria OCDE, no decurso de seus trabalhos sobre concorrência fiscal nociva, alterou seu entendimento inicial, expresso no Relatório 1998, para reconhecer a soberania tributária de cada Estado, ciente de que níveis distintos de tributação poderão ser encontrados em diferentes sistemas tributários. Daí que a modernização promovida por um Estado em sua infra-estrutura fiscal, reduzindo suas alíquotas e ampliando sua base, em busca de maior neutralidade, é questão meramente de política doméstica, não justificando interferência. ${ }^{53}$

Taxando por impossível a tarefa de universalizar a definição de paraísos físcais, Baker sugere uma classificação quadripartida: (i) clássicos ou que não tributam a renda; (ii) que não tributam a renda de fontes estrangeiras; (iii) que dispõem de regimes fiscais privilegiados; e (iv) que se valem dos tratados - paraísos fiscais de tratados ou treaty tax havens. ${ }^{54}$

Por sua vez, Charles Irish sugere três diferentes categorias de paraísos fiscais, de acordo com a estrutura de seus sistemas fiscais: ${ }^{55}$

(i) paraísos fiscais puros: não instituem tributação direta sobre a renda, nem sobre sucessões, heranças e doações. Poderão, contudo, cobrar tributos aduaneiros, além de outros sobre o trabalho e o patrimônio imobiliário. Em geral, os custos dos investidores concentram-se na obtenção de licenças e registros em diversas atividades empreendidas na jurisdição, até mesmo para autorização de trabalho de estrangeiros. São muito utilizados como centros financeiros offshore para intermediar empréstimos obtidos junto a nãoresidentes que, por sua vez, são concedidos a outros não-residentes por meio de bancos ou instituições financeiras, livre de controles cambiais; ${ }^{56}$

\footnotetext{
${ }^{52}$ Cf. P. Baker, The concept of tax haven: a legal analysis, p.4.

${ }^{53}$ OCDE, 1998 Report. p. 15.

${ }^{54}$ Cf. P. Baker, The concept of tax haven: a legal analysis, pp. 6-8. Hermes Marcelo Huck observa que o conceito de paraíso fiscal variará conforme a fonte da qual emana. Logo, poderá assumir a condição de face negra do capitalismo, algoz das economias dos demais países, alternativa de fuga à opressão dos impostos que impedem o livre fluxo de capitais, ou, ainda, poderoso catalisador da economia capitalista mundial. V. HUCK, Hermes Marcelo. Evasão e elisão:rotas nacionais e internacionais do planejamento tributário. São Paulo:Saraiva, 1997, pp. 257-258.

${ }^{55}$ Cf. C. R. IRISH, Tax havens. In: Vanderbilt journal of transnational law, v. 15, $n^{o} 3.1982$.

${ }^{56}$ Como exemplos de paraísos puros, Charles Irish destacou Bahamas, Bermuda, Ilhas Cayman, Nauru, Vanuatu e Turks and Caicos.
} 
(ii) paraísos fiscais liberais: costumam tributar diretamente a renda, embora promovam algum alívio fiscal. Certo é que vários países de elevada tributação também prevêem tratamento favorecido em algumas circunstâncias. O que os distingue é o conjunto formado pelos incentivos fiscais, o volume de transações internacionais em comparação com a economia local e a postura do governo no estímulo às atividades internacionais que se beneficiem do tratamento tributário mais favorável; ${ }^{57}$

(iii) paraísos fiscais de tratados (treaty tax havens): signatários de um acordo de bitributação que dele se valem para ofertar benefícios a pessoas que não mantenham residência em nenhum dos signatários. É modalidade de ampla utilização por permitir o uso de canais (conduits) em transações de investimento internacional. Decorrem de uma combinação de fatores que exigem um acordo de bitributação capaz de aliviar a retenção na fonte sobre juros, dividendos e royalties pagos aos residentes do paraíso fiscal de tratado; baixa ou nenhuma imposição tributária sobre a renda coberta pelo acordo no paraíso fiscal; e não tributação das remessas de juros, dividendos e royalties saídas do paraíso fiscal de tratado. ${ }^{58}$

Como se vê, é relevante a questão da definição dos paraísos fiscais, especialmente porque o viés com que cada Estado busca identificá-los depende da percepção dos riscos de erosão de suas bases tributárias, em decorrência da atração exercida no exterior por regimes de tributação mais favoráveis. ${ }^{59}$

Na visão de Arnold e Dibout, os paraísos fiscais podem ser classificados, pela legislação nacional, segundo critérios não-fiscais e critérios fiscais. Países que adotam os primeiros valem-se de parâmetros outros que não ligados ao ônus tributário, como, por exemplo, sigilo bancário ou negativa de troca de informações. Por seu giro, os que adotam critérios fiscais entendem haver tributação mínima ou nenhuma na jurisdição estrangeira sob análise. ${ }^{60}$

Ante a escolha de critérios fiscais, haverá dificuldade em definir qual alíquota mínima segrega a tributação adequada da abusiva. Não apenas pelo fato de a tributação mínima seguir miríade de critérios afetos a políticas públicas, mas também porque referência a alíquotas sempre trará problemas se as bases diferirem. Para o Brasil, sistemas

\footnotetext{
${ }^{57}$ Seriam exemplos de paraísos liberais: Irlanda, Hong Kong, Panamá, Costa Rica.

${ }^{58}$ Cf. H. M. Huck, Evasão e elisão:rotas nacionais e internacionais do planejamento tributário, p. 268.

${ }^{59} \mathrm{Cf}$. B. Arnold e P. Dibout, Limits on the use of low-tax regimes by multinational businesses: current measures and emerging trends general reports. In: Cahiers de droit fiscal international, vol. LXXXVI b. Hague: International Fiscal Association, 2001. p. 28.

${ }^{60} \mathrm{Cf}$. B. Arnold e P. Dibout, Limits on the use of low-tax regimes by multinational businesses: current measures and emerging trends general reports, p.31
} 
tributários cuja alíquota máxima sobre a renda não atinja $20 \%$ serão considerados paraísos fiscais. ${ }^{61}$ Há legislações mais tolerantes, como a húngara, em que o limite está em $10 \% .{ }^{62}$

As classificações não param por aqui. Se se consultar em diversos autores, certamente outras formas de segregar e agrupar paraísos fiscais serão propostas seguindo critérios como, inter alia, tributos que desoneram, contribuintes que mais beneficiam, localização geográfica e sigilo da informação. Todavia, o que se está a expor é a dificuldade para identificação de um paraíso fiscal. Multifacetado, ele pode se confundir com uma pequena ilha cuja economia gire bilhões de dólares, um país emergente em pleno desenvolvimento ou mesmo um país exportador de capital já desenvolvido.

Sob esta idéia, Charles Irish indica os E.U.A. como críticos contumazes dos paraísos fiscais, mas que não estariam livres de serem classificados como um deles, especialmente sob o critério da renda de investimentos em imóveis. ${ }^{63}$

Com a publicação de seu Relatório 1998, a OCDE iniciou seus trabalhos de combate aos efeitos perniciosos dos paraísos fiscais. Em sua visão, haveria dois grandes males, sobre os quais pesava a presunção de não cooperação, paraísos fiscais e jurisdições dotadas de regimes fiscais privilegiados. Ambos apresentavam potencial para causar danos sobre a renda individual ou de empresas, dentre os quais: ${ }^{64}$

(i) erosão da base de tributação de outros países, pela distorção dos fluxos de investimento, afetando justiça e equilíbrio dos sistemas tributários;

(ii) desestímulo dos contribuintes ao cumprimento das obrigações tributárias;

(iii) quebra da correlação entre ingresso tributário e gasto público - free riders;

(iv) modificação na composição da arrecadação, trocando a base "renda" por fatores de menor mobilidade, tais como trabalho, consumo e propriedade; e

(v) elevação dos custos administrativos para fisco e contribuintes.

Entre o potencial para causar danos e efetivamente causá-los, há uma distância a ser vencida pela difícil tarefa de definir, afinal, a quem deveria ser atribuído o status de paraíso ou regime não cooperante. A OCDE desincumbiu-se desse mister sem propor uma

${ }^{61}$ Cf.. BRASIL, Lei 9.430/96, art. 24 .

${ }^{62} \mathrm{Cf}$. B. Arnold e P.Dibout, Limits on the use of low-tax regimes by multinational businesses: current measures and emerging trends general reports, p..31

${ }^{63}$ Cf. C. R. Irish, Tax havens, pp. 451-452. Mesmo sob outros critérios que nada digam com a renda, como o sigilo mantido por autoridades públicas e bancos no chamado ask-no-questions-approach, pelo qual não se divulga dados sobre acionistas de empresas pelo simples fato de que não são sequer perguntados quando da abertura das mesmas. Este o caso do estado norte-americano de Nevada. Wyoming e Delaware também podem conjugar situações específicas de anonimato e não tributação Cf. The Economist. The G20 and tax Haven hypocrisy. 28/03/2009.

${ }^{64}$ Cf. OCDE, Relatório 1998, p. 16. 
definição nítida, de contornos bem demarcados. Ao invés, estipulou um critério múltiplo para identificar os aspectos nocivos de específicas jurisdições ou regimes. ${ }^{65}$

A ratio utilizada pela OCDE para sua argumentação e definição de nocividade era a de que residentes dos países de tributação "normal" poderiam desviar investimentos, tornando-se free riders de bens e serviços públicos de seus países de residência. Ademais, os Estados seriam tentados a alterar a estrutura da tributação para bases menos móveis a fim de compensar as perdas com a arrecadação, causadas, básica e precipuamente, pelos desvios da renda para regimes e jurisdições que concedessem tratamento privilegiado. $\mathrm{O}$ resultado seria redução da progressividade dos sistemas de tributação "normal" ${ }^{6}$

O critério múltiplo adotado passava por tributação zero ou nominal para paraísos fiscais e alíquotas efetivas zero ou baixas sobre a renda relevante no caso de regimes fiscais privilegiados; ausência de efetiva troca de informações e de transparência, além do teste de atividades substanciais para paraísos fiscais ou de ring-fencing para regimes privilegiados. ${ }^{67}$

Tendo decidido priorizar o critério de zero ou nominal tributação, a OCDE sustentou que este já seria condição necessária para identificar paraísos fiscais e que, ao ser combinada com autopromoção como local destinado à fuga da tributação, poderia ser

\footnotetext{
${ }^{65}$ Cf. OCDE, Relatório 1998, p.4.

${ }^{66}$ Cf. A. F.F. Almeida, Tax havens: an analysis of the OECD work with policy recommendations, pp.7-9.

${ }^{67} \mathrm{Na}$ visão primeva da OCDE, os paraísos fiscais proporcionavam redução de tributos e confidencialidade a investidores individuais e multinacionais, devendo ser identificados de acordo com os seguintes quatro fatores: (i) tributação inexistente ou meramente nominal: condição necessária para qualificar um tax haven; (ii) ausência de uma eficaz troca de informações: adoção de regras de proteção e de sigilo contra ações empreendidas por autoridades fiscais; (iii) falta de transparência: ausência de previsão sobre transparência na legislação, o que estimula a esconder a origem de rendas ou a mantê-las indeclaradas no Estado de residência. (iv) inexistência de atividade substancial: este é um fator sugestivo sobre o propósito do paraíso fiscal em atrair apenas investimentos ou transações estimuladas pelo fator tributário. Talvez esse fator possa esclarecer como ilhotas recebem, em IED, bilhões de dólares mesmo que aparentem não possuir a correspondente capacidade de produção. Por sua vez, a identificação de um regime fiscal privilegiado nocivo, em países membros e não-membros, dependeria de outros quatro fatores, a saber: (i) o regime impõe baixa ou nenhuma tributação sobre renda relevante: ponto inicial para configuração de um regime como nocivo, contudo é necessário que haja interação com um ou mais dos critérios a seguir; (ii) a operação do regime é não-transparente: a falta de transparência é conceito largo que inclui, dentre outros, regras tributárias negociáveis, aplicação favorável de leis e regulamentos e falha em disponibilizar mais amplamente as práticas administrativas; (iii) a jurisdição que opera o regime não troca informações com outros países de forma eficaz: este é um forte indício que haja práticas concorrenciais nocivas; (iv) o regime é ring-fenced: alguns regimes de tributação favorável são parcial ou totalmente isolados dos mercados domésticos do país que concede o regime. O país sente a necessidade de proteger sua própria economia do regime por meio de ring-fencing. ${ }^{67}$ Isto é um indicativo forte de que o regime tem potencial para criar efeitos nocivos excedentes. O ring-fencing pode adotar várias formas, dentre as quais a exclusão de contribuintes residentes de tirar vantagens do regime preferencial ou empresas que se beneficiem do regime podem ser implícita ou expressamente vedadas de operar no mercado doméstico V. A.F.F.Almeida, Tax havens: an analysis of the OECD work with policy recommendations, p.7.
} 
suficiente para identificá-los. Esta era uma conclusão já controvertida em sua divulgação e que se mostrou precipitada, como veremos a seguir. ${ }^{68}$

Em suma, o teor do Relatório 1998 marcou a idéia de que uma jurisdição com tributação zero ou apenas nominal seria um paraíso fiscal. Este último, por seu giro, seria não cooperante e nocivo, salvo se provado o contrário. ${ }^{69}$

A partir de 2000, a OCDE passou a emitir Relatórios Progressivos, sendo que em 2001, alterou seu entendimento, substancialmente, ao reconhecer que o critério da tributação zero ou apenas nominal não seria suficiente, por si só, para caracterizar um paraíso fiscal. Desde então, a ausência de tributação passaria a ser utilizada como um portal para situações que justificassem estender a análise aos outros critérios. ${ }^{70}$

A outra significativa alteração nos critérios definidores de paraísos e regimes preferenciais foi o desprezo pelo critério das atividades substanciais. Já se manifestara a OCDE no sentido de que atestar a substancialidade de atividades seria rugoso mister, ${ }^{71}$ concluindo, em 2001, que este critério não deveria ser utilizado para determinar se uma jurisdição seria ou não cooperante.

Restaram, portanto, dois critérios para definir jurisdições cooperantes que adquiriram cada vez maior peso no combate às práticas tributárias nocivas: troca de informações e transparência.

Uma jurisdição transparente deverá manter o ordenamento tributário livre de quaisquer traços de opacidade, coibindo regras que excepcionem as normas previstas e práticas autorizadas por lei, além de dispor sobre conformação das regras contábeis aos padrões geralmente aceitos, prevendo sobre auditoria e registro de contas. Adicionalmente, autoridades públicas de uma jurisdição transparente deverão ter acesso a informações sobre propriedade (beneficiário efetivo) de quaisquer entidades e a informações bancárias relevantes para questões civis e criminais. ${ }^{72}$

Já uma jurisdição comprometida em efetiva troca de informações deve prever, em sua legislação, o acesso da informação fiscal a autoridades estrangeiras, em situações de relevância e após solicitação para análises fiscais no caso concreto, resguardados o sigilo

${ }_{68}^{68}$ Cf. P. Baker, The concept of tax haven: a legal analysis, p. 32 .

${ }^{69}$ Cf. P. Baker, The concept of tax haven: a legal analysis, p. 32 .

${ }^{70}$ Essa mudança de entendimento significou respeito a princípios típicos de direito internacional público, tais como o da igualdade formal entre os Estados e o da não-intervenção. Foi naquela ocasião que a OCDE registrou, de fato, seu reconhecimento sobre o direito de qualquer jurisdição determinar sua política tributária, escolhendo alíquotas e tributos que julgar convenientes. Cf. OCDE. The OECD's Project on Harmful Tax Practices: The 2001 Progress Report. p.7.

${ }^{71}$ OCDE. Relatório 1998, Item 55.

${ }^{72}$ Cf. OCDE, The OECD's Project on Harmful Tax Practices: The 2001 Progress Report, parágrafo 37. Disponível em: www.oecd.org. Acesso em 15 nov 2011. 
da informação fiscal. Ademais, deverá implantar práticas administrativas para que as normas sobre troca de informações funcionem corretamente e sejam passíveis de monitoramento. $^{73}$

Inobstante louvar os esforços da OCDE por representarem um ponto de inflexão no direito tributário internacional, consubstanciando-se na primeira iniciativa de uma organização influente em formular princípios gerais para a coexistência de Estados com sistemas tributários distintos, Baker entende que o Relatório 1998 falhou em três situações inter-relacionadas: ${ }^{74}$

(i) limitou artificialmente o conceito de paraíso fiscal, considerando apenas os paraísos clássicos (tributação zero) e comprometidos apenas com atividades móveis, especialmente financeiras e de serviços;

(ii) presumiu que os paraísos fiscais seriam nocivos para os outros países, esquecendo-se de justificações políticas de cada caso; e

(iii) não definiu critérios adequados para identificar os paraísos fiscais transgressores, pois que ignorou a soberania tributária de cada país.

Sob este prisma, prossegue Baker, a OCDE tratou de forma mais suave os regimes fiscais privilegiados hospedados em jurisdições de tributação "normal", em detrimento daqueles adotados por pequenas jurisdições, cuja aparência seria indicativa de nocividade em suas práticas.

Avi-Yonah, por outro lado, defende os trabalhos da OCDE em todas as suas fases, pois que sem eles muitos cidadãos e empresas sentir-se-iam mais à vontade para desviar seus investimentos para paraísos fiscais. Estes, por seu turno, teriam exercido ainda maior influência nas transferências do capital internacional, cada vem mais móvel. ${ }^{75}$

Na continuidade de seus trabalhos, a OCDE, a exemplo do que fizera já nos Relatórios 1998, 2000 e 2001, buscou interação entre membros e não-membros, visando à cooperação para resolver a concorrência fiscal nociva. Valorizando transparência e troca de informações, divulgou, em 2002, seu Modelo de acordo para troca de informações fiscais (TIEAS), conquistando a adesão de outras organizações internacionais. A partir de

\footnotetext{
${ }^{73}$ Cf. OCDE, The OECD's Project on Harmful Tax Practices: The 2001 Progress Report, parágrafo 38. Disponível em: www.oecd.org. Acesso em 15 nov 2011

${ }^{74}$ Cf. P. Baker, The concept of tax haven: a legal analysis, p. 35.

75 Avi-Yonah pontua que 103 países, desde 1998, adotaram tratamento fiscal preferencial em busca de investimentos. V. AVI-YONAH, Reuven S. Avi-Yonah, Reuven S. The OECD harmful tax competition report: a tenth anniversary retrospective. University of Michigan Law School, Working Paper No. 115, 2008. Disponivel em: http://ssrn.com/abstract=1194942. Acesso em: 05 set 2011.
} 
2004, a OCDE toma como meta a questão do nivelamento do campo de jogo, expressão usada para evitar discriminações de toda a sorte entre as diversas jurisdições envolvidas com a cooperação internacional.

Sob o enfoque do nivelamento do campo de jogo, a OCDE age de forma diferente do seu primeiro viés (1998), em que tributação zero ou nominal era indicativo de transgressão, tanto que, a partir de 2006, emite relatório cujo nome demonstra seu principal objetivo: Cooperação Fiscal - no rumo do campo de jogo nivelado. ${ }^{76}$ Este relatório tem sido atualizado anualmente, concentrando-se na atuação legislativa e administrativa dos países quanto à transparência e troca de informações.

A inclusão do art. 26 (troca de informações) no Modelo de acordo de bitributação, o esvaziamento da lista negra ${ }^{77}$ e a ampla celebração de TIEAS desde a divulgação de seu modelo em $2002^{78}$ são sinais de que a mudança de paradigma da OCDE rendeu frutos que se podem resumir no cometimento de diversas jurisdições em efetivamente nivelar $o$ campo de jogo.

A legislação brasileira não adota a expressão paraísos fiscais, mas países com tributação favorecida e regimes fiscais privilegiados, assim entendidos os que não tributam a renda ou o fazem a alíquota máxima inferior a $20 \%$ e também os que privilegiam o sigilo da informação, negando acesso à composição societária de pessoas jurídicas, à sua titularidade ou à identificação do beneficiário efetivo de rendimentos atribuídos a não-residentes. ${ }^{79}$

As operações realizadas por residentes no Brasil com pessoas físicas ou jurídicas residentes em paraísos fiscais, ainda que não vinculadas, terão por conseqüência o aumento da retenção na fonte para $25 \%$ e a aplicação das regras de preços de transferência, assim como a redução da dedutibilidade dos juros pelas regras de subcapitalização, de 2:1 para 0,3:1 na relação debt/equity. ${ }^{80}$

\section{II.1.4.3 Lista de paraísos fiscais}

\footnotetext{
${ }^{76}$ OECD. Tax Co-operation: Towards a Level Playing Field - 2006 Assessment by the Global Forum on Taxation (2006). Disponível em: www.oecd.org. Acesso em 15 nov 2011.

${ }^{77}$ OECD. A Progress Report on the Jurisdictions Surveyed by the OECD Global Forum in Implementing The Internationally Agreed Tax Standard, 2011. Disponível em: www.oced.org. Acesso em 15 nov 2011.

${ }^{78} \mathrm{OECD}$. Tax Information Exchange Agreements (TIEAS). Disponível em: http://www.oecd.org/document/7/0,3746,en_2649_33745_38312839_1_1_1_1,00.html. Acesso 15 nov 2011.

${ }^{79}$ BRASIL, Lei 9.430/96, arts. 24 e 24-A.

${ }^{80}$ A retenção na fonte dos rendimentos remetidos a não-residentes é, usualmente, tributada a $15 \%$. As regras de subcapitalização permitem a dedutibilidade de juros até o dobro do investimento no patrimônio líquido da empresa brasileira. V. tópicos IV.3.3 e IV.3.4.
} 
A legislação doméstica pode divulgar listas de paraísos fiscais. Como não havia uniformidade na emissão dessas listas, até porque obedeciam a critérios internos, típicos de cada ordem nacional, distorções surgiram na medida em que o tratamento dispensado a regimes hospedados em países desenvolvidos foram, inicialmente, pouco lembrados.

As listas servem para elencar os paraísos fiscais - negras ou black lists - ou indicar os países que não se sujeitam a medidas anti-elisão ou anti-evasão - brancas ou white lists. Em meio a elas, as listas cinza (grey lists) permitem o monitoramento das jurisdições intermediárias.

No que toca à taxatividade dessas listas, não se encontra posição singular. No caso brasileiro, a última lista foi divulgada em 2010, pela IN/RFB 1.037, trazendo um rol taxativo de paraísos fiscais. ${ }^{81}$ A lista brasileira é vinculante para as autoridades fazendárias e contribuintes, de modo que operações efetuadas com domiciliados em alguma das jurisdições listadas acarretará, de plano, a mudança para o regime de tributação da renda

${ }^{81}$ BRASIL. RFB. IN 1037/10, DOU de 7 de junho de 2010. Art. $1^{\circ}$ Para efeitos do disposto nesta Instrução Normativa, consideram-se países ou dependências que não tributam a renda ou que a tributam à alíquota inferior a $20 \%$ (vinte por cento) ou, ainda, cuja legislação interna não permita acesso a informações relativas à composição societária de pessoas jurídicas ou à sua titularidade, as seguintes jurisdições:

I - Andorra; II - Anguilla; III - Antígua e Barbuda; IV - Antilhas Holandesas; V - Aruba; VI - Ilhas Ascensão; VII Comunidade das Bahamas; VIII - Bahrein; IX - Barbados; X - Belize; XI - Ilhas Bermudas; XII Brunei; XIII - Campione D'Italia; XIV - Ilhas do Canal (Alderney, Guernsey, Jersey e Sark); XV - Ilhas Cayman; XVI - Chipre; XVII - Cingapura; XVIII - Ilhas Cook; XIX - República da Costa Rica; XX Djibouti; XXI - Dominica; XXII - Emirados Árabes Unidos; XXIII - Gibraltar; XXIV - Granada; XXV Hong Kong; XXVI - Kiribati; XXVII - Lebuan; XXVIII - Líbano; XXIX - Libéria; XXX - Liechtenstein; XXXI - Macau; XXXII - Ilha da Madeira; XXXIII - Maldivas; XXXIV - Ilha de Man; XXXV - Ilhas Marshall; XXXVI - Ilhas Maurício; XXXVII - Mônaco; XXXVIII - Ilhas Montserrat; XXXIX - Nauru; XL Ilha Niue; XLI - Ilha Norfolk; XLII - Panamá; XLIII - Ilha pitcairn; XLIV - Polinésia Francesa; XLV - Ilha Queshm; XLVI - Samoa Americana; XLVII - Samoa Ocidental; XLVIII - San Marino; XLIX - Ilhas de Santa Helena; L - Santa Lúcia; LI - Federação de São Cristóvão e Nevis; LII - Ilha de São Pedro e Miguelão; LIII São Vicente e Granadinas; LIV - Seychelles; LV - Ilhas Solomon; LVI St. Kitts e Nevis; LVII Suazilândia; LVIII - Suíça; (Vide Ato Declaratório Executivo RFB no 11/2010) LIX - Sultanato de Omã; LX - Tonga; LXI - Tristão da Cunha; LXII - Ilhas Turks e Caicos; LXIII - Vanuatu; LXIV - Ilhas Virgens Americanas; LXV - Ilhas Virgens Britânicas. Art. ${ }^{\circ}$ São regimes fiscais privilegiados:

I - com referência à legislação de Luxemburgo, o regime aplicável às pessoas jurídicas constituídas sob a forma de holding company; II - com referência à legislação do Uruguai, o regime aplicável às pessoas jurídicas constituídas sob a forma de "Sociedades Financeiras de Inversão (Safis)" até 31 de dezembro de 2010; III - com referência à legislação da Dinamarca, o regime aplicável às pessoas jurídicas constituídas sob a forma de holding company que não exerçam atividade econômica substantiva; (IN/RFB nº 1.045/2010); IV - com referência à legislação do Reino dos Países Baixos, o regime aplicável às pessoas jurídicas constituídas sob a forma de holding company que não exerçam atividade econômica substantiva; (IN/RFB $\mathrm{n}^{\circ}$ 1.045/2010); V - com referência à legislação da Islândia, o regime aplicável às pessoas jurídicas constituídas sob a forma de International Trading Company (ITC); VI - com referência à legislação da Hungria, o regime aplicável às pessoas jurídicas constituídas sob a forma de offshore KFT; VII - com referência à legislação dos Estados Unidos da América, o regime aplicável às pessoas jurídicas constituídas sob a forma de Limited Liability Company (LLC) estaduais, cuja participação seja composta de não residentes, não sujeitas ao imposto de renda federal; ou VIII - com referência à legislação da Espanha, o regime aplicável às pessoas jurídicas constituídas sob a forma de Entidad de Tenencia de Valores Extranjeros (E.T.V.Es.); IX - com referência à legislação de Malta, o regime aplicável às pessoas jurídicas constituídas sob a forma de International Trading Company (ITC) e de International Holding Company (IHC). 
aplicável a paraísos fiscais, como, por exemplo, elevação da alíquota de retenção na fonte de $15 \%$ para $25 \%$ e aplicação das normas de preços de transferência. Legislam da mesma forma Austrália, Portugal e Nova Zelândia.

Em contrapartida, Alemanha e França divulgam suas listas de paraísos fiscais sem força vinculante entre fisco e contribuinte, pois que meramente indicativas. A principal crítica a este último modelo é no sentido da possível arbitrariedade que poderá resultar da ação fiscal baseada em listas exemplificativas.

Curiosidade decorrente das diversas listas unilateralmente emitidas é o fato de que uma dada jurisdição poderia se enquadrar na lista negra de um país, e na cinza ou mesmo branca de outro, a depender dos critérios escolhidos pelo país emitente.

Fato é que o monitoramento constante dessas listas exige um enorme esforço do país emitente. A atualização periódica das listas requer acompanhamento minucioso de sistemas tributários diversos e suas práticas, o que eleva custos administrativos e desafia a exeqüibilidade da tarefa. ${ }^{82}$

II.1.5 Mitigação da concorrência tributária internacional: cooperação

Como visto, a cooperação internacional tornou-se objetivo prioritário na condução dos trabalhos de combate à concorrência desleal. Isto se deveu, em grande parte, aos efeitos da globalização, que oferece diversos meios de potencialização das práticas nocivas, tornando inócua a ação isolada de um Estado.

Atenta ao fato, a OCDE procurou estimular a cooperação internacional, apresentando diretrizes contrárias a regimes preferenciais eventualmente praticados por seus membros. ${ }^{83} \mathrm{O}$ propósito, claramente, era adotar conduta exemplar interna corporis antes de solicitar cooperação a países não-membros. ${ }^{84}$

\footnotetext{
${ }^{82}$ Cf. P. Baker, The concept of tax haven: a legal analysis, p. 28.

${ }^{83}$ Cf. OCDE, Relatório 1998, Recomendação 15.

${ }^{84}$ Assim, os membros teriam um prazo máximo de 5 anos, contados da aprovação das diretrizes pelo Conselho da OCDE, para removerem práticas nocivas de seus regimes fiscais preferenciais, de acordo com os critérios já especificados pelo Relatório 1998. Sumariando o tema, as recomendações da OCDE dirigiram-se aos princípios de boa administração e a eventuais vínculos entre países membros e paraísos fiscais. Neste último caso, esperava-se de países que hospedassem dependências identificadas como paraísos fiscais, a convicção de que seus vínculos não resultariam em aumento ou promoção da concorrência fiscal nociva.
} 
Para a implantação de suas recomendações sobre cooperação, a OCDE sugeriu a criação do Forum sobre Concorrência Tributária Nociva. ${ }^{85}$ Este foro deveria produzir uma lista de paraísos fiscais identificados conforme os critérios já descritos pela OCDE. Assim, em 2000, foi divulgada uma lista com 35 jurisdições a que se pretendia taxar por paraísos fiscais não cooperantes, caso não firmassem compromisso escrito em trocar informações em assuntos de natureza tributária, nos âmbitos penal e civil internacionais. ${ }^{86}$

Em 2002, 28 daquelas 35 jurisdições haviam se comprometido expressamente em cooperar com a troca de informações, de modo que a primeira lista negra da OCDE foi divulgada com apenas 7 jurisdições: Andorra, Ilhas Marshall, Libéria, Liechtenstein, Mônaco, Nauru e Vanuatu. Em 2008, restavam apenas 3: Liechtenstein, Mônaco e Andorra. ${ }^{87}$ Atualmente, a lista de jurisdições não-cooperantes está vazia. ${ }^{88}$

Com a fixação dos padrões internacionalmente aceitos em matéria tributária, as listas da OCDE passaram a subdividir-se em três grupos: (i) o das jurisdições que não se comprometeram com os padrões fiscais internacionalmente aceitos (lista negra); (ii) o das jurisdições que se comprometeram a implementar tais padrões, mas ainda não o fizeram substancialmente (lista cinza); e (iii) o das jurisdições que substancialmente implementaram os padrões sob comento (lista branca).

Implementar substancialmente o padrão fiscal acordado internacionalmente, exige assinatura de acordos ou adoção de medidas unilaterais que permitam trocar informações, segundo os padrões previstos, com no mínimo 12 outros países. ${ }^{89}$ O Brasil, assinou 34 acordos bilaterais em que se dispõe a trocar informações (33 acordos de bitributação e 1 acordo para troca de informações com os Estados Unidos) e ascendeu à classe dos países constantes da lista branca, em junho de $2010 .^{90}$

As recentes discussões acerca da cooperação internacional ultrapassaram o âmbito da OCDE, franqueando a participação mais ativa de um número crescente de países não-

\footnotetext{
${ }^{85}$ Assim nasceu, em 2000, o Global Forum on Transparency and Exchange of Information for Tax Purposes, cujos trabalhos são desenvolvidos de forma multilateral por membros e não-membros da OCDE, com vistas a desenvolver um padrão tributário acordado internacionalmente. O Brasil é um de seus membros.

${ }^{86}$ Cf. R. Avi-Yonah, The OECD Harmful Tax Competition Report: A Tenth Anniversary Retrospective (August 1, 2008), p.3.

87 Cf. R. Avi-Yonah, The OECD Harmful Tax Competition Report: A Tenth Anniversary Retrospective (August 1, 2008), pp.4-5.

${ }^{88}$ OECD. A Progress Report on the Jurisdictions Surveyed by the OECD Global Forum in Implementing The Internationally Agreed Tax Standard, 2011. Disponível em: www.oced.org. Acesso em 15 nov 2011.

${ }^{89}$ Assim foi definido pelo Subgrupo encarregado dos temas de Nivelamento do Campo de Jogo em outubro de 2008.

90 OECD. Exchange of Tax Information Portal. Disponível em: http://www.eoi-tax.org/jurisdictions/BR\#agreements. Acesso em 15 nov 2011. Deve-se ressaltar que o Brasil tem 33 acordos de bitributação assinados, mas 4 ainda não estão em vigor: Rússia, Trinidad e Tobago, Turquia e Venezuela. V. III.2.3.7.
} 
membros. Outros organismos têm trabalhado por um padrão tributário acordado internacionalmente, como o G-8, ${ }^{91} \mathrm{G}-20,{ }^{92}$ e ONU.

\section{II.1.5.1 Troca de informações em matéria fiscal}

Aos 18 de abril de 2002, a OCDE divulgou seu Modelo de Acordo sobre Troca de Informações em Matéria Tributária, cujo maior objetivo seria promover a cooperação internacional por meio da troca de informações fiscais. Para tanto, pretendia fixar padrões que caracterizassem efetiva troca de informações, o que somente ocorreu em 2006, com a fixação dos padrões sobre confiabilidade e disponibilidade de registros contábeis, fruto dos trabalhos desenvolvidos pelo Grupo Conjunto Ad Hoc sobre Contas. ${ }^{93}$

O Modelo foi desenvolvido pelo Grupo de Trabalho sobre Efetiva Troca de Informações, composto por membros e não-membros da $\mathrm{OCDE},{ }^{94}$ na esteira dos trabalhos iniciados com o Relatório 1998, possuindo duas versões: multilateral e bilateral. A multilateral não é vinculante como num acordo multilateral tradicional, apenas propondo a base para um conjunto de acordos bilaterais, vinculando cada parte contratante com aquelas que, especificamente, indicar em seu instrumento de ratificação. A versão bilateral pretende servir de modelo para acordos de troca bilateral de informações.

91 O G-8 é formado pelas oito economias mais industrializadas do planeta: EUA, Canadá, Japão, França, Alemanha, Itália, Reino Unido e Rússia. Em sua agenda encontram-se temas relevantes para a economia mundial, como liberalização do comércio internacional, segurança alimentar, mudanças climáticas e o incentivo ao crescimento econômico equilibrado. Detalhes em: www.canadainternational.gc.ca/g82010. Acesso em 20 nov 2011.

92 O G-20 é um grupo formado por 19 países e mais a União Européia, dentre os quais o Brasil, representando as vinte principais economias do globo. O G-20 funciona como um foro de discussões entre países industrializados e emergentes sobre temas cruciais para a estabilidade da economia mundial. Dentre seus principais campos de atuação estão contribuir para o fortalecimento da arquitetura financeira internacional e fornecer oportunidades para diálogo sobre políticas nacionais, cooperação internacional e instituições financeiras internacionais. Para maiores detalhes: www.g20.org. Acesso em 20 nov 2011.

93 Foram, então fixados os seguintes padrões fundamentais sobre transparência e troca de informações em matéria fiscal, a serem integralmente implementados por todos os países:

(i) existência de mecanismos para troca de informações mediante solicitação;

(ii) troca de informações de interesse do direito tributário doméstico em matéria civil e penal;

(iii) ausência de restrições à troca de informações por motivo de aplicação do princípio da dupla incriminação ou questões afetas à tributação doméstica;

(iv) respeito às salvaguardas e limitações;

(v) previsão de regras de estrita confidencialidade para as informações trocadas;

(vi) disponibilidade de informações confiáveis (em particular sobre operações bancárias, propriedade, identidade e informações contábeis) e poderes para obter e fornecer tais informações em resposta a uma solicitação específica. V. OCDE. Tax Co-operation 2009 - Towards a level playing field. Disponível em: http://www.oecd.org. Acesso em 07 nov 2011.

94 O Grupo de Trabalho, além dos países membros da OCDE, foi composto por representante de Aruba, Bermuda, Bahrein, Ilhas Cayman, Ilha de Man, Ilhas Maurício, Chipre, Malta, Antilhas Holandesas, Seychelles e San Marino. 
O Modelo conquistou amplo suporte em outros foros como ONU, UUEE, G-8 e G-20. Já em 2004, por exemplo, este último incluiu em sua agenda o apoio à OCDE especialmente em matéria de cooperação internacional. Em sua Declaration on Strengthening the Financial System, de 2 de abril de 2009, o G-20 chega a sugerir contramedidas às jurisdições listadas pela OCDE como contrárias aos padrões internacionais de troca de informações. ${ }^{95}$

Os Acordos para troca de informações, em qualquer de suas versões, representam uma das várias formas de implementação dos padrões internacionais sobre o tema. Outros instrumentos, incluindo os acordos de bitributação, podem também ser utilizados com esse mesmo objetivo.

\section{II.1.6 Sistemas Tributários Competitivos}

Em termos de fluxo de IED, o Brasil tornou-se o $5^{\circ}$ destino mais atrativo do mundo, segundo os dados divulgados pela UNCTAD em seu World Investment Report $2011 .{ }^{96} \mathrm{O}$ País subiu dez posições em apenas um ano, colaborando para que o fluxo de IED aos países em desenvolvimento (inflow) superasse, pela primeira vez, o volume destinado a países desenvolvidos. Ante este resultado alvissareiro, cumpre indagar o que teria feito as MNEs aumentarem seus investimentos em PED. A UNCTAD aponta para rápida recuperação da economia no contexto da crise de 2008, demanda interna aquecida, e crescimento do fluxo sul-sul, todos fatores econômicos que poderiam ser resumidos em apenas um único objetivo das MNEs: manterem-se competitivas no cenário da produção mundial. ${ }^{97}$

Se o investidor estrangeiro pretende se manter competitivo no cenário internacional, correndo riscos no exterior em vez de investir em sua própria residência, é por encontrar ambiente propício a tais realizações. Seria uma análise do fluxo de IED em sentido inverso (outflow). Sob este ângulo, embora ocupe posição destacada no âmbito da América Latina, ${ }^{98}$ o Brasil não lista entre os 20 principais exportadores de investimento,

${ }^{95}$ G20. Declaration on Strengthening the Financial System. Disponível em: www.g20.org. Acesso em 01 dez 2011.

${ }^{96}$ UNCTAD, World Investment Report 2011, p.3. Disponível em: http://www.unctad.org/Templates/webflyer.asp?docid=15189\&intItemID=2068\&lang=1\&mode=downloads. Acesso em 10 out 2011.

${ }^{97}$ Cf. UNCTAD, World Investment Report 2011, p.3.

${ }^{98}$ Conjuntamente com Chile, Colômbia e México. Cf. UNCTAD, World Investment Report 2011 , p.7. 
diferente do que ocorre com os outros BRICs, já que China, ( $5^{a}$ posição), Rússia ( $\left.8^{a}\right)$ e Índia $\left(20^{\mathrm{a}}\right)$ desenvolvem política de investimento de forma ambivalente. ${ }^{99}$

Naturalmente que uma análise completa acerca dos fatores que podem ter conduzido o Brasil a esse bom resultado deve considerar variáveis que estão além do escopo deste trabalho. Entretanto, a tributação, enquanto um dos fatores de influência sobre a alocação do IED, pode ser útil instrumento de competitividade para o País, o que justifica a seqüência das análises.

A configuração de um sistema tributário competitivo requer medidas no campo da fiscalidade e da extrafiscalidade, além de outras referentes à atuação eficaz e harmônica de organismos ligados ao Executivo, Legislativo e Judiciário que, de alguma forma, participam da relação entre Estado e contribuinte, como agentes de fiscalização, cortes administrativas, legisladores e magistrados. A pós-modernidade exige transparência, agilidade e coerência nas respostas à sociedade internacional.

A seguir, passa-se a sintetizar algumas características relevantes para o aumento da competitividade no cenário internacional, com base na lição de Joachim Lang, ${ }^{100}$ sem que se afaste da teoria da internacionalização da produção, iniciada por Hymer. ${ }^{101}$

(i) Eficiência econômica da tributação: Sistemas tributários competitivos são eficientes do ponto de vista econômico, o que se verifica pela relação de benefício entre carga tributária e fatores de localização do investimento. Quanto mais fatores locacionais favoráveis, menos o Estado oferta incentivos fiscais; já a ausência dos primeiros leva a maior oferta dos últimos.

Um sistema tributário eficiente deve ofertar neutralidade de decisão econômica, evitando, ao máximo, o efeito alocativo. Assim, distorções da eficiência econômica seriam causadas por normas tributárias indutoras com suas onerações especiais e auxílios fiscais ou, ainda, por cedularização da renda que deveria ser gravada com base na universalidade.

Ocorre que não há - e parece não ser possível haver- tributo que não influencie o comportamento do agente econômico. Neste ponto, está-se diante de uma utopia. Ao legislador, ao invés de buscar atingir a neutralidade, melhor seria "ponderar os efeitos

\footnotetext{
99 A China vem promovendo uma notável expansão, adquirindo ativos no exterior em ampla faixa de segmentos e países, havendo superado, inclusive, os japoneses no total de saída de IED ao atingirem US\$ 68 bilhões de IED em 2010. Cf. UNCTAD, World Investment Report 2011, p.7

${ }^{100}$ Cf. J. Lang, A tributação das empresas no contexto da concorrência internacional, pp. 29-37.

${ }^{101}$ V. tópico II.1.1 supra.
} 
econômicos de suas medidas, utilizando-se das normas tributárias (...) para indução (...) visando às finalidades da própria intervenção econômica." ${ }^{, 102}$

Com base nesse raciocínio, o enfoque sobre a neutralidade recairá, prioritariamente, no escopo da livre concorrência. Em outro dizer, não a neutralidade decorrente da insipidez do tributo para o agente econômico, mas aqueloutra que deve inspirar condições de igualdade no mercado, a neutralidade concorrencial, que merecerá um tópico infra. ${ }^{103}$

A eficiência econômica, pois, não pode significar um tributo neutro do ponto de vista do investidor, mas um que esteja ajustado aos fins da ordem econômica, atuando para a concretização de seus objetivos. ${ }^{104}$

(ii) Alíquotas tributárias competitivas: a redução de alíquotas parece o caminho político mais simples para aumentar competitividade, uma vez que melhora a relação entre carga tributária e outros fatores locacionais. A redução das alíquotas e a ampliação da base de cálculo iniciada pelos EUA, nos anos 80, tornou-se tendência mundial.

Dados do Relatório da KPMG, intitulado Corporate and Indirect Tax Rates Survey 2010, demonstram ter havido queda na alíquota média global do imposto de renda da pessoa jurídica, no período $2005-2010$ de $27,86 \%$ para $24,99 \%$. No mesmo período a alíquota média dos membros da OCDE decresceu de 28,31\% para 25,94\%. ${ }^{105} \mathrm{O}$ Brasil manteve-se com a imposição de $34 \%$, composta por uma alíquota básica de $15 \%$ e um adicional de $10 \%$ sobre lucros tributáveis que ultrapassarem $\mathrm{R} \$ 240.000,00 /$ ano, ao que vem acrescer uma alíquota de $9 \%$ a título de contribuição social sobre o lucro líquidoCSL.

\section{(iii) Concretização do princípio da capacidade contributiva}

A concretização da capacidade contributiva no contexto da tributação corporativa se dá pelo princípio da renda líquida, que demanda a dedução de gastos necessários à atividade empresarial.

Inobstante a dedução de todas as despesas necessárias à obtenção da renda possa ser impossível, pois esta não é alcançada integralmente pelo legislador, havendo limites, inclusive, de ordem prática- em nome da igualdade deve a renda líquida ser perseguida.

\footnotetext{
${ }^{102}$ SCHOUERI, Luís Eduardo. Direito tributário. São Paulo: Saraiva, 2011, p. 39.

${ }^{103}$ V. II.2.2.4.

${ }^{104}$ SCHOUERI, Luís Eduardo. Direito tributário. São Paulo: Saraiva, 2011, p. 39

${ }^{105} \mathrm{KPMG}$, Corporate and Indirect Tax Rates Survey 2010,p. 29. Disponível em: http://www.kpmg.com/lu/en/issuesandinsights/articlespublications/pages/kpmg'scorporateandindirecttaxrates urvey2010.aspx. Acesso em 07 nov 2011.
} 
Lang cita a reforma da tributação corporativa alemã de 2008, que, para financiar a redução de alíquotas, violou, substancialmente, o princípio da renda líquida objetivo ao vedar deduções com despesas financeiras e prejuízos em um mesmo grupo econômico. Em conclusão, sustenta que transgredir limites da capacidade contributiva abala a competitividade de um dado regime de tributação, já que a vida da empresa fica seriamente em risco em tempos de crise.

\section{(iv) Simplicidade e Transparência na tributação}

Esse é um dos maiores desafios ao Brasil, pois para ser competitivo, um sistema tributário deve ser estruturado em princípios, de forma lógica e coerente. A primeira máxima tributária de Adam Smith - igualdade - unifica capacidade contributiva e benefício. A segunda - certeza- prega um direito tributário o mais compreensível possível. O sistema brasileiro é tão complexo que mesmo tributaristas correm alto risco de aconselharem mal, o que inibe o investidor estrangeiro.

Diversos fatores contribuem para a complexidade de um sistema de tributação da renda. O legislador poderá conferir tratamento diverso a espécies de renda (do trabalho, do capital) ou prever distintas formas de tributação (definitiva na fonte, apuração do lucro real ou presumido). Poderá, igualmente, introduzir diferentes taxas de depreciação conforme a vida útil do bem. Além disso, a tributação estará sempre ligada à própria complexidade social, exigindo incidência sobre diferentes manifestações de riqueza. No caso do Brasil, uma dificuldade a mais resulta da estrutura federativa do País, que, por vezes, gera incidências múltiplas sobre a mesma base econômica. ${ }^{106}$

Do mesmo modo, a transparência das decisões e políticas implantadas é vital para a segurança do investidor estrangeiro. Configurando-se como princípio ético-jurídico implícito na Constituição Federal, a transparência, no dizer de Ricardo Lobo Torres, atua como mecanismo de superação das contradições trazidas pela globalização, marcadas pela insegurança dos capitais voláteis e redução da imposição fiscal sobre as MNEs. ${ }^{107}$

Considerada a pior jurisdição do mundo no que toca ao cumprimento da obrigação tributária, exigindo dos contribuintes a média de 2.600 h/ano enquanto a média mundial perfaz 282h/ano, o Brasil, neste quesito, muito tem a superar. ${ }^{108}$ Medidas de simplificação

\footnotetext{
${ }^{106}$ Cf. L.E.Schoueri, Direito tributário, p. 42.

107 TORRES, Ricardo Lobo. Tratado de direito constitucional financeiro e tributário- valores e princípios constitucionais tributários, v. II. Rio de Janeiro: Renovar, 2005, pp. 244 e 247.

${ }^{108}$ Os dados se referem a todo o sistema tributário brasileiro, sendo a tributação da renda apenas parte do conjunto. V. BANCO MUNDIAL; CORPORAÇÃO FINANCEIRA INTERNACIONAL e
} 
como o SIMPLES para o pequeno e médio empresários, assim como o SPED - Sistema Público de Escrituração Digital -, em implantação nas três esferas de governo, deverão reduzir a burocracia em questão.

Simplicidade, clareza, objetividade e transparência são obrigações de Estado e contribuintes no combate a favorecimentos e corrupção.

(v) Qualidade da administração tributária e segurança no planejamento tributário

Os tributos devem ser formatados para arrecadar ao máximo com o mínimo de despesas da Administração. O contribuinte, para planejar suas disponibilidades de caixa, precisa de segurança no planejamento tributário. Logo, espera do Estado, decisões definitivas, claras e coerentes. Alterações constantes da legislação tributária dificultam o entendimento e aumentam custos para atender as normas. A Constituição Federal, em seu art. 150, expressa notáveis especificações sobre proteção da confiança, ${ }^{109}$ que precisam ser bem disseminadas na seara administrativa, exigindo formação de pessoal conhecedora dos princípios constitucionais, especialmente para o atendimento do contribuinte.

\section{II.2. BALIZAS DO ORDENAMENTO JURÍDICO À CONCORRÊNCIA TRIBUTÁRIA}

II.2.1 O Estado competitivo sob o exame da proporcionalidade

\section{II.2.1.1 Concorrência tributária aceitável e concorrência tributária nociva}

Os efeitos da concorrência tributária internacional dividem a opinião dos países. O que para um pode ser legítima política de incentivos fiscais, para outro pode ser prática concorrencial nociva. A tributação, como dito alhures, ${ }^{110}$ não é o único fator considerado para decisão de alocação do investimento, porém será tanto mais utilizada pelos Estados quanto menos forem estruturados em outros fatores concorrenciais, como localização geográfica, mão-de-obra, insumos, infra-estrutura e segurança. ${ }^{111}$ Do mesmo modo ocorre

PRICEWATERHOUSECOOPERS. Paying taxes 2011: the global picture. Disponível em: http://www.pwc.com/gx/en/paying-taxes/pdf/paying-taxes-2011.pdf. Acesso em 15 dez 2011.

${ }^{109}$ Cf. J. Lang, A tributação das empresas no contexto da concorrência internacional, p. 37

${ }^{110}$ V. item II.1.1, p.56.

${ }^{111}$ OCDE. The OECD's Project on Harmful Tax Practices: The 1998 Report. Disponível em: www.oecd.org. Acesso em 02 nov 2011, p. 15. 
com os Estados cuja base de arrecadação interna seja pequena, pois há pouco a perder em vista do tanto que podem conquistar da base tributária internacional - Luxemburgo seria um exemplo. ${ }^{112}$

A verdade é que a tarefa de distinguir uma concorrência tributária aceitável de uma nociva não é tão simples. Argumentos jurídicos, calcados no ideário de justiça, que admitiam políticas de atração de empreendimentos não são demonstráveis de plano. A OCDE, desde 1998, não tem conseguido discernir ambos os tipos de concorrência, de forma clara. Valendo-se de argumentos políticos, aquela organização sugere que os grandes perdedores no cenário concorrencial seriam os seus membros - países de alta carga tributária, com elevados gastos de seguridade social, educação, defesa nacional. Entretanto, não define as linhas exatas onde práticas aceitáveis tornam-se nocivas.

A simples interação entre sistemas tributários diversos pode ensejar situações absolutamente não intencionais, das quais decorram determinados efeitos nocivos sobre um sistema tributário alhures. Este fenômeno denomina-se mismatching, algo como um acasalamento impróprio, uma união inadequada entre os sistemas tributários. Os mismatchings podem dar guarida a planejamentos tributários estruturados em prejuízo de um ou ambos os Estados. A despeito dos danos que poderão ensejar, os mismatchings não são vistos como nocivos, já que não apresentam a deliberada intenção de erodir a base tributária de outro Estado. ${ }^{113}$

Parece, portanto, que nocividade dependeria, no entendimento da OCDE, de uma postura agressiva, intencional, para desviar fluxos de capital e investimento de outra jurisdição. Seria, em outro dizer, uma invasão da base de tributação pertencente a outro Estado. $^{114}$

É vero, contudo, que a OCDE tenha se valido do contexto de nocividade em seu Relatório 1998, sem que dispusesse, naquela ocasião, de dados empíricos capazes de aferir o desgaste das bases tributárias de seus membros.

\footnotetext{
${ }^{112}$ Cf. P. Genschel, Globalization, tax competition, and the fiscal viability of the welfare state, p. 11.

${ }^{113}$ OCDE. The 1998 Report, p. 15.

114 OCDE. The 1998 Report, p. 16. Mauro Silva se opõe, categoricamente, a esta idéia de que a base de tributação possa pertencer a um Estado. Em suas palavras: "O fenômeno da globalização, há muito tempo, afastou a possibilidade de esse tipo de raciocínio ser sustentado, pois o aumento da mobilidade do capital permite que os pólos geradores de renda sejam deslocados com rapidez sem que o fato de estarem hoje submetidos a determinada soberania fiscal represente qualquer obstáculo para uma mudança." SILVA, Mauro. Da competição à cooperação tributária internacional: aspectos jurídicos da promoção do desenvolvimento nacional num cenário internacionalizado. Tese de Doutorado - Faculdade de Direito da USP, São Paulo, 2009, p.50. Registre-se que essa argumentação fazia mais sentido antes da grande crise econômica, época em que o autor estava escrevendo. Atualmente, há uma preocupação maior dos Estados com a preservação de suas bases, em face das dificuldades financeiras e econômicas, afinal a tributação avança como tema internacional ao passo que os Estados limitam-se a suas fronteiras.
} 
Reuven Avi-Yonah noticia as conclusões a que chegaram dois estudos publicados em 2004. No primeiro, Keen e Simone registraram queda de $20 \%$ na arrecadação do imposto de renda dos PED no período 1990 a 2001, o que não se repetiu nos PD, pois que mantiveram suas receitas estáveis. A queda das receitas nos PED deveu-se à concessão de incentivos fiscais a MNEs, que saltaram, no período, de $45 \%$ para $58 \%$. As principais práticas foram estímulo à exportação (de $32 \%$ para 45\%), redução de alíquotas para pessoas jurídicas (40\% para 60\%) e zonas de livre comércio (de 17,5\% para 45\%). ${ }^{115}$ Já no segundo, Griffith e Klemm não perceberam qualquer evidência de que a tax competition tenha impactado negativamente os membros da OCDE, ${ }^{116}$ que registraram aumento da carga tributária (arrecadação total/PIB) de 29,4\%, em 1975, para 35,9\% em 2006. ${ }^{117}$

Com base no exposto por Avi-Yonah, conclui-se que uma política competitiva adotada pelos PED não evidenciou impacto direto na arrecadação dos $P D$, que se manteve constante na década final e apresentou crescimento no último quartel do sec. XX.

Segundo o Relatório 1998 da OCDE, nociva seria a política concorrencial de determinado Estado que adotasse, concomitantemente:

(i) distorção dos fluxos de investimento real e financeiro;

(ii) corrosão da integridade e justiça dos sistemas fiscais;

(iii) desestímulo ao cumprimento da obrigação tributária pelos contribuintes;

(iv) reformatação do nível desejado e da mescla de tributos e gastos públicos;

(v) alteração da imposição tributária para bases menos móveis como trabalho, propriedade e consumo; e

(vi) aumento dos custos administrativos do fisco e do cumprimento das obrigações (tax compliance) pelos contribuintes. ${ }^{118}$

A adoção de só algumas das práticas acima corresponderá a determinado grau de nocividade a depender de um conjunto de fatores.

Para Michel Rodi, os argumentos da OCDE são pouco consistentes e inibem a dedução científica de concorrência tributária nociva, permanecendo a questão política como principal indicativo para definir fronteiras entre o aceitável e o nocivo em termos de

\footnotetext{
115 KEEN, Michael e SIMONE, Alejandro. Is Tax Competition Harming Developing Countries More Than Developed?, 34 Tax Notes Int'L 1317, 2004 apud AVI-YONAH, Reuven S. The OECD Harmful Tax Competition Report: A Tenth Anniversary Retrospective. University of Michigan Law School, Working Paper No. 115. 2008. Disponível em: http://ssrn.com/abstract=1194942. Acesso em: 05 set 2011, p.10

${ }^{116}$ GRIFFITH, Rachel; KLEMM, Alexander. What Has Been the Tax Competition Experience of the Last 20 Years?, 34 Tax Notes Int'1 1299, 1301, 2004 apud AVI-YONAH, Reuven S., The OECD Harmful Tax Competition Report, p. 11.

${ }^{117}$ Cf. R. S. Avi-Yonah, The OECD Harmful Tax Competition Report, p. 11.

${ }^{118}$ OCDE . Relatório 1998. p. 16
} 
práticas tributárias. Rodi sustenta que mesmo no seio da UUEE os trabalhos restaram inconclusivos (Relatório Ruding,1992), permanecendo a mesma vagueza e contradição dos relatados pela OCDE. ${ }^{119}$

Cumpre, portanto, definir a fronteira que separa a concorrência legítima da nociva sob a óptica jurídica. Tarefa esta da qual o tópico seguinte tentará se desincumbir.

\section{II.2.1.2 Exame de proporcionalidade ${ }^{120}$}

Em sua tese de doutorado pela Faculdade de Direito da Universidade de São Paulo, Mauro Silva propõe interessante alternativa jurídica ao modelo proposto pela OCDE, a que denominou competição tributária internacional aceitável em situações que obedeçam à proporcionalidade voltada para a finalidade de dirimir as desigualdades de desenvolvimento. ${ }^{121}$

Em síntese, Silva propõe a utilização da proporcionalidade como ferramenta jurídica capaz de legitimar a prática competitiva. Valendo-se da lição de Humberto Ávila, ${ }^{122}$ afirma que a proporcionalidade deve ser utilizada sempre que uma medida concreta visar a determinado fim e satisfizer a três testes: adequação, necessidade e proporcionalidade stricto sensu. Como, no presente caso, tem-se uma medida concreta expressa pela concessão de incentivos fiscais - implantada para a consecução de um fim precípuo - "aumento do nível de desenvolvimento ou a realização mais ampla possível do direito ao desenvolvimento"-, ${ }^{123}$ resulta daí a aplicação da proporcionalidade.

\footnotetext{
${ }^{119}$ Cf. M. Rodi, Concorrência tributária internacional por investimentos, p. 133.

${ }^{120}$ A proporcionalidade é tida por princípio, regra, máxima ou postulado, como pontua Virgílio Afonso da Silva. De princípio não se pode tratar, pois que impõe um dever definitivo e não uma realização máxima possível ante circunstâncias fáticas e jurídicas do caso concreto. Tampouco máxima parece boa indicação, por ter origem no idioma alemão e sugerir não um dever, mas uma recomendação. Postulado seria o termo preferido por Humberto Ávila, e regra, pelo próprio Virgílio. Trata-se, em suma, de uma regra sobre a aplicação de outras regras, portanto uma meta-regra ou regra de segundo nível, a que se poderá chamar postulado, pois que se define nesse mesmo sentido. V. SILVA, Virgílio Afonso da. Direitos fundamentais: conteúdo essencial, restrições e eficácia.São Paulo: Malheiros Editores, 2011, p. 168. Humberto Ávila, sobre o tema, pontua que a denominação é secundária, mas os postulados não podem ser tidos por princípios por questões de inconsistência científica e não somente de nomenclatura. Assim, os postulados não são normas finalísticas, realizáveis em vários graus, com elevado grau de abstração e generalidade, mas antes normas metódicas, que estruturam a aplicação de outras normas de forma racional e que conferem critérios precisos para a aplicação do Direito. Cf. H. B. Ávila, Teoria dos princípios, p. 125. Por todo o exposto, para os fins deste trabalho, a proporcionalidade poderá ser tida por postulado ou regra de segundo nível. Maior aprofundamento sobre a terminologia classificatória da proporcionalidade está além do escopo desta tese.

${ }^{121}$ Cf. M. Silva, Da competição à cooperação tributária internacional, p.50.

122 ÁVILA, Humberto. Teoria dos princípios - da definição à aplicação dos princípios jurídicos, 10. ed. São Paulo: Malheiros Editores, 2009, pp. 163-178.

${ }^{123}$ Cf. M. Silva, Da competição à cooperação tributária internacional, pp.52-53.
} 
A concessão de incentivos seria uma das medidas capazes de promover o desenvolvimento, satisfazendo, pois, o teste da adequação.

Necessidade pressupõe a existência de outros meios capazes igualmente de promover o fim, porém com menores efeitos restritivos sobre direitos fundamentais. ${ }^{124} \mathrm{O}$ resultado desse teste depende de exame pontual sobre o caso concreto, já que, como visto alhures, ${ }^{125}$ há outros fatores não-tributários capazes de influir na alocação do IED. ${ }^{126}$

No teste da proporcionalidade stricto sensu, importa saber se "as vantagens trazidas pela promoção do fim correspondem às desvantagens provocadas pela adoção do meio", ${ }^{127}$ o que importa alto grau de subjetividade na definição do que vem a ser vantagem e desvantagem. A esse respeito, Mauro Silva também conclui pela análise pontual, identificando potenciais prejuízos à soberania fiscal e à arrecadação de um Estado, bem como sobre a perda de efeitos de contágio (spillover effects) que seriam trazidos por determinado IED que fora realizado em outro Estado. ${ }^{128}$

Conclui sua análise no sentido de que a concorrência tributária não pode ser taxada de aceitável ou nociva sem uma análise casuística que tome a proporcionalidade como seu elemento estruturador. $^{129}$

Embora se aplauda a juridicidade que o crivo da proporcionalidade empresta à análise de nocividade da concorrência tributária internacional, reduzindo a vagueza das definições da OCDE, à teoria em comento poder-se-ia acrescer o quanto segue.

De início, cumpre ressaltar que o uso da proporcionalidade é poderoso instrumento de controle sobre atos do Poder Público. ${ }^{130} \mathrm{O}$ êxito de sua aplicação depende da identificação precisa da relação meio/fim, afinal um "meio cujos efeitos são indefinidos e um fim cujos contornos são indeterminados, se não impedem a utilização da proporcionalidade, certamente enfraquecem seu poder de controle". ${ }^{131}$

Logo, fundamental indagar se a medida concreta incentivos fiscais estará realmente apta a promover desenvolvimento. Ademais, seria o desenvolvimento um resultado concreto, aferível ao ponto de permitir que se avaliem as restrições impostas pelo meio empregado?

\footnotetext{
${ }^{124}$ Cf. H. Ávila, Teoria dos princípios, p. 172.

${ }^{125} \mathrm{~V}$. item II.1.1.

${ }^{126}$ Cf. M. Silva, Da competição à cooperação tributária internacional, p.53.

${ }^{127}$ Cf. H. Ávila, Teoria dos princípios, p. 164.

${ }^{128}$ Cf. M. Silva, Da competição à cooperação tributária internacional, p.54.

${ }^{129}$ Cf. M. Silva, Da competição à cooperação tributária internacional, p.54.

${ }^{130}$ Cf. H. Ávila, Teoria dos princípios, p. 165

${ }^{131}$ Cf. H. Ávila, Teoria dos princípios, p. 165.
} 
O desenvolvimento econômico é algo complexo, que não pode ser medido por uma única variável. A renda per capita é exemplo clássico disso, pois pode apresentar bom índice, mas ocultar péssima distribuição de renda em dado país. O mesmo raciocínio pode ser empregado para outras variáveis, como industrialização, crescimento do PIB, domínio de tecnologias ou bem-estar social.

Exigiria, o desenvolvimento, na lição de Fábio Nusdeo, uma "série infindável de modificações de ordem qualitativa e quantitativa, de tal maneira a conduzir a uma radical mudança de estrutura da economia e da própria sociedade do país em questão." 132

Neste ponto, pode ser adicionada a visão singular de Amartya Sen, segundo a qual o desenvolvimento deve ser entendido como processo de expansão de liberdades reais de que as pessoas desfrutam. Para conquistar o desenvolvimento sob este enfoque, um país precisa remover as fontes de privação de liberdade: pobreza e tirania, carência de oportunidades econômicas, destituição social sistemática, negligência de serviços públicos, intolerância ou interferência de Estados repressores. ${ }^{133}$

Logo, um processo sustentado, contínuo, complexo, conquistado, capaz de promover radical alteração da estrutura econômica e social de um país, removendo-lhe as fontes de privação de liberdades pessoais, não se permite aferir, de plano, como um fim juridicamente definível. Isso torna o exame de proporcionalidade, quanto à medida concessão de incentivos fiscais, pouco consistente.

Tome-se, por exemplo, a concessão de incentivos fiscais para a atração de uma determinada MNE que acaba por se fixar no Estado indutor. Seria possível, nestas circunstâncias, assegurar que a medida foi exitosa em desenvolver o país? Acaso, os serviços públicos melhoraram ou as decisões das cortes administrativas ou judiciárias tornaram-se mais coerentes e céleres por conta da chegada da nova empresa? Adotando-se o enfoque Nusdeo-Sen, a qualidade dos serviços públicos, assim como a segurança e a harmonia das decisões das cortes tributárias podem ser tomadas como índices de desenvolvimento, pois, além de aumentarem as liberdades individuais, representam mudança estrutural de alto impacto sócio-econômico.

Por esta vereda, talvez fosse mais adequada a aplicação do postulado pensando no fim atração de IED, que de per se já ensejaria dificuldades, pois é difícil aferir, com certeza, se as razões que influenciaram na decisão de instalação de uma MNE foram

\footnotetext{
${ }^{132}$ Cf. F. Nusdeo, Curso de economia, p. 347.

${ }^{133}$ SEN, Amartya Kumar. Desenvolvimento como liberdade. Tradução Laura Teixeira Motta; revisão técnica Ricardo Doniselli Mendes. 8. ed. São Paulo: Companhia das Letras, 2009, pp.17-18.
} 
ligadas aos incentivos fiscais recebidos e em que medida. Há miríade de fatores que impressionam o investidor, de modo que graduar o quanto de cada fator terá sido capaz de influenciar sua decisão é tarefa difícil, senão impossível.

Tais dificuldades crescem com a imposição do fim desenvolvimento, já que o conceito é ainda mais vago, razão pela qual opta-se pela atração de IED como a finalidade perseguida pela medida avaliada sob o crivo da proporcionalidade.

Do ponto de vista brasileiro, é recorrente a justificativa de parlamentares quando atendem ao lobby de determinado setor, no sentido de que os generosos incentivos fiscais ofertados trarão emprego, renda e aumento do bem-estar da população do local que receber o IED. Tais justificativas podem ser tomadas como sinônimo de desenvolvimento.

Entretanto, não há qualquer controle objetivo capaz de confrontar o quanto de benefícios sociais e econômicos a perda de arrecadação dos incentivos fiscais efetivamente produziu.

Após essas digressões, oportuno observar os testes de necessidade e proporcionalidade stricto sensu.

Quanto ao primeiro, indaga-se se há disponíveis outros meios indutores do desenvolvimento ou a concessão de incentivos fiscais é medida necessária? A resposta a esta questão requer se retorne à teoria dos fatores locacionais, que demonstra haver uma série de subfatores capazes de influenciar na atração do IED. Logo, o uso da norma tributária indutora é uma das vias possíveis, mas não a única.

A dificuldade desse exame está em comparar os meios e seus desempenhos na consecução do fim almejado, já que um "meio não é, de todos os pontos de vista, igual a outro." ${ }^{34}$ Assim, enquanto um meio pode ser mais ou menos oneroso, complexo, incerto, difícil, fato é que, levado ao extremo, o teste da necessidade jamais aprovaria qualquer meio empregado, por sempre ser possível, ao menos sob um aspecto específico, constatar um meio promotor do fim almejado em melhores condições do que o utilizado. ${ }^{135}$

Por este prisma, em tendo sido a norma tributária indutora escolhida pelo legislador como o meio adequado para atração de IED, ele só deve ser afastado se flagrantemente menos adequado que outro. ${ }^{136}$

Sob o aspecto da proporcionalidade em sentido estrito, vale saber se as restrições causadas aos direitos fundamentais, pela concessão pontual de incentivos fiscais, justificam

\footnotetext{
${ }^{134}$ Cf. H. Ávila, Teoria dos princípios, p. 173.

${ }^{135}$ Cf. H. Ávila, Teoria dos princípios, p. 173.

${ }^{136}$ Cf. H. Ávila, Teoria dos princípios, p. 173.
} 
a promoção do fim atração de IED. Neste ponto, a análise exige que se veja a questão sob dois ângulos distintos: juridicidade doméstica e internacional.

Adiante-se, porém, que a perda dos efeitos de contágio (spillover effects) não pode ser encarada como resultado da aplicação da proporcionalidade. Para dar supedâneo a esta asserção, suponha-se que determinado Estado entre na concorrência por uma MNE concedendo altos incentivos fiscais a fim de atrair o capital. O fim é a atração do IED. Se ele não se configura, quebra-se o necessário elo meio-fim para que se possa comparar a consecução exitosa de um fim em face da restrição suportada pela sociedade em termos de direitos fundamentais.

Não há, neste caso, vantagens conseguidas pela consecução do fim pretendido atração do IED - que permitam proceder à comparação com o ônus da adoção do meio empregado. Em outro dizer, a concessão de incentivos pode ter causado distorções em face da igualdade ou mesmo ter impactado o orçamento de forma negativa, sem que a tais ônus corresponda qualquer benefício que a chegada do IED pretensamente traria.

Do que aqui se expôs, resulta que a proporcionalidade será, doravante, tomada como o exame necessário para o fim de indução do agente econômico a investir no País. A justificação da norma impositiva, de fim eminentemente fiscal, toma a capacidade contributiva como critério diferenciador dos contribuintes. Já a norma tributária indutora, atendendo à finalidade estatal diversa da arrecadação, terá critérios conformes seus objetivos extrafiscais que deverão, ao máximo, preservar a capacidade contributiva, exigindo a aplicação do postulado da proporcionalidade.

Humberto Ávila bem explica que a proporcionalidade representa o único meio de preservar a finalidade econômica ou social da norma tributária, paralelamente à preservação máxima da capacidade contributiva. $\mathrm{Na}$ verdade, o Estado tem diversos fins que podem justificar o modo de instituição dos impostos. Neste sentido, ainda que o legislador tenha outra finalidade que não a arrecadação (atração de IED), exige-se a preservação, ainda que não como finalidade do encargo, mas como ponto de referência da ponderação a ser feita, da capacidade contributiva. ${ }^{137}$

\section{II.2.2 Critérios informadores da tributação da renda no Brasil}

137 ÁVILA, Humberto Bergmann. Conceito de renda e compensação de prejuízos fiscais. São Paulo: Malheiros Editores, 2011, pp. 25-27. 
O Sistema Tributário Nacional, grafado no capítulo I do Título VI - Da Tributação e do Orçamento da Constituição Federal, encerra um conjunto fundamental de princípios e regras que traduzem o gênio do Estado Democrático de Direito. Em verdade, decorre da interpretação sistemática da Carta Política a plena vigência de outros princípios que figuram no ordenamento tributário, muito embora implícitos no texto constitucional. ${ }^{138}$

Como o contexto deste trabalho não reside na análise dos diversos princípios do ordenamento pátrio, entende-se mais apropriado não se opor ao já arraigado termo princípio que antecede cada uma das limitações ao poder de tributar - princípio da legalidade, princípio da anterioridade, princípio da irretroatividade etc.-, independente de expressarem realmente princípios ou regras. ${ }^{139}$ Ademais, pode-se constatar que um mesmo comando constitucional pode conter, simultaneamente, princípios (mandados de otimização) e regras, uma vez que de um mesmo enunciado é possível extrair várias normas. ${ }^{140}$

A tributação no Estado Democrático deve primar pela busca da justiça, que, segundo Tipke, se apóia nos princípios da igualdade, do Estado Social e da liberdade. ${ }^{141}$

O princípio do Estado Social tem por fim realizar justiça social, o que não é possível concretizar somente pela coluna da arrecadação. Há que se observar também uma distribuição justa, o que conduz o tema para o âmbito do direito financeiro, já que importará direcionar os gastos públicos aos mais necessitados, prioritariamente.

Assim, pode-se traduzir o princípio do Estado Social por princípio da solidariedade ${ }^{142}$ sabendo-se que arrecadação socialmente justa impõe maior ônus aos mais aquinhoados e menor ônus aos mais necessitados e que caberá ao Estado distribuir o montante arrecadado, priorizando os mais pobres.

\footnotetext{
${ }^{138}$ Malgrado a distinção entre princípios e regras justifique aprofundado estudo, em linhas básicas, a menos que se ressalve, por princípios serão entendidos mandados de otimização, cuja realização pode se dar em diversos graus no caso concreto. Por regras, garantem-se direitos ou impõem-se deveres de forma definitiva, o que significa que devam ser realizados (garantia do direito ou a imposição do dever) integralmente, no caso concreto. Cf. V.A.da Silva, Direitos fundamentais: conteúdo essencial, restrições e eficácia, pp. 44-45.

${ }^{139}$ Maior aprofundamento acerca do tema está fora do escopo desse trabalho. Para maiores reflexões acerca da distinção entre princípios regras, V. ÁVILA, Humberto. Teoria dos princípios - da definição à aplicação dos princípios jurídicos, 10. ed. São Paulo: Malheiros Editores, 2009; GRAU, Eros Roberto. A ordem econômica na Constituição de 1988 -interpretação e crítica. 8.ed. São Paulo: Malheiros editores, 2003, pp.135-149; DWORKIN, Ronald, O império do direito. São Paulo:Martins Fontes, 1999; e ALÉXY, Robert. Teoria dos direitos fundamentais. 2. ed. São Paulo: Malheiros, 2011; SILVA, Virgílio Afonso da, Direitos fundamentais, conteúdo essencial, restrições e eficácia.São Paulo: Malheiros Editores, 2011.

${ }^{140}$ SCHOUERI, Luís Eduardo. Direito tributário. São Paulo: Saraiva, 2011, p.267.

${ }^{141}$ TIPKE, Klaus; YAMASHITA, Douglas. Justiça fiscal e princípio da capacidade contributiva. São Paulo: Malheiros Editores, 2002, pp. 17-18.

${ }^{142}$ Cf. K. Tipke, Justiça fiscal e princípio da capacidade contributiva, p. 43.
} 
Não por acaso, o art. $3^{\circ}$, I da CF coloca a construção de uma sociedade livre, justa e solidária como objetivo fundamental da República Federativa do Brasil. Em matéria tributária, a justiça fiscal se reveste da mais alta estatura, vetor máximo a determinar a aplicação dos demais princípios e regras em suas interseções, que não poderá ser efetivada se a liberdade de um contribuinte for violada ou se a arrecadação não distinguir a real possibilidade de contribuir de cada integrante, ferindo a solidariedade.

Cumpre indagar, portanto, se seria justo excluir da tributação aquele que detém comprovada capacidade contributiva onerando o que a possui em menor grau? Aqui se encontra um dos mais difíceis temas do direito tributário da pós-modernidade. A oferta de incentivos fiscais supostamente justificados pela atração de IED e, em último grau, de desenvolvimento, deixa severas dúvidas acerca de sua legitimidade, pois que, a priori, vai de encontro ao princípio amplamente reconhecido para concretização da justiça em matéria tributária: a igualdade medida pela capacidade contributiva.

Daí a importância da teoria de Tipke acerca da justiça fiscal, ao exportar o que os alemães chamam de justiça adequada à matéria. ${ }^{143}$ Assumindo que não há um critério único aplicável a todo o Direito, deve-se escolher um critério adequado a cada ramo do Direito, a depender dos fins a que este se propõe. ${ }^{144}$ Como a atuação do direito tributário pode se ancorar na fiscalidade ou na indução, os critérios específicos para aplicação à matéria tributária divergirão conforme a atuação do direito tributário.

Amplamente reconhecida como critério arrecadador, a capacidade contributiva tem mitigada valia ao ser aplicada à matéria tributária, nas ocasiões em que esta se voltar para a indução do agente econômico.

Critérios válidos para a indução poderiam ser, por exemplo, o fomento a P\&D e ao desenvolvimento tecnológico, a redução de desigualdades regionais ou a diferenciação ao microempresário. Todavia, ainda que tais critérios sejam ditados pelo próprio constituinte, não podem ser vistos como absoluta liberdade ao legislador para definir seus contornos e nem ao aplicador da lei para garantir-lhes a concreção. Ambos estão, inexoravelmente, vinculados à justiça fiscal, cujo eventual afastamento enseja violação à ordem jurídica e ao Estado de Direito.

\footnotetext{
${ }^{143}$ Segundo Tipke, as Constituições dos Estados de Direito não permitem a dissociação entre direito positivo e ética. Neste giro, a Constituição Brasileira impõe a igualdade perante à lei como direito fundamental. Ocorre que o tratamento isonômico como corolário da justiça exige um critério adequado de comparação. Como não pode haver um critério aplicável uniformemente para todo o Direito, cumpre observar cada ramo do Direito para decidir sobre um critério que melhor se lhe aplique. Cf. K. Tipke , Justiça fiscal e princípio da capacidade contributiva, p. 21.

${ }^{144}$ Cf. K. Tipke, Justiça fiscal e princípio da capacidade contributiva, p. 21
} 
Segundo Humberto Ávila, os contribuintes podem ser diferenciados por critérios outros que não a capacidade contributiva, caso os impostos tenham uma justificação e uma finalidade extrafiscal. Justificações diversas conduzem ao uso de critérios diferentes. Assim, as múltiplas tarefas do Estado terão justificações diversas. Quando a tarefa estatal não se relacionar a características pessoais do contribuinte - por exemplo, ao realizar os princípios da atividade econômica (art. 170, CF), a evolução da ciência e da tecnologia (arts. 218 a 224, CF), ou a proteção do meio-ambiente (art. 225, CF) -, o critério de aplicação da igualdade entre sujeitos passivos não será capacidade contributiva. Todavia, à eleição de um critério justificador da norma indutora soma-se o dever de preservação máxima da capacidade contributiva, o que exige a aplicação do postulado da proporcionalidade, único meio de preservação máxima de ambas as finalidades em questão. $^{145}$

Com vistas e evitar o arbítrio, deve o legislador bem definir a finalidade extrafiscal, já que esta não poderá resultar em excessiva violação da igualdade. Em suma, a indução estará justificada se o tratamento desigual que produzir somente atingir casos excepcionais ou, com intensidade mínima, atingir muitos casos. ${ }^{146}$

\section{II.2.2.1 Igualdade}

\section{II.2.2.1.1 Capacidade contributiva e solidariedade}

Verdadeiro corolário da igualdade em matéria de impostos, a capacidade contributiva divide-se em absoluta ou objetiva e relativa ou subjetiva. Isto se deve à dupla caracterização da capacidade contributiva, que ora pode servir à gradação do tributo (subjetiva), ora a distinguir situações tributáveis de não-tributáveis (objetiva). ${ }^{147}$

A capacidade contributiva objetiva atua como parâmetro fronteiriço entre as situações tributáveis e não-tributáveis, segregando, na sociedade, aqueles que serão contribuintes por indiciarem capacidade de contribuir. Fica o legislador, destarte, tolhido de escolher hipótese de incidência que não revele capacidade contributiva. No caso do imposto de renda, quem não auferir renda, não poderá constar do rol dos que deverão

${ }^{145}$ Cf. H.. B. Ávila, Conceito de renda e compensação de prejuízos fiscais. São Paulo: Malheiros Editores, 2011, pp. 25-26.

${ }^{146}$ Cf. H. B. Ávila, Conceito de renda e compensação de prejuízos fiscais, p. 27.

${ }^{147}$ Cf. L.E. Schoueri, Direito tributário, 312. 
suportar a tributação. Trata-se, pois, de regra do ordenamento que obriga o legislador a prever hipóteses tributárias objetivamente reveladoras de capacidade contributiva. ${ }^{148}$

Já a capacidade contributiva subjetiva se aplica a todos os tributos, definindo o espaço mínimo e o máximo em que será possível a imposição fiscal. O limite mínimo indica o mínimo existencial; o máximo impede o confisco. Aqueles que não dispõem de recursos para subsistir, ainda que indiciem capacidade econômica, não possuem capacidade contributiva. Do mesmo modo, se a tributação é onerosa ao ponto de ultrapassar a capacidade de contribuir do sujeito passivo, ela será descabida. Neste sentido, seria, a capacidade contributiva, verdadeiro princípio, mandado de otimização a que o legislador buscaria concretizar ao máximo. ${ }^{149}$

A previsão constitucional do artigo $145, \S 1^{\circ}$ - sempre que possível, os impostos terão caráter pessoal e serão graduados segundo a capacidade econômica do contribuinte- diz com a capacidade contributiva objetiva, já que sua aplicação aos impostos exige que se observe a vedação do $\S 2^{\circ}$ do mesmo artigo - taxas não poderão ter base de cálculo própria de impostos. No Brasil, portanto, a base de cálculo própria de impostos indicia riqueza, o que é desnecessário para taxas, espécie que se justifica pelo sinalagma e não pela solidariedade. ${ }^{150}$

Em sua faceta subjetiva, porém, a capacidade contributiva não pode se confundir com a capacidade econômica. ${ }^{151}$ Apesar do viés economista da equiparação entre ambas, a simples individualização das condições de cada contribuinte já impõe distinção nítida no bojo da tributação da renda. Ao preservar o mínimo existencial, como signo da liberdade e da dignidade humana, o ordenamento brasileiro impõe não se atinja algo que está aquém

\footnotetext{
${ }^{148}$ A capacidade tributária objetiva é aplicável somente aos impostos, nos termos do art. $145, \S 1^{\circ}$ da $\mathrm{CF}$, Cf. L.E. Schoueri, Direito tributário, 314. Neste mesmo sentido, Regina Helena Costa, Praticabilidade e justiça tributária, pp.114-115.

${ }^{149}$ Cf. L.E. Schoueri, Direito tributário, 313.

${ }^{150}$ Do mesmo modo com relação às contribuições especiais, cujo critério diferenciador se encontra primeiro na referibilidade, ou seja, em pertencer ou não a um dado grupo e, num segundo estágio, já dentro do grupo, na capacidade contributiva para diferenciar os integrantes do grupo. Cf. L.E. Schoueri, Direito tributário, pp. 314-315.

${ }^{151}$ Humberto Ávila explica que a "observância da capacidade contributiva faz com que, primeiro, os tributos devam ser graduados segundo a capacidade econômica. O substrato econômico na hipótese de cada imposto é pressuposto pela própria Constituição. Sendo assim, só podem ser tributadas as atividades relacionadas à renda, patrimônio ou consumo, que sejam indicativas de expressão econômica. A capacidade produtiva não deve ser tributada, mas somente a riqueza efetivamente percebida. Nesse sentido, afastam-se tanto a tributação de rendimentos meramente nominais, decorrentes da inflação, quanto a tributação de riquezas meramente prováveis por meio de ficções e presunções absolutas.”. Cf. H. Ávila, Teoria da Igualdade tributária, p. 161.
} 
da capacidade contributiva e nem o que está além, caracterizado por confisco - este com vedação expressa no art. $150, \mathrm{IV}$ da $\mathrm{CF} .{ }^{152}$

Não por outra razão, a redução da base de cálculo do imposto de renda para preservar a sustentação do sujeito passivo e de seus dependentes é obrigatória quando se persegue a justiça fiscal. Por decorrência, a capacidade contributiva subjetiva deve apurar o montante da renda disponível para o adimplemento da obrigação tributária, a menos que se espere que o contribuinte se desfaça de seus bens para arcar com o imposto. ${ }^{153}$

Quanto mais alta a renda, mais alto deve ser o imposto. Esta máxima exprime a idéia de solidariedade e de igualdade, já que representa uma via discriminatória de contribuintes, cujo critério é a capacidade contributiva. Do mesmo modo, as balizas do mínimo existencial e do confisco representam limites à tributação colocados pela igualdade e pela liberdade.

A igualdade em si é vazia, ${ }^{154}$ necessitando de critérios justos para ser aplicada quanto à tributação. Por critério justo não se pode entender aquele dissociado do fim distributivo solidário, razão pela qual se exige a escolha de um critério adequado para bem justificar a diferenciação no tratamento dos contribuintes. ${ }^{155}$ Assim, o constituinte mesmo já tratou de elencar alguns parâmetros inaceitáveis para discriminação, como o que veda qualquer distinção em razão de ocupação profissional ou função exercida (art. 150, II) ou o que veda privilégios a empresas públicas e sociedades de economia mista (art. 173, $\left.\S 2^{\circ}\right) .{ }^{156}$

Schoueri entende que a justificação das espécies tributárias permite encontrar o critério adequado para discriminar o tratamento dos contribuintes à luz da igualdade. Assim, as taxas justificam-se pelo sinalagma, atendendo-se à igualdade na medida em que se tributa aquele que utilizou o serviço público ou o teve ao dispor, ou, ainda, aquele que deu ensejo ao exercício do poder de polícia. ${ }^{157}$

O que justificaria a diferença de imposição de um imposto seria a capacidade contributiva, expressão da solidariedade. Em outro giro, compete ao legislador escolher um critério que segregue os que podem contribuir dos que não podem, visando a impor uma colaboração solidária para atingir objetivos que beneficiem a toda a coletividade. ${ }^{158}$

\footnotetext{
${ }^{152}$ Cf. R. L. Torres, Tratado de direito constitucional financeiro e tributário, v. III, p. 305.

153 TIPKE, Klaus. Sobre a unidade da ordem jurídica tributária. In: SCHOUERI, L.E. e ZILVETI, F. A. (coord.), Direito tributário - Estudos em homenagem a Brandão Machado. São Paulo: Dialética, 1998, p. 63.

${ }^{154}$ Cf. R. L. Torres, Tratado de direito constitucional financeiro e tributário, v. III, p. 152.

${ }^{155}$ Cf. K. Tipke, Justiça fiscal e princípio da capacidade contributiva, p. 21.

${ }^{156}$ Cf. L.E. Schoueri, Direito tributário, 310.

${ }^{157}$ Cf. L.E. Schoueri, Direito tributário, 311.

${ }^{158}$ Cf. L.E. Schoueri, Direito tributário, 311.
} 
Não é, contudo, a capacidade contributiva, o único parâmetro a ser utilizado quanto a impostos. Na verdade, a igualdade não se prende a um só fundamento, eis que é passível de ser justificada por motivos fiscais ou indutores. ${ }^{159}$ Em atenção a estes últimos, é possível diferenciar contribuintes com a mesma capacidade contributiva em nome do desenvolvimento regional ou mesmo de valores consagrados pela ordem econômica, tais como a livre concorrência. ${ }^{160}$

$\mathrm{Na}$ verdade, diversos parâmetros coexistem no ordenamento tributário, cumprindo verificar a existência de fator capaz de justificar eventual discriminação entre dois ou mais contribuintes que tenham a mesma capacidade contributiva. Evoca-se, neste ponto, a lição de Schoueri, ${ }^{161}$ em que cada fator representa um corte no mundo fenomênico, separando os que satisfazem dos que não satisfazem aos reclames do fator. Com a interseção de diversos cortes restarão fatias cada vez menores, podendo-se avaliar a igualdade dentro de cada fatia assim como entre fatias.

A igualdade dentro da fatia (horizontal) já expressa o resultado da compatibilização entre capacidade contributiva e outros fatores constitucionalmente previstos, pois esses realizaram os cortes dos quais a fatia é resultante. Já entre fatias (igualdade vertical), a igualdade exige verificar se há diferença suficiente capaz de justificar o tratamento divergente. Para tanto, observa-se que a medida do corte que segrega contribuintes em situação até então equivalentes é a razoabilidade, que opera como dever de vinculação entre duas grandezas, ou seja, exige uma relação de equivalência entre critério e medida.

Além da razoabilidade, o dever de medida pela proporcionalidade deve ser utilizado para garantir a juridicidade da norma tributária indutora.

\section{II.2.2.1.2 Progressividade e Proporcionalidade}

Foi escolha do constituinte sujeitar o imposto de renda ao critério da progressividade (art. $153, \S 2^{\circ}, \mathrm{CF}$ ), ${ }^{162}$ todavia esta não é uma exigência da capacidade

\footnotetext{
${ }^{159}$ Cf. R. L. Torres, Tratado de direito constitucional financeiro e tributário, v. III, p. 153. Tipke, neste mesmo sentido assevera que o direito tributário seja orientado pela capacidade contributiva, o que não vale, porem, para normas indutoras. Cf. Tipke e D. Yamashita, Justiça fiscal e princípio da capacidade contributiva, p. 21.

${ }^{160}$ Cf. L.E. Schoueri, Direito tributário, 315. Neste mesmo sentido, H.B. Ávila, Conceito de renda e compensação de prejuízos fiscais,p. 25.

${ }^{161}$ Cf. L.E.Schoueri, Direito tributário, pp. 315-316.

${ }^{162}$ Schoueri qualifica a progressividade e a proporcionalidade como princípios específicos, em contraposição aos princípios gerais de aplicação a todos (ou quase) tributos. Já Ricardo Lobo Torres as entende como
} 
contributiva enquanto princípio aberto e indeterminado, para cuja concretização há opções outras de parâmetros como a proporcionalidade, generalidade, ${ }^{163}$ universalidade ${ }^{164} \mathrm{e}$, fora do escopo do imposto de renda, seletividade e personalização. ${ }^{165}$

Na proporcionalidade, a alíquota é fixa e a base de cálculo, à medida que aumenta, produz maior tributação atendendo aos reclames da igualdade.

Já a progressividade exige aumento de alíquotas por faixa de rendas, discriminando o tratamento dos sujeitos passivos conforme cresça a base de cálculo. No Brasil, a progressividade do imposto de renda pessoa física-IRPF a partir de 2011 está discriminada na seguinte tabela:

\begin{tabular}{|l|c|c|}
\hline $\begin{array}{c}\text { Base de cálculo mensal em } \\
\mathbf{R} \$\end{array}$ & $\begin{array}{c}\text { Alíquota } \\
\%\end{array}$ & $\begin{array}{c}\text { Parcela a deduzir do imposto em } \\
\mathbf{R} \$\end{array}$ \\
\hline Até $1.499,15$ & - & - \\
\hline De $1.499,16$ até $2.246,75$ & 7,5 & 112,43 \\
\hline De $2.246,76$ até $2.995,70$ & 15,0 & 280,94 \\
\hline De $2.995,71$ até $3.743,19$ & 22,5 & 505,62 \\
\hline Acima de $3.743,19$ & 27,5 & 692,78 \\
\hline
\end{tabular}

\section{II.2.2.2 Praticabilidade}

A aplicação rigorosa da capacidade tributária na aferição das situações individuais exigiria volume de recursos humanos e financeiros extraordinários da administração pública, sem a garantia que a pretendida igualdade fosse conseguida em todos os casos. Esta situação se agrava sob o enfoque da tributação internacional, onde informações

subprincípios da capacidade contributiva. V. L.E.Schoueri, Direito tributário, p.353 e R.L.Torres, Curso de direito tributário, pp. 94 e 376.

163 Os critérios da generalidade e universalidade informam o imposto de renda por determinação constitucional (art. 153, §2 $2^{\circ}$ ), revestindo-se, ambos, da natureza de parâmetros (subprincípios) da capacidade contributiva. Pela submissão da generalidade de pessoas ao imposto de renda, todos os residentes possuidores de capacidade contributiva devem suportar o ônus da tributação. Não há espaço para discriminações em função de qualquer critério que não diga com a riqueza. Assim, por exemplo, a generalidade impede o reconhecimento da isenção de magistrados ao imposto de renda que já vigeu dentre nós. Cf. R. L. Torres, Tratado de direito constitucional financeiro e tributário, v. III, p. 328.

${ }^{164}$ A universalidade impõe que a tributação alcance a totalidade das rendas dos residentes, independente de terem sido produzidas no Brasil ou no exterior.

165 A seletividade informa o IPI e o ICMS. A personalização figurou na CF de 1946, art. 202, e atinge o imposto causa mortis. Cf. R.L.Torres, Curso de direito tributário, p.94. 
preciosas para a individualização da renda dos contribuintes podem estar sujeitas a jurisdições estrangeiras, dependendo, pois, de eficaz rede de cooperação entre Estados.

Ganham importância, neste ponto, as normas de simplificação, que podem atuar, dentro de limites, a benefício do próprio funcionamento do sistema tributário. Da aplicação dessas normas pode resultar tratamento desigual ante situações equivalentes ou igual tratamento ante situações distintas. A exigência para tanto está em que o ganho em praticabilidade não produza excessivo prejuízo à justiça no caso concreto. ${ }^{166}$

Em outro dizer, a praticabilidade efetua um corte no mundo fenomênico que intercepta o corte da capacidade contributiva, ensejando tratamento diferenciado a situações equivalentes. O ganho trazido pela simplificação será tido por constitucional se satisfizer ao exame de proporcionalidade e se adequar ao postulado da razoabilidade.

Para Regina Helena Costa, a praticabilidade ou praticidade seria um princípio implícito que se manifesta por um "conjunto de técnicas que visam a viabilizar a adequada execução do ordenamento jurídico", e que está definitivamente ligado à igualdade e à capacidade contributiva na busca pela justiça tributária. ${ }^{167}$

Esta conclusão não está isenta de críticas. Com efeito, não se pode sustentar um vínculo indissociável entre a praticabilidade, a igualdade e a capacidade contributiva. A igualdade em matéria de imposto de renda exigiria que se observasse todo o período possível de acumulação de renda por parte do contribuinte. Se pessoa física, o tempo de sua vida. Se jurídica, o tempo de atividade da empresa. A apuração anual do imposto de renda atende a reclames de praticabilidade, afastando, ao invés de unir indissoluvelmente, a capacidade contributiva e a igualdade. ${ }^{168}$

Exceções (à igualdade) dessa natureza exigem rigoroso acompanhamento, por consagrarem medidas de normalidade média, ou seja, que não visam ao privilégio demasiado de uns em detrimento do todo. Todas as medidas excepcionais devem considerar a média dos contribuintes. No exemplo do mínimo vital, deve-se avaliar qual o valor capaz de conferir dignidade à média dos contribuintes, valor este que não deve comportar extravagâncias. ${ }^{169}$

A conveniência do Estado para atuar encontra limites na capacidade contributiva. A conciliação entre praticabilidade e igualdade impõe sejam observados períodos pretéritos e

\footnotetext{
${ }^{166}$ Cf. K. Tipke, Justiça fiscal e princípio da capacidade contributiva, pp. 38-39.

${ }^{167}$ COSTA, Regina Helena. Praticabilidade e justiça tributária. São Paulo: Malheiros Editores, 2007, pp. 53 e 109.

${ }^{168}$ Cf. L.E. Schoueri, Direito tributário, 360.

${ }^{169}$ Cf. K. Tipke, Justiça fiscal e princípio da capacidade contributiva, pp. 38-39.
} 
futuros na apuração do imposto de renda. O corte temporal para aferir variação patrimonial positiva é válido, mas não pode prevalecer de forma absoluta. Assim, por exemplo, eventuais prejuízos devem ser compensados, integralmente, em exercícios futuros, a fim de preservar a capacidade contributiva, evitando a imposição sobre contribuintes que não apresentaram acréscimo patrimonial em dado período. ${ }^{170}$

\section{II.2.2.3 Indução por normas tributárias}

As normas tributárias indutoras serão alvo de análise mais detida no capítulo III. Por ora, cabe indicar a inadequação do critério da capacidade contributiva para aferição de igualdade quando o sistema tributário opera em sua faceta não arrecadadora ou extrafiscal.

Segundo Humberto Ávila, “a tributação obedece a limites decorrentes do princípio da igualdade segundo a capacidade contributiva, caso tenha por finalidade prevalente a obtenção de receita dos particulares, ou decorrentes do postulado da proporcionalidade, na hipótese de finalidade preponderantemente extrafiscal." 171

A grande questão quanto aos incentivos fiscais está na divisão de opiniões que promove. Mitigar a capacidade contributiva, enquanto corolário do princípio da igualdade, fundamental na busca pela concreção da justiça, deve exigir, no mínimo, rigoroso controle e transparência.

A atuação política dificulta, neste ponto com extrema severidade, uma definição clara, nítida do que seria justificável enquanto violação da capacidade contributiva. $\mathrm{O}$ Tribunal Constitucional Federal Alemão decidiu pela razão objetiva, por meio da qual o legislador justificaria a indução por meio do crescimento econômico e da geração de empregos. O bem comum também já foi evocado como justificativa, embora não possa haver uma definição universal sobre o que isso signifique. ${ }^{172}$ Certo está que a maximização do critério indutor e da capacidade contributiva deverá exigir, nesses casos, a aplicação do exame de proporcionalidade. ${ }^{173}$

\footnotetext{
${ }^{170}$ Cf. H. B. Ávila, Conceito de renda e compensação de prejuízos fiscais, p. 76.

${ }^{171}$ Cf. H. Ávila, Conceito de renda e compensação de prejuízos fiscais, p. 31. Remete-se o leitor ao item II.2.1.2 supra, onde foram tecidos maiores comentários acerca da proporcionalidade, inclusive como delimitadora das práticas indutoras nocivas e injustas.

${ }^{172}$ Cf. K. Tipke, Justiça fiscal e princípio da capacidade contributiva, pp. 40-41.

${ }^{173}$ Independente da escolha do critério para normas extrafiscais, sua legitimidade depende da observância do controle sob a ordem financeira ditada pela Constituição Federal. Não basta, entretanto, o controle formal. A juridicidade da medida indutora dependerá de sua conformação material ao que se propõe. Assim, não basta preencher demonstrativos ou acompanhar índices para cumprir as exigências da Lei de Responsabilidade
} 
Importa confrontar se o número de empregos criados ou se o avanço tecnológico gerado ou mesmo as desigualdades reduzidas se deveram, efetivamente, aos incentivos ofertados à fábrica vinda do exterior. Sob outro enfoque, interessa à sociedade saber e conhecer se esses resultados foram promovidos a custos menores aos cofres públicos do que a renúncia de receita praticada em benefício só daquele empresário migrante. Como ainda não se conseguiu implantar o controle material dos resultados dos incentivos, impõese saber se é ou não desejável manter a prática sob o risco da antijuridicidade.

Tipke parece já ter dado o caminho para a resposta ao sustentar que puro enfatismo econômico, ou seja, a sobrevalorização do efeito econômico dos impostos em detrimento da tributação isonômica conforme a capacidade contributiva, seria aceitável caso provesse um nível de vida inalcançável por meio da tributação justa. Como não se conseguiu provar a nocividade da justiça fiscal à eficiência econômica, ao Estado de Direito não resta alternativa senão priorizar a justiça em face da economia. ${ }^{174}$

\section{II.2.2.4 Razoabilidade e Coerência}

Variadas são as formas de atuação da razoabilidade, que estrutura a aplicação de outros princípios e regras. ${ }^{175}$ Diversa de outros deveres de medida como a igualdade e a proporcionalidade, a razoabilidade não cuida de uma relação entre meio e fim, mas do exame concreto-individual dos bens jurídicos envolvidos em determinado caso. ${ }^{176}$

A razoabilidade pode ser utilizada em vários contextos com fins diversos, devendose ressaltar sua atuação sob os espectros da equidade (entre normas gerias e a situação individual no caso concreto); congruência (entre normas gerais e a realidade a que visam regular, pois somente é possível regrar condutas possíveis); equivalência (relação que deve haver entre duas grandezas, como critério e medida); e coerência (veda validade de norma contraditória ou sem sentido prático). ${ }^{177}$

Fiscal ou das Leis Orçamentárias. Interessa, isso sim, criar mecanismos de medição dos resultados objetivamente alcançados pelas razões objetivas escolhidas pelo legislador. Em todo o caso, analisar normas tributárias indutoras sob os limites da ordem financeira é tema de alta relevância que merece estudo acurado. Por ora, restringimo-nos à mera indicação para outro trabalho, uma vez que o assunto está além do escopo desta tese.

${ }^{174}$ Cf. K. Tipke, Justiça fiscal e princípio da capacidade contributiva, p. 45.

${ }^{175}$ Cf. H. B. Ávila, Teoria dos princípios, p. 153.

${ }^{176}$ Cf. H. B. Ávila, Conceito de renda e compensação de prejuízos fiscais, p. 30.

${ }^{177}$ Cf. H. B. Ávila, Teoria dos princípios, p. 154-160. 
A razoabilidade como coerência será a diretriz geral em que as demais balizas do ordenamento deverão se enquadrar, a fim de permitir uma análise do sistema da tributação da renda a serviço da competitividade internacional do Brasil. Isso porque, em busca de maior inserção, o País pode editar normas impositivas ou indutoras. No primeiro caso, o critério diferenciador dos contribuintes será a capacidade contributiva; no segundo, diversos critérios podem justificar a norma indutora, os quais podem ser resumidos como estímulo ao desenvolvimento (fomento à pesquisa e ao desenvolvimento tecnológico, aumento do bem-estar social, redução de desigualdades regionais etc.). Certo é, contudo, que a legitimidade da indução dependerá do exame da proporcionalidade, a fim de verificar a relação entre a mitigação da capacidade contributiva e a valorização de um critério indutor.

Sob a lente da coerência, a razoabilidade exige relação de harmonia entre as normas e os elementos de fato e de direito que as compõem. Não há falar em normas que ensejam deveres antagônicos ou inexeqüíveis. ${ }^{178}$ Nesses casos, segundo Humberto Ávila, “cabe a verificação da constitucionalidade da norma diante das peculiaridades de um caso concreto, amparada pelo postulado da razoabilidade", ${ }^{179}$ já que ele será o responsável pela análise da coerência da imposição ou da renúncia praticada pelo legislador.

\section{II.2.2.5 Outros princípios constitucionais relevantes para a tributação da renda}

Há diversos princípios implícitos ou expressos na Constituição Federal que assumem condição relevante para a tributação da renda. Não se pretende, aqui, empreender análise pormenorizada sobre todos eles, já que o objetivo do presente capítulo requer sejam conhecidas balizas à concorrência tributária. Nesta esteira, busca-se compreender o porquê de haver tratamento dessemelhante para contribuintes em condições equivalentes quanto à capacidade contributiva. Por esta razão, a igualdade é o princípio que toma a vanguarda desta análise, avaliando-se justificativa, em face de diversos parâmetros coexistentes, para a concessão específica de incentivos fiscais a um determinado investidor.

Todavia, no capitulo IV serão empreendidas análises sobre específicos institutos do imposto de renda, submetendo-os às ordens tributária e econômica constitucionalmente

\footnotetext{
${ }^{178}$ Cf. H. B. Ávila, Conceito de renda e compensação de prejuízos fiscais. São Paulo: Malheiros Editores, 2011 , p. 30.

${ }^{179}$ Cf. H. B. Ávila, Conceito de renda e compensação de prejuízos fiscais. São Paulo: Malheiros Editores, 2011, p. 31.
} 
previstas. Assim, cumpre dar destaque, ainda que breve, a outros princípios relevantes para a tributação da renda.

Importa, pois, destacar a legalidade. Expressa no art. 150, I, CF, representa um dos pontos mais nobres do Estado de Direito. Dela decorre o princípio da reserva de lei, regulado pelo CTN, em seu artigo 97, segundo o qual somente lei formal poderá aumentar ou exigir tributo. Em matéria de imposto de renda, como se verá no capítulo IV, torna-se relevante pela abertura e indeterminação do conceito de renda, a fim de evitar que se tribute algo que a lei não defina como renda a título do referido imposto.

Uma das idéias fundamentais do direito, a segurança jurídica é sinônimo da própria paz social. Ricardo Lobo Torres afirma que este princípio retomou sua importância no momento em que a justiça também o fez, já que perdeu espaço na primeira metade do século XX. Assim, tem grande importância no ambiente capitalista e liberal, ${ }^{180}$ em que investidores precisam aferir a confiabilidade de um sistema tributário, calculando suas taxas de retorno com a máxima certeza possível. Não se aparta da legalidade e opõe-se ao arbítrio como medida da atuação estatal.

Especialmente no âmbito do direito tributário internacional, é corrente a idéia de que o tributo deveria influenciar o mínimo possível na alocação do capital. Essa máxima revela uma neutralidade intimamente ligada à eficiência. Ocorre que a própria imposição já é bastante para causar mudança no comportamento do contribuinte. Por crer no tributo como um dos fatores considerados para a decisão do investidor, opta-se por outro aspecto da neutralidade, aquele ligado à livre-concorrência como concretizadora da ordem econômica.

Neste sentido, o tributo deve impor-se a todos de forma equânime, impedindo que determinado agente econômico se sobreponha aos demais por vantagens decorrentes de ausência ou redução de tributação. Destarte, o legislador estaria balizado pelo princípio da livre concorrência, o que lhe exige atuação que não prejudique a igualdade de condições competitivas que se espera do mercado em um Estado de Direito. Trata-se, pois, da neutralidade concorrencial ${ }^{181}$ ou princípio da neutralidade econômica dos tributos. ${ }^{182}$

\footnotetext{
${ }^{180}$ Cf. R. L. Torres, Tratado de direito constitucional financeiro e tributário, v. III, pp. 168-171.

${ }^{181}$ Cf. L.E.Schoueri, Direito tributário, p.332.

${ }^{182}$ SCAFF, Fernando Facury. Efeitos da coisa julgada em matéria tributária e livre concorrência. In: Revista de Direito Público da Economia - RDPE, ano 4, n. 13, Belo Horizonte: Editora Fórum, 2006, p. 149. O autor ressalta a estreita relação entre neutralidade econômica dos tributos e o princípio da igualdade, que veda o tratamento desigual entre contribuintes em situação equivalente, o que inclui o exercício da livre concorrência. Para Scaff, em suma, a neutralidade concorrencial é um dos requisitos para o exercício da livre concorrência, cuja base primordial está no princípio da igualdade.
} 
II.2.3 Fiscalidade e indução sob a Ordem Econômica

II.2.3.1 Limitações da Ordem Econômica às normas tributárias indutoras no plano doméstico

A ordem econômica foi alvo de especial atenção do constituinte. Tem-se ordem como o resultado da coerência entre seus elementos integrantes, de modo que, expressos ou implícitos, seja possível identificar seus efeitos sobre o mundo real. Assim, a Constituição Econômica, no dizer de Eros Grau, compreenderia o "conjunto de preceitos que institui determinada ordem econômica (mundo do ser), o conjunto de princípios e regras essenciais ordenadoras da economia." Dela se espera que consagre determinado sistema econômico. ${ }^{183}$

Sabendo-se que o tributo jamais é neutro, pois sempre produzirá efeitos que sem ele não ocorreriam na economia, interessa avaliar as balizas em que a norma tributária pode induzir comportamentos de agentes econômicos com segurança e harmonia perante a ordem econômica nacional e internacional. Por ora, será avaliada a primeira dessas relações, restando à segunda o item subseqüente.

Nossa Constituição, rica de princípios econômicos, impõe ao hermeneuta interpretação que, embora não se possa tomar como absoluta, ${ }^{184}$ deve impor diretriz de segurança sobre os agentes econômicos. É o que Schoueri denomina "vetor da atuação estatal positiva", que grafa o dever de valorizar a pessoa humana, garantindo-lhe existência digna em um ambiente socialmente justo. ${ }^{185}$

Mas essa resultante não advém de poucos vetores. Com efeito, a ordem econômica grafada na Constituição Federal não cabe no espaço geográfico que lhe foi destinado, abraçando princípios expressos em outros campos, como até mesmo outros implícitos, dos quais não se pode prescindir. ${ }^{186}$ Daí a afirmação de Grau: "Não se interpreta a Constituição

\footnotetext{
${ }^{183}$ GRAU, Eros Roberto. A ordem econômica na Constituição de 1988 -interpretação e crítica. 8.ed. São Paulo: Malheiros editores, 2003, p. 70. O autor recorre à lição de Max Weber, que dissocia a ordem jurídica (ideal do dever-ser) da ordem econômica (mundo dos acontecimentos reais), para ilustrar que mesmo assim a última seria uma parcela da primeira, que compreenderia, vista como sistema de princípios e regras, as ordens pública, privada, econômica e social. V. GRAU, Eros Roberto. A ordem econômica na Constituição de 1988 -interpretação e crítica. 8.ed. São Paulo: Malheiros editores, 2003, p. 49 e p. 70.

${ }^{184}$ Cf. E. Grau, A ordem econômica na Constituição de 1988 -interpretação e crítica, p. 143.

${ }^{185}$ Cf. L.E. Schoueri, Normas tributária indutoras, p. 83.

${ }^{186}$ Cf. E. Grau, A ordem econômica na Constituição de 1988 -interpretação e crítica, p. 136. Para o autor, o direito é um sistema composto por: (i) princípios explícitos: grafados no texto constitucional; (ii) princípios implícitos: resultam da análise de um ou mais preceitos constitucionais ou de uma lei ou conjunto de textos normativos infraconstitucionais; e (iii) princípios gerais de direito: também implícitos, mas coletados do direito pressuposto ( e não positivado) .
} 
em tiras, aos pedaços." No dizer de Barroso seria a filtragem constitucional, expressão da superioridade não apenas formal, mas, sobretudo, material e axiológica sobre todos os ramos do direito, impondo-se, destarte, sobre a ordem econômica. ${ }^{187}$

Logo, o plano global normativo imposto pela Constituição em seu caráter dirigente, ${ }^{188}$ encontra-se, topograficamente no Título VII - Da Ordem Econômica e Financeira, logo a seguir, e não por acaso, ao Título VI- Da Tributação e do Orçamento. A lógica espacial da Carta Política vai ai encontro da dupla atribuição de predicados que se dá à norma sob exame (diádica): em primeiro lugar, tributária - sujeita à ordem tributária; e, em segundo, indutora - adentrando ao espaço econômico não como figurante, mas atora capaz de auxiliar na concretização dos programas, diretrizes $e$ fins visados pela Constituição Econômica. ${ }^{189}$

Nesta esteira, haveria relação estreita entre tributação e ordem econômica, influindo uma na outra, de modo que a justificação da primeira não pode repousar, exclusivamente, na doutrina tributária, devendo observar coerência com ambas as ordens. ${ }^{190}$ Devem, pois, as normas tributárias indutoras conformar-se aos princípios constitucionais ligados às ordens tributária e econômica. ${ }^{191}$

A atuação do legislador, não podendo ser neutra por imposição constitucional, deve projetar-se sobre a ordem econômica e social, modificando-a de acordo com os demais imperativos constitucionais, a fim de promover equilíbrio e organização de recursos para o atingimento do desenvolvimento econômico e humano. Assim, normas tributárias indutoras representam instrumento disponível cujos efeitos devem estar sujeitos aos limites impostos pela justiça tributária, assim entendida como verdadeira justiça estruturante. $\mathrm{O}$ alcance desta estaria além dos efeitos de repartição justa da carga estatal como na justiça distributiva, já que, de forma prospectiva, trabalha para modificar a própria estrutura social de forma planejada. ${ }^{192}$

\footnotetext{
${ }^{187}$ BARROSO, Luís Roberto. Interpretação e aplicação da Constituição - Fundamentos de uma dogmática constitucional transformadora. 6. ed. São Paulo: Saraiva, 2004. p. 339-340.

${ }^{188}$ A Constituição pode ser classificada como estatutária -ou orgânicas - definem um estatuto de poder, seja da propriedade dos meios de produção, dos agentes econômicos, do trabalho, da coordenação da economia, das organizações do capital e do trabalho. Apenas afirmam normas que retratem a ordem econômica; e as diretivas ou programáticas - não são meros instrumentos de governo, mas enunciadoras de diretrizes, programas e fins a serem realizados pelo estado e pela sociedade. Elas definem o quadro de diretrizes das políticas públicas, mas sempre guardando coerência com os objetivos anunciados pela própria Constituição. Cf. E. Grau, A ordem econômica na Constituição de 1988 -interpretação e crítica, pp. 66-67.

${ }_{189}$ Cf. E. Grau, A ordem econômica na Constituição de 1988 -interpretação e crítica, pp.66-67.

${ }^{190}$ Cf. L.E. Schoueri, Normas tributária indutoras, p. 87.

${ }^{191}$ Cf. L.E. Schoueri, Normas tributária indutoras, p. 89.

192 Schoueri evoca a lição de Klaus Vogel ("Steuergerechtigkeit und soziale Gestaltung", Deutsche Steuerzeitung, out. 1975, pp. 409 a 415) para redimensionar a justiça tributária, conferindo-lhe o caráter de
} 
A conformação da ordem econômica à justiça social, exigida pelo art. 170, CF, permite ao legislador a escolha de critérios outros que não a capacidade contributiva como modo de medir igualdade e promover justiça. Assim, é possível, em respeito ao princípio da livre concorrência (art. 170, IV, CF) ou da preservação do meio ambiente (art. 170, VI, $\mathrm{CF}$ ), ambos fatores consagrados pela ordem econômica, haver diferença no tratamento tributário conferido a contribuintes com idêntica capacidade contributiva. ${ }^{193}$

A utilidade dessas análises diz, basicamente, que a justiça social, a qual deve se conformar a ordem econômica, ganha magnitude maior, interagindo com outras qualificações da justiça, para buscar, em último grau, a concretização da solidariedade que deve significar repartição de riquezas, bem-estar, dignidade humana e ambiente seguro. Para a consecução desses objetivos, dentro do que se pretende analisar, devem ser evocadas justiça tributária e justiça orçamentária, não apenas para garantir a solidariedade na arrecadação, mas no dispêndio e, sobretudo, na renúncia da receita. ${ }^{194}$ Dá suporte a esta conclusão a posição de Eros Grau, ao assertar que está superada a “injustificada alusão do texto constitucional, a uma ordem econômica e a uma ordem social.”195

Como já mencionado, a ordem econômica não se encontra adstrita ao Título VII da $\mathrm{CF}$, valendo-se de outros preceitos, dentre os quais os grafados nos princípios fundamentais (arts. $1^{\circ}$ e $3^{\circ}$ ); direitos individuais e coletivos (art. $5^{\circ}$ LXXI); direito sociais (arts. $7^{\circ}$ a 11); tributação e orçamento (art. 149); ordem social, especialmente, previdência social (arts. 201 e 202), ciência e tecnologia (arts. 218 e 219) e meio ambiente (art. 225). ${ }^{196}$

O constituinte, no caput do art. 170, alicerçou a ordem econômica sobre valorização do trabalho e livre iniciativa, mandamentos para o Estado atuar na promoção plena da dignidade da pessoa humana. ${ }^{197}$ A despeito de a conformação da norma tributária indutora à ordem jurídica depender de análise mais complexa, ponderando-se outros

modificação planejada do futuro em vista das alterações promovidas no quadro sócio-econômico pela atuação medida, pensada, por parte do legislador. Cf. L.E.Schoueri, Normas tributárias indutoras, p. 3.

193 Cf. L.E. Schoueri, Direito tributário, p. 315.

${ }^{194}$ Enquanto a justiça tributária está bem assentada em arcabouço constitucional consagrado por princípios limitadores do poder de tributar do Estado, a justiça orçamentária tem alcance mais amplo; afinal o orçamento engloba todas as receitas públicas, dentre as quais os ingressos tributários, assim como as despesas públicas. Conclui-se, destarte, que a justiça orçamentária preconiza a própria justiça tributária, impregnando-a dos ideais sociais e econômicos, mas estendendo-os, também, aos gastos públicos, de modo que seu potencial de valoração da justiça é dobrado. Na expressão feliz de Ricardo Lobo Torres, "a justiça orçamentária não tem um fim em si mesma, senão que serve de veículo para alcançar a justiça política, social e econômica. Cf. R.L.Torres, Tratado de direito constitucional financeiro e tributário, volume III, p. 122.

${ }^{195}$ Cf. E. Grau, A ordem econômica na Constituição de 1988 -interpretação e crítica, p.155.

${ }^{196}$ Cf. E. Grau, A ordem econômica na Constituição de 1988 -interpretação e crítica, p.155.

${ }^{197}$ Cf. L.E. Schoueri, Normas tributária indutoras, p. 86. 
valores, ora implícitos, ora constantes da ordem tributária, pode-se realizar um primeiro juízo de conformação à ordem econômica, tomando-se o referido artigo constitucional.

Destarte, a soberania nacional (art. 170, I) aqui pode ser entendida em uma de suas dimensões: a soberania econômica. A CF regra sobre a inserção brasileira na ordem internacional, optando por uma posição integrativa, expressa no art. $4^{\text {o }}$, parágrafo único. ${ }^{198}$ Deve o País pautar sua ação no sentido de seu crescimento econômico, sempre balizado pelos fins de existência digna e justiça social, buscando reduzir a dependência do estrangeiro, apesar das dificuldades em tempos de globalização. Ilustração de efeito traz Fabio Nusdeo, ao evocar as metáforas de Finzi - para quem as normas instrumentais de política econômica seriam como um "corte transversal na árvore do Direito", marcando com suas peculiaridades seus diversos ramos-, e de Jeantet, que se vale da imagem das correntes marítimas nos oceanos. ${ }^{199}$ Em ambos os casos, o que se deseja expressar é um direito intromissor, sobrepondo-se a outros ramos jurídicos de forma que dessa interação resulte a concreção dos programas e diretrizes determinados em face da soberania econômica. Assim, estarão ajustados aos objetivos de soberania econômica os incentivos fiscais que desenvolvam a qualidade da mão-de-obra, elevando o nível do ensino; estimulem investimentos em tecnologia, pesquisa e desenvolvimento; ou que, em geral, facultem ao País a alocação melhor de seus fatores de produção. ${ }^{200}$

Na mesma esteira, a livre-concorrência (art. 170, IV) está assegurada não como fim em si mesmo, mas como meio de garantir a justiça social em ambiente de respeito e valorização da pessoa humana. A livre concorrência reprime o abuso do poder econômico que vise à dominação dos mercados, ${ }^{201}$ e à eliminação da concorrência (art. 173, $\left.\S^{\circ}\right){ }^{202}$

O princípio da livre-concorrência atua corrigindo falhas de mercado, ${ }^{203}$ sendo que por meio das normas tributárias indutoras, usualmente, se traduz pela mitigação da legalidade, autorizando a mudança de alíquotas do II, IE, IPI e IOF. Atua também obstando

\footnotetext{
${ }^{198} \mathrm{CF}$, art. $4^{\text {o }}$, parágrafo único. A República Federativa do Brasil buscará a integração econômica, política, social e cultural dos povos da América Latina, visando à formação de uma comunidade latino-americana de nações.

${ }^{199}$ Cf. F. Nusdeo, Curso de Economia: introdução ao direito econômico, pp.205-206.

${ }^{200}$ Cf. L.E. Schoueri, Normas tributária indutoras, p. 90.

201 A livre-concorrência atua para a preservação do mercado. Este se reveste da natureza de patrimônio nacional a ser incentivado a viabilizar o desenvolvimento socioeconômico e cultural, o bem-estar e a autonomia tecnológica do País (art. 219, CF).

${ }^{202}$ Cf. F.F. Scaff, Efeitos da coisa julgada em matéria tributária e livre concorrência, p. 146.

203 As falhas de mercado seriam: (a) quanto à mobilidade de fatores: falha de origem física ou cultural ; (b) quanto ao acesso à informação: falha de origem legal; (c) quanto à concentração econômica: falha de estrutura; (d) quanto às externalidades: falha de sinal; e (e) quanto ao suprimento de bens coletivos: falha de sinal decorrente de falha de incentivos. Cf. F. Nusdeo, Curso de Economia: introdução ao direito econômico, p.166.
} 
a anterioridade com relação aos mesmos impostos e, quando no caso da anterioridade mínima do art., 150 , III, c, do IR em vez do IPI. ${ }^{204}$

Há diversas formas de atuação para preservação da concorrência em função das falhas de mercado, mas no que tange à concessão de incentivos fiscais para o IED, interessa conhecer de sua conformação às diretrizes e programas preconizados pela Constituição Econômica, para evitar vantagem discriminatória ao empresário residente ou ao investidor não-residente. ${ }^{205}$ Ganha importância, neste aspecto, a neutralidade concorrencial, uma vez que a oferta de incentivos como isenção do imposto por prazo determinado ou depreciação acelerada, por exemplo, não deverá resultar em quebra da igualdade de condições de competir no mercado aberto. ${ }^{206}$

Poderá, igualmente, o legislador decidir pela renúncia de receitas para promover a redução das desigualdades regionais e setoriais. Neste caso, o legislador opera em conformação com a justiça social, em seu mister de redistribuir riquezas para reduzir desigualdades e proteger os menos favorecidos. Trata-se de princípio econômico decorrente da solidariedade que assume caráter de relevância e urgência, pois o País é um dos mais iníquos no que toca à distribuição de renda.

A busca do pleno emprego exige que a norma tributária indutora incentive atividades geradoras de emprego em detrimento de especulativas, o que lhe aproxima da valorização do trabalho humano. ${ }^{207}$

O livre exercício de qualquer atividade econômica é, ainda, um limite às normas tributárias indutoras, que não poderão resultar em dificuldades a determinada atividade empresarial. Em suma, os estímulos propostos pela via tributária não podem discriminar qualquer forma de atuação profissional sob pena de inconstitucionalidade. ${ }^{208}$

Em resumo, os princípios da ordem econômica poderão representar balizas à atuação do legislador que editar normas tributárias indutoras. A constitucionalidade dessas normas dependerá de análise casuística em que sejam consideradas as finalidades próprias da intervenção econômica.

\footnotetext{
${ }^{204}$ Cf. L.E. Schoueri, Direito tributário, p.332.

${ }^{205}$ O Brasil avançou no tema da dominância de mercado com a edição da Lei 8.884/94, em vista da formação do Sistema Brasileiro de Defesa da Concorrência, composto pela Secretaria de Direito Econômico, Secretaria de Acompanhamento Econômico e pelo Conselho Administrativo de Defesa Econômica-CADE.

${ }^{206}$ Cf. F.F. Scaff. Efeitos da coisa julgada em matéria tributária e livre concorrência, p. 149. No mesmo sentido, L.E. Schoueri, Direito tributário, p.333.

${ }^{207}$ Cf. L.E. Schoueri, Normas tributária indutoras, p. 107.

${ }^{208}$ Cf. L.E. Schoueri, Direito tributário, p. 351.
} 
II.2.3.2 Limitações da Ordem Econômica às normas tributárias indutoras no plano internacional

As normas tributárias indutoras, inclusive referentes ao imposto de renda, podem sofrer restrições no âmbito internacional, especialmente em virtude da regulação do direito econômico pela Organização Mundial de Comércio- OMC. Esta organização internacional, após a decisão de seu Órgão de Solução de Controvérsias-OSC no caso das norteamericanas Foreign Sales Corporations $-F S C,{ }^{209}$ despertou as atenções para a compatibilização internacional entre comércio e tributação. A pedra-de-toque dessa relação são as subvenções diretas ou fiscais, que podem configurar subsídios na normatização da OMC. Daí Yariv Brauner categoricamente afirmar que "Em nenhuma outra área o conflito entre os regimes de comércio e tributário internacionais é tão aparente quanto na seara dos subsídios tributários às exportações." 210

A OMC é resultado das aspirações da Conferência de Breton Woods - 1944, mesma célula mater do Banco Mundial -BIRD, Fundo Monetário Internacional -FMI e da Organização Internacional do Comércio -OIC. Esta última, no entanto, não chegou a ser criada, uma vez que a Carta de Havana, que lhe fixava as diretrizes, jamais foi ratificada pelo Congresso dos EUA. Resolveu-se, então, adotar apenas a Política Comercial da referida Carta, que passou a se denominar Acordo Geral sobre Tarifas e Comércio -GATT 1947 (antigo GATT). ${ }^{211}$

O GATT jamais foi, juridicamente, uma organização internacional, mas um tratado intergovernamental. Não possuía membros, mas signatários que costuraram o sistema de comércio mundial ao longo de oito rodadas de negociações multilaterais. ${ }^{212}$ De fato, com a Rodada Uruguai (1986-1994), foi estabelecida a OMC, organização internacional capaz de

\footnotetext{
${ }^{209}$ Caso US - FSC (DS 108), encerrado em 2006.

${ }^{210}$ BRAUNER, Yariv. Direito do comércio internacional e acordos tributários. In: COSTA, Alcides Jorge; SCHOUERI, Luís Eduardo e BONILHA, Paulo Celso Bergstrom (coord.), Direito Tributário Atual 23. São Paulo: Dialética, 2009. p. 21.

${ }^{211}$ A Carta de Havana de 1948 tinha por objetivo a criação da OIC, por meio da qual o comércio internacional passaria a ser visto não de forma isolada, mas como integrante de um contexto maior. Em sua negociação, foram abordados temas como atividade econômica, desenvolvimento econômico, práticas comerciais restritivas, acordos sobre commodities, investimento e padrões trabalhistas. Na verdade, a Carta de Havana não foi ratificada pelo Congresso dos EUA e, conseqüentemente, a OIC não foi criada. Cf. Vera Thorstensen,OMC: as regras do comércio internacional e a nova rodada de negociações multilaterais, $\mathrm{p}$. 306. O antigo GATT foi um conjunto de normas e instituições. Já o GATT de 1994, como acordo sob a égide da OMC, nada mais é do que um conjunto de normas. Cf. HOEKMAN, Bernard; KOSTECKI, Michel. The political economy of the world trading system. 2. ed. Oxford University Press, 2001, p.37.

${ }^{212}$ Rodadas Genebra (1947), Annecy (1949), Torquay (1951), Genebra (1956), Dillon (1960-1961), Kennedy (1964-1967), Tóquio (1973-1979) e Uruguai (1986-1994). Cf. Vera Thorstensen,OMC: as regras do comércio internacional e a nova rodada de negociações multilaterais, p. 31.
} 
administrar acordos multilaterais sobre o comércio de bens (GATT 1994); ${ }^{213}$ serviços (GATS) e de aspectos relacionados à propriedade intelectual (TRIPS). ${ }^{214}$

A OMC é a principal fonte do direito econômico internacional e seu objetivo central é o livre comércio, de modo que sua normatização está voltada para a redução ou eliminação de barreiras comerciais. Em geral, tais normas não alteram ou lidam diretamente com ordem interna, mas procuram uniformização de procedimentos a serem observados pelos Estados. ${ }^{215}$

A atuação da OMC contra o protecionismo está alicerçada em princípios, dos quais destacam-se :

(i) Nação Mais Favorecida: art. I do GATT; ${ }^{216}$ art. II do GATS e art. IV do TRIPs. Deve-se tratar igualmente todos os membros da OMC, de modo que eventual tratamento conferido a um determinado membro seja estendido aos demais. É corolário do princípio da não discriminação.

(ii) Tratamento Nacional: art. III do GATT, ${ }^{217}$ art. XVII do GATS e art. III do TRIPS. Produtos, serviços ou marcas importadas devem receber o mesmo tratamento dos

${ }^{213}$ Além do Acordo Geral sobre Tarifas e Comércio, há doze outros acordos multilaterais sobre o comércio de bens: acordo sobre agricultura, aplicação de medidas sanitárias e fitossanitárias, têxteis e confecções, barreiras técnicas ao comércio, medidas de investimento relacionadas ao comércio, antidumping, valoração aduaneira, inspeção pré-embarque, regras de origem, licenças de importação, subsídios e medidas compensatórias e salvaguardas. Cf. Vera Thorstensen,OMC: as regras do comércio internacional e a nova rodada de negociações multilaterais, p.42.

${ }^{214} \mathrm{Cf}$. B. Hoekman e M. Kostecki, The political economy of the world trading system, p.37.

${ }^{215} \mathrm{Cf}$. Y. Brauner, Direito do comércio internacional e acordos tributários, p.13.

${ }^{216}$ GATT. ARTIGO I. TRATAMENTO GERAL DE NAÇÃO MAIS FAVORECIDA 1. Qualquer vantagem, favor, imunidade ou privilégio concedido por uma parte contratante em relação a um produto originário de ou destinado a qualquer outro país, será imediata e incondicionalmente estendido ao produtor similar, originário do território de cada uma das outras partes contratantes ou ao mesmo destinado, Êste dispositivo se refere aos direitos aduaneiros e encargos de tôda a natureza que gravem a importação ou a exportação, ou a elas se relacionem, aos que recaiam sôbre as transferências internacionais de fundos para pagamento de importações e exportações, digam respeito ao método de arrecadação dêsses direitos e encargos ou ao conjunto de regulamentos ou formalidades estabelecidos em conexão com a importação e exportação bem como aos assuntos incluídos nos $\S \S 1$ e 2 do art. III.

${ }^{217}$ GATT. ARTIGO III. TRATAMENTO NACIONAL EM MATÉRIA DE IMPOSTOS E DE REGULAMENTAÇÃO INTERNOS

1. Os produtos de qualquer Parte Contratante importados no território de outra Parte Contratante serão isentos da parte dos tributos e outras imposições internas de qualquer natureza que excedam aos aplicados, direta ou indiretamente, a produtos similares de origem nacional. Além disto, nos casos em que não houver no território importador produção substancial de produto similar de origem nacional, nenhuma Parte Contratante aplicará tributos internos novos ou mais elevados sôbre os produtos de outras Partes Contratantes com o fim de conceder proteção à produção de produtos, diretamente competidores ou substitutos, não taxados de maneira semelhante; os tributos internos dessa natureza, existentes, serão objeto de negociação para a sua redução

ou eliminação. 2. Os produtos originários de qualquer Parte Contratante importados no território de qualquer outra Parte Contratante gozarão de tratamento não menos favorável que a concedido a produos similares de origem nacional no que concerne a todas as leis, regulamentos e exigências que afetem a sua venda, colocação no mercado, compra, transporte, distribuição ou uso no mercado interno. As disposições dêste parágrafo não 
nacionais após ingressarem no mercado doméstico. Também representa corolário do princípio da não discriminação.

(iii) Liberalização do Comércio: combate a tarifas e quotas, mas de forma progressiva, gradual, a fim de evitar distorções;

(iv) Transparência: exige clareza e divulgação da normatização interna quando dispuser sobre medidas econômicas de repercussão internacional, especialmente quanto a normas tributárias indutoras;

(v) Competição justa: os Estados devem procurar a inserção internacional de forma convergente às determinações da OMC, em conformidade com os acordos específicos de cada área de atuação.

Dentre os acordos multilaterais sobre comércio de bens, convém estremar o Acordo sobre Subsídios e Medidas Compensatórias - ASMC, por ter debelado a insegurança reinante no comércio internacional ao definir subsídios, em seu artigo I. ${ }^{218}$ Em síntese, a constatação da existência de um subsídio dependerá, cumulativamente, de haver um benefício específico a uma empresa ou indústria determinada como resultado de uma contribuição financeira de um governo. ${ }^{219}$

Um benefício ou vantagem específica a uma empresa ou indústria é aquele resultante da comparação entre a situação da empresa após receber o auxílio público e sem

impedirão a aplicação das taxas diferenciais de transportes, baseadas exclusivamente na utilização econômica dos meios de transporte e não na origem de produtos.

${ }^{218}$ ACORDO SOBRE SUBSÍDIOS E MEDIDAS COMPENSATÓRIAS. Definição de subsídio

1. Para os fins deste Acordo, considerar-se-á a ocorrência de subsídio quando:

(a) (1) haja contribuição financeira por um governo ou órgão público no interior do território de um Membro (denominado a partir daqui "governo"), i.e.:

(i) quando a prática do governo implique transferência direta de fundos (por exemplo, doações, empréstimos e aportes de capital), potenciais transferências diretas de fundos ou obrigações (por exemplo garantias de empréstimos);

(ii) quando receitas públicas devidas são perdoadas ou deixam de ser recolhidas (por exemplo, incentivos fiscais tais como bonificações fiscais) ${ }^{1}$;

(iii) quando o governo forneça bens ou serviços além daqueles destinados a infra-estrutura geral ou quando adquire bens;

(iv) quando o Governo faça pagamentos a um sistema de fundos ou confie ou instrua órgão privado a realizar uma ou mais das funções descritas nos incisos (i) a (iii) acima, as quais seriam normalmente incumbência do Governo e cuja prática não difira de nenhum modo significativo da prática habitualmente seguida pelos governos; ou

(a) (2) haja qualquer forma de receita ou sustentação de preços no sentido do Artigo XVI do GATT 1994; e

(b) com isso se confira uma vantagem.

2. Um subsídio, tal como definido no parágrafo 1, apenas estará sujeito às disposições da PARTE II ou às disposições das PARTES III ou V se o mesmo for específico, de acordo com as disposições do Artigo 2.

Cf. texto extraído da página do Ministério do Desenvolvimento, Indústria e Comércio Exterior, http://www.mdic.gov.br/arquivos/dwnl_1196686041.doc.

${ }^{219}$ Cf. Vera Thorstensen, OMC: as regras do comércio internacional e a nova rodada de negociações multilaterais, p.133. 
tal recebimento (but-for-test). Para evitar a especificidade da vantagem, a autoridade pública deverá estabelecer critérios objetivos ou condições de elegibilidade, com a máxima transparência e clareza, veiculados por lei, de forma a não limitar candidaturas para obtenção da vantagem. ${ }^{220}$

O Anexo I do ASMC traz uma lista ilustrativa de subsídios à exportação, onde se lê "Isenção, remissão ou diferimento, total ou parcial, concedido especificamente em função de exportações, de impostos diretos ou impostos sociais pagos ou pagáveis por empresas industriais ou comerciais."

Uma vez que, para os fins do ASMC, o termo "impostos diretos" significa impostos sobre salários, lucros, juros, rendas, direitos de autor e todas as outras formas de ganho, ${ }^{221}$ normas indutoras em matéria de tributação da renda podem configurar subsídios. $^{222}$

Duas são as espécies de subsídios segundo a classificação do ASMC: ${ }^{223}$

(ii) Subsídios amarelos ou acionáveis: exigem prova do dano sofrido pelo membro prejudicado, que poderá solicitar a abertura de um painel no âmbito do OSC para pacificar a questão, mas não na via do procedimento sumário. Em geral, três são os tipos de danos causados: à indústria doméstica do país importador; a exportadores rivais competindo por um terceiro mercado; e a exportadores competindo por um mercado onde vigoram subsídios domésticos.

(iii) Subsídios vermelhos ou proibidos: sujeitos a procedimento sumário no OSC da OMC, indicam quebra de ética na ordem econômica internacional e independem de dano.

Muitos foram os avanços conseguidos pelo GATT e pela OMC desde sua criação, pois desbravaram um ambiente altamente protecionista desde a primeira metade do século passado. A questão da quebra de barreiras passa por diversos tributos, especialmente os

\footnotetext{
${ }^{220}$ Cf. Vera Thorstensen,OMC: as regras do comércio internacional e a nova rodada de negociações multilaterais, p.134.

221 Esclarecimentos ao Anexo I do ASMC, Nota 58. Disponível em: http://www.mdic.gov.br/arquivos/dwnl_1196686041.doc. Acesso em 20 out 2011.

${ }^{222}$ Cf. L.E.Schoueri, Normas tributárias indutoras, p. 212.

${ }^{223}$ Uma terceira espécie de subsídios vigeu por cinco anos, até 31 de dezembro de 1999, subsídios verdes ou não-acionáveis. Basicamente, eram inespecíficos, ou seja, não se destinavam ao favorecimento individualizado de qualquer setor ou empresa. Havia, contudo, exceções, caso fossem concedidos para o setor de P\&D ou para reduzir desigualdades regionais ou locais, ou para a proteção do meio ambiente. Eram lícitos no contexto da OMC e, em razão disso, não estavam sujeitos a acionamento perante o OSC. Cf. ORGANIZAÇÃO MUNDIAL DO COMÉRCIO. Understanding the WTO: the agreements. Disponível em http://www.wto.org/english/thewto_e/whatis_e/tif_e/agrm8_e.htm\#subsidies. Acesso em 18 dez 2011.
} 
aduaneiros, mas atinge também o imposto de renda. Historicamente, porém, a tributação direta não esteve no centro das discussões internacionais sobre protecionismo.

Brauner reconhece, entretanto, a necessidade de alteração na ordem tributária internacional, haja vista a aplicação prática das normas OMC sobre tributação direta no caso FSC. $^{224}$ Haveria, por assim dizer, uma potencial indisposição entre as regras internacionais de comércio e de tributação, resultante das próprias finalidades de cada qual.

O tributo, quando usado para induzir comportamentos, ainda que instrumentalize uma política publica legítima sob o ponto de vista de um Estado, não poderá confrontar a ordem internacional. Esta, por sua vez, teria um alcance bem maior do que o aparentemente considerado pelos sujeitos e atores da ordem internacional. Em essência, a normatização da OMC seria potencialmente restritiva a dispositivos da legislação do imposto de renda adotados pelos Estados. ${ }^{225}$

Com efeito, a legislação do imposto de renda poderá significar protecionismo quando discriminar produtos importados em relação aos nacionais ou importados entre si ou, ainda, quando beneficiar especificamente um segmento empresarial ou empresa (subsídio). ${ }^{226}$

Tais evidências ganharam visibilidade após o caso FSC, que discutiu subsídios a exportações tornando-se a "mais importante intervenção da OMC na política doméstica de tributação da renda". ${ }^{227}$ Este caso teve início em 1976, quando os EUA foram contestados pela Comunidade Européia, por conta de suas regras DISC - Domestic International Sales Corporation - que conferiam diferimento sem prazo a uma parcela dos rendimentos de exportações de empresas DISC. Ainda perante o Conselho do GATT, as regras DISC foram tidas por contrárias ao art. XVI:4 do GATT. Em 1984, os EUA conformaram as regras DISC à opinião do Conselho, editando as regras FSC, que isentavam parcela da renda das exportações de fonte estrangeira.

O novo regime permitia a instalação de subsidiárias (Foreign Sales Corporations) em paraísos fiscais por onde deveriam ser escoadas as exportações de empresas norte-

\footnotetext{
${ }^{224}$ Cf. Y. Brauner, Direito do comércio internacional e acordos tributários, p.23.

225 Como exemplo de dispositivos da legislação do imposto de renda capazes de ofertar subvenções diretas podem ser apontados, dentre outros, depreciação acelerada para determinados setores ou empresas, deduções autorizadas somente para insumos nacionais, imposição mais baixa sobre fatores de produção em determinado segmento.

226 VETTORI, Gustavo Gonçalves. Contribuição ao estudo sobre as influências recíprocas entre a tributação da renda e o comércio internacional. Tese de doutorado - Faculdade de Direito da USP, São Paulo, 2011, p. 194. Ao concluir sua pesquisa, Vettori sustenta que os acordos GATT, TRIM, ASMC ligados a produtos e, ainda, o GATS, referente a serviços, aplicam-se a medidas protecionistas constantes da legislação do imposto de renda.

${ }^{227}$ Cf. Y. Brauner, Direito do comércio internacional e acordos tributários, p.29.
} 
americanas. Valendo-se de um permissivo na legislação de preços de transferência, ${ }^{228}$ parcela do lucro gerado pelas exportações era alocada na subsidiária FSC e excluída da sistemática de tributação universal vigente nos EUA. Os lucros alocados na FSC eram excluídos da tributação independente de distribuição. Se retidos, estavam ao abrigo das regras $\mathrm{CFC} ;{ }^{229}$ se distribuídos, a isenção alcançava os dividendos, de modo a não incidir tributação sobre a controladora americana. Para usufruir do benefício, os lucros deveriam ser tidos por foreign trade income da FSC, o que exigia fossem lucros decorrentes de venda no exterior de bens produzidos nos EUA que não tivessem mais de 50\% de seu valor de mercado atribuído a bens importados. ${ }^{230}$

Novamente contestados pela Comunidade Européia, os EUA receberam decisão final do Painel de solução de controvérsias da OMC em 2000, reconhecendo o regime FSC como subsídio às exportações contrário ao ASMC. Buscando conformação com a decisão do Painel, os EUA substituíram o regime FSC pelo ETI.

Basicamente, o regime ETI deveria produzir similares efeitos às regras FSC, inobstante os EUA o terem anunciado não como substituo das últimas, mas como efetiva reforma tributária para incorporar aspectos territoriais à sua sistemática de tributação universal. ${ }^{231}$ A UUEE dessa vez argüiu a incompatibilidade das regras ETI com a decisão do caso FSC, sobrevindo a decisão do OSC em 2002. Como o regime não foi revogado pelo Congresso dos EUA, a UUEE retaliou e o regime foi, finalmente, revogado em $1^{\circ} \mathrm{de}$ janeiro de $2005 .^{232}$

A solução do OSC no caso FSC não reprovou a sistemática de tributação universal adotada pelos EUA, mas a exclusão de alguns rendimentos obtidos no exterior que fora concedida para beneficiar exportadores norte-americanos se comparados a outros residentes em países que optaram pela tributação territorial. ${ }^{233}$ A lógica dos EUA estava na competitividade de seus exportadores, a quem se pretendia conferir o mesmo tratamento de concorrentes não tributados por rendimentos obtidos no exterior, em vista da tributação territorial adotada por seus Estados de residência.

\footnotetext{
${ }^{228}$ V. tópico IV.3.3.

${ }^{229}$ V. tópico IV.3.2.

${ }^{230}$ Cf. G.V. Vettori, Contribuição ao estudo sobre as influências recíprocas entre a tributação da renda e o comércio internacional, p. 132.

${ }^{231}$ Cf. G.V. Vettori, Contribuição ao estudo sobre as influências recíprocas entre a tributação da renda e o comércio internacional, p. 135.

${ }^{232}$ Cf. Y. Brauner, Direito do comércio internacional e acordos tributários, p.30.

${ }^{233}$ Gustavo Vettori noticia que "Os EUA não poderiam, (...) assim, justificar um subsídio à exportação como uma medida para eliminar uma desvantagem aos seus exportadores criada pelo seu próprio sistema.”Cf. G.V. Vettori, Contribuição ao estudo sobre as influências recíprocas entre a tributação da renda e o comércio internacional. Tese de doutorado - Faculdade de Direito da USP, São Paulo, 2011, p. 136.
} 
Ao qualificar o regime FSC por subsídio, o OSC partiu de um parâmetro normativo conforme a legislação dos EUA, não para interferir nas escolhas do País, mas para identificar desvios do sistema parâmetro, que se caracterizem por subsídios proibidos ou acionáveis. ${ }^{234}$ Contudo, grande dificuldade haveria em definir um parâmetro do imposto de renda para lhe identificar os desvios e, então, por conseqüência, os incentivos fiscais.

A questão da conciliação entre normas do imposto de renda e ordem econômica internacional ainda precisa de maior clareza. A liberalização do comércio deverá prosseguir de forma abrangente, incluindo o IR. Entender o contrário significaria abrir espaço para políticas individualistas com o fim de evitar a concorrência justa quanto à tributação da renda. No entanto, necessário conhecer com nitidez os efeitos da normatização da OMC sobre as normas tributárias indutoras, pois a identificação de uma estrutura- parâmetro do imposto de renda está sujeita a muitas variações, inclusive pela própria atuação do legislador doméstico ao realizar suas escolhas.

${ }^{234}$ Cf. G.V. Vettori, Contribuição ao estudo sobre as influências recíprocas entre a tributação da renda e o comércio internacional, p.137. 


\section{II.3 CONCLUSÕES DO CAPÍTULO}

II.3.1. A mudança da economia geopolítica para a global marca, definitivamente, a queda de barreiras étnicas, culturais, comunicacionais e comerciais. O Estado perde terreno em sua soberania. Por outro lado, as MNEs ganham poder decisório quanto à alocação de seus recursos, cuja destinação tem sido disputada, nos últimos anos, por praticamente todas as jurisdições. Cada qual procura mostrar-se mais atrativa a fim de conquistar o investidor estrangeiro.

II.3.2. A concorrência tributária internacional abordada pelo Report 1998 da OCDE, se traduz pela concessão geral de incentivos fiscais para atração do IED. Entretanto, cabe reconhecer que a atividade legislativa do Estado voltada para a fiscalidade influencia em sua competitividade. Por essa razão, a concorrência é vista sob o enfoque da indução (incentivos fiscais) e da fiscalidade (imposição fiscal). Neste giro, a decisão do legislador por uma política indutora ou pela norma impositiva de fins fiscais deverá ser avaliada em face das ordens tributária e econômica, não somente para averiguar se se presta ao fim colimado de atrair IED, como também se está conforme aos ditames constitucionais.

II.3.3. A concorrência tributária internacional, enquanto competição entre os Estados soberanos para atrair empresas multinacionais, acaba por exercer forte pressão na determinação da política fiscal do Estado, não apenas pela concessão de incentivos tributários, mas também de subvenção direta. Temendo perder receitas, haveria risco de o Estado reduzir sua imposição, agindo como presa de um sistema concorrencial ameaçador ao bem-estar de seus jurisdicionados. Essa foi a tônica da teoria tradicional da concorrência tributária que predominou nos anos 90.

II.3.4. À medida que os estudos sobre o tema avançaram, surgiram posições divergentes, sustentando não haver correlação entre tax competition e desgaste da base de tributação dos Estados. No seio da OCDE, por exemplo, não se constatou queda de arrecadação ou alteração de base tributária do capital para o trabalho ou consumo.

II. Países menos favorecidos por fatores locacionais e específicos afirmam que os incentivos fiscais são imprescindíveis à atração de IED. Contudo, a conclusão que se extrai dos estudos de Bénassy-Quéré; Fontagne e Lahreche-Revil mostra uma assimetria quanto à sensibilidade dos fluxos de IED na fonte. Alíquotas baixas não estimulam ou estimulam 
pouco, ao passo que alíquotas altas desestimulam substancialmente o investidor. Assim, países de alta pressão fiscal não deveriam se sentir estimulados a reduzir a tributação por meio de incentivos fiscais, mas considerar que o IED responde também ao potencial do mercado e aos bens públicos disponíveis como contrapartida pelo ônus tributário suportado.

II.3.5. A redução da tributação sem uma rigorosa avaliação de seus efeitos pode conduzir ao indesejável efeito carona (free riders). Isso significa que, ao desonerar o contribuinte que pagaria para desfrutar dos bens públicos disponíveis, inclusive do mercado, o Estado sobrecarrega os demais, certamente causando distorções e iniqüidades, sem qualquer benefício.

II.3.6. Pela via oposta, a concorrência tributária internacional pode apresentar aspectos positivos, tais como o acréscimo de bem-estar resultante da concorrência de entidades econômicas no mercado; opções ao agente privado para se fixar onde houver melhor relação entre ônus tributário e serviços e bens públicos ofertados; e limitações ao poder de tributar dos Estados que, por conseguinte, refream o gasto público, dada a necessidade de manter o equilíbrio orçamentário.

II.3.7. A concorrência lançou campanha pela nocividade dos paraísos fiscais, que, embora existentes há longa data, tornaram-se alvo direto de normas domésticas e internacionais, especialmente sob o comando da OCDE, voltadas ao combate da nocividade concorrencial. Inicialmente, paraísos fiscais representavam jurisdições que não tributavam ou tributavam pouco a renda. O principal critério definidor estava atrelado à imposição fiscal das jurisdições. Essa visão se alterou e hoje os paraísos fiscais são caracterizados, principalmente, por não cooperarem na troca de informações, valorando o sigilo e a opacidade societária.

II.3.8. A configuração de um sistema tributário competitivo requer medidas no campo da fiscalidade e da extrafiscalidade, além de outras referentes à atuação eficaz e harmônica de organismos ligados ao Executivo, Legislativo e Judiciário que, de alguma forma, participem da relação entre Estado e contribuinte, como fisco, cortes administrativas, legisladores e magistrados. A pós-modernidade exige transparência, agilidade e coerência nas respostas à sociedade internacional. Portanto, sistemas tributários podem ser 
competitivos sem se basearem, exclusivamente, em renúncia de receitas. Outros fatores devem ser considerados, como eficiência econômica da tributação, alíquotas tributárias competitivas, maximização do princípio da capacidade contributiva, simplicidade e transparência na tributação, além de qualidade da administração tributária.

II.3.9. A concorrência tributária também divide a opinião dos países. Para uns, é legítimo instrumento de desenvolvimento. Para outros, prejuízos injustos à economia doméstica. A verdade é que a tarefa de distinguir a concorrência tributária aceitável de da nociva não é tão simples. A fim de lhes demarcar a fronteira, sugere-se aplicar o exame de proporcionalidade, tomando como fim a atração ao IED e como medida concreta para que este fim seja alcançado, a concessão de incentivos fiscais. Os testes de adequação, necessidade e proporcionalidade stricto sensu da medida devem garantir sua harmonia ou incompatibilidade com a ordem internacional, demarcando o limite entre concorrência aceitável e nociva; e interna, apontando eventual inconstitucionalidade.

II.3.10. As balizas do ordenamento à concorrência são impostas por diversos vetores constitucionalmente previstos. Sob a ordem tributária, o estudo das normas concretas de tributação da renda com vistas à competitividade brasileira deve ser realizado à luz da igualdade, cujo corolário maior é a capacidade contributiva. Concessões à praticabilidade serão feitas, mas desde que não ultrapassem o limite que as torne uma violação da igualdade. Do mesmo modo, a norma tributária não poderá conceder vantagens concorrenciais, devendo permanecer neutra quanto possível. Todas essas balizas devem funcionar coerentemente, sob o crivo da razoabilidade.

II.3.11. Fiscalidade e indução também se sujeitam ao crivo da ordem econômica, que impõe limitações à tributação da renda na ordem doméstica e na internacional. O plano global normativo imposto pela Constituição encontra-se no Título VII - Da Ordem Econômica e Financeira, logo a seguir, e não por acaso, ao Título VI- Da Tributação e do Orçamento. A lógica espacial da Carta Política vai ai encontro da dupla atribuição de predicados que se dá à norma sob exame (diádica): em primeiro lugar, tributária - sujeita á ordem tributária; e, em segundo, indutora - adentrando ao espaço econômico não como figurante, mas atora capaz de auxiliar na concretização dos programas, diretrizes e fins visados pela Constituição Econômica. O constituinte, ao ditar a ordem econômica, baseouse na valorização do trabalho, da livre iniciativa e da livre-concorrência, com o fim de 
assegurar existência digna a todos. Assim é que a norma tributária, voltada para indução ou fiscalidade, deve, forçosamente, respeitar a resultante dos diversos vetores voltados para a justiça social.

II.3.12. No plano internacional, a ordem econômica se impõe, precipuamente, pela regulação exercida através da OMC, cuja atuação contra o protecionismo está alicerçada nos princípios da nação mais favorecida, tratamento nacional, liberalização do comércio, transparência e competição justa.

II.3.13. O legislador deve, forçosamente, atuar para o estabelecimento de um ambiente favorável aos fluxos de IED. Ocorre que para a consecução desta finalidade não atua livremente, mas vinculado aos mandamentos constitucionais da ordem tributária e econômica, seja sua atuação pela imposição fiscal ou pela renúncia de receitas. $\mathrm{Na}$ verdade, pesa sobre o legislador doméstico, ainda, o guante da ordem internacional, seja pelos arranjos bilaterais para evitar a bitributação, seja pelo vínculo a organismos multilaterais como a OMC.

II.3.14. Assumindo que a questão da competitividade não se baseia, exclusivamente, na redução de alíquotas ou de imposição fiscal, renunciar receitas pode não se configurar medida eficaz na atração do IED e ainda gerar o efeito carona. Em todo o caso, paralelamente à política de renúncia de receitas planejada e de efeitos calculados, alternativa segura ao legislador brasileiro estaria na criação de condições de macroestabilidade que desenvolverão o ambiente favorável aos fluxos de IED. Para tanto, há que se melhorar a harmonia dos serviços prestados pelo Executivo, Legislativo e Judiciário quanto às relações com os contribuintes e investir em outros fatores de alocação das empresas, como desenvolvimento de tecnologias, infra-estrutura de transporte, mão-deobra e outros. 


\section{CAPÍtulo III- A TRIBUTAÇÃo COMO MEIO DE ATRAÇÃo AO INVESTIMENTO ESTRANGEIRO DIRETO}

\section{III.1 INCENTIVOS FISCAIS - REGULAÇÃO E EFICIÊNCIA}

\section{III.1.1 Normas Tributárias Indutoras}

Os incentivos físcais não são novidade na política de atração de investimentos dos países. Com efeito, políticas de desoneração tributária têm sido utilizadas em larga escala, com diversos fins, independente do grau de desenvolvimento dos Estados. Em matéria de Imposto de Renda, pode-se citar o Reino Unido por ter sido o primeiro, em 1880, no uso da tributação como meio de indução econômica; a Alemanha, cuja reconstrução após a $2^{\mathrm{a}}$ Guerra foi alavancada pelos incentivos fiscais e subsídios; e os EUA, que desde o governo Reagan promoveram redução do imposto de renda mantendo uma política de incentivos fiscais até os dias atuais. ${ }^{1}$

Na pós-modernidade, dada a fluidez com que os fatores de produção podem se locomover, fatores atinentes ao imposto de renda corporativo ganham cada vez mais peso na decisão de alocação do IED. ${ }^{2}$ Assim, muito embora seja lícito tentar atrair o capital com vistas ao desenvolvimento, cada Estado deve observar quais as balizas para implantação de políticas tributárias concessivas, considerando o ordenamento doméstico e o internacional.

Para lograr êxito na atração do IED, o Estado dispõe de instrumento a seu favor: a norma tributária indutora. Schoueri leciona que, para bem identificá-la, deve-se priorizar o enfoque pragmático, aquele que se debruça sobre os efeitos da norma

\footnotetext{
${ }^{1}$ ELALI, André. Incentivos fiscais internacionais - concorrência fiscal, mobilidade financeira e crise do Estado. São Paulo: Quartier Latin, 2010, pp. 112-114. Na gestão Obama, a política de desoneração fiscal tem se concentrado em combater a crise financeira, sem descuidar dos investimentos e atração de capital. Assim, incentivos fiscais norte-americanos têm sido destinados ao desenvolvimento de um ambiente propício ao pequeno e o médio empresário e à produção e invenção de alta tecnologia. Adicionalmente, permanece a preocupação em manter multinacionais em solo norte-americano, bem como atrair novas empresas, ocupando, o País, a primeira posição do rol dos que mais receberam IED em 2010. Cf. UNCTAD, World Investment Report 2011, p.4. Disponível em: http://www.unctad.org/Templates/webflyer.asp?docid=15189\&intItemID=2068\&lang=1 \&mode=downloa ds. Acesso em 10 out 2011. Para maiores detalhes sobre o tema, v. The president's record on jobs and the economy. Disponível em http://www.barackobama.com/record/economy/. Acesso em $20 \mathrm{dez} 2011$.

${ }^{2} \mathrm{Cf}$. OCDE, Taxing profits in a global economy-domestic and international issues, p. 21.
} 
tributária sobre o contribuinte. ${ }^{3}$ Não bastaria, pois, avaliar apenas a intenção do legislador, mas a função da norma tributária, que sempre seria arrecadadora, facultandose-lhe, ainda, desempenhar função distributiva (justiça fiscal), indutora ou simplificadora (praticabilidade). ${ }^{4}$

Em ambiente de competição internacional, parece mesmo verdadeiro, e até mais grave, que a mera decisão do legislador de um Estado "A" em manter seus níveis de imposição tributária represente a fuga do investidor para o Estado "B", onde há tratamento mais benéfico ao capital, sob o ponto de vista tributário. Este exemplo confirma a inadequação de medição do efeito indutor na norma tributária pelo simples desiderato do legislador (critério teleológico). Em "A", sua aparente "neutralidade" induziu o investidor a migrar, representando verdadeiro desestímulo a que permanecesse. Considerando, ainda, por hipótese, que, em "B”, o legislador visasse apenas a renunciar receitas por conta de dificuldades orçamentárias em transferi-las, diretamente, a um específico setor produtivo, o efeito da norma acabou por atrair IED sem que essa tivesse sido sua intenção.

Tipicamente, o Estado hipotético "B" bem poderia ser um país emergente, pois, de fato, costuma atuar pela via da renúncia de receitas (gastos tributários), justo pela dificuldade em obtê-las. Já os países desenvolvidos, em geral, costumam adotar as

\footnotetext{
${ }^{3}$ Cf. L.E. Schoueri, Normas tributárias indutoras, p. 4. Acresça-se que há três planos de investigação semiótica: o sintático, o semântico e o pragmático. Todos influenciam na análise da linguagem jurídica, enquanto visam a disciplinar relações intersubjetivas utilizando-se de ordens e sanções. A sintaxe, de natureza hermética, se debruça sobre a relação intersígnica, desprezando ocorrências que se dão fora do sistema. No âmbito do sistema jurídico-normativo, vê-se a sintaxe na inter-relação de normas, como ocorre no confronto entre normas veiculadas sob distintas espécies legais. Outra relação sintática é a que vincula a regra sancionadora à outra que firma o dever. Apresenta-se, ainda, a relação sintática de forma intranormativa, ditando a relação condicional entre hipótese e conseqüente. Em todos os exemplos supramencionados pode-se verificar a relação existente entre os símbolos (normas) de dado sistema (jurídico-normativo). O plano semântico projeta-se sobre o mundo real. É ele quem liga o símbolo utilizado ao objeto real, exterior ao sistema. Sob o prisma jurídico, pode-se entender a semântica como a relação entre a norma e os fatos que alcança, o que nem sempre é facilmente realizável, dada a gama de significações que palavras ou enunciados podem ensejar em vista de imprecisões, ambigüidades ou diversidade de sentidos. Destarte, apresenta-se a linguagem jurídica sob influência semântica quando se busca a acepção correta dos vocábulos empregados no texto jurídico, suas denotações e conotações. Todavia, há que se observar o pragmatismo dos utentes da linguagem a fim de que se avalie seu uso em diferentes funções. A linguagem jurídica pode assumir uma função prescritiva, dotada de valores lógicos dissociados daqueles que regem a Lógica Clássica - fundados em premissas de verdade e falsidade -, baseados que estão na idéia de validade ou invalidade, nos moldes da Lógica Deôntica; ou mesmo uma função propriamente persuasiva, quando tiver por fim principal a tarefa de convencer. À função pragmática, portanto, cabe conhecer como a linguagem jurídica é utilizada pelos sujeitos em suas comunidades, cumprindo sua tarefa de disciplinar condutas. V. P.B. Carvalho, Direito tributário, linguagem e método, p.30-66.

${ }^{4}$ Cf. L.E. Schoueri, Normas tributárias indutoras, pp.27-28. O autor referencia o trabalho de Klaus Vogel (Die Abschichtung Von Rechtsfolgen im Steuerrecht, Steuer und Wirtschaft, n²/1977) por sua relevância em não apartar a função arrecadadora da indutora, uma vez que " a norma indutora não deixa de gerar alguma arrecadação".
} 
subvenções diretas, transferindo recursos do orçamento, pela via das despesas, ao setor econômico que pretenda estimular.

Ao sustentar a inadequação do critério finalístico, Schoueri alega que à finalidade indutora da norma tributária, poderiam se juntar outras, a depender da intenção do legislador. $\mathrm{O}$ fato de uma norma ter fim indutor não impediria, pois, que também possuísse, por exemplo, fim arrecadador ou distribuidor, o que dificultaria a faina identificadora. ${ }^{5}$

Além disso, à busca por um fim fiscal (arrecadador) deveria se opor um fim extrafiscal (não arrecadador), casando-se os limites do primeiro aos contornos do princípio da capacidade contributiva. Destarte, a norma indutora não poderia apresentar conformação ao referido princípio. A divisão entre fim fiscal e extrafiscal em nome da capacidade contributiva não merece prosperar. A uma porque o princípio tem contornos abstratos, ensejando discussões doutrinárias; a duas, pelo fato de uma norma indutora poder se conformar com o princípio em tela, como não raras vezes ocorre. ${ }^{6}$

Mais seguro, portanto, seria valer-se do plano pragmático para a identificação da norma tributária indutora. Nesse caso, o foco estaria sobre os efeitos objetivos da norma sobre os contribuintes, medido pelo grau de eficácia da função desempenhada pela norma (funções eficaciais). Fica claro, neste contexto, que a norma poderá produzir maiores ou menores efeitos indutores, arrecadadores, distribuidores ou simplificadores e que os fins fiscais e extrafiscais não são antagônicos e excludentes, necessariamente. ${ }^{7}$

Portanto, sempre que a norma tributária desempenhar função de indução, vinculando, ao comportamento do contribuinte, um conseqüente normativo estimulante (incentivos) ou desestimulante (desincentivos), será possível identificar uma norma tributária indutora. ${ }^{8}$

Acresça-se, ainda, que o efeito medido sobre o comportamento do destinatário da norma tributária indutora - in casu, o investidor externo- tem caráter imediato, devendo conformar-se a um efeito maior, mediato, que seria a promoção de determinada política pública conforme os objetivos fundamentais do País. A norma tributária deverá induzir o comportamento do destinatário da norma e, conseguintemente, promover o

\footnotetext{
${ }^{5}$ Cf. L.E. Schoueri, Normas tributárias indutoras, p.25.

${ }^{6}$ Cf. L.E. Schoueri, Normas tributárias indutoras, pp.23-25. O autor exemplifica a tributação dos juros sobre capital próprio, prevista no art. $9^{\circ}$ da Lei 9.249/95, cujas normas tinham por fim capitalizar as empresas (indução), garantindo ao investidor a mesma tributação do mercado financeiro de renda fixa (respeito à capacidade contributiva).

${ }^{7}$ Cf. L.E. Schoueri, Normas tributárias indutoras, p. 40.

${ }^{8}$ Cf. L.E. Schoueri, Normas tributárias indutoras, p. 40.
} 
ideário de justiça. Com efeito, a desoneração tributária que somente aproveite ao investidor migrante sem proveito à coletividade do Estado indutor não parece conforme ao Estado de Direito.

Tome-se o exemplo de lei específica que conceda isenção por 10 anos (tax holidays) para a empresa estrangeira aqui se fixar, o que, de fato vem a ocorrer. Tratarse-ia de norma tributária indutora. Durante o tempo do benefício, necessário considerar a receita renunciada para aferição do custo dessa política indutora, ao qual deverão corresponder objetivos critérios de aferição do bem-estar gerado à coletividade. Considerando que a norma tributária indutora não é um fim em si mesmo, ela precisa concretizar os ideais de justiça tributária. Caso não seja possível aferir o benefício social por imperícia ou negligência do Estado, melhor seria arrecadar o correspondente recurso e aplicá-lo, pela via da despesa orçamentária.

Neste mesmo exemplo, difícil verificar a função arrecadadora na norma tributária, especialmente considerando a economia globalizada e o fato de que o investidor resolveu mudar-se após 9 anos e 11 meses de residência, em vista de novos incentivos fiscais em outra jurisdição. ${ }^{9}$

Através de uma política concessiva de incentivos fiscais para a atração de IED, age indiretamente o Estado com vistas a estimular o comportamento do agente econômico. Não se trata aqui do Estado-empresário, diretamente atuando no domínio econômico, mas do Estado cuja atuação se dá por incentivos, meramente sobre o domínio econômico, ou seja, sobre a atividade econômica stricto sensu, aquela tipicamente privada, dissociada do serviço público. ${ }^{10}$ Como exemplo, inter alia, tem-se isenções, reduções de base de cálculo, reduções de alíquotas e remissão.

Embora a intervenção por indução em matéria tributária tenha finalidade legítima em um Estado de Direito - desenvolvimento nacional, erradicação da pobreza, redução de desigualdades regionais etc.-, cabe ressaltar que a Carta Magna define os limites de atuação do Estado nesta área. O que para uns é benefício, para outros pode significar tratamento discriminatório. Ademais, para além dos filtros típicos da matéria

\footnotetext{
${ }^{9}$ Schoueri alega que a função arrecadadora sempre estará presente na norma tributária, seja de forma positiva ou negativa. V. Cf. L.E. Schoueri, Normas tributárias indutoras, p. 40.

${ }^{10}$ Eros Grau define intervenção como atuação na área de outrem. Neste caso a atuação do Estado no domínio econômico, cuja classificação se divide em: (i) intervenção por absorção ou participação: respectivamente quando o Estado controla totalmente os meios de produção ou troca em determinado setor (monopólio) e quando exerce um controle parcial, competindo com empresas do setor privado; (ii) intervenção por direção: O Estado pressiona os agentes econômicos ditando-lhes comportamentos obrigatórios; e (iii) intervenção por indução: o Estado manobra os instrumentos de intervenção conforme as leis de mercado. V. GRAU, Eros Roberto. A ordem econômica na Constituição de 1988 -interpretação e crítica. 8.ed. São Paulo: Malheiros editores, 2003, pp. 126-127.
} 
tributária, as normas tributárias indutoras devem submeter-se ao crivo da Constituição Econômica, já que produzirá efeitos no âmbito de sua abrangência. ${ }^{11}$

III.1.2 Benefícios fiscais: gastos tributários e subvenções diretas

Inobstante a variação terminológica, adota-se, aqui, o termo benefícios fiscais como gênero de auxílios concedidos aos contribuintes, sejam eles pela via do direito tributário -incentivos fiscais ou tributários- ou pela do direito financeiro transferências diretas ou subvenções (stricto sensu).

Segundo o art. $12, \S^{\circ}$, da Lei 4.320/64, subvenções seriam transferências destinadas a cobrir despesas de custeio das entidades beneficiadas, subdividindo-se em:

(i) subvenções sociais, as que se destinem a instituições públicas ou privadas de caráter assistencial ou cultural, sem finalidade lucrativa;

(ii) subvenções econômicas, as que se destinem a empresas públicas ou privadas de caráter industrial, comercial, agrícola ou pastoril.

Parece lícito, portanto, entender, em sentido estrito, subvenções como benefícios orçamentários correspondentes a transferências diretas do poder público a empresas de determinado setor econômico. Trata-se, pois, de indução por meio de norma financeira, cujo resultado equivale ao produzido pela indução por meio de norma tributária.

Sob a óptica jurídica, as subvenções não poderiam se confundir com os incentivos fiscais, já que pressupõem um desembolso real, visível, na previsão e na execução orçamentárias. Já os incentivos fiscais ocorrem pela renúncia na via das receitas, reduzindo a arrecadação, de modo que o Estado abdica de receitas que, salvo por tais incentivos, deveria, normalmente, recolher a seus cofres.

No entanto, sob o prisma financeiro, indifere a via formalmente escolhida para induzir o comportamento do agente econômico, se pela coluna da receita pública (isenção, redução de base de cálculo ou alíquota, depreciações para efeito do imposto de

\footnotetext{
11 Normas tributárias indutoras devem, igualmente, se conformar aos contornos da Constituição Financeira, não apenas em seu aspecto formal - preenchimento de relatórios e demonstrativos, consecução de índices econômicos -, mas, sobretudo, em seu aspecto material, concretizador dos pilares do Estado de Direito. Uma análise neste sentido, no entanto, está fora do escopo desta tese.
} 
renda etc.) ou da despesa pública (subvenção, subsídio, restituição de impostos etc.). Ao cabo, materialmente, será produzido o mesmo resultado econômico. ${ }^{12}$

Pode-se, portanto, considerar incentivos fiscais e subvenções stricto sensu como espécies de subvenções lato sensu. Este mesmo sentido parece ter sido contemplado pela Lei de Responsabilidade Fiscal - LRF, ${ }^{13}$ ao considerar incentivos promovidos por subvenções diretas (subsídios) dentre as hipóteses de renúncia de receita. $^{14}$

Os incentivos pela via das receitas tornaram-se conhecidos como gastos tributários (tax expenditures). ${ }^{15}$ A origem dessa expressão remonta aos trabalhos de Stanley Surrey, em 1967, então Secretário de Política Fiscal do Tesouro dos EUA, que consagrou o termo ao fazer referência a dispositivos da legislação do imposto de renda que, embora estranhos à estrutura do imposto, promoviam desoneração tributária. ${ }^{16}$

Desde então, o termo ganhou o mundo. Organizações internacionais da envergadura da OCDE, FMI e CEPAL passaram a recomendar a inclusão dos gastos tributários nos orçamentos nacionais, o que, de fato, tornou-se prática em vários países, a despeito da falta de uniformidade internacional no tocante à metodologia de cálculo e à abrangência dos gastos a considerar. Alguns apuram a desoneração apenas dos tributos sobre a renda; outros, da tributação sobre o consumo; outros, ainda, incluem tributos previdenciários, como é o caso brasileiro. ${ }^{17}$

\footnotetext{
12 TORRES, Ricardo Lobo. Curso de direito financeiro e tributário. 12. ed. Rio de Janeiro: Renovar, 2005, p. 194. Neste mesmo sentido, L.E. Schoueri, Normas tributárias indutoras, p. 58.

${ }^{13}$ LC 101/00.

${ }^{14}$ LRF, art. 14, § $1^{\circ}$ A renúncia (de receitas) compreende anistia, remissão, subsídio, crédito presumido, concessão de isenção em caráter não geral, alteração de alíquota ou modificação de base de cálculo que implique redução discriminada de tributos ou contribuições, e outros benefícios que correspondam a tratamento diferenciado. (grifo nosso). Os subsídios podem ser entendidos como espécie do gênero subvenções stricto sensu, especialmente voltados para estimular exportações ou determinado ramo industrial ou empresa. Cf. L.E. Schoueri, Normas tributárias indutoras, pp. 210-211.

${ }^{15}$ Inobstante a expressão gastos tributários não ser unânime para traduzir tax expenditures, será adotada com este sentido neste trabalho. Gustavo Vettori defende que não haveria tradução perfeita para o termo tax expenditures, que, mesmo em língua inglesa não está imune a críticas, havendo preferência por negative income tax ou tax subsidiy. Cabíveis para este mister seriam inter alia gastos fiscais, subvenções fiscais, incentivos fiscais, benefícios fiscais. V. VETTORI, Gustavo Gonçalves. Contribuição ao estudo sobre as influências recíprocas entre a tributação da renda e o comércio internacional. Tese de doutorado - Faculdade de Direito da USP, São Paulo, 2011, pp. 10-11.

${ }^{16}$ Após 1975, o orçamento norte-americano passou a dispor de um demonstrativo dos tax expenditures, o que inspirou o $\$ 6^{\circ}$ do art. $165^{16}$ da Constituição Federal brasileira.Cf. TORRES, Ricardo Lobo. Tratado de direito constitucional financeiro e tributário, volume III; os direitos humanos e a tributação: imunidades e isonomias. Rio de Janeiro: Renovar, 1999, p.355.

${ }^{17}$ PUREZA, Maria Emilia Miranda. Disciplinamento das renúncias de receitas federais - inconsistências no controle dos gastos tributários, pp.5-6. Disponível em: http://www2.camara.gov.br/atividadelegislativa/orcamentobrasil/orcamentouniao/estudos/2007/Estudo052007.pdf. Acesso em 07 set. 2011.
} 
O desafio do Estado reside em induzir o comportamento do investidor externo sem descurar do controle eficaz dos incentivos fiscais. Na verdade, o Estado vê-se obrigado à preservação do equilíbrio das contas públicas e ao dever de transparência para com a sociedade. Observa-se que as maiores dificuldades no controle dos incentivos não se encontram na via da despesa, pelas transferências diretas registradas no orçamento, mas na via das receitas, onde os gastos tributários desfalcam a estimativa de receitas orçamentárias.

A grande dificuldade em lograr êxito sobre o controle dos gastos tributários, ou, em outra medida, da política de incentivos fiscais pela via tributária, reside em um problema conceitual quanto ao que seria a já referida estrutura do imposto parâmetro. $^{18}$

Dever-se-ia partir dessa estrutura do imposto para identificar os desvios cujo resultado fosse a desoneração tributária. Entretanto, longe de ser tarefa singela, a escolha de critérios capazes de qualificar o gasto tributário varia conforme o tratamento conferido por cada ordenamento doméstico. Como cada país tem seus próprios interesses e encontra-se em determinada posição perante a sociedade internacional, natural que atuem de forma variada na busca por maior competitividade. Daí resulta a necessidade de mensuração dos gastos tributários, sem a qual se torna impossível conhecer de sua juridicidade. ${ }^{19}$

A Receita Federal do Brasil elabora o Demonstrativo de Gastos Tributários desde $1988,{ }^{20}$ em atendimento às previsões da CF, art. $165, \S 6^{\circ}$ e da LRF, art. $5^{\circ}$, II. $^{21}$

\footnotetext{
${ }^{18}$ V. tópico II.2.3.2.

${ }^{19}$ Veja-se, a esse respeito, a intenção do constituinte em excepcionar a uniformidade geográfica, insculpida no art. 151, I da CF, para promover "o equilíbrio do desenvolvimento socioeconômico entre as diferentes regiões do País", admitindo, para tanto, a concessão de incentivos fiscais. Pois bem, embora haja a preocupação do constituinte em desenvolver harmonicamente os entes federativos, não significa tal possibilidade um cheque em branco nas mãos do legislador federal. Assim é que, para fins de controle, a Constituição (art. $165, \S 6^{\circ}$ ) exige que o projeto de lei orçamentária seja acompanhado de demonstrativo regionalizado do efeito, sobre as receitas e despesas, decorrente de isenções, anistias, remissões, subsídios e benefícios de natureza financeira, tributária e creditícia. A Carta Política (art. 70) dispõe, ainda, sobre o controle das subvenções e renúncia de receitas pelo Congresso Nacional, para o que conta com o auxílio do Tribunal de Contas da União. Em complemento à Constituição, a LRF, em seu art. 14, exige que a concessão ou ampliação de incentivo ou benefício de natureza tributária, da qual resulte renúncia de receitas, deve se fazer acompanhar de estimativa do impacto orçamentário-financeiro no exercício em que deva iniciar sua vigência e nos dois seguintes.

${ }^{20} \mathrm{Na}$ realidade, o fisco preparava o Demonstrativo de Benefícios Tributários, no período entre 1988 e 2003. "Porém, o conceito de benefício tributário adotado na elaboração desse demonstrativo não embutia a ótica orçamentária. Em conseqüência, alguns benefícios tributários relacionados pela RFB não se enquadravam na conceituação de gastos tributários e alguns gastos tributários não estavam relacionados entre os benefícios tributários constantes no demonstrativo". Em 2004, passou a ser elaborado o Demonstrativo de Gastos Tributários, que refletindo um aprimoramento do "conceito utilizado e promovendo uma maior uniformização com o entendimento utilizado em outros países", levou a RFB a utilizar o termo "gasto tributário" em substituição ao termo "benefício tributário". Cf. RECEITA
} 
Embora tal demonstrativo represente um avanço no controle dos incentivos fiscais, há limitações na própria conceituação dos gastos tributários que abrem campo a interpretações distintas, dificultando o controle sobre determinados tratamentos eventualmente excluídos do conceito.

Sem que a sociedade conheça as subvenções concedidas pela via tributária, impossível lhes reconhecer a utilidade. Nesta esteira, Pureza alerta que a diversidade de concepções acerca do conceito de gastos tributários pode ser prejudicial quanto à tomada de "decisões minimamente consistentes em relação a políticas públicas que envolvam a concessão de incentivos ou benefícios fiscais." Além disso, as falhas de consistência na divulgação dos dados, que daí decorrem, podem comprometer a credibilidade dos órgãos públicos quanto à apuração dos dados. ${ }^{22}$

Gustavo Vettori, em sua tese de doutorado pela Faculdade de direito da USP, lança crítica ao conceito de gasto tributário, uma vez que corresponderia a desvios de um parâmetro de tributação. Ocorre que a identificação do que seria a estrutura do imposto, o parâmetro de comparação, enseja miríade de interpretações que tornam o conceito mais ou menos largo. ${ }^{23}$ Em suas análises, Vettori reconhece que um parâmetro inicial em termos de imposto de renda poderia ser o próprio conceito de renda. Ocorre que este está longe de ser um conceito unívoco, já que cada Estado define renda segundo seus interesses, razão pela qual urge considerar, para a determinação do parâmetro da tributação da renda, (i) sujeito passivo; (ii) base de cálculo; (iii) cédulas; (iv) deduções e abatimentos; (v) dupla tributação econômica; (vi) dupla tributação jurídica; (vii) período de apuração; e (viii) inflação. ${ }^{24}$

FEDERAL DO BRASIL. Demonstrativo dos gastos tributários 2011. Brasília, 2010, p.8. Disponível em: http://www.receita.fazenda.gov.br/publico/EstudoTributario/BensTributarios/2011/DGT2011.pdf. Acesso em 24 set 2011.

${ }^{21}$ o parágrafo $6^{\circ}$ do art. 165 da Constituição Federal, que estabelece a obrigação de o Poder Executivo apresentar demonstrativo regionalizado do efeito, sobre as receitas e despesas, decorrente de isenções, anistias, remissões, subsídios e benefícios de natureza tributária, financeira e creditícia; e, o inciso II do art. 5. ${ }^{\circ}$ da Lei Complementar n. ${ }^{\circ} 101$, de 04 de maio de 2000, que estabelece que o projeto de lei orçamentária anual (LOA) será acompanhado de documento a que se refere o $\S 6^{\circ}$ do art. 165 da Constituição Federal, bem como das medidas de compensação de renúncias de receita e do aumento de despesas obrigatórias de caráter continuado. Cf. RFB, Demonstrativo dos gastos tributários, p.5.

${ }^{22}$ Cf. M.E.M.Pureza. Disciplinamento das renúncias de receitas federais - inconsistências no controle dos gastos tributário, p.5

${ }^{23}$ Cf. G.G.Vettori, Contribuição ao estudo sobre as influências recíprocas entre a tributação da renda e o comércio internacional, pp.29-30.

${ }^{24}$ Cf. G.G.Vettori, Contribuição ao estudo sobre as influências recíprocas entre a tributação da renda e o comércio internacional, pp.32-35. 
Um imposto de referência (parâmetro) consagrou-se no cenário internacional, sendo, inclusive, recomendado pela OCDE em seu Best practices guidelines: off budget and tax expenditures 2004, conforme noticiam Lemgruber e Villela. Esses financistas dão, ainda, notícia de três enfoques amplamente utilizados pelos países para definir o imposto-parâmetro e identificar os gastos tributários: ${ }^{25}$

(i) enfoque conceitual: não guarda relação com a definição legal do imposto. Assim, a referência passa a ser um conceito, como, por exemplo, o modelo SHS para renda. ${ }^{26}$ Produz um conceito mais amplo que os demais, resultando em maior volume de gastos tributários;

(ii) enfoque legal: baseia-se na ordem jurídica posta para obter o imposto de referência e, a partir daí, identificar os gastos tributários; e

(iii) enfoque do subsídio análogo: gastos tributários seriam aquelas concessões análogas à subvenção direta. Na prática, produz resultados semelhantes ao enfoque legal.

A Receita Federal do Brasil utiliza o enfoque legal, adotando a legislação do imposto de renda como parâmetro cujas características são as seguintes: ${ }^{27}$

(i) contribuintes em situações equivalentes devem estar sujeitos a obrigações similares (eqüidade);

(ii) contribuintes com maior renda podem estar sujeitos a obrigações mais que proporcionais que os de menor renda (proporcionalidade);

(iii) a tributação não deve alterar a alocação dos recursos na economia (neutralidade);

Toda desoneração que promover desvios em relação a essas características e, ao mesmo tempo, tiver a intenção de promover alguma ação de governo será considerada um gasto tributário.

Segundo a sistemática brasileira, gastos tributários são gastos indiretos do governo realizados por intermédio do sistema tributário, visando atender objetivos econômicos e sociais. São explicitados na norma que referencia o tributo, constituindose uma exceção ao sistema tributário de referência, reduzindo a arrecadação potencial

\footnotetext{
${ }^{25}$ Os autores se baseiam no estudo realizado por J. Craig e W. Allan, Fiscal transparency, tax expenditures, and budget processes: an international perspective. NTA Papers and Proceedings, 2001. LEMGRUBER, Andréa; VILLELA, Luiz. O desafio de medir os gastos tributários. In: SOUSA, M.C.S.de; COELHO, I.; VERSIANI, F.R.; TANNURI-Pianto, M.E. (org.), Economia pública brasileira. Brasília: Escola de Administração Fazendária, 2010, p. 181.

${ }^{26} \mathrm{O}$ modelo SHS, em resumo, considera renda o acréscimo patrimonial obtido em dois momentos acrescido do consumo e da renda imputada. V. tópico IV.1.1 sobre o conceito de renda.

${ }^{27}$ Cf. RFB, Demonstrativo dos gastos tributários 2011, p.8.
} 
e, conseqüentemente, aumentando a disponibilidade econômica do contribuinte. Têm caráter compensatório, quando o governo não atende adequadamente a população dos serviços de sua responsabilidade, ou têm caráter incentivador, quando o governo tem a intenção de desenvolver determinado setor ou região. ${ }^{28}$

Para identificar os gastos tributários, a RFB vale-se da regra dos dois passos: ${ }^{29}$

$1^{\circ}$ Passo: determinar todas as desonerações tributárias tomando como base um sistema tributário de referência; e,

$2^{\circ}$ Passo: avaliar, utilizando os critérios definidos no conceito acima, quais desonerações são gastos indiretos passíveis de serem substituídas por gastos diretos, vinculados a programas de governo.

Para Vettori, essa conclusão da administração brasileira incorre em erro. Sustentado pela idéia de que o sistema tributário não se divide em normas de arrecadação (estrutura do imposto: equidade, progressividade e neutralidade) e normas de subvenção (desvio), defende que a norma tributária sempre apresentará a função arrecadadora e a indutora, o que impede a segregação da análise das subvenções em dois momentos: um primeiro de definição do parâmetro, e um segundo em que se apuram os desvios. Conclui, então, que o mais correto seria identificar as regras que concretizam a política pública pela via da tributação para, em seguida, diferenciá-las das demais desprovidas desse propósito. Só então seria possível calcular a subvenção. ${ }^{30}$

A verdade é que o modelo brasileiro de cálculo dos gastos tributários não está isento de críticas, como o de nenhum Estado estará. Como já alertado, a estrutura parâmetro do imposto requer a adoção de critérios, como equidade, proporcionalidade, neutralidade, que estão longe de representar unanimidade quanto aos seus contornos e efeitos. Não se pode desprezar, ainda, a peculiaridade de cada Estado em vista de seus interesses na definição dos gastos tributários. Certo é que, inobstante metodologias criticáveis, o controle sobre os gastos tributários é obrigatório por comando constitucional, exigindo-se seu constante aprimoramento para evitar a discriminação que repercute diretamente na esfera da isonomia e da livre-concorrência.

\footnotetext{
${ }^{28}$ Cf. RFB, Demonstrativo dos gastos tributários 2011, p.11.

${ }^{29}$ Cf. RFB, Demonstrativo dos gastos tributário 2011, p.11.

${ }^{30}$ Cf. G.G.Vettori, Contribuição ao estudo sobre as influências recíprocas entre a tributação da renda e o comércio internacional, p.39 e p. 44.
} 
Não se tem por objetivo buscar a máxima precisão conceitual do instituto. Importa-nos, sim, que a mera fluidez do conceito de gasto tributário não impeça o controle efetivo, não apenas formal, mas material, sobre a indução pela via tributária. Não apenas a apresentação de demonstrativos, mas a efetiva fiscalização e correção dos desvios que possam surgir pela via das renúncias, já que são mais facilmente implantadas que as transferências diretas.

Evoque-se, se necessário, um enfoque mais pragmático, exeqüível, calcado na praticabilidade, traduzida pelo "conjunto de técnicas que visam a viabilizar a adequada execução do ordenamento jurídico," ${ }^{31}$ para o efetivo controle dos gastos tributários. Afinal, há conceitos outros, por demais fluidos, que nem por isso deixam de ser normatizados. A própria renda enseja discussões várias quanto aos seus exatos contornos, mas essa não é a causa para sua intributabilidade. A praticabilidade, em favor da tributação, vence muitos dos obstáculos impostos pela abstração conceitual de renda, do mesmo modo que, a benefício da accountability, da responsabilidade na gestão pública, da boa-fé objetiva, da proteção da confiança do contribuinte no Estado, deverá, da mesma forma, ser evocada para justificar os mecanismos de controle de renúncia de receitas públicas.

Registre-se que a mensuração de gastos tributários por meio de demonstrativos elaborados pelo fisco é mero retrato das escolhas efetuadas pelo legislador. A este compete a regulação econômica por meio de normas tributárias indutoras. Questões, portanto, de ordem política terão peso fundamental na decisão do Estado em desembolsar recursos ou renunciá-los. Certo é que a concessão de benefícios fiscais deve ser legítima e buscar eficiência econômica. Logo, gastos tributários que violem o ordenamento jurídico e, ao invés de benefícios, gerem dificuldades econômicas e sociais não podem ser legítimos e eficientes. ${ }^{32}$

Crescentemente, o legislador brasileiro tem optado pela via dos gastos tributários, sendo que entre 2004 e 2010, os gastos tributários brasileiros saltaram de $1,40 \%$ para $3,42 \%$ do PIB, e o imposto de renda foi renunciado em $40 \%$ do seu total em 2010. ${ }^{33}$ Importa conhecer não o registro do quanto foi renunciado no demonstrativo elaborado pela RFB, mas a motivação e os resultados comprovados de que não houve

\footnotetext{
${ }^{31}$ COSTA, Regina Helena. Praticabilidade e justiça tributária. São Paulo: Malheiros Editores, 2007, p.53.

${ }_{32}$ Cf. A. Elali, Incentivos fiscais internacionais, p. 123.

${ }^{33}$ Cf. A. Lemgruber e L. Villela, O desafio de medir os gastos tributários, pp.192-193
} 
prejuízos à igualdade que deve reinar no mercado, balizada pela livre concorrência e pela livre iniciativa.

Infelizmente, porém, o controle brasileiro sobre os gastos tributários ainda é deficitário, pois: ${ }^{34}$

(i) gastos subnacionais, a despeito da importância de sua arrecadação, não são sistematicamente preparados, o que gera subavaliação dos gastos tributários;

(ii) o marco legal e as instituições envolvidas na identificação dos gastos tributários, nos três níveis de governo, não estabeleceram suas metodologias de forma clara, dificultando a agregação dos dados nacionais;

(iii) a legislação concessiva carece de racionalização e transparência;

(iv) não há qualquer estrutura institucional para realizar avaliações permanentes sobre a relação entre os fins almejados e os custos impostos pela política indutora. Ao contrário, o legislador aumenta substancialmente os gastos tributários sem qualquer rigidez de controle e participação efetiva da sociedade.

Naturalmente que os gastos tributários serão justificados por uma determinada finalidade do Estado. Assim, o que se deve buscar como aperfeiçoamento da sistemática de controle a benefício da transparência é a comprovação de que a renúncia foi melhor para a sociedade que o desembolso para, por exemplo, reduzir desigualdades regionais ou fomentar o pleno emprego. O que temos hoje, no Brasil, é o quanto foi renunciado, mas não o vínculo entre esse montante e resultados positivos alcançados por toda a sociedade.

Em conclusão, todo o conjunto de princípios e regras atinentes ao regime de direito público (Administração, tributação, ordem financeira e econômica) precisa ser, efetivamente, posto em prática para afastar suspeitas de ilegitimidade que avançam sobre os gastos tributários. ${ }^{35}$ A desejável participação do setor privado para a consecução de objetivos constitucionalmente previstos nas áreas sociais e econômicas, em atuação induzida pelo Estado, não pode prevalecer a qualquer custo no Estado de Direito.

\footnotetext{
${ }^{34}$ Cf. A. Lemgruber e L. Villela, O desafio de medir os gastos tributários, pp. 191-192.

${ }^{35}$ Cf. A. Elali, Incentivos fiscais internacionais, p. 110.
} 


\section{III.2. INCENTIVOS FISCAIS NO ÂMBITO DOS ACORDOS DE} BITRIBUTAÇÃO

Uma finalidade preeminente nos acordos de bitributação é evitar que os Estados de residência e fonte alcancem um mesmo contribuinte, ligado a um só fato jurídico-tributário, em um mesmo período, tributando-o duplamente. ${ }^{36}$ Todavia, não é este o único objetivo dos acordos de bitributação, uma vez que podem ser úteis instrumentos de combate à evasão fiscal. O Brasil, inclusive, costuma promulgar, por meio de decreto do Executivo convenções para evitar a dupla tributação e prevenir a evasão fiscal em matéria de impostos sobre a renda.

No âmbito do DIP, os tratados ganharam relevância enquanto fontes de direito na segunda metade do século passado, quando se sobrepuseram ao costume. Dentre as razões para essa mudança certamente encontram-se o grau de complexidade a que chegou a ordem jurídica internacional, da qual resulta a necessidade de regras cada vez mais detalhadas; a certeza e segurança jurídica conferidas em maior grau pelos acordos internacionais em relação ao costume; e as diferenças políticas e ideológicas entre Estados do Oriente, Socialistas, e do Terceiro Mundo. ${ }^{37}$

Sob a égide do direito econômico internacional, os acordos de bitributação também se prestariam a estimular os fluxos de comércio internacional, uma vez que a bitributação é um grande entrave à concretização de operações comerciais.

Ocorre que para além de evitar a bitributação, prevenir a evasão fiscal, conferir certeza e segurança jurídica e estimular o comércio internacional, os acordos de bitributação também podem ser utilizados com a finalidade de atrair IED. Neste desiderato, para além da finalidade direta sobre o capital estrangeiro, tais acordos deverão, ainda, gerar efeitos mediatos, como atração de tecnologia e know-how, geração de empregos, capacitação de mão-de-obra e outros. É sob este ângulo da indução sobre o comportamento do investidor externo que serão analisados os acordos de bitributação no bojo desta tese.

\footnotetext{
${ }^{36}$ TAVOLARO, Agostinho Toffoli. Tratados para evitar a dupla tributação internacional. In: MARTINS, Ives Gandra da Silva (coord.), Curso de direito tributário. 12. ed. São Paulo: Saraiva, 2010. p. 564.

${ }^{37}$ ENGELEN, Frank. Interpretation of tax treaties under international law, Amsterdam: IBFD, 2004, p. 19.
} 
Comumente sob a forma de arranjos bilaterais, ${ }^{38}$ acordos de bitributação permitem que os Estados de fonte e residência, por meio de recíprocas concessões, limitem suas jurisdições tributárias, eliminado ou mitigando os riscos da bitributação. ${ }^{39}$ Daí a afirmação de Claudio Sacchetto, no sentido de que os acordos de bitributação adquirem nova dimensão se vistos não como meros eliminadores da bitributação, mas instrumento de promoção de auto-suficiência dos países em desenvolvimento -PEDs ${ }^{40}$

Para bem entender a utilização dos acordos de bitributação como instrumentos de política econômica, crucial acompanhar a evolução dos principais modelos de acordo que marcaram a história do conflito fonte $\mathrm{X}$ residência:

(i) Modelo da Liga das Nações de 1928 (Londres): oriundo de estudos empreendidos por renomados economistas como Bruins (Holanda), Einaudi (Itália), Seligman (EUA) e Stamp (Grá-Bretanha), que tinha dentre seus fins avaliar os efeitos da bitributação sobre a economia, este modelo de acordo deu prioridade à residência, ou seja, aos países exportadores de capital ou países desenvolvidos - PDs; ${ }^{41}$

(ii) Modelo da Liga das Nações de 1943 (Cidade do México): ${ }^{42}$ este modelo resultou da revisão sobre o modelo original de 1928, cujo processo teve início em Haia

\footnotetext{
${ }^{38}$ Há dois acordos multilaterais de bitributação: o nórdico, firmado por Dinamarca, Finlândia,, Islândia, Noruega e Suécia; e da Caricom (Caribean Community), firmado pelos seguintes países caribenhos:Antígua e barbuda, Bahamas, Barbados, Belize, Dominica, Granada, Guiana, Jamaica, Montserrat, St Kitts e NEvis, Sta. Lucia, St. Vincent e Grenadines, Suriname e Trinidad e Tobago. Cf. A.T. Tavolaro, Tratados para evitar a dupla tributação internacional, p. 573.

39 SCHOUERI, Luís Eduardo. Tratados e convenções internacionais sobre tributação. In: COSTA, Alcides Jorge; SCHOUERI, Luís Eduardo e BONILHA, Paulo Celso Bergstrom (coord.), Direito Tributário Atual 17. São Paulo: Dialética, 2003. p. 27.

${ }^{40}$ Observa-se a definição de país em desenvolvimento e país desenvolvido é questão controversa e que exige uma rigorosa escolha de critérios classificatórios, tarefa que foge ao escopo deste trabalho. Assim sendo, com Sacchetto, entender-se-á, doravante, que desenvolvimento pode ser mensurado pela potencialidade de um país promover inovações tecnológicas, possuir matéria-prima, capitais e, sobretudo, cultura técnica. SACCHETTO, Claudio. Política de tratados em matéria tributária para países emergentes vis-à-vis países desenvolvidos e em via de desenvolvimento. In: COSTA, Alcides Jorge; SCHOUERI, Luís Eduardo e BONILHA, Paulo Celso Bergstrom (coord.), Direito Tributário Atual 23. São Paulo: Dialética, 2009. pp. 72-73. A ONU, em seus trabalhos de atualização de seu modelo de acordo de bitributação, emitiu o Relatório da $6^{a}$ sessão do Comitê dos Experts em Matéria Tributária, aos 11 de outubro de 2010, onde abordou o tema da seguintes forma: "The difficulty that arises is that the terms "developing" and "developed" is generally used to mean a preference for source-based versus residencebased taxation or capital and services importers versus exporters. Countries can and do have views on sourece versus residence basis that are not in accordance with the "developing" versus "developed" distinctions. V. http://www.un.org/esa/ffd/tax/sixthsession/UN-ModelTaxConvention.pdf.

${ }^{41}$ Cf. L.E. Schoueri, Tratados e convenções internacionais sobre tributação, p. 28.

${ }^{42}$ A Liga das Nações foi instituída pelo Tratado de Versalhes em 1919, encerrando suas atividades de facto em 1939 com a eclosão da $2^{\text {a }}$ Guerra, mas de jure somente no período 1946-1947. Cf. J.F. Rezek. Direito internacional público, p. 276.
} 
(1940) e conclusão no México, favorecendo os países em desenvolvimento ao priorizar a fonte para fins de tributação. ${ }^{43}$

(iii) Modelo da Liga das Nações de 1945 (Londres): os trabalhos de revisão do modelo original haviam sido determinados pelo Comitê Permanente para Assuntos Fiscais em sua última reunião antes do $2^{\circ}$ grande conflito. Com o fim da guerra, já na primeira reunião do Comitê realizada em Londres, este modelo foi revisto novamente agraciando os PDs por meio da prioridade da tributação na residência do titular dos rendimentos; ${ }^{44}$

(iv) Modelo OCDE de 1963 e revisões posteriores até 2010: resultado dos trabalhos iniciados em 1956 pelo Comitê Fiscal da Organização Européia de Cooperação Econômica -OECE -, esse modelo foi publicado em 1963, já pela Organização para a Cooperação e Desenvolvimento Econômico - OCDE, na qual se convertera a organização anterior. O modelo de acordo da OCDE é o mais amplamente utilizado, não apenas nas relações entre membros como naquelas entre membros e nãomembros e mesmo entre não-membros. Várias foram as revisões por que passou o Modelo OCDE, desde 1977. Em 1992, a OCDE adotou o sistema de folhas soltas para melhor atender a demanda do cenário contemporâneo, repleto de dúvidas e de novos tópicos que exigem discussão em matéria tributária. Além dessas revisões, houve ainda outras em 1994, 1995, 1997, 2000, 2003, 2005, 2008 e 2010. A OCDE é composta, basicamente, pelos países desenvolvidos, de modo que seu modelo de acordo atende, em primeiro lugar, aos interesses do Estado de residência. Ilustra tal conclusão, o direito exclusivo de tributar os lucros de uma empresa pelo Estado de residência. ${ }^{45}$ Trata-se, segundo Alberto Xavier, da competência exclusiva primária do Estado da residência (shall only be taxed). ${ }^{46}$

(v) Modelo ONU de 1980 e 2001: ${ }^{47}$ A ONU retomou os trabalhos da Liga das Nações, porém os interrompeu em 1954 somente a eles retornando em 1967. Motivou o

\footnotetext{
${ }^{43}$ Cf. L.E. Schoueri, Tratados e convenções internacionais sobre tributação, p. 28

${ }^{44}$ Cf. A.T. Tavolaro, Tratados para evitar a dupla tributação internacional, p. 575; L.E. Schoueri, Tratados e convenções internacionais sobre tributação, p. 28.

${ }^{45}$ É certo que há mitigação dessa regra caso haja um estabelecimento permanente atuando na fonte.

${ }^{46}$ Cf. A. Xavier, Direito tributário internacional do Brasil, p. 669.

47 A Organização das Nações Unidas resultou dos encontros de Dumbarton Oaks (1944) e de Yalta (1945), além de San Francisco (1945), donde se lavrou sua Carta Constitutiva. Hoje a ONU conta com
} 
retorno o objetivo de facilitar a conclusão de convenções físcais entre países desenvolvidos e em desenvolvimento, protegendo-se as receitas fiscais de ambos os grupos de países, chegando-se, em 1980, ao Modelo ONU. De fato, esperava-se que o Modelo ONU trouxesse maior equilíbrio às relações entre PED e PD; contudo, demasiadamente alicerçado no Modelo OCDE, uma vez mais consagrou-se a preponderância da residência, malgrado tenha efetuado algumas concessões à fonte. Apresenta algumas diferenças do Modelo OCDE, como o tratamento dos EPs, cuja presença mínima da atuação estrangeira foi reduzida, antecipando a jurisdição da fonte; e a retenção na fonte (withholding tax) mais elevada sobre dividendos e royalties. ${ }^{48}$

Doernberg, porém entende o contrário, pois o Modelo OCDE e o Modelo EUA favorecem países de exportação de capital, o Modelo ONU teria favorecido os países importadores de capital, concedendo-lhes maior autoridade para tributar renda passiva e ativa. $^{49}$

(vi) Modelo Grupo Andino: prioriza a fonte, atendendo aos interesses de PED. Trata-se de modelo contrário, pois, ao Modelo OCDE. ${ }^{50}$ Elaborado pelos membros do Pacto Andino (Bolívia, Chile, Colômbia, Equador, Peru e Venezuela) em 1971, o Modelo Andino apresenta-se bastante peculiar, regrando apenas sobre conexão territorial ( fonte do rendimento), prescindindo da conexão pessoal. Restrito a Estados próximos não apenas geograficamente, como também do ponto de vista econômico e político, o Modelo Andino mais se assemelha a uma declaração de princípios que podem ser utilizados em negociações com outros Estados que adotam a conexão pessoal e a tributação universal. ${ }^{51}$

(vii) Modelo dos EUA: com mais de 50 acordos de bitributação firmados, os EUA figuram na ordem internacional como o maior parceiro de operações comerciais do globo, marcando constante presença no fluxo de investimentos internacionais. Dada a relevância com que tradicionalmente cuidam dos assuntos inerentes à tributação internacional, os EUA trataram de elaborar seu próprio Modelo em 1977, revisando-o

mais de 190 adesões, abrangendo todas as soberanias formais do mundo contemporâneo. Cf. J.F. Rezek. Direito internacional público, pp. 276-277.

${ }^{48}$ Cf. C. Sacchetto. Política de tratados em matéria tributária para países emergentes vis-à-vis países desenvolvidos e em via de desenvolvimento, p.77.

${ }^{49} \mathrm{Cf}$. R. Doernberg, International Taxation in a nutshell, p. 111.

${ }^{50}$ Cf. L.E. Schoueri, Tratados e convenções internacionais sobre tributação, p. 29.

${ }^{51}$ Cf. H. T. Tôrres, Pluritributação internacional sobre as rendas de empresas, p. 551. 
em 1981, 1996 e 2006. ${ }^{52}$ Doernberg explica que a política para celebração de acordos dos EUA tem dois objetivos principais: harmonizar suas regras domésticas com as regras domésticas de outros Estados e preservar a jurisdição sobre cidadãos e residentes. O Modelo EUA é parecido com o modelo OCDE, embora se possam apontar algumas distinções entre eles: (i) o Modelo EUA permite a tributação com base na cidadania, de modo que será possível alcançar cidadãos de um Estado contratante ainda que resida no outro Estado contratante; (ii) residência de empresas será o local de sua incorporação para o Modelo EUA; já para o Modelo OCDE, o local de sua direção efetiva; (iii) O Modelo EUA combate a bitributação por meio do método da imputação, concedendo um crédito pelo imposto pago na fonte; o Modelo OCDE admite, além da imputação, o método da isenção para o mesmo fim; (iv) para o Modelo EUA, os juros somente serão tributados na residência do recebedor - competência exclusiva -, enquanto o Modelo OCDE prevê competência cumulativa, embora limitada na fonte; ${ }^{.3}$ (v) o Modelo EUA é mais rigoroso quanto ao reconhecimento dos benefícios trazidos pelo acordo. Para se beneficiar da redução ou eliminação da retenção na fonte sobre dividendos, royalties ou juros de fontes norte-americanas é preciso ser residente do outro Estado contratante. A fim de evitar, portanto, que residentes de terceiros países se beneficiem dos acordos de bitributação, o Modelo EUA traz, em seu artigo 22, limitações de benefícios (limitations on benefits - LOB), cujo propósito é a tentativa de afastar a subjetividade em reconhecer uma pessoa como residente do outro Estado contratante. ${ }^{54}$

Como se percebe, os acordos de bitributação sempre refletiram, em sua estrutura e técnica, a diferença entre países exportadores de capital e países importadores de capital. A dicotomia fonte (PEDs) X residência (PDs) é uma das causas principais da bitributação e está consagrada nos dois principais modelos de acordo: ONU e OCDE. ${ }^{55}$ Pode-se, portanto, concluir que cada Estado deve construir sua política de implementação de acordos de bitributação, conforme suas características, interesses e

\footnotetext{
${ }^{52}$ Cf. A.T. Tavolaro, Tratados para evitar a dupla tributação internacional, p. 576.

${ }^{53}$ Cf. R. Doernberg, International Taxation in a nutshell, pp. 110-111.

${ }^{54}$ Segundo a Explicação Técnica do Modelo EUA emitida pelas autoridades fazendárias daquele País, o artigo 22 não se baseia na determinação do propósito ou intenção, mas, ao contrário, impõe uma série de testes objetivos, de modo que um residente de um Estado contratante que satisfaça um desses testes receberá os benefícios do acordo independente de suas razões para ter escolhido determinada estrutura de negócios. (tradução livre). Cf. BITTKER, Boris; LOKKEN, Lawrence. Fundamentals of international taxation. NY: WG\&L RIA, 2008/2009, p.67-48 e p. 67-77.

${ }_{55}$ Cf. C. Sacchetto. Política de tratados em matéria tributária para países emergentes vis-à-vis países desenvolvidos e em via de desenvolvimento, p.76.
} 
necessidades, uma vez que os acordos, efetivamente, podem ser eficaz instrumento de garantia das normas tributárias indutoras.

A construção de uma política de negociação de tratados deve ser bem planejada a fim de conduzir aos resultados esperados. Naturalmente que uma extensa rede de acordos confere maiores possibilidades de comércio e investimentos internacionais, porém, uma cuidadosa política de acordos tributários (treaty tax policy) exige um estudo mais aprofundado do cenário internacional e das medidas adotadas pelos interlocutores. De fato, em uma economia global, como já dito alhures, não há a chance de ter êxito no cenário externo sem conhecer o impacto das medidas alheias na própria jurisdição como em outras; assim como o impacto das medidas domésticas nas diversas jurisdições.

Historicamente, uma das formas de negociação utilizadas pelos países de fonte prioriza as cláusulas de incentivo como tax sparing ou matching credit, matéria que justifica exame mais detido no item subseqüente.

III.2.1. Cláusulas de incentivo

\section{III.2.1.1 Tax sparing e matching credit}

Regra geral, pelo mecanismo da imputação, os acordos procuram manter a neutralidade do investimento quanto à tributação. Compensa-se, por meio de um crédito concedido na residência, o montante de imposto recolhido à fonte. Ocorre que por meio das cláusulas de incentivo, a residência deverá manter o crédito mesmo em face do não recolhimento à fonte. Trata-se, pois, de medida deveras atrativa ao investidor estrangeiro, razão pela qual se consagrou como prática de países em desenvolvimento interessados em atrair IED.

Assim, os mecanismos de tax sparing e matching credit são utilizados como cláusulas constantes dos acordos de bitributação que visam a garantir a eficácia das normas tributárias indutoras concedidas pelo Estado-fonte. ${ }^{56}$

\footnotetext{
${ }^{56}$ Reconhece-se a celeuma em torno da definição exata dos termos tax sparing e matching credit. Entretanto, uma mais detida análise sobre o tema foge ao escopo deste trabalho. Com efeito, casos em que haja acordo fixando previamente uma alíquota para efeito de concessão de crédito (matching credit) poderão ser difíceis de classificar, caso não haja qualquer recolhimento do imposto na fonte (tax sparing). Como esta, outras situações podem gerar dúvidas sobre as cláusulas em questão. Poder-se-ia classificar o
} 
O tax sparing encontra a mesma semântica em termos diversos como crédito fictício, shadowing tax, phantom tax ou notional tax e se caracteriza por apresentar grande diversidade de opiniões a seu respeito. ${ }^{57}$ Por seu intermédio, deverá haver a manutenção do crédito na residência com base no imposto que teria sido pago na fonte, não fosse o incentivo fiscal concedido por esta última.

Já o matching credit, também é conhecido como crédito presumido ou préfixado ou lump-sum tax credit. Neste caso, tem-se uma alíquota pré-determinada nos acordos de bitributação como referência para o crédito a ser concedido ao residente, mais elevada que a alíquota vigente na fonte, baixa em virtude de indução. Segundo Heleno Tôrres, "sua utilização é sempre definida por cada categoria de renda, sendo mais freqüente quanto à tributação de dividendos, mas se aplica também aos juros e royalties." $" 58$

Tavolaro assinala que os termos são tratados, por vezes, como sinônimos, prevalecendo a designação de tax sparing. ${ }^{59}$ Neste sentido, a própria OCDE em seu Relatório intitulado Tax Sparing: a Reconsideration (1998), vale-se do termo tax sparing sem referir-se, explicitamente, ao matching credit.

Tome-se o exemplo de um investidor do País "A" que aufira rendimento de \$100 no País "B". Tais rendimentos seriam tributados em "B" a uma alíquota de $15 \%$, gerando um imposto de \$15 e, conseguintemente, o País "A" concederia ao investidor um crédito de imposto de $\$ 15$. Ocorre que o País “B”, por meio de normas tributárias indutoras, resolve conceder um tratamento mais benéfico ao investidor estrangeiro conforme uma das possibilidades a seguir:

(i) concede tax holidays ao adventício de modo que o imposto em "B" seja zero. Neste caso, se houver a previsão do tax sparing, “A” deverá manter o crédito de $\$ 15$; ou (ii) reduz sua alíquota interna para $5 \%$ para investidores externos. Nesta hipótese, caso tenha sido convencionada a cláusula de matching credit a 15\%, o País "A" deverá manter o crédito de $\$ 15$.

\footnotetext{
tax sparing como gênero do qual seriam espécies o tax sparing stricto sensu e o matching credit. No entanto, aqui será adotado o termo cláusulas de incentivo como suficiente para abranger os institutos do tax sparing e do matching credit.

57 TAVOLARO, Agostinho Toffoli. Tratado Brasil/Estados Unidos para evitar a dupla tributação. In: Filho, C.P.; Tonani, F.; Behrndt M.A.; Ribeiro, R.P; Vasconcellos, R.F. (coord.), Revista de direito tributário internacional. Ano 5, nº 15, São Paulo: Quartier Latin, 2010.

${ }^{58}$ Cf. H. T. Tôrres, Pluritributação internacional sobre as rendas de empresas, p. 469.

${ }^{59}$ Cf. A. T. Tavolaro, Tratado Brasil/Estados Unidos para evitar a dupla tributação, p. 38.
} 
Nos dias atuais, está cada vez mais difícil garantir a manutenção do crédito pela via das cláusulas de incentivo, pois há uma renúncia de receitas na residência que acaba por custear a política de indução praticada pela fonte. Uma maior preocupação com as receitas públicas tem levado países desenvolvidos a renegociar acordos dispondo sobre essas cláusulas. Exemplo disso são a Alemanha (acordo denunciado em 2005), Holanda e os países nórdicos que já sinalizaram neste sentido com o fisco brasileiro. ${ }^{60}$

A controvérsia sobre tax sparing já dura mais de meio século, encontrando sua gênese nas discussões levadas a efeito no Reino Unido, que culminaram com o Relatório da British Royal Commission, em 1953. Havia o interesse britânico em estimular seu investidor a atuar no exterior por meio da política tributária, razão pela qual a Comissão recomendou a adoção do tax sparing. O Parlamento britânico analisou a proposta em 1953 e 1956, mas ela acabou sendo rejeitada, em 1957, pelo Chancellor of the Exchequer. ${ }^{61}$ Tal veto, contudo, não encerrou a discussão sobre o tema, que retornou, em 1961, por meio de previsão legal que autorizou o tax sparing para promoção do investimento em países em desenvolvimento. ${ }^{62}$

Inobstante a primazia britânica na abordagem do tema, o primeiro acordo contendo cláusula de tax sparing foi negociado entre EUA e Paquistão, em 1957. Este tratado representa um marco quanto à política de negociação de acordos de bitributação pelos EUA, já que o Senado rejeitou o texto de modo que definiu, dali por diante, a franca oposição norte-americana ao tax sparing. Com efeito, nenhum dos acordos firmados pelos EUA contempla tal cláusula de incentivo. ${ }^{63}$

A justificativa para tanto reside no fato de os EUA conceberem o tax sparing como um mecanismo contrário à neutralidade. Além de estimular o investidor residente a atuar no exterior, haveria um tratamento menos favorável ao investidor residente no outro signatário do acordo do que ao investidor norte-americano, o que seria vedado pela não-discriminação. Os acordos celebrados pelos EUA não poderão contemplar menores benefícios aos não-residentes do que o previsto para seus residentes pela ordem interna ou pelas próprias convenções. ${ }^{64}$

\footnotetext{
${ }^{60}$ Cf. A. T. Tavolaro, Tratado Brasil/Estados Unidos para evitar a dupla tributação, p. 39.

${ }^{61}$ Compara-se ao Ministro da Fazenda. Maiores informações em http://www.hm-treasury.gov.uk.

${ }^{62}$ OCDE. Tax sparing: a reconsideration, p. 15.

63 OCDE. Tax sparing: a reconsideration, p. 16. Tavolaro descreve o papel proeminente de Stanley Surrey ao discursar no Senado em sentido contrário à adoção do tax sparing. Para o Professor da Harvard, a inclusão tornar-se-ia obrigatória em todos os acordos firmados com países em desenvolvimento. Cf. A. T. Tavolaro, Tratado Brasil/Estados Unidos para evitar a dupla tributação, p. 40.

${ }^{64}$ Cf. A. T. Tavolaro, Tratado Brasil/Estados Unidos para evitar a dupla tributação, p. 12.
} 
A rejeição do tax sparing pelos EUA foi negligenciada por outros países desenvolvidos, pois durante os anos 60 e 70 a inclusão desta cláusula de incentivo aumentou significativamente nos mais diversos acordos de bitributação. ${ }^{65}$

Tendo sido concebidas como forma de atração dos IED, as cláusulas de incentivo foram testadas em situações diametralmente opostas por James Hines, ao comparar os efeitos do tax sparing sobre o comportamento dos investidores norteamericanos - já que os EUA não assinam acordos com tax sparing em nenhuma hipótese - e o Japão, que foi um dos países desenvolvidos mais afeitos ao tax sparing em seus acordos com PED desde os anos $60 .{ }^{66}$ Em suas ilações, Hines afirma: ${ }^{67}$

"The results indicate that "tax sparing" is effective in stimulating IED. Japanese firms locate a much higher fraction of their foreign investment in countries with whom Japan has "tax sparing" agreements than do American firms. Furthermore, host governments appear to grant Japanese firms significant tax reductions that are not available to their American counterparts. All other things equal, "tax sparing" agreements are associated with 140\%-240\% higher IED levels and $23 \%$ lower tax rates on FDI."

Não está isenta de críticas a posição de Hines, cuja base de pesquisa abrangeu apenas dois países. Divergindo dessas conclusões, diversos PD resistem em firmar acordos com o tax sparing, ao julgá-lo oportuno para concorrência tributária nociva; complexo para ser fiscalizado e ineficaz na promoção de desenvolvimento econômico. ${ }^{68}$ Reforçando a posição adversa encontra-se a OCDE, que em seu Tax Sparing: $a$ Reconsideration (1998) concluiu pela ineficiência do tax sparing em atrair IED, como se verá a seguir.

\section{III.2.1.2. Tax Sparing: uma reconsideração}

Em seu primeiro Modelo de Convenção, datado de 1963, a OCDE não adotou posição expressamente favorável ao tax sparing. Todavia, em seus comentários ao artigo 23, tratou-o como possível em alguns casos, nos quais os PD poderiam considerar

\footnotetext{
${ }^{65}$ OCDE. Tax sparing: a reconsideration, p. 16.

${ }^{66}$ HINES Jr., James R. Tax sparing and direct investment in developing countries. NBER - National Bureau of Economic Research, Working Paper n. 6728/2000, p. 3. Disponível em: http://www.nber.org/papers/w6728.pdf?new_window=1. Acesso em 07 out 2011.

${ }^{67}$ Cf. J.R. Hines Jr, Tax sparing and direct investment in developing countries, p. 3.

${ }^{68}$ Cf. H. T. Tôrres, Pluritributação internacional sobre as rendas de empresas, p. 468.
} 
a isenção ou a imputação pelo imposto que deveria ser pago no PED, não fossem os incentivos fiscais. ${ }^{69}$

Em seu Modelo de 1977, persistiu a omissão da OCDE quanto ao assunto, exceto pelos comentários que mantiveram o status alternativo ao tax sparing. Destacase, porém, que tais comentários foram aprofundados para conformar as recomendações da OCDE com a prática que já se manifestava nos acordos de então. ${ }^{70}$ Basicamente, a OCDE preconizava, ao Estado de residência, a isenção ou a imputação ou, ainda, a concessão de crédito superior ao imposto na fonte. Além disso, propunha a limitação temporal ou do montante do crédito, a fim de evitar exageros por parte da fonte. ${ }^{71}$

Malgrado a omissão de uma cláusula de incentivo no Modelo da OCDE, os PD aumentaram consideravelmente o número de acordos com tax sparing até o final dos anos 90. Assim foi com o Canadá, que assinou 36 acordos garantindo as normas indutoras na fonte entre 1966 e 1999. Do mesmo modo a Austrália, que assinou 14 entre 1967 e $1999 .{ }^{72}$ Deve-se considerar que diversos países desenvolvidos podem não ter negociado acordos com tax sparing por terem mantido um sistema de isenção sobre as rendas obtidas no exterior, o que seria suficiente para não interferir na política de indução dos países em desenvolvimento. ${ }^{73}$

À expansão dos acordos contendo cláusulas tax sparing seguiu-se certo desinteresse, por parte de alguns países, causado pela publicação do Relatório da OCDE de 1998, intitulado Tax Sparing: a Reconsideration. ${ }^{74}$ Sob o argumento que o cenário

\footnotetext{
${ }^{69}$ BROOKS, Kimberley. Using the tax system to promote investment in low-income countries: an illustration of good intentions, bad results. In: Globalization and the impact of tax on international investments: a symposium in honor of the late Alex Eason. Queen's University, Faculty of Law. Feb. 2008,p.12. Disponível em: http://law.queensu.ca/events/recentConferences/eassonSymposiumDratPapers/kimBrooksTaxSparingFeb 242008.doc. Acesso em 07 out 2011.

${ }^{70}$ Os acordos Alemanha-Indonésia (1976) e Brasil-Japão (1977) já contemplavam uma alíquota fixa para o crédito correspondente ao imposto tido por recolhido na fonte. A limitação temporal das cláusulas de incentivo, por seu turno, poderiam ser vistas no acordo Reino Unido-Indonésia (1974) e no SuéciaFilipinas (1966) - as chamadas sunset clauses, que fazem expirar o tax sparing depois de dado lapso temporal. V. OCDE. Tax sparing: a reconsideration, pp. 16-17.

${ }^{71} \mathrm{Cf}$. K. Brooks, Using the tax system to promote investment in low-income countries: an illustration of good intentions, bad results, p. 13.

${ }^{72} \mathrm{Cf}$. K. Brooks, Using the tax system to promote investment in low-income countries: an illustration of good intentions, bad results, p. 13-14.

${ }^{3} \mathrm{Cf}$. K. Brooks, Using the tax system to promote investment in low-income countries: an illustration of good intentions, bad results, p. 13.

${ }^{74}$ Após esse Relatório, mesmo países motivados com o tax sparing como o Canadá, a Austrália e o Reino Unido praticamente não mais assinaram acordos contendo cláusula de incentivo. Cf. K. Brooks, Using the tax system to promote investment in low-income countries: an illustration of good intentions, bad results, p. 18 .
} 
internacional havia se modificado, a OCDE questionou a eficácia do tax sparing quanto à atração do IED, com base nos seguintes tópicos: ${ }^{75}$

(i) custos e ganhos: a OCDE põe sob suspeita a eficiência dos incentivos fiscais, pois que a eles corresponde a renúncia de receitas;

(ii) meta: difícil garantir que os agentes a quem se pretende induzir determinado comportamento, sejam, de fato, os beneficiados. Pode-se atingir universo mais restrito ou mais amplo do que se pretendia. É o caso do residente na fonte que constitui uma subsidiária no outro Estado contratante a fim de se beneficiar dos incentivos fiscais;

(iii) complexidade: as normas tributárias indutoras devem se caracterizar pela precisão, conferindo segurança e clareza aos investidores;

(iv) concorrência tributária: incentivos fiscais podem fomentar a concorrência nociva entre Estados;

(v) fatores não tributários $\mathrm{X}$ fatores tributários: a decisão de alocação do investimento seria pouco ou nada influenciada pela tributação. Há que se considerar os outros fatores econômicos, políticos e sociais que estimulam o investimento;

(vi) lobbying: a concessão para determinado setor estimula o pleito para diversos outros setores da economia.

Embora não tenha condenado a prática do tax sparing, a OCDE recomendou maior precaução em sua adoção. Talvez a globalização, em reduzindo as barreiras ao comércio e ao investimento, ao mesmo tempo em que fomentando operações transfronteiriças, tenha tornado o Estado da residência mais sensível aos efeitos do tax sparing. ${ }^{76}$ Seria dizer, a renúncia de receitas em um cenário crescentemente competitivo prejudicaria o Estado de residência. Além disso, a fonte possivelmente já não precisaria priorizar a atração do IED pelo veículo tax sparing, em face da também crescente mobilidade do capital.

Independente da consistência das proposições da OCDE, fato é que seus argumentos reduziram a adoção de cláusulas de tax sparing por parte dos países desenvolvidos.

\section{III.2.1.3 Tax Sparing: reconsideração da reconsideração}

\footnotetext{
${ }^{75}$ OCDE. Tax sparing: a reconsideration, pp. 25-28.

${ }^{76}$ OCDE. Tax sparing: a reconsideration, $\mathrm{p} 21$.
} 
Desde que surgiu, ainda no contex to britânico, o tax sparing tem dado ensejo às mais amplas divergências quanto à sua utilidade para PD e PED. Destarte, os resultados alcançados pelo Relatório da OCDE (1998), que preconizam uma reconsideração sobre o instituto do tax sparing em função da perda de sua utilidade, não podem ser tidos por definitivos.

Neste giro, Luís Eduardo Schoueri apresenta original estudo sobre o tema, sugerindo uma reconsideração da posição da OCDE, gravada em seu Relatório 1998 sobre tax sparing. Em síntese, Schoueri rebate os argumentos da OCDE nos seguintes moldes: ${ }^{77}$

(i) OCDE alega mudanças na estrutura econômica global quando compara os dias atuais àqueles da época da adoção das primeiras cláusulas tax sparing, para então sustentar que tax sparing não é meio eficaz de promoção do investimento ou do desenvolvimento econômico. Em sentido oposto, não há evidência empírica de maus resultados pelo uso do tax sparing, ao contrário, a continuidade de sua utilização na política de acordos tributários dos países sugere efeitos positivos. Ademais, a OECD não deixa claro quem estaria habilitado a avaliar a qualidade dos resultados;

(ii) Efeito carona -free-rider- seria outra razão para reconsiderar o tax sparing, já que, segundo a OCDE, os investidores estrangeiros seriam pouco ou nada influenciados por razoes tributárias, mas por outras de natureza econômica, política ou social. Se assim fora, não se poderia nem mesmo avaliar o papel dos acordos de bitributação na atração do IED. Cita o exemplo dos investimentos alemães no Brasil quando comparados cinco anos antes da revogação do acordo Brasil-Alemanha e cinco anos após, para concluir que aumentaram independente do acordo. Isso não autoriza a conclusão de que os acordos seriam prejudiciais ao investimento. Conclui-se que esta análise, para ser confiável, necessita de outras variáveis merecendo ser desconsiderada;

(iii) A OCDE alega que haveria uma preocupação dos PED quanto ao alto preço do tax sparing, afinal, os PD para negociá-lo exigiriam baixa tributação na fonte como condição. Ocorre que, historicamente, a OCDE sempre priorizou a tributação na residência em detrimento da fonte. Logo, a baixa tributação da fonte sempre foi uma posição da OCDE com pequenas ressalvas ligadas à concorrência nociva. Para que este

${ }^{77}$ SCHOUERI, Luís Eduardo. Tax sparing: reconsideração da reconsideração. In: OLIVEIRA, Ricardo Mariz; SCHOUERI, Luís Eduardo; ZILVETI, Fernando Aurélio (coord.), Direito Tributário Atual 26. São Paulo: Dialética, 2011. pp. 98-101. 
argumento fosse mais convincente seria crucial que a OCDE revisse sua posição quanto à tributação da fonte;

(iv) $\mathrm{O}$ aumento do padrão de vida nos PED ensejaria reconsideração sobre tax sparing. Mas tal crescimento não pode ser tido como uniforme por todos os países em desenvolvimento. As desigualdades permanecem, de modo que não há justificativa para reconsiderar o tax sparing.

(v) Cláusulas de incentivo teriam alto potencial para abuso e seriam ineficazes na promoção do desenvolvimento. Alega-se, por oposto, que nenhum dispositivo dos acordos sobreviveria a este argumento, uma vez que todos apresentam o mesmo potencial para tanto. Seria mais prudente discutir mecanismos para evitar o abuso dos tratados, como cláusulas de limitação dos benefícios - LOB. O simples argumento de abuso potencial não é sólido o suficiente para refutar a adoção de uma dada cláusula.

Em linhas gerais, a reconsideração proposta pela OCDE tem por base o conceito de tax sparing como mecanismo de assistência dos PD para os PED, além do fato de que o tax sparing afeta a neutralidade fiscal.

Segundo Schoueri, uma reconsideração da reconsideração da OCDE deve ter por amparo o seguinte: ${ }^{78}$ (i) a neutralidade de exportação de capital ${ }^{79}$ não é o único objetivo da tributação internacional; (ii) o tax sparing não é um mero favor concedido pelo Estado-residência; e (iii), por fim, uma isenção eventualmente concedida pela residência não confere maiores prerrogativas à fonte.

$\mathrm{O}$ argumento da NEC seria falacioso, pois o funcionamento eficiente do método do crédito neutralizaria a carga tributária e impactaria a decisão dos investidores favoravelmente aos países mais bem equipados quanto aos demais fatores de atração do IED. Em outras palavras, havendo o mesmo ônus tributário ao investidor se atuar em sua jurisdição ou no exterior, certamente ele ficará em sua jurisdição. Economicamente haveria uma série de riscos que se revertem em custos. Do ponto de vista jurídico, cabe observar que se trata de deixar o Estado de residência, para investir na fonte, onde, certamente, haverá uma diferença na infra-estrutura pelo mesmo tributo pago. Ou seja, os benefícios concedidos pela residência seriam maiores que pela fonte, em correspondência ao mesmo ônus tributário.

\footnotetext{
${ }^{78}$ Cf. L.E. Schoueri. Tax sparing: a reconsideração da reconsideração, p.103.

${ }^{79}$ A NEC geralmente corresponde à prática perseguida pelos Estados que adotam a tributação universal e o método da imputação (crédito) para combater a bitributação. Já a NIC - neutralidade de importação de capital - é utilizada pelos países que adotam territorialidade e isenção como método de combate á bitributação.
} 
Ademais, se a residência realmente cresse na NEC, deveria reembolsar os contribuintes sempre que o imposto na fonte fosse maior que o seu (diferença negativa) e não somente tributar a situação inversa, quando seu imposto supera o da fonte (diferença positiva). ${ }^{80}$ Seria o mesmo que trabalhar com o crédito integral (full credit), restituindo totalmente o imposto pago na fonte, ao invés de adotar o mecanismo do crédito limitado, em que se limita o crédito do imposto à alíquota praticada na residência. Com efeito, a neutralidade seria ainda mais respeitada com a adoção do crédito integral, pois o investidor seria sempre sujeito à tributação correspondente à alíquota da residência independente da jurisdição em que desejar investir. Se optar por uma de tributação mais baixa, pagará a diferença na fonte, de modo que o montante seja exatamente o mesmo que suportaria se tivesse mantido seu investimento na residência. Caso a opção seja por uma jurisdição mais onerosa, a restituição do excesso entre a tributação na fonte e na residência irá produzir tributação equivalente à da residência, mas já recolhida aos cofres da fonte.

A comparação entre os efeitos dos métodos de crédito limitado e integral quanto à NEC pode ser assim exemplificada:

- Método do crédito Limitado (OCDE) - Situação I

\begin{tabular}{lr|r} 
Residência: alíquota 30\% & $\begin{array}{r}\text { crédito \$20 } \\
\text { Imposto \$10 }(100 \times 30 \%)-20\end{array}$ \\
\hline Fonte: alíquota 20\% & rendimento \$100 & Imposto \$20 (100X20\%)
\end{tabular}

Neste caso, a residência cobra os \$10 de diferença entre sua imposição e a da fonte. Ao final, o investidor pagaria \$30 (\$20 na fonte e \$10 na residência), o que não afeta sua decisão de investir, sob o ponto de vista tributário, em sua jurisdição ou no exterior.

- Método do crédito Limitado (OCDE) - Situação II

\footnotetext{
${ }^{80}$ Cf. L.E. Schoueri. Tax sparing: a reconsideração da reconsideração, p.104.
} 


\begin{tabular}{|c|c|c|}
\hline \multirow{3}{*}{\multicolumn{2}{|c|}{ Residência: alíquota $30 \%$}} & crédito $\$ 30$ \\
\hline & & Imposto $\$ 0 \quad(100 \times 30 \%)-30$ \\
\hline & & Restituição \$0 \\
\hline Fonte: alíquota $40 \%$ & rendimento $\$ 100$ & \\
\hline & & Imposto $\$ 40 \quad(100 X 40 \%)$ \\
\hline
\end{tabular}

Como a alíquota na fonte supera a da residência, o crédito estará limitado ao quantum tributado na última (30\%). Assim, o total do crédito não superará $\$ 30$ a despeito de ter havido a tributação em $\$ 40$ na fonte. Como se vê, o investidor não se sujeita, ao final, ao montante tributado na residência, mas ao total da jurisdição em que decidir investir.

- Método do crédito integral (full credit) - Situação I

\begin{tabular}{lrl} 
Residência: alíquota 30\% & $\begin{array}{r}\text { crédito \$20 } \\
\text { Imposto \$10 }\end{array}$ & $(100 \times 30 \%)-20$ \\
\hline Fonte: alíquota $20 \%$ & rendimento \$100 & \\
& & Imposto \$20 (100X20\%)
\end{tabular}

Uma vez que a residência confere o crédito integralmente correspondente ao imposto pago na fonte, não haveria influência sobre a alocação do investimento.

- Método do crédito integral (full credit) - Situação II

Residência: alíquota 30\%

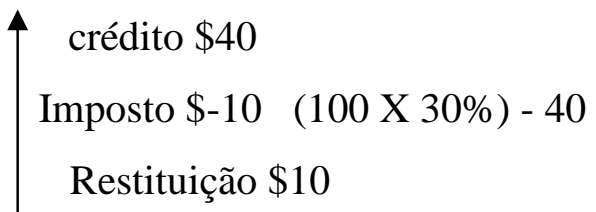


O imposto na residência seria negativo, já que o crédito corresponderia ao imposto na fonte (\$40). Nesta situação, deve haver a restituição de \$10 ao investidor, pois que na situação inversa houve a cobrança pela diferença positiva entre a imposição na residência e na fonte. Sob o aspecto da neutralidade de exportação de capital, o investidor seria, ao final, tributado em \$30 (\$40 na fonte - \$10 de restituição na residência), ou seja, o mesmo ônus imposto pela residência. O respeito à neutralidade neste caso é maior do que no crédito limitado (OCDE), uma vez que o investidor sofrerá a mesma tributação independente de onde decidir investir. Não apenas em sua própria jurisdição, mas em qualquer outra, seja de baixa ou elevada tributação, o que representa, sem dúvidas, um ganho no aspecto da neutralidade.

Em seu segundo argumento, Schoueri defende que o tax sparing não seja visto como concessão do país desenvolvido para o país em desenvolvimento. Em sua visão, poderá haver o uso do mecanismo mesmo em tratados celebrados entre PD. Seria isso um passo adiante no reconhecimento do exercício da jurisdição, pois sem o tax sparing, haveria um desrespeito pela soberania da fonte, já que ao optar por uma política indutora, veria a residência exercer sua jurisdição sobre a renda que resolvera não tributar. Em sua teorização, o Professor das Arcadas asserta que: ${ }^{81}$

(i) basta considerar que os acordos de bitributação repartem o poder de tributar entre duas jurisdições para reconhecer que o tax sparing não é um favor concedido pela residência;

(ii) quando um signatário firma um acordo, está concordando em restringir sua própria jurisdição e reconhecendo que o outro signatário também a possui sobre um mesmo evento, afinal acordos resultam da legitimidade simultânea de dois Estados para tributar um mesmo fato ligado a um mesmo contribuinte;

(iii) determinado rendimento está sujeito à tributação na fonte até um teto, a partir do qual se inicia a jurisdição da residência. Portanto, este rendimento estaria sujeito a duas jurisdições, mas ambas repartiram (e limitaram) a competência para

\footnotetext{
${ }^{81}$ Cf. L.E. Schoueri. Tax sparing: a reconsideração da reconsideração, pp. 105-106.
} 
tributar. Logo, uma jurisdição não estaria autorizada a tributar além de seus limites. Do contrário, alcançaria um rendimento que pelo acordo fora conferido à outra jurisdição;

(iv) o mecanismo do crédito somente funciona para repartir as jurisdições se a fonte exercitar seu poder de tributar de modo positivo, ou seja, se tributar completamente o rendimento que lhe foi conferido pelo acordo. Caso a fonte decida exercitar seu poder de tributar de forma negativa, não tributando o rendimento em questão, o Estado-residência reivindica seu direito de tributá-lo;

(v) a repartição de competência antes aceita pelos contratantes parece não ser respeitada pela residência, que não reconhece o direito do outro signatário exercer, integralmente, sua jurisdição sobre o quanto lhe foi reservado;

(vi) assim o tax sparing e o matching credit seriam mecanismos de correção dessa distorção, já que, por meio deles, o Estado-residência reconheceria o direito de a fonte exercer sua jurisdição de forma positiva ou negativa. Por esta razão, não poderiam ser vistos como favor da residência, mas como a confirmação de que a residência reconhece não possuir jurisdição alguma sobre o rendimento que foi conferido ao Estado-fonte.

O terceiro argumento pela reconsideração da visão da OCDE sobre tax sparing sustenta que o Estado-fonte geralmente convenciona tributar não-residentes de forma mais branda que o faria na ausência do acordo. Na prática, há uma limitação do poder de tributar da fonte, a partir da qual o acordo confere um poder de tributar residual ao Estado-residência. A grande questão é saber - na ordem inversa ao tax sparing- se a residência isentasse determinado rendimento cairia o limite do exercício da jurisdição da fonte? ${ }^{82}$

Alegam os detratores do tax sparing que não se deve conceder crédito em situações que não há risco de bitributação. Ora, na ordem inversa das coisas, isto é, em não havendo tributação pela residência, também não haveria o risco da dupla imposição, mas não é prática corrente reconhecer à fonte o direito de adentrar ao espaço convencionado para a residência. ${ }^{83}$

Um Estado que não negocia o tax sparing deveria reconhecer a impossibilidade de a residência isentar determinado rendimento sob pena de, sobre este, incidir

\footnotetext{
${ }^{82}$ Cf. L.E. Schoueri. Tax sparing: a reconsideração da reconsideração, p. 107.

${ }^{83}$ Cf. L.E. Schoueri. Tax sparing: a reconsideração da reconsideração, p. 107.
} 
integralmente a jurisdição da fonte. Seria o poder de tributar residual da fonte, tal qual existe nos acordos em vigor favoravelmente à residência. ${ }^{84}$

III.2.2 Deve a residência reconhecer os incentivos da fonte?

Conquanto não se pretenda encerrar a discussão sobre cláusulas de incentivo, a teoria de Schoueri abre novo flanco para o registro de impressões acerca do tema. Sabendo-se que a bitributação representa um grande entrave ao IED, natural que os Estados cujas políticas macroeconômicas estejam voltadas para a atração do capital, priorizem a inserção do tax sparing em seus acordos de bitributação.

A política oposta, da qual se retira o exemplo extremo dos EUA, encontra arrimo no fato de que acordos de bitributação não devem restringir o escopo da tributação universal no Estado de residência mais do que o necessário para evitar a dupla tributação. Sob esta óptica, a manutenção do crédito para compensar impostos que não foram recolhidos na fonte é discriminatória em favor desta última, já que influiria sobre a decisão do investidor com mais ênfase que a residência. ${ }^{85}$

Para os EUA, o crédito do imposto estrangeiro - foreign tax credit -seria um alívio à bitributação quando o rendimento auferido no exterior fosse tributado pelos EUA e pelo Estado-fonte. ${ }^{86}$ Portanto, a lógica norte-americana se baseia na conexão pela cidadania, de modo que o crédito do imposto estrangeiro somente será concedido pelos EUA em tendo havido o pagamento do imposto na fonte. Assim é que os EUA adotam somente, em seu Modelo de convenção, o método do crédito, não havendo previsão da isenção, como no Modelo OCDE. A razão da escolha está em que pelo método do crédito será possível tributar a diferença entre a alíquota da residência e da fonte, sempre que esta for inferior àquela. A sistemática da isenção é diversa, pois mesmo que a alíquota da fonte seja menor, jamais haverá tributação pela residência. ${ }^{87}$

\footnotetext{
${ }^{84}$ Cf. L.E. Schoueri. Tax sparing: a reconsideração da reconsideração, p. 108.

${ }^{85}$ Cf. R. Doernberg, International taxation in a nutshell, p. 140. No mesmo sentido, Daniel Paço e David Rosenbloom: "Isso permite que, com a concessão de um benefício tributário pelo país de origem (...), a empresa (ou nacional) do país desenvolvido se sinta estimulada a investir no país subdesenvolvido ou em desenvolvimento, permitindo ainda que o crédito presumido sirva como uma ferramenta de financiamento do investimento feito." V. PAÇO, Daniel Hora do; ROSENBLOOM, H. David. Considerações sobre a negociação de um tratado para evitar a dupla tributação da renda com os EUA. In: ROCHA, Valdir de Oliveira (dir.), Revista Dialética de Direito Tributário 174. São Paulo: Dialética, março 2010. p. 18.

${ }^{86}$ Cf. B. Bittker e L. Lokken, Fundamentals of international taxation, p. 72-4.

${ }^{87}$ Cf. B. Bittker e L. Lokken, Fundamentals of international taxation, p. 72-4.
} 
Tomando a posição dos EUA como representativa dos demais países que rejeitam o tax sparing, retomam-se os argumentos pela reconsideração da reconsideração da OCDE.

O primeiro diz que a neutralidade de exportação de capital não é o único objetivo da tributação internacional. Pode-se priorizar a NIC, que opera pela via da isenção na residência. Neste caso, o investidor somente estaria sujeito ao tributo na fonte, concorrendo em igualdade de condições com os demais residentes naquela jurisdição. Entretanto, os EUA teriam argumento contrário, pois sequer adotam isenção como método hábil a aliviar a bitributação. Preferem o crédito pela lógica da imposição sempre que não houver risco de bitributação.

Por outro lado, seria o momento para uma reconsideração do papel da residência nos acordos, pois que fracassam em coerência. Tributando a diferença positiva, sempre que impuser alíquotas maiores que a fonte, deveria a residência, em face da situação simétrica, ofertar a restituição da diferença negativa (alíquota da fonte maior que a da residência) ao contribuinte. Agindo assim, em quaisquer situações, o investidor sempre suportaria o ônus equivalente ao da própria residência, independente de alocar seu investimento em jurisdição de tributação mais ou menos elevada.

A alegação de que o tax sparing não é um mero favor concedido pelo Estadoresidência, pois há uma repartição de competência entre os signatários do acordo que limita a jurisdição de cada qual, cabendo à fonte tributar até certo limite, a partir do qual poderá a residência exercer sua competência residual, poder-se-ia contraditar que o reconhecimento da jurisdição do outro signatário não é absoluta, pois a condição para a residência limitar sua jurisdição está no exercício daquela pela fonte. Em outro dizer, a justificativa para que uma jurisdição não avance além de seu limite de imposição é a bitributação e não a ausência do imposto.

O fato de a jurisdição da residência ter início no mesmo ponto onde cessa a jurisdição da fonte não constrói, nessa linha divisória, uma espécie de muro de concreto intransponível. Antes parece haver um êmbolo a se mover indo e vindo conforme a jurisdição da fonte e da residência prevaleçam. Sob este enfoque, em decidindo a fonte não exercer sua jurisdição sobre determinado rendimento, não haveria falar em reivindicação do direito de tributar por parte da residência, pois que o êmbolo naturalmente se moveria na direção oposta, conferindo espaço para a residência exercer sua pretensão tributária. 
Do mesmo modo, não haveria falar em falta de reconhecimento de jurisdição alheia, por meio da qual a fonte poderia integralmente exercitar sua jurisdição sobre um rendimento pré-determinado. $\mathrm{O}$ fundamento da divisão de jurisdição seria a bitributação. Ademais, os incentivos fiscais concedidos pela fonte não poderiam ser custeados pelos contribuintes da residência, afinal, se a fonte já pretendia abster-se do exercício de sua jurisdição, para que negociar um acordo para evitar bitributação?

Caberia, ainda, sustentar que o elo entre contribuinte e Estado de residência é mais forte em países cuja conexão se dá pela cidadania. Assim, à tributação na fonte segue-se um alívio por meio do crédito na residência. Quanto menor a tributação na fonte, menor o alívio e, por conseqüência, maior a imposição na residência. Cabe bem a idéia do êmbolo que vai no sentido da residência quanto mais for reduzida a tributação na fonte.

O último argumento diz que uma isenção eventualmente concedida pela residência não confere maiores prerrogativas à fonte. Trata-se de vigoroso argumento do qual se incumbirá o próximo tópico. Como relatado, ${ }^{88}$ houve sempre o predomínio do interesse da residência em detrimento da fonte, desde os primeiros modelos de acordo, ainda ao tempo da Liga das Nações.

Talvez a discussão aqui apresentada quanto às clausulas de incentivo que tantas divergências geraram e que decerto ainda gerarão, pudesse ser ampliada para uma nova repartição de competências a ser registrada em igualmente nova modelagem de acordos. O Brasil poderia assumir uma posição relevante nessa discussão.

III.2.3 Política de negociação de acordos de bitributação e inserção internacional

Paulo Casella adverte logo no intróito de sua obra BRIC - uma perspectiva de cooperação internacional: "Todos os países e cada um deles têm de cuidar de suas respectivas inserções internacionais. Tão clara a percepção de tal necessidade, como variados são os caminhos possíveis para a implementação". ${ }^{89}$

\footnotetext{
${ }^{88}$ V. tópico III.2.

${ }^{89}$ CASELLA, Paulo Borba. BRIC: Brasil, Rússia, Índia, China e África do Sul: uma perspectiva de cooperação internacional. São Paulo:Atlas, 2011, p.1.
} 
Partindo-se dessa premissa, pretende-se, neste tópico, fazer uma abordagem sobre a política de negociação dos acordos de bitributação empregada por países que têm se destacado no cenário internacional mais recente.

Alemanha e EUA representam países cujo volume de investimentos internacionais é extremamente relevante, além de constarem do topo da lista dos países com os quais o Brasil mantém estreitas relações comerciais e de investimento de capital. $^{90}$ Ademais, são países com longa tradição e produção no campo do direito tributário internacional, influenciando, talvez mais do que outros, a construção do arcabouço típico da regras desse ramo do Direito.

China e Índia ascenderam nas últimas décadas à condição de gigantes econômicos. Ambos de cultura milenar e tradição distante do Ocidente, inspira curiosidade o conhecer seus esforços em se amoldarem às regras de tributação internacional à procura de competitividade. Não bastasse, junto com Brasil e Rússia, formam o BRIC, entidade cuja perspectiva de cooperação entre seus membros tem condições de redesenhar a cooperação no mundo pós-moderno. ${ }^{91}$ Adicionalmente, dentre os maiores exportadores de IED em 2010, China e Índia estão listados como $5^{\circ} \mathrm{e}$ $20^{\circ}$, respectivamente. ${ }^{92}$

A análise se estenderá também sobre Chile e México, os dois únicos países latino-americanos a integrarem a lista de membros da OCDE; a já terem concluído acordo de bitributação com os EUA; ${ }^{93}$ e a figurarem, juntamente com o Brasil, entre os 20 maiores destinos de IED em 2010. ${ }^{94}$ Não bastasse, ao lado do Brasil e da Colômbia, representam os maiores exportadores de capital da América Latina, segundo dados da UNCTAD. ${ }^{95}$ Esses atributos são mais do que suficientes para se conhecer suas políticas de negociação de acordos de bitributação.

\footnotetext{
${ }^{90}$ Em 2010, os EUA estão no topo do fluxo de IED seja como destinatários, seja como remetentes. A Alemanha foi o $2^{\circ}$ lugar na exportação de FDI e no fluxo inverso, ocupa a $6^{\mathrm{a}}$ posição, logo após o Brasil. Cf. UNCTAD, World Investment Report 2011, pp. 4 e 9.

${ }^{91}$ Cf. P.B. Casella, Brasil, Rússia, Índia, China e África do Sul: uma perspectiva de cooperação internacional, p. 5.

${ }_{92}$ Cf. UNCTAD, World Investment Report 2011, p. 9.

${ }^{93}$ Além desses países, somente a Venezuela, dentre os latino-americanos, concluiu a negociação de um acordo de bitributação com os EUA. Dentre os três, somente o acordo com o Chile ainda não está em vigor. V. HARRIS, Daniel F. United States. In: LANG, Michael (Ed.). Recent tax treaty developments around the globe. Series on International Tax Law Univ - Prof. Dr. Michael Lang ( Ed.). Vol. 59. Viena: Linde Werlag Wien Ges.m.b.H., 2009, p.494

${ }^{94}$ UNCTAD, World Investment Report 2011, p. 4. Disponível em: http://www.unctad.org/Templates/webflyer.asp?docid=15189\&intItemID=2068\&lang=1\&mode=downloa ds. Acesso em 10 out 2011.

${ }^{95}$ Cf. UNCTAD, World Investment Report 2011, p. 7.
} 


\section{III.2.3.1 Alemanha}

Reconhecida pela liderança que exerce no seio da União Européia, a Alemanha foi o sexto principal destino de IED em $2010 .^{96}$ Dotada de uma das maiores economias do planeta, com volumes de exportação de mercadorias e capital igualmente admiráveis, a Alemanha apresenta uma das mais vetustas histórias de negociação de acordos de bitributação.

Durante o século XIX, a Alemanha estava fragmentada em 35 jurisdições, cada qual com suas leis sobre imposto de renda. Como havia estreita integração econômica entre essas jurisdições, evitar a bitributação era uma necessidade. Em 1870, foi publicada a Lei para Eliminação da Bitributação, que conferia jurisdição tributária à residência. Em 1899, surgiu a primeira convenção para evitar bitributação entre Prússia e Áustria-Hungria. ${ }^{97}$

Um risco constante para a política de acordos tributários da Alemanha é a diferença de tratamento entre situações domésticas e internacionais, que pode dar azo a um conflito com o direito comunitário. No bloco, é vedada qualquer forma de discriminação quanto às liberdades fundamentais previstas no Tratado da UUEE. ${ }^{98}$

A rede alemã de acordos de bitributação é bastante ampla, contando, atualmente, com 88 convenções. Poderia ainda ter maior alcance, não fosse pela perda dos efeitos dos acordos celebrados com Brasil, desde $1^{\circ}$ de janeiro de 2006; e com Turquia, desde $1^{\circ}$ de janeiro de 2011.99

Por ser membro da OCDE, a Alemanha assina acordos que seguem o Modelo daquela organização internacional. Logo, nos recentes acordos alemãos, observa-se conformação com o artigo 1 (pessoas cobertas) e artigo 3 (definições gerais) do Modelo OCDE . Do mesmo modo, os impostos cobertos não colidem com a previsão modelar (escopo substantivo)-imposto de renda individual e corporativo.

A fim de evitar a bitributação, a Alemanha tipicamente faz uso do método da isenção, independente de qual seja o método praticado pelo outro signatário - isenção ou crédito. Contudo, tratando-se de rendimentos como dividendos, juros, royalties e em

\footnotetext{
${ }^{96}$ Cf. UNCTAD, World Investment Report 2011, p. 4.

${ }^{97}$ KORN, Christian. Germany. In: LANG, Michael (Ed.). Recent tax treaty developments around the globe. Series on International Tax Law Univ - Prof. Dr. Michael Lang ( Ed.). Vol. 59. Viena: Linde Werlag Wien Ges.m.b.H., 2009, p.161.

${ }^{98}$ Cf. C. Korn, Germany, p. 161.

${ }^{99}$ Cf. C. Korn, Germany, p. 163.
} 
alguns outros casos especiais, excepciona-se o método da isenção e aplica-se o método do crédito. ${ }^{100}$

Os acordos alemães não possuem uma cláusula para evitar a dupla nãotributação, salvo pelo acordo com os EUA, nos moldes do art. 23(4) do Modelo OCDE. Historicamente, contudo, no combate à não (ou baixa) tributação costuma negociar cláusulas de atividade, subject-to-tax e switch-over.

Cláusulas de atividade são aplicáveis a estabelecimentos permanentes (EP) estrangeiros com o fito de reduzir o alcance do método da isenção. Em suma, caso o EP desenvolva atividades negociais (business activities) os lucros ou dividendos que venha a pagar, desde que comprovadamente oriundos de atividade negocial (definida na legislação alemã), estarão sob a égide do método da isenção. Em outras palavras, a um EP ativo corresponderá o método da isenção; a um EP passivo, o método da imputação. Dificuldades surgem para definir o que seria um EP ativo ou passivo, uma vez que atividade, para bem ser definida, exige certa dose de discricionariedade. Logo, o Estado de residência necessita de cooperação para troca de informações com o Estado de fonte, sendo que, neste caso, ambos têm interesses antagônicos. ${ }^{101}$

Cláusulas subject-to-tax foram mais usadas até os anos 70. Funcionam vinculando a isenção concedida por um Estado contratante à tributação efetiva no outro Estado contratante. Do ponto de vista alemão, a concessão da isenção estaria condicionada à efetiva tributação na fonte. $\mathrm{O}$ antigo acordo Alemanha-Canadá dispunha que "lucros, rendimentos ou ganhos de um residente de um Estado contratante serão tidos por oriundos de fontes no outro Estado contratante se eles forem tributados neste outro Estado contratante conforme esta convenção." 102 Destarte, renda que não houvesse sido tributada na fonte, não teria aquela proveniência, fugindo, pois, ao escopo da convenção. ${ }^{103}$

\footnotetext{
${ }^{100}$ Além dos rendimentos dispostos no texto, os ganhos de capital nos termos do art. 13(4) do Modelo OCDE, assim como remuneração de diretores e cláusulas de atividade ou switch-over, são exceções ao método da isenção.Cf. C. Korn, Germany, p. 170.

${ }^{101}$ Cf. C. Korn, Germany, p. 172. Andreas Perdelwitz observa que a cláusula de atividade perdeu o sentido, a contar de 2002, para dividendos de fonte estrangeira, devido ao fato de a isenção concedida não exigir atividade por parte da subsidiária. Cf. PERDELWITZ, Andreas. Country Analyses: Germany. In: International Bureau of Fiscal Documentation Tax Research Plataform,7.4.1.2. Disponível em: www.ibfd.org. Acesso em 17 dez 2011.

${ }^{102}$ No original: “(...) profits, income or gains of a resident of a Contracting State shall be deemed to arise from sources in the other Contracting state if they are taxed in that other Contracting State in accordance with this Agreement." (tradução livre). A cláusula subject-to-tax constava deste acordo Alemanha-Canadá de 1981. O novo acordo entre esses países, em vigor desde 2001, não contém tal previsão. Cf. C. Korn, Germany, p. 173.

${ }^{103}$ Cf. C. Korn, Germany, p. 173.
} 
Já cláusulas switch-over simplesmente trocam o método da isenção pelo do crédito. Para tanto, a fonte deve ter eliminado ou reduzido sua imposição por meio da aplicação do acordo. Um exemplo seria o Art. 10 (2) dividendos, em que a fonte tributa, geralmente, a menor do que o previsto em sua legislação doméstica. ${ }^{104}$

A Alemanha está dentre os países europeus que costumavam garantir à fonte a faculdade de exercerem ou não sua jurisdição, incluindo, em seus acordos com países em desenvolvimento, cláusulas de tax sparing e matching credit. No caso do acordo com o Brasil, justamente esse tema foi um dos principais que levaram os europeus a denunciarem o acordo em 2005. Segundo os alemães, passou a haver um desequilíbrio nas relações com o Brasil, pois que o acordo fora assinado em 1975, conforme a política de incentivo ao investimento e crescimento dos PED. Trinta anos mais tarde a situação brasileira havia se modificado, de modo que a qualificação do País como subdesenvolvido tornou-se difícil. Por outro lado, o orçamento alemão também passou a exigir maior controle em tempos de globalização. Logo, a Alemanha passou a alegar que seus métodos "para eliminar a bitributação com relação ao Brasil eram mais favoráveis do que aqueles utilizados pelo Brasil com relação à Alemanha.",105

No acordo Brasil-Alemanha, havia uma previsão de matching credit, por meio da qual a Alemanha concederia um crédito de $20 \%$ ou $25 \%$ a seus residentes em face da tributação brasileira de $15 \%$ sobre determinados rendimentos. ${ }^{106}$ Talvez a manutenção desse dispositivo favorecesse ainda mais a alocação do investimento alemão no Brasil, a despeito da boa política de investimento que permaneceu entre os dois países após a denúncia do acordo.

Outros países mantêm acordos de bitributação com a Alemanha e são beneficiados pelo crédito assegurado ao investidor alemão independente da baixa ou nenhuma tributação na fonte. Dentre eles, destacam-se: Argentina, China, Grécia, Irlanda, Israel, Portugal, Espanha, Turquia e Uruguai. ${ }^{107}$

\footnotetext{
104 A Alemanha tende a usar cláusulas switch-over em seus mais recentes tratados, mas sua aplicação depende de um inócuo procedimento para acordo recíproco ou de uma notificação ao Estado da fonte, A Alemanha, portanto, não pode trocar da isenção para o crédito de forma unilateral. Há, ainda, uma extensão dos efeitos dessas cláusulas nos acordos alemães que se aplicam não somente sob a inspiração do art. 23 (4) do Modelo OCDE, mas também sempre que a isenção ou redução da tributação resultar da legislação doméstica da fonte. Cf. C. Korn, Germany, pp. 174-175.

105 CASTELON, Marta Oliveros. Perspectivas de novo acordo Brasil-Alemanha. In: Filho, C.P.; Tonani, F.; Behrndt M.A.; Ribeiro, R.P; Vasconcellos, R.F. (coord.), Revista de direito tributário internacional. Ano 3, nº, São Paulo: Quartier Latin, 2008, p.166.

${ }^{106}$ Cf. M.O.Castelon, Perspectivas de novo acordo Brasil-Alemanha, p.166.

107 Cf. A. Perdelwitz, Country Analyses: Germany, 7.4.1.6.2. O benefício, com relação à Espanha, restringe-se a um crédito de $10 \%$ somente referente a juros, se os juros forem pagos a uma instituição bancária e o imposto espanhol sobre esses juros for inferior a $10 \%$.
} 
Embora a Alemanha não tenha uma política de acordos tributários orientada para cláusulas LOB, mais recentemente tem feito constar provisões que permitem aplicação de regras anti-abuso. Sinteticamente, o objetivo das cláusulas LOB é impedir que o acordo beneficie pessoas que não são cobertas por seu alcance - treaty shopping. ${ }^{108}$

Os acordos alemães costumam seguir as regras de não discriminação do art. 24 do Modelo OCDE. Da mesma forma, seguem o art. 26, no tocante à troca de informações e assistência mútua. Neste quesito, inclusive, a Alemanha lidera uma posição de redução aos limites de troca de informações, especialmente bancárias em casos de suspeita de evasão fiscal. ${ }^{109}$

A política alemã de negociação de acordos, nos próximos anos, deverá proceder à revisão de seus acordos mais antigos, amoldando-os aos seus interesses atuais e aos novos desafios da ordem internacional pós-moderna. Improvável, em face das alterações e incertezas trazidas pela pós-modernidade que a Alemanha mantenha-se tão aberta a negociar cláusulas de incentivo - tax sparing e matching credit- como outrora. A célere mudança nas economias emergentes exige maior cautela para avaliar a inclusão dessas cláusulas em seus acordos.

Uma outra tendência demonstrada na política de acordos tributários recente da Alemanha diz com a preocupação acerca da inclusão de cláusulas anti-abuso, que em último grau, representam combate à evasão ou preservação de receitas. Neste último caso, as cláusulas de atividade, subject-to-tax ou switch-over adquirem maior importância.

\section{III.2.3.2 Chile}

O Chile tem se destacado no contexto internacional por suas apregoadas prosperidade econômica e estabilidade política. Ao lado do Brasil e do México, compõe o grupo de países latino-americanos entre os 20 que mais receberam IED no mundo em

\footnotetext{
${ }^{108}$ Para maiores informações sobre treaty shopping, v. SCHOUERI, Luís Eduardo. Planejamento fiscal através de acordos de bitributação: treaty shopping. São Paulo: Editora Revista dos Tribunais, 1995; BITTKER, Boris; LOKKEN, Lawrence. Fundamentals of international taxation. NY: WG\&L RIA, 2008/2009, itens 67.3.3, 67.6.9 e 67.8.4.

${ }^{109}$ Cf. C. Korn, Germany, pp. 178-179.
} 
2010. ${ }^{110}$ Além disso, é o primeiro Estado da América do Sul a ingressar na OCDE. ${ }^{111}$ Focado, portanto, em projetar-se internacionalmente com vistas ao desenvolvimento, o Chile adotou uma agressiva política de negociação de acordos de bitributação, que costuma se fazer acompanhar pela negociação concomitante de acordos de livre comércio.

Seguro da pequenez de seu mercado interno, o Chile prioriza as relações comerciais e de investimento, o que tem se traduzido pelas céleres negociações tanto em acordos bilaterais de livre comércio como de bitributação. ${ }^{112}$

O primeiro acordo de bitributação chileno foi firmado com a Argentina, entrando em vigor aos 07/03/1986. Em sua forma, seguiu o Modelo do Pacto Andino, apesar de o Chile não se encontrar dentre os membros daquele grupo. ${ }^{113}$ Este acordo representou o primeiro passo para uma intensa política de acordos tributários posta em prática a partir de 1998, por meio da qual o Chile tem seguido, prioritariamente, o Modelo OCDE, apesar de alguns desvios no sentido de fortalecer a tributação na fonte, mais ao molde de algumas específicas cláusulas do Modelo ONU. ${ }^{114}$

Como resultado das negociações, o Chile atingiu 24 acordos já em vigor, 4 cuja negociação já está concluída e mais outros 12 em negociação, o que significa uma rede de 40 acordos que deverá estar concluída em futuro breve, ${ }^{115}$ superando a rede brasileira de acordos que soma 33 incluindo os que ainda não entraram em vigor.

Em suas negociações, o Chile escolheu parceiros nos acordos de bitributação por razões diversas. Na América do Sul, Equador e Peru receberam fluxos crescentes de investimentos chilenos nos anos 90. Já no sentido oposto, investimentos do Brasil, Canadá, México, Noruega e Espanha adquiriram grande relevo para a economia chilena. A escolha da Croácia, Coréia do Sul, Reino Unido e França se deveu mais ao intercâmbio comercial, restando, mais recentemente, Estados Unidos, China e Índia

\footnotetext{
${ }_{110}$ Cf. UNCTAD, World Investment Report 2011, p. 4.

${ }^{111} \mathrm{O}$ acordo de acesso à OCDE, foi assinado em Santiago do Chile aos 10 de janeiro de 2010. Maiores informações em www.oecd.org.

112 GÁRATE, Cristián. Chile. In: LANG, Michael (Ed.). Recent tax treaty developments around the globe. Series on International Tax Law Univ - Prof. Dr. Michael Lang ( Ed.). Vol. 59. Viena: Linde Werlag Wien Ges.m.b.H., 2009, p.62.

${ }^{113}$ Cf. C. Gárate, Chile, p. 61.

${ }^{114}$ Cf. C. Gárate, Chile, p. 61.

${ }^{115}$ Cf. dados oficiais dispostos no sítio do Servicio de Impuestos Internos do Chile, www.sii.cl. Dentre os acordos já em vigor, encontram-se: Argentina, Bélgica, Brasil, Colômbia, Coréia do Sul, Croácia, Dinamarca, Equador, Espanha, França, Irlanda, Malásia, México, Noruega, Nova Zelândia, Paraguai, Peru, Polônia, Portugal, Reino Unido, Suécia, Suíça e Tailândia. Já conclusos estão os acordos com África do Sul, Austrália, Estados Unidos e Rússia. Em negociação, por sua vez, destacam-se: Áustria, China, Cuba, Finlândia, Holanda, Hungria, Índia, Itália, Kuwait, República Tcheca, Uruguai e Venezuela.
} 
como parceiros desejados pela grandeza de seus mercados e pela pujança de suas economias. $^{116}$

Em todos os casos, pode-se asseverar que Chile priorizou importantes parceiros comerciais com o objetivo de garantir maior segurança ao investidor, reduzindo-lhes os riscos de bitributação.

Quanto ao conteúdo dos acordos chilenos, en passent, destaca-se que o Chile não se desvia do Modelo OCDE no concernente ao escopo pessoal dos acordos (art. 4 residência), apenas adicionando o critério da cidadania no acordo com os EUA. Em sua maioria, os acordos chilenos não prevêem cláusulas LOB, com exceção dos acordos com EUA, Colômbia, Nova Zelândia, Rússia e Austrália, os quais seguem os comentários da OCDE. ${ }^{117}$

Materialmente, os acordos chilenos seguem o Modelo OCDE quanto aos impostos sobre renda e capital, conforme a Lei do Imposto de Renda chileno, a saber: IRPF, IRPJ, Imposto sobre ganhos de capital, imposto sobre salários, imposto sobre a alienação de propriedade mobiliária (tangível e intangível) e imobiliária, imposto sobre o encerramento de empresas, e retenções sobre ganhos de atividades realizadas no Chile e enviados para o exterior. O Chile, no entanto, reservou sua posição quanto aos impostos subnacionais. ${ }^{118}$

O Chile segue a mesma estrutura dos artigos 6 a 22 do Modelo OCDE, que tratam sobre repartição de competência tributária entre os signatários. Com relação aos artigos 7 (lucros de empresas), 10 (dividendos), 11 (juros) e 12 (royalties), o tratamento conferido pelos acordos chilenos não enseja maior detalhamento, posto que seguem o Modelo OCDE sem desvios substanciais. ${ }^{119}$

Quanto ao objetivo primordial de evitar a bitributação, os acordos chilenos valem-se do método da imputação, já que a política de acordos tributários do País prioriza assegurar a neutralidade independente do fluxo das transações - inbound ou outbound transactions. ${ }^{120}$ Neste sentido, a reciprocidade não é capaz de alterar o método do crédito aos residentes chilenos em caso de aplicação, pelo outro signatário, de método distinto aos seus próprios residentes. ${ }^{121}$

\footnotetext{
${ }^{116}$ Cf. C. Gárate, Chile, p. 62.

${ }^{117}$ MASSONE, Pedro. Country Analyses: Chile. In: International Bureau of Fiscal Documentation Tax Research Plataform,7.4.1.6.1. Disponível em: www.ibfd.org. Acesso em 17 dez 2011.

${ }^{118}$ Cf. C. Gárate, Chile, p. 64.

${ }^{119}$ Cf. C. Gárate, Chile, pp. 66-68.

${ }^{120}$ Cf. P. Massone, Country Analyses: Chile, 7.4.1.2.

${ }^{121} \mathrm{O}$ acordo com a Argentina é o único que prevê o método da isenção. Cf. C. Gárate, Chile, p.73.
} 
O Chile apresenta-se como um Estado cooperativo no que tange à troca de informações, seguindo o Modelo OCDE. Em alguns de seus acordos, inclui uma previsão para informação específica, como depoimento de testemunhas, cópias de documentos, incluindo livros, papéis, declarações, arquivos e contas, que deverão ser apresentados na mesma medida em que tais informações possam ser obtidas segundo a legislação do outro signatário. O Chile não inclui em seus acordos a cláusula sobre assistência mútua quanto à arrecadação de impostos. ${ }^{122}$

Em sua política de negociação de acordos de bitributação, o Chile mostra-se bastante atuante, pois tem bem definidos seus objetivos. Toda a rede de acordos foi cuidadosamente pensada, a fim de trazer resultados práticos com a máxima eficácia em curto espaço de tempo. A idéia central chilena é de buscar integração com o resto do mundo e aprimorar sua política fiscal de modo a atingir, jurídica e economicamente, resultados comparáveis aos de outros membros da OCDE. ${ }^{123}$ Aliás, empenhado em ingressar na OCDE desde 1998, conseguiu seu intento em 2010, o que se lhe afigura como ótima oportunidade de ampliação de mercados e do fluxo de investimentos.

O Chile não incorporou cláusulas de incentivo em sua recente (e atual) política de negociação, ressalvado o acordo com a Malásia. ${ }^{124}$ A falta do tax sparing parece não lhe ser uma adversidade, pois conseguiu importantes acordos de bitributação e de livre comércio - dentre os quais com os EUA -, de modo que suas prioridades estão mais afeitas a um sistema baseado em virtudes concretas. Em outro dizer, na construção de instituições sérias, capazes de atuarem com rapidez e segurança no cenário internacional.

A principal preocupação quanto à exitosa política de negociação de acordos chilena diz com a vital preservação das receitas tributárias. Com efeito, uma grande rede de acordos de bitributação se traduz por relevantes intercâmbios comerciais e de investimentos, o que, em um mercado pequeno como o chileno, exige maior atenção sobre os efeitos desses fluxos no orçamento. Por vezes, o melhor tratamento aos rendimentos dos artigos 10 a 12 - dividendos, juros e royalties - poderá ser aquele fora do âmbito dos acordos, já que estes reduzem os limites de jurisdição da fonte. ${ }^{125}$

\footnotetext{
${ }^{122}$ Cf. C. Gárate, Chile, p. 74.

${ }^{123}$ Cf. C. Gárate, Chile, p. 75.

${ }^{124}$ Cf. P. Massone, Country Analyses: Chile, 7.4.1.6.2.

${ }^{125}$ Cf. C. Gárate, Chile, pp. 75-76.
} 
Por fim, o Chile demonstra interesse em produzir seu próprio modelo de acordo de bitributação, harmonizando sua política de negociação internacional com seus objetivos tributários domésticos. Um modelo chileno conferiria ainda maior segurança ao investidor que poderia comparar suas cláusulas com as previstas nos modelos OCDE e ONU, tudo com o fim de impulsionar o País ao crescimento. ${ }^{126}$

Vê-se que o Chile tem bons exemplos a servir de inspiração ao Brasil. Iniciando as discussões sobre bitributação com largo atraso, em poucos anos o Chile foi capaz de construir uma rede de acordos significativa. A proposta chilena é fruto de um planejamento bem feito, sem interrupções. O Brasil, apesar de suas diferenças geográficas e econômicas, deveria considerar uma política de negociação de acordos tributários consistente como uma alavanca de impulso para a competitividade e inserção internacional. Entretanto, não é o sinal que dá. O País parece, quanto a este tema, algo acomodado, sem uma proposta nítida quanto aos resultados que pretende alcançar.

\section{III.2.3.3 China}

A China também começou a assinar acordos de bitributação bem depois do Brasil, quando celebrou com o Japão, em 1983, sua primeira convenção. Desde então, a economia chinesa atingiu índices extraordinários, levando o País a uma posição de destaque internacional. ${ }^{127}$ Trata-se, pois, do segundo maior destino do IED em 2010, com US\$ 106 bilhões aportando em seu território. ${ }^{128}$

Hoje, a rede de acordos de bitributação chinesa chega a impressionantes 90 convenções, não havendo um membro da OCDE que lhe escape da condição de signatário. Na fase inicial de negociações, a China priorizava o Modelo ONU, em razão de sua preferência pelo princípio da fonte. Contudo, o Modelo OCDE ganhou espaço na década de 90, devido, mormente, à mudança de situação da China de mera importadora para exportadora de capital. ${ }^{129}$

\footnotetext{
${ }^{126}$ Cf. C. Gárate, Chile, p. 76.

${ }^{127}$ CAI, Qiaoping. China. In: LANG, Michael (Ed.). Recent tax treaty developments around the globe. Series on International Tax Law Univ - Prof. Dr. Michael Lang ( Ed.). Vol. 59. Viena: Linde Werlag Wien Ges.m.b.H., 2009, p.79.

${ }^{128}$ Cf. UNCTAD, World Investment Report 2011, p. 4

${ }^{129}$ Cf. Q. Cai, China, p 79.
} 
Três estágios marcam a política chinesa de negociação e acordos de bitributação: ${ }^{130}$

(i) 1983 a 1993: China assinou 32 acordos, sendo a maioria deles com membros da OCDE. Não foi o acaso quem determinou os diversos contratantes, mas uma política orientada para atração do IED, que já tivera início por meio da abertura e das reformas empreendidas no País. Esta fase marca a relação estreita da política de acordos tributários chinesa com sua política macroeconômica. Era preciso convencionar com os membros da OCDE a fim de atrair seus investidores. Ademais, era preciso negociar com o máximo de benefícios mantidos na fonte. - menor tempo para qualificação como EP e maiores alíquotas de retenção sobre rendimentos passivos;

(ii) 1994-2000: outros 33 acordos foram concluídos neste breve período, que marcou o início da migração das empresas e investidores chineses para outros países em desenvolvimento. Estes, por seu turno, o alvo preferencial chinês nesta fase. Embora a China começasse a exercer um papel relevante como exportador de capital, priorizando a residência em acordos com PED, era preciso manter-se atrativo ao IED. Em resumo, a política chinesa nesta fase deveria estimular o investidor doméstico e o estrangeiro. A saída foi lançar mão de um tax sparing recíproco, cláusula que foi inclusa em diversos acordos celebrados neste período;

(iii) 2001- atual: o objetivo da política de acordos de bitributação, neste estágio, é encorajar a saída de capital doméstico e aumentar a competitividade internacional das empresas chinesas. Assim, os Estados desejosos de atrair IED da China têm maiores chances de firmar acordos com ela. ${ }^{131}$

Os acordos chineses, quanto ao escopo pessoal, acompanham, sem exceção, o artigo 1 (pessoas cobertas), mas não o artigo 4 (residência) do Modelo OCDE. De fato, a China prefere o local da incorporação ou da matriz (head office) como critério definidor de residência. A uma, porque a legislação chinesa impede que um investidor estrangeiro produza renda ativa sem que a empresa seja incorporada na China; a duas, porque autoridades chinesas entendem mais fácil precisar o local da incorporação ou da matriz do que o local da gerência da empresa. ${ }^{132}$

\footnotetext{
${ }^{130}$ Cf. Q. Cai, China, pp. 80-81.

${ }^{131}$ Neste período, a China negociou acordos com os três últimos ingressantes da OCDE: Grécia e México (já concluídos) e Chile ( em negociação). Cf. Q. Cai, China, pp. 80-81 e C. Gárate, Chile, p. 61.

${ }^{132}$ Cf. Q. Cai, China, p 84.
} 
Em seu escopo substantivo (artigo 2 do Modelo OCDE), os acordos chineses cobrem o imposto de renda da pessoa física e da pessoa jurídica.

Quanto às regras de distribuição de competências, há uma prevalência do Modelo OCDE, conquanto haja, ainda, algumas características do Modelo ONU e da própria política chinesa. Com relação a dividendos, juros e royalties, comparando-os com o disposto no Modelo OCDE, tem-se: ${ }^{133}$

(i) artigo 10- dividendos: a competência cumulativa da fonte é limitada a 5\% pela OCDE, podendo chegar a 15\%. ${ }^{134}$ Os acordos chineses prevêem, geralmente, $10 \%$, podendo ser zero (Geórgia) ou 20\% (Tailândia);

(ii) artigo 11- juros: OCDE limita a 10\% a jurisdição da fonte. Acordos chineses, geralmente, limitam em 10\%, sendo que podem variar de 5\% (Kuwait e Venezuela) a $15 \%$ (Brasil).

(iii) artigo 12 -royalties: OCDE atribui competência exclusiva para a residência; China fixa a jurisdição da fonte a 10\%, podendo variar de 5\% (Cuba) a 25\% (Brasil).

A fim de evitar a bitributação, os acordos chineses somente contemplam o método do crédito. Ainda que o outro signatário utilize o método da isenção, a China manterá o crédito como única alternativa viável a seus residentes. Como a China adota o crédito ordinário, limitado ao imposto chinês sobre a renda estrangeira, eventual excesso poderá ser compensado pelo período de 5 anos. ${ }^{135}$

Importante a adoção do tax sparing como garantia das normas tributárias indutoras regradas pela Lei do Imposto de Renda das Empresas da República Popular da China, assim como pela legislação subjacente. A China tem por hábito negociar o tax sparing, ofertando ao outro signatário a possibilidade de uma cláusula mútua de incentivo. Em alguns casos há a previsão da limitação temporal ao tax sparing, a qual pode ser estendida por força dos procedimentos para acordo recíproco entre as autoridades fazendárias. ${ }^{136}$

A China não foge à regra de não discriminação prevista no Modelo OCDE. Por outro lado, adota posição extremamente conservadora no que tange à troca de informações e assistência mútua, resistindo a incluir cláusulas dispondo sobre o tema

\footnotetext{
${ }^{133}$ Cf. Q. Cai, China, p 85-86.

${ }^{134}$ CF. OCDE, Convenção Modelo, art. 10: 5\% se aquele que recebe os dividendos detiver, diretamente, pelo menos $25 \%$ das ações da empresa que paga dividendos. Em todos os demais casos, $15 \%$.

${ }_{135}$ MA, Shi Qi. Country Analyses: China. In: International Bureau of Fiscal Documentation Tax Research Plataform. 7.2.6. Disponível em: www.ibfd.org. Acesso em 17 dez 2011.

${ }^{136}$ Cf. Q. Cai, China, p 88 .
} 
em seus acordos. Espera-se, porém, que o aumento das exportações de capital chinês e a abertura da economia possam levar as autoridades a reverem sua posição. ${ }^{137}$

A grande lição da política de acordos tributários chinesa está em sua capacidade de mudança face às céleres alterações sofridas pela economia chinesa. Grande senso de percepção foi necessário para dividir em três estágios os objetivos, sempre distintos, da negociação de acordos de bitributação.

A China exerce notável atração sobre o IED, ao mesmo tempo em que suas empresas lançam-se mundo afora em busca de lucros. Paradoxalmente, o gigante asiático mais populoso do planeta ainda estagia como país em desenvolvimento no qual se encontram ampla ineficiência administrativa e radicais desigualdades. Como resultado, sua política de negociação de tratados não pode se aproximar em demasia da residência favorecida pelo Modelo OCDE, mas tampouco prescindir da tributação na fonte, conforme o Modelo ONU. Buscar o equilíbrio vai depender de quem se sentar à mesa para negociar com a China. Assim, os fluxos de capital e o volume das transações comerciais serão fundamentais para definir, caso-a-caso, qual o mais adequado texto a ser proposto na convenção. ${ }^{138}$

Seguramente, contudo, pode-se apontar o tax sparing como autêntico instrumento garantidor das normas tributárias que pretendem induzir o comportamento dos investidores. No caso da China, há o interesse de incluí-lo como cláusula recíproca em que tanto se estimula a vinda do investidor estrangeiro, como a saída do investidor doméstico.

Da política de acordos tributários chinesa pode-se extrair a cláusula mútua de tax sparing como modelo de interesse para o Brasil. Os tradicionais exportadores de capital podem claudicar em ofertar incentivos a países que já apresentam destaque na economia mundial, especialmente se as projeções futuras forem nesse mesmo sentido. Assim, ao incluir uma via de mão dupla na questão do tax sparing, o Brasil ganharia em competitividade, seguindo o exemplo chinês.

\section{III.2.3.4 Estados Unidos}

\footnotetext{
${ }^{137}$ Cf. Q. Cai, China, p 88.

${ }^{138}$ Cf. Q. Cai, China, p 89.
} 
A política de acordos de bitributação dos EUA pode ser de interesse para o Brasil, que iniciou a negociação de uma convenção dessa natureza com os norteamericanos ainda na década de 60, sem que houvesse a conclusão do acordo até o presente. Como é sabido, a principal razão para a inconclusão da negociação se deve à proposta brasileira de inclusão de uma cláusula de tax sparing, algo que para os EUA é inaceitável. $^{139}$

A escolha de parceiros em arranjos bilaterais contra a bitributação é feita de forma bastante meticulosa, de modo que, na análise da política alheia, os EUA sobrelevam a disposição para troca de informações, limitação de benefícios para evitar que terceiros se beneficiem do acordo - treaty shopping -, e solução amigável em eventuais querelas por tributação em desacordo com a convenção. ${ }^{140}$ Além desses, fatores como fluxo de IED, histórico comercial, elos políticos, concorrência tributária, redução dos custos administrativos de arrecadação, aumento da eficiência, combate à evasão fiscal também levam os EUA a negociar e concluir acordos de bitributação. ${ }^{141}$

OS EUA contam hoje com uma rede de 68 acordos de bitributação ${ }^{142}$ e uma vasta experiência histórica no assunto, pois desde os anos 30 assinam tais convenções bilaterais. Os EUA editaram seu próprio modelo de convenção em 1977, o qual sofreu uma revisão em 2006. Este é o ponto de partida de qualquer negociação empreendida pelos EUA, de modo que sua política de acordos tributários pode ser conhecida e estudada por outros Estados, o que facilita eventual negociação. ${ }^{143}$ Como o Modelo EUA é semelhante ao da OCDE, crucial a identificação das dissonâncias para que seja alvo de negociação mais intensa até o fechamento do novo texto.

Dentre os países analisados neste tópico, somente o Brasil não possui um acordo de bitributação com os EUA, já que os norte-americanos mantêm, em sua rede, acordos com Alemanha, China, Índia, México e, num passado menos remoto, Chile. Em 2007, o Brasil celebrou um acordo para troca de informações em matéria fiscal com os EUA, o

\footnotetext{
${ }^{139}$ Os EUA rejeitaram , pelo mesmo motivo, acordos com Egito e Paquistão. V. TAYLOR, Willard B. O que um acordo de bitributação entre Brasil e EUA poderia estipular? In: COSTA, Alcides Jorge; SCHOUERI, Luís Eduardo e BONILHA, Paulo Celso Bergstrom (coord.), Direito Tributário Atual 21. São Paulo: Dialética, 2007. p. 153.

${ }^{140}$ Cf. W. B. Taylor, O que um acordo de bitributação entre Brasil e EUA poderia estipular?, p. 153.

${ }^{141}$ HARRIS, Daniel F. United States.. In: LANG, Michael (Ed.). Recent tax treaty developments around the globe. Series on International Tax Law Univ - Prof. Dr. Michael Lang ( Ed.). Vol. 59. Viena: Linde Werlag Wien Ges.m.b.H., 2009, p.491 a 512.

${ }^{142}$ Cf. IRS, dados oficiais disponíveis em sua página virtual www.irs.gov. O acordo com o Chile já teve sua negociação encerrada embora ainda não esteja em vigor..

${ }^{143} \mathrm{Cf}$. W. B. Taylor, O que um acordo de bitributação entre Brasil e EUA poderia estipular?, p. 152.
} 
que pode representar um passo inicial no sentido da concretização de um acordo de bitributação. ${ }^{144}$

A política de negociação de acordos de bitributação é dinâmica, devendo acompanhar as alterações registradas no cenário doméstico e internacional. Os EUA costumam, ao mesmo tempo em que negociam novos, revisar seus antigos acordos com vistas a aumentar os benefícios convencionados, expandir a rede de tratados, combater a evasão e manter-se atualizado com a OCDE. ${ }^{145}$

O Modelo EUA excede o escopo pessoal do Modelo OCDE em seus artigos 1 (pessoas cobertas) e 4 (residência), destacando-se as restrições de aplicação do acordo a entidades transparentes - partnerships -, assim como as saving clauses, por meio das quais os EUA salvam seu direito de alcançar seus cidadãos independente de serem residentes do outro Estado contratante. Boa ilustração sobre essas cláusulas é trazida por Doernberg, a saber: "Um residente do Reino Unido, que não é cidadão dos EUA, pode se valer do artigo 11 do acordo EUA- Reino Unido para evitar a tributação norteamericana de juros pagos por um tomador americano. Todavia, se este mesmo residente do Reino Unido fosse um cidadão norte-americano, os EUA reservam o direito, sob o artigo 1(4), de tributar integralmente os juros como se o acordo não estivesse em vigor. Mesmo se os juros fossem pagos por um tomador do Reino Unido para um residente no reino Unido, os EUA tributarão tais juros desde que o residente no Reino Unido seja também um cidadão dos EUA.",146

Uma característica marcante da política de acordos tributários dos EUA é a inclusão de cláusulas LOB em seus acordos, o que, inclusive, vem sendo observado por outros países. Por meio delas, vários testes são aplicados para conferir a elegibilidade para os benefícios do acordo. ${ }^{147}$

Os impostos cobertos são os mesmo previstos no Modelo OCDE, ou seja, sobre a renda de indivíduos e empresas, mas somente no âmbito federal. Os acordos não abrangem imposto de renda estadual ou municipal. ${ }^{148}$

\footnotetext{
${ }^{144} \mathrm{Cf}$. W. B. Taylor, O que um acordo de bitributação entre Brasil e EUA poderia estipular?, p. 151.

${ }^{145}$ Recentemente foram renegociados, dentre outros, os acordos com Áustria, Bélgica, Islândia, Itália, Japão e Reino Unido.Cf. D. F. Harris, United States, pp. 499-500.

${ }^{146}$ No original: a resident of the United Kingdom who is not a US citizen can rely on Article 11 of the US- United Kingdom treaty to avoid US taxation of interest paid by a US borrower. However if that UK resident were a US citizen, the Unites States reserves the right under Article 1(4) to tax fully the interest income, as if the treaty were not in effect. Even if the interest is paid by a UK borrower to a resident of the United Kingdom, the United States will tax the interest if the UK resident is also a US citizen(...)" Cf. R. Doernberg, International taxation in a nutshell, p. 113.

${ }^{147}$ Cf. D. F. Harris, United States, pp. 501.

${ }^{148}$ Cf. W. B. Taylor, O que um acordo de bitributação entre Brasil e EUA poderia estipular?, p. 153.
} 
Quanto às regras de distribuição de competência sobre rendimentos passivos, geralmente, na ausência de um acordo de bitributação, tais rendimentos de fonte norteamericana seriam tributados por meio de retenção na fonte - withholding tax- a 30\%. Quanto aos juros, esse regramento vigeu até 1984, quando juros de portfólio deixaram de ser tributados. Já quanto aos royalties, a retenção de 30\% reduz-se para zero, já que somente serão tributados no Estado de residência do beneficiário efetivo desse pagamento. No caso dos dividendos, a retenção na fonte de $30 \%$, cai para $15 \%$ (casos gerais); $5 \%$ (se o beneficiário detiver pelo menos $10 \%$ do poder de voto da sociedade) ou zero (se pagos a plano de pensão). ${ }^{149}$

Como alívio para a bitributação os acordos norte-americanos prevêem o método do crédito tão-somente, distando da OCDE que também faculta a isenção. Embora os EUA adotem a tributação em bases mundiais - worldwide income taxation-, reconhecese um crescente movimento favorável à territorialidade, baseado no fato de que a universalidade estimula a concorrência tributária internacional e, ainda, no desejo de que as MNEs registrem-se nos EUA. ${ }^{150}$

A obrigação recíproca de não tributar os residentes ou cidadãos do outro Estado contratante de forma mais gravosa que aos próprios - não-discriminação - está gravada no artigo 24 do Modelo EUA, assim como do Modelo OCDE. ${ }^{151}$ Já o artigo 26 do Modelo EUA reúne troca de informação e assistência administrativa, correspondendo, respectivamente aos artigos 26 e 27 do Modelo OCDE. Todos os acordos concluídos recentemente prevêem MAP - procedimentos para acordo recíproco ou solução amigável. $^{152}$

$\mathrm{Na}$ última década, a política norte-americana focou nas cláusulas LOB, na repartição de informações e na busca por IED. Com a crise mundial ainda sem solução definitiva, os EUA devem regular a negociação de seus acordos sob a constatação de que os fluxos de IED destinam-se, em sua maior parte, para os BRIC e países produtores de petróleo. ${ }^{153}$

\section{III.2.3.5 Índia}

\footnotetext{
${ }^{149}$ Cf.W. B. Taylor, O que um acordo de bitributação entre Brasil e EUA poderia estipular?, p. 154.

${ }^{150}$ Uma alteração para a territorialidade provavelmente alterará o método de alívio da bitributação para a isenção. Cf. D. F. Harris, United States, pp. 506

${ }^{151}$ Cf. R. Doernberg, International taxation in a nutshell, p. 134-136.

${ }^{152}$ Cf. D. F. Harris, United States, pp. 509-510

${ }^{153}$ Cf. D. F. Harris, United States, pp. 512.
} 
Nas duas últimas décadas o engajamento indiano com o restante do planeta cresceu significativamente. Através da expansão de suas relações comerciais e de investimentos com países desenvolvidos paralelamente à concretização de parcerias para cooperação técnica e econômica com países em desenvolvimento, a Índia conseguiu um célere avanço tecnológico aliado a um crescimento econômico. Para a consecução desses resultados, a política de negociação de acordos de bitributação pode ser tida como um dos relevantes elementos da política econômica indiana. ${ }^{154}$

A atual política de acordos de bitributação visa à expansão do número de convenções simultaneamente à revisão dos acordos já em vigor. Os acordos são tidos por instrumentos para evitar a bitributação, combater a evasão de receitas e, principalmente, reduzir as barreiras ao comércio e aos fluxos de capital. Diferente de outros países, dentre os quais o Brasil, na Índia os acordos não precisam ser aprovados pelo Parlamento para entrar em vigor. ${ }^{155}$

O primeiro acordo de bitributação da Índia foi assinado com a Áustria em 1963. Por sua peculiaridade merece registro, uma vez que foi baseado em regras fechadas (closed rules), isto é, regras de distribuição de competência exclusiva, de modo que à fonte coube tributar diversos rendimentos, como dividendos, juros, royalties e ganhos de capital dentre outros. Posteriormente, em 1999 este acordo foi renegociado, passando aos moldes da Convenção OCDE. ${ }^{156}$

O tratamento conferido pela Índia quanto à remuneração de serviços técnicos, de consultoria ou de gerenciamento difere se o outro signatário for um PD ou PED. Com países desenvolvidos, a Índia inclui uma cláusula conferindo jurisdição ao Estado em que se encontra o residente para quem tais serviços foram prestados por um residente do

${ }^{154}$ GUPTA, Sunil. Índia. In: LANG, Michael (Ed.). Recent tax treaty developments around the globe. Series on International Tax Law Univ - Prof. Dr. Michael Lang ( Ed.). Vol. 59. Viena: Linde Werlag Wien Ges.m.b.H., 2009, pp. 225.

${ }^{155}$ Cf. S. Gupta, Índia, p. 225. No Brasil, há um processo multifásico que exige a presença do Executivo e do Legislativo. O primeiro negocia e assina o texto, deixando-o pendente de confirmação, que só ocorrerá após o Legislativo aprová-lo. Com a manifestação do Parlamento, pode o Executivo ratificar o acordo. A fase seguinte se dá por meio de Decreto Presidencial em que ocorre a promulgação e a publicação do acordo. Os tratados internacionais podem viger simultaneamente ao consentimento das partes ou posteriormente - vacatio. O diferimento da vigência é mais seguro, pois permite que o acordo seja conhecido internamente, a fim de ser preservado e respeitado pelos cidadãos, administradores e pelo Judiciário. Prudência maior assiste ao diferimento da vigência nos acordos de bitributação, já que, por sua própria natureza, relacionam investidores privados com mais de um Estado soberano, sendo portanto evocável a qualquer tempo, antes mesmo que as autoridades públicas o conheçam suficientemente para aplicá-lo. Cf. F. Rezek, Direito internacional público, pp. 73-74.

${ }^{156}$ Antes disso, a Índia já havia assinado um acordo restrito sobre isenção recíproca quanto à aviação com o Afeganistão, em 1952. Cf. S. Gupta, Índia, p. 225 
outro signatário. Há, entretanto acordos em que o alcance desse dispositivo é restrito a casos em que haja transferência de tecnologia, expertise ou know-how ao recipiente dos serviços, como é o caso dos acordos com EUA, Reino Unido e Singapura. ${ }^{157}$

A previsão de tax sparing nos acordos de bitributação faz-se presente em alguns deles. ${ }^{158}$ Em todo o caso, o tax sparing é visto pela Índia como um mecanismo promotor e necessário ao desenvolvimento, na medida em que se enquadra como país em desenvolvimento. ${ }^{159}$ Apesar disso, a Índia foi o $14^{\circ}$ principal destino para IED em 2010. Um resultado que poderia ser melhor, não se ressentisse da queda de investimentos na Ásia ocidental, que colaboraram para que recuasse cerca de US\$11 bilhões, em comparação com 2009. ${ }^{160}$

A rede de acordos de bitributação da Índia expandiu-se, significativamente, a partir de 1999. Contudo, não se pode apontar uma orientação específica que a tenha conduzido à escolha dos parceiros, salvo a intenção de ampliar relações de comércio e investimento. Em sua recente atuação, a Índia tem se preocupado em incluir cláusulas LOB e dispositivos de assistência mútua para arrecadação de tributos, conformando-se, nesses temas, à voga internacional. ${ }^{161}$ Antes da decisão da Suprema Corte em Union of India v. Azadi Bachao Andolan (07/10/2003), a política indiana de negociação de acordos não se ocupava da inclusão de cláusulas de limitação de benefícios nas convenções, o que se alterou radicalmente, com vistas a evitar o treaty shopping.

O escopo pessoal dos acordos indianos não se afasta do modelo OCDE, assim como o escopo material, cobrindo os impostos sobre renda e fortunas (acordos antigos). Quanto às regras de distribuição de competência, a Índia segue, quase uniformemente, o modelo ONU. Do mesmo modo, nos acordos indianos, o artigo sobre EP segue o

\footnotetext{
${ }^{157}$ Cf. S. Gupta, Índia, p. 226. Este caso relembra a posição do Brasil, ao tentar favorecer a tributação na fonte em casos de remuneração por serviços técnicos no seio do acordo com a Alemanha, qualificando-os como outros rendimentos (artigo 21 do modelo OCDE), a menos que houvesse prova da transferência de tecnologia. V. M.O.Castelon, Perspectivas de novo acordo Brasil-Alemanha, p.160.

${ }^{158}$ Exemplos de acordos com tax sparing: Austrália (1991), Chipre (1994), Indonésia (1987), japão (1989), Ilhas Maurício (1982), Malta (1984), Sri Lanka (1982) e Reino Unido ( 1993). Cf. S. Gupta, Índia, p. 227

${ }^{159}$ Cf. S. Gupta, Índia, p. 235.

${ }^{160}$ Cf. UNCTAD, World Investment Report 2011, p. 4.

${ }^{161}$ Antes da decisão da Suprema Corte em Union of India v. Azadi Bachao Andolan (07/10/2003), a política indiana de negociação de acordos não se ocupava da inclusão de cláusulas de limitação de benefícios nas convenções, o que se alterou radicalmente, com vistas a evitar o treaty shopping, após a referida decisão. Cf. K. Susarla, Country Analyses: India. In: International Bureau of Fiscal Documentation Tax Research Plataform, 7.4.1.6.1. Disponível em www.ibfd.org. Acesso em 18 dez 2011.
} 
modelo ONU, restando o conceito bastante ampliado. ${ }^{162}$ Nos acordos com Austrália, Canadá e EUA, considera-se um EP de serviços, mesmo que os serviços sejam prestados na índia por apenas um único dia. ${ }^{163}$

Os rendimentos como dividendos, juros, royalties ${ }^{164}$ e remuneração por serviços técnicos estão sujeitos à tributação na fonte, quase na integralidade dos casos, a $10 \%$. Outros rendimentos são, geralmente, tributados na residência. Para evitar a bitributação, a Índia utiliza o método do crédito. ${ }^{165}$

Quanto à não-discriminação, a legislação doméstica da Índia prevê menores alíquotas para empresas indianas do que para estrangeiras. Todavia, não predomina a idéia de discriminação, pois as primeiras submetem-se a um imposto sobre a distribuição de dividendos, enquanto as estrangeiras não se sujeitam à tributação na remessa de lucros obtidos na Índia para seu Estado de residência. ${ }^{166}$

Em geral, os acordos indianos prevêem dispositivos sobre troca de informações e assistência mútua para arrecadação. Do mesmo modo, regram sobre a solução de controvérsias com o texto das convenções por meio de MAPs. ${ }^{167}$

A revisão do modelo OCDE de 2008 e seus comentários trouxeram, pela primeira vez, a posição da Índia. Os acordos indianos não dispõem de modelo próprio, embora a Índia persiga o predomínio da fonte, havendo algumas peculiaridades em sua política de negociação. A tendência indiana, em síntese, é de incluir cláusulas LOB e anti-abuso, de troca de informações e de tax sparing. ${ }^{168}$

\section{III.2.3.6 México}

\footnotetext{
${ }^{162} \mathrm{Na}$ verdade, a legislação indiana utiliza o conceito de conexão de negócios (business connection), que equivale ao de estabelecimento permanente, embora não lhe seja idêntico. A conexão de negócios tem alcance mais amplo que o EP, bastando, para sua configuração, que haja negócios na jurisdição indiana real e intimamente conectados à atividade de um não-residente (indivíduo ou empresa) e que este receba renda por meio dessa conexão. CF. SUSARLA, Kamesh. Country Analyses: India. In: International Bureau of Fiscal Documentation Tax Research Plataform, 7.1.2.1.1. Disponível em www.ibfd.org. Acesso em $18 \mathrm{dez} 2011$.

163 Cf. K. Susarla, Country Analyses: India. In: International Bureau of Fiscal Documentation Tax Research Plataform, 7.1.2.2. Disponível em www.ibfd.org. Acesso em 18 dez 2011.

${ }^{164} \mathrm{O}$ conceito de royalties é amplo nos acordos indianos, englobando o pagamento por uso de equipamento industrial, comercial ou científico tributável na fonte. Cf. S. Gupta, Índia, p. 234.

${ }^{165}$ Serão tidos por EP os trabalhos de supervisão em conexão com canteiro de obras ou projetos de construção se se demorarem mais do que um período de 6 a 12 meses. Do mesmo modo, os serviços prestados por empregados ou outras pessoas no Estado da fonte se tais serviços excederem um período variável entre 90 e 183 dias em 12 meses. Cf. S. Gupta, Índia, pp. 232-234.

${ }^{166}$ Cf. S. Gupta, Índia, p.236.

${ }^{167}$ Cf. S. Gupta, Índia, pp.237-238.

${ }^{168}$ Cf. S. Gupta, Índia, p.239
} 
A história mexicana nos acordos de bitributação começa bem depois da brasileira, somente em 1991, quando da assinatura de um tratado com o Canadá. Entretanto, as negociações passaram a se concretizar com grande celeridade após a integração do México ao NAFTA, o acordo de livre comércio da América do Norte, ${ }^{169}$ já que passou a ter como parceiros os EUA e o Canadá para questões relativas a comércio, investimento e tributação. ${ }^{170}$

O México tem uma disposição geográfica favorável aos fluxos de comércio e investimento. Localizado entre a Ásia e a Europa, o País faz fronteira com EUA. Procurando beneficiar-se dessa vantagem, o México implantou uma política de acordos bem orientada, escolhendo seus parceiros, em primeiro lugar, conforme sua rede de acordos de livre comércio. Assim, concretizou arranjos bilaterais para eliminar a bitributação com os integrantes do NAFTA, da UUEE, além de Israel, Chile e Japão países ou blocos com quem já firmara acordos de livre comércio. Em segundo lugar, o México buscou países significativos em termos de fluxos de investimento, tais como Cingapura, Coréia, Israel, China, Rússia e Brasil. ${ }^{171}$

Atualmente, a política está em uma terceira fase em que a escolha dos parceiros pode não ser muito clara. Entretanto, a condução da política de acordos tributários mexicana tem sido vigorosa, com o objetivo definido de levar o País a conquistar maior participação no cenário econômico internacional.

Segundo a Subsecretaría de Ingresos do Servicio de Administración Tributaria do México, o País se encontra em fase de negociação de acordos de bitributação com 24 jurisdições, ${ }^{172}$ enquanto aguarda a vigência de outros 6 já firmados. ${ }^{173}$ Em vigor, no entanto, o País dispõe de 42 acordos de bitributação. ${ }^{174}$ Além disso, o México já celebrou acordos para troca de informações (TIEAS) com 11 outras jurisdições. ${ }^{175}$

\footnotetext{
${ }^{169}$ North American Free Trade Agreement.

170 BALLINA, Rodrigo Gómez. México. In: LANG, Michael (Ed.). Recent tax treaty developments around the globe. Series on International Tax Law Univ - Prof. Dr. Michael Lang ( Ed.). Vol. 59. Viena: Linde Werlag Wien Ges.m.b.H., 2009, p. 293.

${ }^{171}$ Atualmente o México está em fase de negociação com os seguintes países: Cf. R. G. Ballina, México, p. 295.

${ }^{172}$ A saber: Eslovênia, Hong Kong, Letônia, Líbano, Lituânia, Malásia, Malta, Marrocos, Nicarágua, Paquistão, Qatar, Tailândia, Turquia e Ucrânia. Maiores informações em www.sat.gob.mx.

${ }^{173}$ Bahrein, Colômbia, Hungria, Kuwait, Peru e Venezuela. www.sat.gob.mx.

174 África do Sul, Alemanha, Argentina, Austrália, Áustria, Barbados, Bélgica, Brasil, Canadá, Coréia, Chile, China, Cingapura, Dinamarca, Equador, Espanha, EUA, Finlândia , França, Grécia, Índia, Indonésia, Irlanda, Islândia, Israel, Itália, Japão, Luxemburgo, Noruega, Nova Zelândia, Países Baixos, Panamá, Polônia, Portugal, Reino Unido, Rep. Checa, Rep. Eslovaca, Romênia, Rússia, Suécia, Suíça e Uruguai. Dados atualizados até outubro de 2011. Maiores informações em www.sat.gob.mx.

175 Cf. OCDE, Exchange of Tax Information Portal, Disponível em: http://www.eoitax.org/jurisdictions/MX\#agreements. Acesso em 15 nov 2011.
} 
O México tem concluído seus acordos em conformidade com o modelo OCDE, salvo pelos artigos 5 - em que reduz o tempo para qualificação de uma construção como EP de 12 para 6 meses- e 21 - outros rendimentos-, em que preponderam o modelo ONU. Exceções são os acordos com os EUA, que segue o modelo norte-americano, e com a Índia, que seria híbrido, ao modelar-se pela referência da ONU e da OCDE. ${ }^{176}$

No acordo com os EUA, que foi renegociado em 2002, não há retenção de imposto na fonte por ocasião da remessa de dividendos pagos por subsidiárias mexicanas ou norte-americanas para suas controladoras no exterior.

O México também renegociou o acordo com a Alemanha em 2008. As regras de distribuição de competência sobre dividendos e royalties foram mantidas do acordo preliminar de 1993, mas houve redução da alíquota em remessas de juros para bancos do outro signatário de $10 \%$ para $5 \%$. A cláusula de matching credit antes vigente, como era de se esperar, foi eliminada. ${ }^{177}$

Quanto à estrutura dos acordos mexicanos, cumpre lembrar que o México foi o primeiro Estado latino-americano a se tornar membro da OCDE, de modo que seguirá o modelo desta última com alguns desvios típicos de sua condição de PED. ${ }^{178}$ Assim, em geral, apresenta o mesmo escopo pessoal do artigo 1(pessoas cobertas) e 4 (residência), com algumas exceções quanto à solução do problema da dupla residência, para o qual prevê a adoção de MAP, desprezando o local da direção efetiva como tie-braker rule, em alguns tratados ${ }^{179}$.

A política mexicana não prioriza cláusulas LOB, que figuram em poucos acordos, como EUA, Canadá, Israel, Repúblicas Tcheca e Eslovaca. ${ }^{180}$ Prevê, todavia, outras cláusulas anti-elisão, que podem variar de subject-to-tax, para entidades transparentes, até permissão para aplicar direito interno por regras CFC ou de subcapitalização. ${ }^{181}$ Do mesmo modo, o tax sparing parece não ser prioritário, pois somente consta de 6 acordos mexicanos: Canadá, Coréia, Espanha, Itália, Singapura e Suíça. ${ }^{182}$

\footnotetext{
${ }^{176}$ Cf. R. G. Ballina, México, p. 296.

${ }^{177}$ Cf. R. G. Ballina, México, p. 298.

${ }^{178}$ ROBLES, Arturo Pérez. Country Analyses: Mexico. In: International Bureau of Fiscal Documentation Tax Research Plataform, 7.4.1.1. Disponível em www.ibfd.org. Acesso em 17 dez 2011.

${ }^{179}$ Cf. R. G. Ballina, México, p. 299.

${ }^{180}$ Cf. A.P.Robles, Country Analyses: Mexico. In: International Bureau of Fiscal Documentation Tax Research Plataform, 7.4.1.6.1. Disponível em www.ibfd.org. Acesso em 17 dez 2011.

${ }^{181}$ Cf. R. G. Ballina, México, p. 300.

182 Cf. A.P.Robles, Country Analyses: Mexico. In: International Bureau of Fiscal Documentation Tax Research Plataform, 7.4.1.6.2. Disponível em www.ibfd.org. Acesso em 17 dez 2011.
} 
Materialmente, convenções mexicanas não se afastam do artigo 2 (tributos cobertos) do modelo OCDE. Em suas regras distributivas, da mesma forma, poucos são os desvios do modelo OCDE, merecendo registro, o tratamento dos royalties (artigo 12) e dos outros rendimentos (artigo 21), por seguirem o modelo ONU, ou seja, ao invés de conferirem competência exclusiva para residência, repartem a competência para que a fonte também exerça sua pretensão sobre tais rendimentos. ${ }^{183}$

O método escolhido pelos mexicanos para evitar a bitributação é o método da imputação, havendo pouquíssimos acordos com a previsão cumulativa do método da isenção. Praticamente todos os acordos firmados a partir de 1999 dispõem de cláusula de não-discriminação, troca de informações e MAPs. ${ }^{184}$

A escolha mexicana por expandir sua rede de acordos de bitributação parece coerente com seu objetivo de inserção internacional. O México, que não tem par na América Latina neste quesito, deverá continuar em ritmo forte, concluindo novos acordos. Porém, na fase atual, o País também passa a ser visto como um exportador de capital, de modo que, em sua política de acordos tributários, não tem negligenciado países da América Latina e do Oriente Médio.

A fim de atrair mais IED, o México parece ter optado, prioritariamente, pela credibilidade e estabilidade de suas normas tributárias e seus resultados são auspiciosos, pois conseguiu a $18^{\mathrm{a}}$ posição como maior destino de IED no mundo, em $2010 .^{185}$

\section{II.2.3.7 Brasil}

No caso brasileiro, a política desenvolvida na assinatura dos acordos alterou-se com o decorrer do tempo e o momento econômico. Quatro fases poderiam ser diferenciadas, a saber: ${ }^{186}$

\footnotetext{
${ }^{183}$ Cf. R. G. Ballina, México, pp. 304-306.

${ }^{184}$ Há previsão na Constituição Mexicana e nas leis domésticas do México permitindo autoridades a solicitarem dos contribuintes quaisquer informações relevantes no escopo dos acordos internacionais, que poderão inclusive, ser entregues a autoridades estrangeiras. Do mesmo modo, há previsão doméstica autorizativa para arrecadar tributos em benefício de outro Estado, conforme art. 4 do Código Fiscal federal do México. Cf. R. G. Ballina,, México, p. 309.

${ }^{185}$ Cf. UNCTAD, World Investment Report 2011, p. 4.

186 SCHOUERI, Luís Eduardo. Contribuição à história dos acordos de bitributação: a experiência brasileira. In: COSTA, Alcides Jorge; SCHOUERI, Luís Eduardo e BONILHA, Paulo Celso Bergstrom (coord.), Direito Tributário Atual 22. São Paulo: Dialética, 2008. pp. 276-277.
} 
(i) $1^{a}$ fase, anos 60 e 70: essa etapa inicial marcou a busca brasileira por parceiros desenvolvidos e pela inclusão de cláusulas de incentivo como tax sparing e matching credit;

(ii) $2^{a}$ fase, anos 80: esse período marcou a divisão da negociação brasileira entre PD e PED. Com os primeiros, o Brasil insistia nas cláusulas de incentivo, que não eram relevantes nos acordos com os últimos. Ainda assim, três acordos foram firmados com cláusulas recíprocas de matching credit (Índia, Filipinas e Coréia do Sul);

(iii) $3^{a}$ fase, anos 90: pouquíssimos acordos foram firmados nessa etapa, apenas Países Baixos (1990), China (1991) e Finlândia (1996); e

(iv) $4^{a}$ fase, de 2002 até os dias atuais: severas mudanças na ordem econômica alteraram o status de tradicional importador de capital do Brasil, que começa a investir mais substancialmente no exterior. Novo acordos foram assinados com países que não eram investidores tradicionais e nem mantinham relação regional: Israel (2002), Ucrânia (2002), México (2003), África do Sul (2003), Rússia (2004), Venezuela (2005), Peru (2006), Trinidad e Tobago (2008) e Turquia (2010). ${ }^{187}$

O primeiro acordo negociado brasileiro foi com a Suécia, por ocasião do regime militar, em 1965, ${ }^{188}$ ocasião em que o Brasil tinha interesse em garantir incentivos fiscais a investidores estrangeiros com o propósito de atraí-los. Havia uma aura desenvolvimentista a ser conseguida pela intervenção direta e pela indução. ${ }^{189}$

Na seqüência, o acordo com o Japão ${ }^{190}$ já previa uma definição mais ampla para estabelecimentos permanentes, divergindo da convenção modelar da OCDE não só por incluir o depósito no rol dos EP, como por reduzir de 12 para 6 meses o tempo necessário para a qualificação de um canteiro de obras como tal. O Brasil também divergiu da OCDE por não reduzir sua tributação sobre rendimentos passivos ao nível

\footnotetext{
187 Já firmados, porém ainda não em vigor, os acordos brasileiros com Rússia, Venezuela, Trinidad e Tobago e Turquia. Cf. OCDE, Exchange of Tax Information Portal. Disponível em: http://www.eoitax.org/jurisdictions/BR\#agreements. Acesso em 15 nov 2011.

${ }^{188}$ O Brasil mantém acordos de bitributação com os seguintes países: África do Sul, Argentina, Áustria, Bélgica, Canadá, Chile, China, Coréia, Dinamarca, Equador, Espanha, Filipinas, Finlândia, França, Hungria, Índia, Israel, Itália, Japão, Luxemburgo, México, Noruega, Países Baixos, Peru, Portugal, República Eslovaca, República Tcheca, Suécia e Ucrânia. Cf. Receita Federal do Brasil. Dados disponíveis em http://www.receita.fazenda.gov.br/legislacao/acordosinternacionais/acordosduplatrib.htm. Acesso em 08 nov 2011.

${ }^{189}$ Cf. L.E Schoueri. Contribuição à história dos acordos de bitributação: a experiência brasileira, pp. 267-269.

${ }^{190}$ Dec. $61.899 / 67$.
} 
por ela recomendado, ${ }^{191}$ mantendo uma alíquota geral de $15 \%$ na maioria dos acordos, ressalvada a alíquota de $12,5 \%$ no acordo com o Japão. ${ }^{192}$

Para se ter uma idéia, a tributação na fonte de dividendos, juros e royalties prevista nos acordos brasileiros com os países analisados neste capítulo, estaria limitada da seguinte forma: ${ }^{193}$

\begin{tabular}{|c|c|c|c|}
\hline Acordo & Dividendos & Juros & Royalties \\
\hline Brasil-Chile & $\begin{array}{l}10 \% \text { (participação } \\
\text { direta mínima de } \\
25 \% \text { ); e } \\
15 \% \text { demais casos }\end{array}$ & $15 \%$ & $15 \%$ \\
\hline Brasil-China & $15 \%$ & $15 \%$ & $\begin{array}{l}25 \% \text { (uso ou direito } \\
\text { de uso de marcas de } \\
\text { indústria } \\
\text { comércio); e } \\
15 \% \text { demais casos }\end{array}$ \\
\hline Brasil- Índia & $15 \%$ & $15 \%$ & $\begin{array}{l}25 \% \text { (uso ou direito } \\
\text { de uso de marcas de } \\
\text { indústria } \\
\text { comércio); e } \\
15 \% \text { demais casos }\end{array}$ \\
\hline Brasil- México & $\begin{array}{l}10 \% \text { (participação } \\
\text { direta mínima de } \\
20 \% \text { ); e } \\
15 \% \text { demais casos }\end{array}$ & $15 \%$ & $15 \%$ \\
\hline
\end{tabular}

O Brasil tem negociado um conceito abrangente de royalties, incluindo serviços técnicos e assistência técnica. Entretanto, os poucos serviços que não estejam cobertos pelo artigo 12 da convenção (royalties), segundo o entendimento brasileiro, devem ser

${ }^{191}$ O Modelo OCDE limita a tributação na fonte da seguinte forma: (i) dividendos: $5 \%$ se o beneficiário efetivo detiver participação direta mínima de $25 \%$ na empresa que paga os dividendos; $15 \%$ nos demais casos; (ii) juros: 10\%; e (iii) royalties: zero (competência exclusiva da residência).

192 Cf. L.E Schoueri. Contribuição à história dos acordos de bitributação: a experiência brasileira, p.p 273 e 275. A alíquota de 12,5\% representava a metade da usual de $25 \%$ à época. Essa limitação foi resultante do Protocolo que modificou o acordo Brasil-Japão, promulgado pelo Decreto no 81.194, de 9 de janeiro de 1978.

${ }^{193}$ O quadro não contempla a Alemanha e os EUA por não terem acordo de bitributação em vigor com o Brasil. 
enquadrados no artigo 21 (outros) e não no artigo 7, que é a cláusula geral dos lucros. Dessa forma, a competência seria repartida, permitindo a tributação brasileira, o que não ocorre pelo art. 7, em que a tributação fica somente a cargo da residência. Essa visão merece toda sorte de críticas pelos riscos de bitributação que suscita, o que, para o investidor estrangeiro, não é nada encorajador. ${ }^{194}$

Schoueri vê o Brasil como bom negociador, pois fez valer sua vontade política beneficiando-se nos seguintes itens: ${ }^{195}$

(i) tributação na fonte para juros, dividendos e royalties em níveis superiores ao recomendado pela OCDE;

(ii) ampliação do conceito de royalties e de EP;

(iii) cláusulas de incentivo: matching credit e tax sparing;

(iv) tributação de outros rendimentos (geralmente superior aos rendimentos especificados na convenção)

Apesar de ter feito prevalecer seus interesses em acordos de bitributação, fato é que a rede construída pelo Brasil ainda é bastante tacanha se comparada com seus concorrentes emergentes. O Brasil tem somente 29 acordos em vigor, acrescendo-se mais 1 acordo para cooperação e troca de informações em matéria tributária (TIEA com os EUA). É realmente muito pouco para quem pretende aumentar sua inserção na ordem internacional como pólo de atração ao IED.

\section{III.3 CONCLUSÕES DO CAPÍTULO}

\footnotetext{
${ }^{194}$ Cf. L.E Schoueri. Contribuição à história dos acordos de bitributação: a experiência brasileira, p. 276.

${ }^{195}$ Cf. L.E Schoueri. Contribuição à história dos acordos de bitributação: a experiência brasileira, pp. 280-281.
} 
III.3.1. O Estado competitivo pós-moderno dispõe da norma tributária indutora enquanto instrumento útil para enfrentar a concorrência internacional e lograr êxito na atração do IED. Ocorre que a desoneração tributária que somente aproveite ao investidor estrangeiro, sem benefício à coletividade do Estado indutor não se conforma ao Estado de Direito. Assim, a concessão de benefícios fiscais, gênero de auxílios concedidos aos contribuintes pela via tributária -incentivos fiscais ou tributários- ou financeira - transferências diretas ou subvenções (stricto sensu), deve submeter-se aos ditames da Constituição para serem válidos.

III.3.2. Sob a óptica jurídica, as subvenções não se confundem com incentivos fiscais, já que pressupõem um desembolso real, visível, na previsão e na execução orçamentárias. Os incentivos fiscais, por seu turno, resultam da renúncia na via das receitas, reduzindo a arrecadação, de modo que o Estado abdica de receitas que, salvo por tais incentivos, deveria, normalmente, recolher a seus cofres. O desafio do Estado reside em induzir o comportamento do investidor externo sem descurar do controle eficaz dos incentivos fiscais, não só por resguardar o equilíbrio das contas públicas, mas pelo dever de transparência que deve à sociedade. A dificuldade no controle dos incentivos não se encontra na via da despesa, pelas transferências diretas registradas no orçamento, mas na via das receitas, onde os gastos tributários desfalcam a estimativa de receitas orçamentárias.

III.3.3 Dificuldades surgem, ainda, para a medição dos gastos tributários, cujo controle reside em um problema quanto a definir o que seria a estrutura do imposto -parâmetro. Independente de controvérsias conceituais, o fato de o controle sobre gastos ser exercido pela maioria dos países, somado ao fato de que o Brasil começou sua medição somente após a estabilização monetária e, ainda, que a aferição de tais gastos é uma exigência constitucional, importa que esse controle seja efetivo, baseado em um critério cuja aplicação seja uniforme e que produza, com clareza, o resultado dos custos suportados pelos contribuintes pagadores. Somente assim será possível avaliar se se trata ou não de medida proporcional e, conseguintemente, constitucional.

III.3.4. Em ambiente de concorrência, diversos países oferecem incentivos, de modo que não oferecê-los pode significar perda de investimentos e receitas tributárias. Entretanto, o indesejável é que as normas tributárias indutoras fiquem, somente, sob a guarda de 
interesses políticos obscuros, sem que sejam demonstrados os resultados por elas produzidos. Isso porque elas representam um custo que deve ser, forçosamente, menor que os benefícios que produzir. Meros argumentos abstratos sem comprovação objetiva, a nosso ver, afastam os efeitos positivos que delas se poderiam obter.

III.3.5. O crescimento recente dos gastos tributários brasileiros contribuíram para que o imposto de renda fosse renunciado em $40 \%$ do seu total em 2010. Há determinadas áreas do orçamento financiadas, integralmente, pelos gastos tributários, sem que se despenda um centavo sequer na consecução dos programas previstos. A continuar nessa tendência, as despesas públicas teriam seu futuro comprometido. Transparência e boa-fé objetiva precisam ser, efetivamente, postos em prática para afastar suspeitas de ilegitimidade sobre os gastos tributários. A participação do setor privado na consecução de objetivos constitucionalmente previstos nas áreas sociais e econômicas, é altamente desejável, especialmente após ter declinado o Welfare State. Todavia, tal atuação não pode prevalecer de forma absoluta no Estado de Direito. Não se pode concluir pela constitucionalidade de gastos tributários que não comprovem observância dos critérios informadores das ordens tributária e econômica, mensurados pelo exame de proporcionalidade.

III.3.6. Considerando a criação de bom ambiente aos fluxos de IED e a desejável participação do setor privado na consecução de objetivos sócio-econômicos previstos pela $\mathrm{CF}$, o controle dos gatos tributários deve ser realizado sob mediante a aplicação de critérios claros, uniformemente aplicados, de modo a não criar distorções sobre a atuação dos agentes econômicos. Assim, o legislador estará conforme às exigências do ordenamento jurídico.

III.3.6. Na pós-modernidade, os acordos de bitributação têm por meta eliminar ou minorar os riscos de bitributação, prevenir a evasão fiscal, conferir certeza e segurança jurídica e estimular o comércio internacional. Todavia, podem também ser utilizados com a finalidade de atrair IED, produzindo, ainda, efeitos indiretos relevantes como atração de tecnologia e know-how, geração de empregos, capacitação de mão-de-obra e outros. Historicamente, os acordos de bitributação têm diferenciado, em sua estrutura e técnica, países exportadores de capital e países importadores de capital. A dicotomia 
fonte (PEDs) X residência (PDs) é uma das causas principais da bitributação e está consagrada nos dois principais modelos de convenção - OCDE e ONU.

III.3.7. A fim de garantir um ambiente favorável ao investidor estrangeiro, é importante construir uma extensa rede de acordos, já que esta confere maiores possibilidades de comércio e investimentos internacionais. O planejamento e a execução de uma política de acordos tributários exige estudo mais aprofundado do cenário internacional e das medidas adotadas pelos interlocutores. Tradicionalmente, a segunda metade do século XX assistiu a negociações bilaterais em que a fonte priorizou cláusulas de incentivo como tax sparing ou matching credit, por meio das quais a residência não tributaria (ou o faria a menor que o disposto em suas normas) seu investidor beneficiado pelos incentivos fiscais concedidos na fonte. Atualmente, parece difícil garantir a manutenção do crédito de imposto pela via das cláusulas de incentivo, pois a residência tem de aceitar custear a política de indução praticada pela fonte. Tanto assim é, que países desenvolvidos têm buscado renegociar acordos dispondo sobre essas cláusulas. Exemplo disso são a Alemanha (acordo denunciado em 2005), Holanda e os países nórdicos que já sinalizaram neste sentido com o fisco brasileiro.

III.3.8. Defendendo alterações no cenário internacional, a OCDE questionou o tax sparing quanto à sua eficiência na atração do IED, pois que a eles corresponderia renúncia de receitas pela fonte. Outros fatores foram levantados, igualmente, como complexidade, fomento à concorrência tributária; ineficácia da tributação em atrair o investidor atento a outros fatores econômicos, políticos e sociais; melhora econômica dos PED; e efeitos perniciosos do lobbying pela proliferação de concessões a diversos setores da economia.

III.3.9. Uma reconsideração da posição da OCDE sobre o tax sparing, entretanto, foi recentemente proposta pelo Professor da Faculdade de Direito da USP, Luís Eduardo Schoueri, sustentando, em síntese, que não há evidência empírica de maus resultados pelo uso do tax sparing; embora o efeito carona seja indesejável não se pode por eles concluir que os acordos seriam prejudiciais ao investimento; baixa tributação na fonte como resultado da negociação do tax sparing não parece um argumento convincente, pois a posição da OCDE tem sido manifestada reiteradamente neste sentido, de modo que seria crucial que essa organização revisse sua posição quanto à fonte; aumento do 
padrão de vida dos PED não é uniforme, havendo países realmente necessitados de estímulo ao crescimento; e potencial de abuso estaria em todos os dispositivos dos acordos e não somente na cláusula de tax sparing.

III.3.10. A política de acordos tributários de alguns países concorrentes ou interlocutores do Brasil merece análise mais detida. China e Índia como representantes dos BRIC; Chile e México pela América Latina; e Alemanha e EUA enquanto representantes dos PD com os quais o Brasil mantém estreitas relações comerciais. Pode-se concluir, ao serem comparadas as políticas empreendidas pelos acordos de bitributação, que os PED, em sua maioria, tentaram ou ainda tentam negociar cláusulas de incentivo, embora essa estratégia tenha sido mais agressiva até os anos 90. Surpreende, porém, que o Brasil tenha começado a negociar acordos dessa natureza há meio século e ainda não possua 30 acordos em vigor, quando seus concorrentes sob análise - BRIC ou latino-americanos-, já possuam uma rede bem mais extensa, muitos deles iniciando suas negociações décadas após o Brasil. A inércia brasileira não é justificável, especialmente pela segurança e clareza que os acordos de bitributação ofertam aos investidores.

III.3.11. A despeito de o País ter se mostrado bom negociador, fazendo valer suas intenções no caso concreto, a política brasileira de acordos tributários precisa ser modificada para atender às exigências do ordenamento pátrio. Fixar a boa ambiência ao investidor, como uma das vias de garantir o desenvolvimento, é obrigação a que se vêem compelidas as autoridades públicas. Destarte, uma extensa rede de acordos de bitributação conferiria maior segurança a investidores de diferentes jurisdições do que uma restrita. Adicionalmente, a depender do interlocutor, o Brasil poderia negociar o tax sparing com países tradicionalmente exportadores de capital ou mesmo prever uma cláusula de aplicação mútua com países que, como o nosso, também visem a investir no estrangeiro. 


\section{CAPÍTULO IV- TRIBUTAÇÃo DA RENDA E COMPETITIVIDADE INTERNACIONAL}

\section{IV.1 MOLDURA CONSTITUCIONAL DA RENDA NO BRASIL}

\section{IV.1.1 Conceito de renda}

O imposto de renda é visto como uma espécie de elevada integridade, carregando as condições mais apropriadas para a observância da capacidade contributiva em suas duas facetas: objetiva e subjetiva. ${ }^{1}$ Sob esta óptica, a renda seria uma base altamente confiável para o Estado de Direito, cujo ordenamento tributário se deve vincular à busca da justiça pelas veredas prioritárias da igualdade. Desvios de percurso, portanto, devem ser bem justificados, como no caso de normas tributárias indutoras sob guarida da proporcionalidade e demais previsões pontuais desde que não excessivamente custosas ao tratamento isonômico que se espera do Estado.

O objetivo de alcançar a renda como base de tributação não é dos mais fáceis, pois cabe ao Estado bem definir seus contornos ante conceito aberto, que, visto sob diferentes prismas, dificilmente produzirá resultados similares. Em outro giro, é conferida ao legislador uma ampla - mas não absoluta - liberdade de escolha de critérios para a definiçãa de renda e, a depender dessas escolhas, o regime de tributação da renda resultante dificilmente encontrará identidade no contexto das ordens nacionais.

A tarefa de definir a renda para fins de tributação pode ser ilustrada na comparação entre uma economia interdependente e uma economia de escambo. $\mathrm{Na}$ primeira, enquanto meio de sobrevivência das pessoas, a renda tributável poderia ser identificada pelo dinheiro; enquanto na segunda, por alguma forma não-monetária. A conclusão é que sem renda sequer pode haver economia. ${ }^{2}$

\footnotetext{
${ }^{1}$ Cf. K. Tipke e J. Lang, Direito tributário (Steuerrecht), pp. 448-449.

${ }^{2}$ HOLMES, Kevin. The concept of income - a multidisciplinary analysis. Amsterdam: IBFD, 2001, p. 4. Fernando Zilveti, baseado na obra de García Belsunce, apresenta a evolução do conceito de renda desde 1850, com Biersack - "todos os ganhos que fluem do exercício do poder produtivo do indivíduo" - até 1962, quando Valdés Costa sustentou que "renda é aquilo que a lei define como tal e não deve estar necessariamente ligada à concepção econômica ou jurídica, porém acata a função produtiva e, por outro lado, exclui a idéia de periodicidade", perpassando por diversas posições influenciadas pelo avanço social, econômico, político e científico da humanidade. Outros tantos se manifestaram sobre a renda, destacando-se Herman (1874), Schanz (1896), Neumann (1899), Fisher (1906), Seligman (1911), Haig (1921), Griziotti (1931), Simons (1938), Einaudi (1940), Vanoni (1945), Rubens Gomes de Souza (1950) e Jarach (1958). ZILVETI, Fernando Aurélio. O princípio da realização da renda. In: SCHOUERI, Luís Eduardo (org.). Direito tributário - homenagem a Alcides Jorge Costa, v. 1. São Paulo: Quartier Latin, 2003, p. 300-303.
} 
Prevaleceu, na teoria econômica inicial, um ideal subjetivista, do qual resultaria a proposta de vincular renda ao bem-estar. ${ }^{3}$ Nesse contexto, o imposto deveria alcançar os contribuintes tanto mais, quanto maior seus índices de conforto e bem-estar. Aqui está a gênese da idéia de renda psíquica, por meio da qual, a renda deveria traduzir os bem-estares psicológicos dos sujeitos passivos.

A tributação da renda baseada no bem-estar levou à construção da teoria da tributação ótima (optimal tax theory), que tomaria características pessoais do sujeito passivo para medir sua capacidade contributiva. O equívoco desta teoria reside na impossibilidade de identificação e medição de atributos pessoais - educação, capacidade intelectual, expectativa de vida - para determinar o grau de bem-estar (renda tributável) do contribuinte. Em termos práticos, legislador e autoridades fazendárias estariam compelidos a superar abstrações e complexidades quiçá insuperáveis. ${ }^{4}$

Num contexto coletivo, o bem-estar de toda a sociedade exigiria a redistribuição de riquezas por entre seus integrantes. Logo, a renda poderia ser tributada para a promoção deste fim, atendendo aos princípios da igualdade e da justiça. ${ }^{5}$

No âmbito da common Law, o processo de conceituação de renda também enfrentou óbices. Segundo Martin Burke e Michael Friel, naquele contexto, o conceito de renda dependeria do exame das influências recíprocas entre propósito parlamentar, metas administrativas, conceitos contábeis e políticas públicas definidas pelo Congresso, Judiciário e Fisco. ${ }^{6}$

Nos EUA, a 1913 Tax Act já definia renda como gains or profits and income derived from any source. Todavia, em Glenshaw Glass (1955), ${ }^{7}$ a Suprema Corte entendeu pela insuficiência dessa definição legal para englobar todas as situações que o conceito de renda sugere. Na verdade, a Suprema Corte já havia definido renda no caso Eisner v. Macomber (1920). ${ }^{8}$ Considerando a atuação do Fisco no mesmo esforço, o que fora feito pelos seus Regulations, pode-se concluir que o conceito de renda foi

\footnotetext{
${ }^{3}$ Em 1909, Richard Ely, em seu Outlines of Eocnomics, Macmillan, New York, p. 98, teve ocasião de escrever: "real income....has reference to the satisfaction which we derive from the use of material things or personal services during a period of time." Cf. K. Holmes, The concept of income - a multidisciplinary analysis, p. 36.

${ }^{4}$ Cf. K. Holmes, The concept of income - a multidisciplinary analysis, pp. 6 e 9.

${ }^{5} \mathrm{Cf}$. K. Holmes, The concept of income - a multidisciplinary analysis, p. 31.

${ }^{6}$ BURKE, J. Martin.; FRIEL, Michael K. Taxation of individual income. 6th ed. NJ: LexisNexis, 2002, p. 24.

${ }^{7}$ EUA, United States Supreme Court, Commissioner v. Glenshaw Glass Co., 348 U.S. 426 (1955).

${ }^{8}$ EUA, United States Supreme Court, Eisner v. Macomber, 252 U.S. 189 (1920). A Sp. Ct. definiu renda como "The gain derived from capital, from labor, or from both combined, provided it be understood to include profit gained through a sale or conversion of capital assets...".
} 
desenvolvido, realmente, pela atuação dos três poderes através do Congresso, Judiciário e Fisco. ${ }^{9}$

Em oposição ao ideal subjetivista dos primeiros economistas, ancorado na renda psíquica, nasceu a teoria baseada no acréscimo patrimonial, cuja concepção inicial se deveu ao trabalho desenvolvido por Georg von Schanz, na Alemanha, em 1896. Posteriormente, nos EUA, o conceito proposto por Schanz foi desenvolvido por Robert Haig, em 1921, até que a ele se somasse a contribuição final ofertada por Henry Simons em 1938. O resultado desses trabalhos se tornou conhecido como Modelo SHS (SchanHaig-Simons), também denominado por conceito fundamental de renda ${ }^{10}$ ou teoria da renda como acréscimo patrimonial. ${ }^{11}$

Em síntese, o SHS é um modelo abrangente, no qual a renda reflete o aumento no poder econômico de uma pessoa em um período. Em termos práticos, seriam os acréscimos líquidos de riqueza adicionados à renda imputada ${ }^{12}$ e aos gastos com consumo em um dado período de tempo. Este modelo abrange todos os ingressos passíveis de avaliação monetária, prescindindo da conversão em moeda para a caracterização da renda. Para este fim, bastaria, portanto, o acréscimo de poder econômico desde que permita avaliação, ${ }^{13}$ o que significa abranger rendimentos ainda não realizados.

Em 1832, Herman defendeu a teoria da fonte, dotando-a da característica de periodicidade, sem abordar o aspecto da satisfação psíquica. Assim, a renda derivaria, periodicamente, de uma fonte permanente, assumindo o caráter de renda-produto.

Malgrado prevalecentes enquanto teorias econômicas para definir renda, se observadas de modo estanque, a teoria do acréscimo patrimonial e a teoria da fonte não proporcionam um conceito suficientemente abrangente de renda. A teoria da fonte, por ser muito estreita, exclui nítidos índices de manifestação de riqueza, como ganhos de capital ou quaisquer situações esporádicas por ausência do requisito da periodicidade. ${ }^{14}$

\footnotetext{
${ }^{9}$ A definição atual positivada de renda encontra-se no Internal Revenue Code, §61(a). Cf. L.M. Burke e M;K. Friel, Taxation of individual income, 26.

${ }^{10} \mathrm{Cf}$. K. Holmes, The concept of income - a multidisciplinary analysis, pp. 55-57.

${ }^{11}$ SILVEIRA, Ricardo Maitto da. O princípio da realização da renda no direito tributário brasileiro. In: COSTA, Alcides Jorge; SCHOUERI, Luís Eduardo e BONILHA, Paulo Celso Bergstrom (coord.), Direito Tributário Atual 21. São Paulo: Dialética, 2007 pp. 321.

${ }^{12}$ A renda imputada é aquela decorrente do uso dos próprios bens ou serviços desenvolvidos pelo sujeito passivo a seu benefício. Assim, os serviços gerais realizados no lar pelo proprietário que deixou de contratar um profissional representaria um valor não despendido correspondente à renda imputada. Da mesma forma os serviços domésticos realizados pela esposa ou a habitação da casa própria em que não se gasta com aluguel.

${ }^{13}$ Cf. R.M da Silveira, O princípio da realização da renda no direito tributário brasileiro, p. 321.

${ }^{14} \mathrm{Cf}$. K. Holmes, The concept of income - a multidisciplinary analysis, p. 86.
} 
Já a teoria do acréscimo patrimonial não explica a incidência do imposto sobre a remessa de rendimentos aos não-residentes, que se dá de uma só vez, impossibilitando a aferição de variação patrimonial no tempo.$^{15}$

\section{IV.1.2 O conceito constitucional de renda no Brasil}

A Constituição Federal atribui competência à União para instituir imposto sobre renda e proventos de qualquer natureza (art. 153, III), o qual será informado pelos critérios da generalidade, da universalidade e da progressividade, na forma da lei $\left(\S 2^{\circ}\right)$.

A expressão na forma da lei remete ao art.146 da Carta Magna, que evoca a lei complementar para estabelecer normas gerais em matéria de legislação tributária, especialmente sobre a definição dos fatos geradores, bases de cálculo e contribuintes dos impostos discriminados pela Constituição, dentre os quais o imposto de renda.

Se o constituinte estabeleceu um conceito de renda ou se atribuiu esta tarefa ao legislador infraconstitucional é questão controversa, que "conduz a doutrina a chegar a se separar em dois pólos opostos e extremos, um que afirma não existir um conceito constitucional de renda e proventos e outro que enxerga um conceito constitucional limitador dos trabalhos legislativos infraconstitucionais". ${ }^{16}$

Assumida a inexistência de um conceito constitucional de renda, o legislador complementar poderia trabalhar em campo aberto, valendo-se de sua competência para conceituar aquilo que a Carta Política apenas indicara como base para a incidência do imposto, ou seja, renda e proventos de qualquer natureza.

Entende-se, contudo, que assim não pode ser. Em outro plano, a discussão seria sobre a explicitação ou não do conceito de renda pela Constituição, mas não de sua imprevisão. A preferência por esta via decorre da própria obediência, devida pelo legislador, aos elementos materiais ditados pela Constituição para fazer incidir o imposto previsto no III do art. 153 - renda e proventos de qualquer natureza.

Se assim não fosse, em respeito ao princípio da igualdade enquanto pilar do Estado de Direito, inaceitável que o legislador complementar contrariasse a própria

${ }^{15}$ Cf. SCHOUERI, Luís Eduardo. O mito do lucro real na passagem da disponibilidade jurídica para a disponibilidade econômica. In: MOSQUERA, Roberto Quiroga e BROEDEL, Alexsandro (org.). Controvérsias jurídico-contábeis - aproximações e distanciamentos, p. 243. Para uma crítica às teorias do aumento do patrimônio líquido e da fonte, v. K. Tipke e J. Lang, Direito tributário (Steuerrecht), p. 470, donde se extrai que "nem a teoria da fonte nem a teoria do aumento do patrimônio líquido têm podido impor-se como conceito dogmático jurídico para todas as espécies de rendimento."

${ }^{16}$ OLIVEIRA, Ricardo Mariz de. Fundamentos do imposto de renda. São Paulo: Quartier Latin, 2008, p. 170. 
natureza das coisas para positivar como renda aquilo que não apresentasse qualquer indício de riqueza. Assim, situações desvinculadas da capacidade contributiva deveriam ser afastadas de plano da atividade legislativa que por fim tivesse a definição da hipótese de incidência do imposto.

Decorre disso que uma conceituação legalista de renda não foi recepcionada entre nós. ${ }^{17}$ Para além das clássicas teorias de gênese econômica - renda-produto e renda-acréscimo -, haveria uma tentativa jurídica de conceituar renda, cujo adágio seria renda é aquilo que a lei disser que é. Ocorre que, mesmo desconsiderando qualquer conceito constitucional de renda, não é possível conceber que lei complementar determine situações que não pertençam à classe dos elementos integrantes do conjunto renda para fins de tributação.

Ainda que não fosse possível identificar todos os elementos desse conjunto, podem-se indicar, com segurança, elementos que lá não se enquadrariam. Logo, situações como atividades físicas regulares, estilos de corte de cabelo, inclinações musicais e outras do gênero, não podem configurar renda por limitações semânticas intransponíveis. $^{18}$

Não prospera, pois, a vertente que rejeita integralmente o conceito constitucional de renda. Ainda que se conceda a mais larga liberdade possível ao legislador complementar, seu campo de atuação sofreria limites pelo valor semântico das palavras ditadas pelo constituinte. Afinal, não lhe seria dado definir renda em sentido diverso ao que, ontologicamente, ela seja. ${ }^{19}$

Parecem entender da mesma forma Ricardo Lobo Torres, para quem "renda e proventos são conceitos constitucionais abertos, que devem ser trabalhados pela

\footnotetext{
${ }^{17}$ O Ministro Nelson Jobim, em seu voto no RE 201.456-6/MG, sustentou o conceito legalista, conferindo liberdade ampla ao legislador para definir renda. Cf. STF, RE 201.456-6, Rel. Min. Nelson Jobim, DJ $17 / 10 / 03$.

${ }^{18}$ Ricardo Mariz sintetiza algumas decisões do STF que privilegiam o limite semântico dos termos grafados na $\mathrm{CF}$, a ser observado pelo legislador, para afastar a teoria legalista do ordenamento vigente. Neste sentido transcreve-se o entendimento do Min. Thompson Flores no RE 71758-GB, de 14/06/1972: "Concordo que a lei pode, casuisticamente, dizer o que é ou o que não é renda tributável. Mas não deve ir além dos limites semânticos, que são intransponíveis. Entendo, por isso, que ela não pode considerar renda, para efeito de taxação, o que é , de maneira incontestável, ônus, dispêndio, encargo ou diminuição patrimonial, resultante do pagamento de um débito." Cf. R.M. de Oliveira, Fundamentos do imposto de renda, pp.177-178.

${ }^{19}$ Apesar de não se discutir aqui sobre os limites desse conceito constitucional de renda, adota-se posição em favor de sua existência. Todavia, diga-se que a controvérsia acerca desse tema ainda se encontra acesa. Ricardo Mariz de Oliveira assevera que nenhuma das duas posições - a favor e contra a existência do conceito constitucional de renda - foi aceita de forma pacífica, não objetada pela comunidade científica. Cf.. R.M. de Oliveira, Fundamentos do imposto de renda, pp.171.
} 
doutrina e pela legislação" 20 e Humberto Ávila, ao sustentar que a "Constituição adotou expressamente um conceito amplo de renda, no qual estão abrangidos também os proventos." 21

Ávila, inclusive, vai mais além, defendendo uma conceituação expressa de renda pelo constituinte, o que teria sido feito por atuação positiva e atuação negativa. Por intermédio da primeira, o conceito de renda pressuporia uma fonte produtiva enquanto que o de proventos abrangeria todos os acréscimos patrimoniais não pertencentes ao conjunto da renda, inclusive as mais-valias ou ganhos de capital, desde que passíveis de avaliação econômica. ${ }^{22}$

Pela via negativa, seria possível chegar ao conceito de renda pela confrontação com outras hipóteses de incidência previstas pelo próprio constituinte. Como cada norma deve ter um significado próprio em atenção ao postulado da unidade da Constituição, renda não poderia ser, pura e simplesmente, patrimônio, capital, faturamento e nem lucro. Como conseqüência, o conceito amplo de renda, abrangendo também os proventos de qualquer natureza, seria o "resultado positivo entre receitas e despesas de acordo com a capacidade contributiva" medido em dado período de tempo. $^{23}$

Ocorre que, conforme lição de Luís Eduardo Schoueri, ${ }^{24}$ "nem sempre se extrai, do próprio texto constitucional, um conceito. Muitas vezes, o constituinte apenas se referiu aos impostos a partir de uma aproximação tipológica." Com efeito, conceitos e tipos são duas vias ao dispor do legislador para abstrair características da realidade e gravá-las no texto da lei.

O conceito jurídico apresenta exata definição, delimitação precisa, embora não exija a apresentação de todas as características do objeto. Bastaria a enumeração de características suficientes para individualizar o objeto sob conceituação, distinguindo-o

\footnotetext{
${ }^{20}$ Cf. RL.Torres, Curso de direito financeiro e tributário, p. 375.

21 ÁVILA, Humberto. Conceito de renda e compensação de prejuízos fiscais. São Paulo: Malheiros Editores, 2011, p. 32.

22 Não parece claro que essa delimitação positiva tenha sido efetuada de forma pura pela Constituição, pois o autor parece recorrer ao art. 43 do CTN, ao falar de renda como "o produto do capital, do trabalho ou da combinação de ambos" e de proventos como "os acréscimos patrimoniais não compreendidos no inciso anterior.” Cf. H. Ávila, Conceito de renda e compensação de prejuízos fiscais, pp.32-33.

${ }^{23}$ Diferencia-se a hipótese do imposto de renda de outras previsões constitucionais, a saber: (i) patrimônio como algo estático - arts. $145, \S 1^{\circ} ; 150$, VI, "a" e "c", $\S \S^{\circ} 2^{\circ}, 3^{\circ}$ e $4^{\circ}$; e 156 , $2^{\circ}$, I; (ii) capital

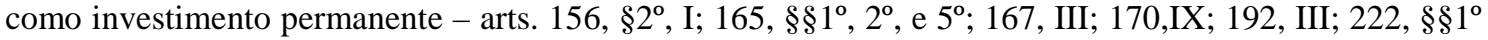
e $2^{\circ}$; (iii) faturamento enquanto conjunto de entradas por vendas ou serviços sem apurar ganhos -art. 195, I; (iv) lucros como resultado positivo de atividade empresarial sem se referir à capacidade contributiva art. $7^{\circ}, \mathrm{XI} ; 172 ; 173,4^{\circ}$; e 195, I. Cf. H. Ávila, Conceito de renda e compensação de prejuízos fiscais, p.33.

${ }^{24}$ Cf. L.E. Schoueri, Direito tributário, pp. 249-250.
} 
dos demais. Assim, algumas de suas características poderão restar desprezadas. Por apresentar limites expressos, o conceito não permite evolução, aliando-se à estática. ${ }^{25}$

Em giro diverso, o tipo não busca definir, mas tão-só descrever o maior número de elementos característicos possível. Por ser essencialmente fluido, sem contornos demarcados, o tipo é dinâmico, permitindo evolução. Não raras vezes, algumas características típicas podem predominar sobre outras, levando ao desaparecimento das preteridas e ao surgimento de novas características, que, por sua vez, poderão suplantar as primeiras. $^{26}$

A distinção entre conceitos e tipos tem relevância no tema da repartição de competências tributárias pela Constituição Federal. Os impostos distribuídos, pelos artigos 153, 155 e 156 da CF, aos entes políticos, não apresentam limites rígidos, mas, ao contrário, expressões fluidas capazes de gerar conflitos de competência. Tanto assim é que o constituinte remeteu à lei complementar a tarefa de dispor sobre conflitos de competência, em matéria tributária, entre a União, os Estados, o Distrito Federal e os Municípios (art. 146, I, CF). Não haveria sentido na previsão constitucional sob análise se os impostos distribuídos tratassem de conceitos. Estes, por serem rígidos, dispensariam o uso de lei complementar. O conflito resulta, justamente, da fluidez dos tipos. $^{27}$

Portanto, a aproximação da realidade sobre rendas e proventos de qualquer natureza foi levada a efeito pelo constituinte não por um conceito jurídico, mas por aproximação tipológica. A atuação do legislador ordinário, por sua vez, deveria moldarse a rígidos limites, de modo que a realidade tipicamente expressa pelo constituinte fosse expressa por conceitos. Daí, com Schoueri, concluir-se que a mesma realidade econômica (renda e proventos de qualquer natureza) observada pelo constituinte por meio de tipos, foi por este imposta ao legislador complementar, para ser expressa por conceitos. $^{28}$

\footnotetext{
${ }^{25}$ Cf. L.E. Schoueri, Direito tributário, p. 251.

${ }^{26}$ Cf. L.E. Schoueri, Direito tributário, p. 251.

${ }^{27}$ Cf. L.E. Schoueri, Direito tributário, pp. 250, 254-255. O autor, baseado na obra de Hannfried Walter e Klaus Vogel (Kommentar zum Bonner Grundgesetz (Bonner Kommentar), $2^{\mathrm{a}}$ revisão do comentário ao art. 105 da Lei Fundamental), na de Vogel (Zur Konkurrenz zwischen Bundes- und Landessteuerrecht nach dem Grundgesetz - Über das 'Anzapfen” von “Steuerquellen'. In Steuer und Wirtschaft, 48 (1), 1971), assim como na de Heinrich Wilhelm Kruse, Lehrbuch des Teuerrechts, v.1, parte geral. Munique: Beck, 1991), sustenta que a repartição de competências é mera opção do constituinte, que não estaria vinculado a questões de ordem lógica. Assim, impostos discriminados no texto constitucional não se amoldam a conceitos, mas a tipos. Por isso o constituinte não define as diversas circunstâncias dos impostos, mas apenas as descreve.

${ }^{28}$ Cf. L.E. Schoueri, Direito tributário, p. 254. O autor
} 
Em sua tarefa de definir tributos e sua espécies, bem como fatos geradores, bases de cálculo e contribuintes em relação aos impostos discriminados na $\mathrm{CF}$, o legislador complementar conceitua renda e proventos de qualquer natureza no artigo 43 do CTN. Neste ponto, cabe retomar as duas teorias econômicas da renda - teorias da fonte ou renda-produto e do acréscimo patrimonial ou renda-acréscimo - para observar que a solução adotada pelo ordenamento brasileiro não foi a de optar por apenas uma das consagradas teorias, mas por ambas. ${ }^{29}$

Se a renda-produto é deveras restrita, não contemplando ganhos eventuais (prêmios de loteria, remuneração única por uma obra etc.) em vista de sua exigência de periodicidade da produção e nem tampouco valorizações da própria fonte permanente (ganhos de capital), bem agiu o constituinte ao positivar um tipo amplo de renda, em harmonia com o princípio da capacidade contributiva, ao prescrever "e proventos de qualquer natureza”, evitando que diversas manifestações de riqueza ficassem excluídas da imposição.

Ao conceituar o que já se encontrava tipificado na Carta Magna, o CTN evidenciou a escolha que lhe competia fazer dentro do arquétipo constitucional da renda, definindo proventos de qualquer natureza como outros acréscimos patrimoniais que não oriundos da teoria da fonte (inc.I), consagrando, destarte, a teoria da rendaacréscimo, ainda que de forma restrita, como se verá a seguir. ${ }^{30}$

\section{IV.1.3. O fato gerador do imposto de renda no CTN}

Materialmente uma lei complementar, o Código Tributário Nacional, ${ }^{31}$ já definira, na ordem anterior à $\mathrm{CF} / 88$, a expressão renda e proventos de qualquer natureza, em seu artigo 43, não havendo registro de incompatibilidade entre o sentido pretérito e o atual. Revela-se, destarte, a recepção desse dispositivo pela Constituição

\footnotetext{
${ }^{29}$ Ainda que com restrições sobre a teoria da renda-acréscimo por questões de praticabilidade e para evitar a cumulação de competências, especialmente, sobre transferências patrimoniais. Para maiores detalhes sobre transferências patrimoniais, v. R.M. de Oliveira, Fundamentos do imposto de renda, p.200. Pela adoção de ambas as teorias também SCHOUERI, Luís Eduardo. O mito do lucro real na passagem da disponibilidade jurídica para a disponibilidade econômica. In: MOSQUERA, Roberto Quiroga e BROEDEL, Alexsandro (org.). Controvérsias jurídico-contábeis - aproximações e distanciamentos, pp. 246. Sobre falhas em ambas as teorias quanto à elaboração de um conceito jurídico-dogmático convincente, v. K. Tipke e J. Lang, Direito tributário (Steuerrecht), p. 470.

${ }^{30}$ Cf. D. Yamashita, Justiça fiscal e princípio da capacidade contributiva, p. 82.

${ }^{31}$ Lei 5.172, de 25 de outubro de 1966.
} 
vigente, inclusive com o prestígio da tarefa do legislador complementar para definir os tributos nos termos do art. 146, III, "a". 32

$\mathrm{Na}$ terminologia do art. 43 do CTN, o imposto de renda terá, como fato gerador, a aquisição da disponibilidade econômica ou jurídica de:

I - de renda, assim entendido o produto do capital, do trabalho ou da combinação de ambos;

II - de proventos de qualquer natureza, assim entendidos os acréscimos patrimoniais não compreendidos no inciso anterior.

Como se vê, o inciso I positiva a teoria da renda-produto, segundo a qual a renda seria o fruto periódico de uma fonte permanente. $\mathrm{O}$ reconhecimento da renda, contudo, exigiria o desprendimento do fruto com relação à fonte, o que se entende por realização, ${ }^{33}$

Já o inciso II consagra a teoria da renda-acréscimo, que entende renda como o saldo positivo dos acréscimos patrimoniais aferido de forma dinâmica, em cortes temporais. $^{34}$

Neste sentido, perde relevância adentrar à etimologia de proventos para lhe descobrir o sentido, já que o termo consagra uma das espécies de acréscimo patrimonial, qual seja, aquela que não está incluída como renda-produto no inciso I. ${ }^{35}$

Sob este ângulo, com Schoueri, afasta-se a idéia generalista de que a renda sempre seria representada por um ganho, um acréscimo patrimonial, entendimento inclusive manifestado pelo $\mathrm{STF}^{36}$ Com efeito, haveria acréscimos patrimoniais compreendidos no inciso I (renda-produto), mas também haveria frutos que não

\footnotetext{
${ }^{32}$ Cf. R.M. de Oliveira, Fundamentos do imposto de renda, p.175.

33 Cf. L.E. Schoueri, $O$ mito do lucro real na passagem da disponibilidade jurídica para a disponibilidade econômica, p. 243.

${ }^{34}$ A falta de definição legal do termo acréscimo patrimonial leva a observação do patrimônio - conjunto de bens, direitos e obrigações que varia continuamente -, que, por sua própria natureza, apresenta-se como grandeza dinâmica que, para fins de tributação, somente permitiria o alcance de sua variação positiva. Assim, o fato gerador do imposto de renda somente poderá gravar tal variação se considerar determinado intervalo de tempo.

${ }^{35} \mathrm{O}$ significado inicial do termo proventos de qualquer natureza estava restrito a valores pagos aos funcionários públicos quando inativos. O termo teria sido adicionado à renda para compor o nome do imposto ainda na vigência do ordenamento imposto pela Constituição de 1934. Ocorre que o alcance da expressão, sob a égide da atual Carta de 1988 é bem mais amplo, devendo-se considerar todos os acréscimos patrimoniais que não referentes à renda-produto, sob pena de inconstitucionalidade do inciso II do art. 43 do CTN. Cf. R.M. de Oliveira, Fundamentos do imposto de renda, p. 172.

${ }^{36}$ STF, $1^{\text {a }}$ Turma, RE 89.971, Rel. Min. Cunha Peixoto, j. 03/10/78, DJU 20/10/78.
} 
representassem tais acréscimos. Um exemplo seriam os rendimentos enviados a nãoresidentes no exterior. ${ }^{37}$

Pode-se concluir, portanto, que a escolha do legislador complementar para definir renda foi bastante ampla, compreendendo:

(i) renda-produto que não acréscimos, como as remessas de rendimentos aos não-residentes. Neste caso, não haveria o intervalo temporal necessário à aferição da variação positiva do patrimônio;

(ii) acréscimos patrimoniais renda-produto: são produto do capital, do trabalho ou da combinação de ambos; e

(iii) acréscimos patrimoniais proventos: são os outros acréscimos que não se revistam da característica de fruto do capital, do trabalho e nem da combinação de ambos (inciso I), como ganhos únicos ou esporádicos (lump-sum), como prêmio de loteria ou ganhos de capital.

Inobstante a abrangente definição de renda positivada pelo legislador complementar, é vero que "a noção jurídica de renda é conceito mais estreito que o conceito de ganho econômico", nas palavras de Kevin Holmes. ${ }^{38}$ E assim deve, de fato, ser, pois o legislador pode ficar aquém da aproximação constitucional de renda, mas não pode lhe ultrapassar as fronteiras. Interessa, pois, saber se no exercício dessas escolhas, o legislador infraconstitucional - complementar e ordinário - respeitou as balizas constitucionais para tributar ou renunciar a tributação da renda com vistas a tornar o Brasil mais competitivo no cenário internacional.

Em tese, renda imputada e rendimentos não realizados estariam compreendidos no conceito de renda preconizado pela teoria da renda-acréscimo. De acordo com esta visão, meras valorizações imobiliárias, serviços domésticos efetuados pelo casal ou o valor do suposto aluguel que se deixa de pagar por residir em casa própria deveriam integrar a base de cálculo do imposto de renda. ${ }^{39}$

Ocorre que há limites intransponíveis à tributação de valores não realizados. Os princípios da capacidade contributiva e da segurança jurídica, operando em conjunto, vedam a possibilidade de tal pretensão. Os valores ainda não realizados não conferem

\footnotetext{
37 Cf. L.E. Schoueri, O mito do lucro real na passagem da disponibilidade jurídica para a disponibilidade econômica, p. 247.

${ }^{38}$ No original: the legal notion of income is a narrower concept than the concept of economic gain. (tradução livre). Cf. K. Holmes, The concept of income - a multidisciplinary analysis, p. 162.

${ }^{39}$ Cf. D. Yamashita, Justiça fiscal e princípio da capacidade contributiva, p. 83.
} 
liquidez e disponibilidade necessárias para aferir capacidade contributiva, a despeito de conferirem algum indício de riqueza; ${ }^{40}$ bem como não conferem a necessária segurança acerca dos valores que integrarão a base de cálculo do imposto. ${ }^{41}$

Essa idéia é suportada por Ian Roxan, para quem a tributação da renda imputada significa a incidência do imposto sobre valor que não corresponde à verdadeira renda do contribuinte. Daí ser possível questionar se o contribuinte adquiriu a disponibilidade econômica ou jurídica de renda, quando a utilização de um de seus bens, por ele próprio, representa o que Roxan chama de valor de consumo no tempo. ${ }^{42}$ Embora pareça representar uma manifestação de capacidade contributiva, não se vê a disponibilidade dessa renda para o contribuinte com tanta clareza.

A ilação decorrente é no sentido de que a teoria do acréscimo patrimonial não foi plenamente acolhida pelo ordenamento pátrio, pois os princípios constitucionais da capacidade contributiva, da segurança jurídica, da igualdade e da justiça impedem a imposição sobre eventuais acréscimos de patrimônio não realizados. ${ }^{43}$

Após essas considerações e de retorno à definição do CTN, não se pode conceber a tributação de renda que não seja adquirida e esteja disponível ao contribuinte. O fato gerador do imposto de renda é, portanto, a aquisição da disponibilidade econômica ou jurídica de renda ou proventos de qualquer natureza. Não será este o palco adequado para aprofundar a discussão sobre o que vem a ser disponibilidade econômica ou jurídica. Por ora, basta reconhecer que a efetiva percepção da renda em dinheiro ou em outros valores significa disponibilidade econômica; e que o direito incondicional, atual e efetivo de aferir e dispor da renda significa disponibilidade jurídica. ${ }^{44}$

Assim, repudia-se a idéia da incidência do imposto de renda sobre situações em que não haja aumento patrimonial efetivo, incondicional e atual. ${ }^{45} \mathrm{~A}$ renda deve

\footnotetext{
${ }^{40}$ Joachim Lang explica que processos de avaliação são especulativos e a necessária certeza do valor da apreciação do bem só será efetivada com a alienação, ocasião em que o mercado se manifesta. Logo, sem realização não há comprovação do valor material do bem em questão. Cita o exemplo de um terreno cujo valor fora primorosamente investigado, mas de forma totalmente equivocada, o que restou comprovado somente por ocasião de sua venda. Cf.. K. Tipke e J. Lang, Direito tributário (Steuerrecht), p. 215.

${ }^{41}$ Cf. D. Yamashita, Justiça fiscal e princípio da capacidade contributiva, p. 84.

${ }^{42}$ ROXAN, Ian. Imputed income (including deductible costs). In: ESSERS, Peter e RIJKERS. Arie (org.). The notion of income from capital. Amsterdam: IBFD, 2005. p. 249. O caso clássico de utilização da própria residência gera a tributação na Noruega, Luxemburgo, Espanha ( $2^{\mathrm{a}}$ residência), Holanda, Itália e Bélgica. No entanto, ainda assim a prática exige como referência o valor declarado do imóvel e não seu valor especulado no mercado.

${ }^{43}$ Cf. D. Yamashita, Justiça fiscal e princípio da capacidade contributiva, p. 89.

${ }^{44} \mathrm{Cf}$. H. Ávila, Conceito de renda e compensação de prejuízos fiscais, p. 35.

${ }^{45} \mathrm{Com}$ a ressalva da renda-produto que não acréscimos supra.
} 
ingressar, efetivamente, no patrimônio do contribuinte, não se cogitando de incidência sobre mera expectativa de ingresso. Isso não significa ingresso de moeda, mas de um direito incondicional a perceber a renda e dela dispor, como bem poderia fazer o contribuinte ao trocar esse direito no mercado. ${ }^{46}$

Da mesma forma, eventual óbice ou condição ao ingresso da renda no patrimônio do contribuinte importa inexistência de qualquer disponibilidade jurídica, afastando a incidência do imposto. $\mathrm{O}$ ingresso da renda deve ser incondicional.

Deve, por fim, a disponibilidade jurídica ser atual, ou seja, exercida. Do contrário, tributar-se-ia a valorização do imóvel não vendido. Naturalmente que o sujeito passivo poderia vendê-lo, mas não se espera que o faça para arcar com os tributos. $^{47}$

Orientação segura acerca dessas conclusões nos lega Tipke, para quem a capacidade contributiva é parâmetro fundamental para a concreção do princípio da igualdade. ${ }^{48}$ Em nossa Carta, encontra-se expresso, servindo de via obrigatória para observância do legislador na persecução do princípio da justiça. Por decorrência, o princípio da capacidade contributiva: ${ }^{49}$

(i) é uma decorrência do ser e não do dever-ser. Este último cabe em economias planificadas, não em economias de mercado, onde se adequa o primeiro. Logo, o imposto deve alcançar renda existente, não ficções sobre o fato gerador do imposto de renda; ${ }^{50}$

(ii) é princípio econômico que alcança apenas renda efetiva, não se importando com renda aparente; e

\footnotetext{
${ }^{46} \mathrm{Cf}$. H. Ávila, Conceito de renda e compensação de prejuízos fiscais, pp. 35.

${ }^{47}$ Cf. H. Ávila, Conceito de renda e compensação de prejuízos fiscais, pp. 35-36.

48 Afirma Klaus Tipke que o "princípio da capacidade contributiva é mundialmente e em todas as disciplinas da ciência da tributação reconhecido como princípio fundamental da imposição justa." Admite, contudo, desvios da capacidade contributiva ao tratar de normas com finalidade social, desde que justificados, afastando a discricionariedade e o arbítrio. Tal justificação deverá ancorar-se nos seguintes princípios: (i) do Bem Comum: afasta tratamento diferenciado a cidaddãos e grupos que detenham interesses prórpios. Normas de fim social devem atender à utilidade geral; (ii) da necessidade: a desoneração fiscal se baseia na necessidade econômica; ou (iii) do merecimento: recompensa condutas proveitosas à coletividade. Cf. K. Tipke e J. Lang, Direito tributário (Steuerrecht), p.200; 230-232.

${ }^{49}$ Cf. K. Tipke, Sobre a unidade da ordem jurídica tributária, pp.64-65. Sob a lente do Estado Social, o direito tributário deve buscar o equilíbrio social pelas normas de finalidade fiscal como por outras que visem à redistribuição, onde se situam as normas indutoras. Em ambos os casos, o princípio da capacidade contributiva estaria presente, pois que social-estatalmente incrustado. $\mathrm{O}$ dever do Estado estaria no amparo aos mais necessitados tanto pela via da imposição como pelos gastos públicos. V. TIPKE, Klaus et LANG, Joachim. Direito tributário (Steuerrecht), pp.261-262.

${ }^{50}$ O STF já afastou a possibilidade de estabelecer como renda ficções legais no RE 117.887-6, Rel. Min. Carlos Velloso, DJU 24/03/93, Cf. H. Ávila, Conceito de renda e compensação de prejuízos fiscais, p. 37.
} 
(iii) atinge apenas a renda disponível para o pagamento de impostos, devendo a base de cálculo ser reduzida pelos gastos a que estiver compelido o contribuinte para fins privados, bem como não poderá adentrar na esfera do mínimo existencial.

Baseado no imperativo categórico de Kant, Tipke dá valiosa contribuição ao direito tributário, fazendo-o avançar em direção a um princípio geral em que se consagre a ética kantiana: agir somente da forma esperada que seja uma lei para todos. Nesta esteira, independente dos termos positivados pelo legislador, espera-se que os impostos pessoais - dentre os quais, o imposto de renda- sejam extraídos tão-só das rendas disponíveis dos cidadãos e dos lucros das empresas, salvo se se pretender a alienação dos bens e do ativo imobilizado para honrar o imposto. É o que Tipke denomina exação nociva sobre a substância. ${ }^{51}$

Portanto, independente do conteúdo semântico de disponibilidade econômica ou jurídica, fato é que o legislador complementar positivou ambas expressões como hipótese de incidência do imposto de renda. Daí a lição de Schoueri: "seja a disponibilidade apenas econômica, seja ela apenas jurídica, seja, enfim, econômica e jurídica, de qualquer modo haverá tributação." O que não se dará é a tributação sem disponibilidade. $^{52}$

\section{IV.1.4 Sujeição passiva ao imposto de renda}

A sujeição passiva da pessoa jurídica tem suscitado divergentes posições quanto à sua legitimidade. Pensa-se, por um lado, que a pessoa jurídica seria mera abstração legal, não detendo, sob o prisma econômico, personalidade independente, autônoma. Segundo esta visão, não haveria sequer capacidade contributiva para a pessoa jurídica. ${ }^{53}$ Em posição diversa, jungida a conceito civilista, a pessoa jurídica seria ente dotado de personalidade jurídica, cuja capacidade contributiva deve ser aferida para fins de imposto de renda. ${ }^{54}$

\footnotetext{
${ }^{51}$ Cf. K. Tipke, Sobre a unidade da ordem jurídica tributária, p. 63.

52 Cf. L.E. Schoueri, $O$ mito do lucro real na passagem da disponibilidade jurídica para a disponibilidade econômica, p. 247.

${ }^{53}$ Em posição contrária ao imposto de renda sobre a pessoa jurídica, v. BRAUNER, Yariv. Revisitando a (in)sensatez do imposto de renda das pessoas jurídicas. In: COSTA, Alcides Jorge; SCHOUERI, Luís Eduardo e BONILHA, Paulo Celso Bergstrom (coord.), Direito Tributário Atual 21. São Paulo: Dialética, 2007. pp. 61-102.

${ }^{54}$ Em defesa da sujeição passiva da pessoa jurídica ao imposo de renda, v. AVI-YONAH, Reuven S.
} 
Lemgruber apresenta duas visões opostas: a tributação do capitalista seria mais justa que a do trabalhador e do consumidor por causa da maior capacidade contributiva daquele em face destes. Em contrapartida, o desestímulo pela tributação da poupança e do investimento (dos ricos) levaria à redução do padrão de vida da população. ${ }^{55}$

Daí decorrem duas formas de tributação da renda: a global, em que toda a renda deve ser tributada da mesma forma, independente da fonte, conforme o sistema SHS; e a cedular ou per baskets, em que cada cesta tem um tratamento fiscal distinto, mais conforme a teoria da tributação ótima. ${ }^{56}$ Não se despreze que o capital é o mais móvel dos fatores de produção e que, na economia global da pós-modernidade, a concorrência tributária internacional tem ajudado a reduzir a imposição fiscal sobre o capital. ${ }^{57}$

Contudo, embora a pessoa jurídica seja, geralmente, considerada distinta da pessoa de seus sócios, em termos econômicos quem realmente arca com o ônus tributário são as pessoas físicas e não as jurídicas, mera abstração legal. ${ }^{58}$ Ocorre que, na seara internacional, está consagrado o imposto de renda corporativo em vários sistemas econômicos do globo. Além de evitar o planejamento tributário, ao gravar pessoas jurídicas ao invés de vários investidores, o imposto de renda corporativo gera economia e praticidade ao Estado, o que se observa no exemplo de investidores que, não fosse a incidência sobre a empresa, escolheriam o momento mais adequado para distribuir dividendos, diferindo o imposto conforme seus interesses pessoais.

Adiciona-se a isso o viés político mais favorável, já que a imposição sobre a pessoa física é medida mais impopular do que sobre a pessoa jurídica. ${ }^{59}$ Justificativas, portanto, de política fiscal e macroeconômica sustentam o imposto de renda sobre pessoas jurídicas. ${ }^{60}$

Fato é que o ordenamento brasileiro prevê a imposição do imposto de renda não apenas sobre indivíduos, mas também sobre pessoas jurídicas. Para o CTN, contribuinte

Pessoas jurídicas, sociedade e o estado: uma defesa do imposto das pessoas jurídicas. In: COSTA, Alcides Jorge; SCHOUERI, Luís Eduardo e BONILHA, Paulo Celso Bergstrom (coord.), Direito Tributário Atual 21. São Paulo: Dialética, 2007. pp. 12-60.

${ }^{55}$ LEMGRUBER, Andréa. A tributação do capital: o imposto de renda da pessoa jurídica e o imposto sobre operações financeiras. In: BIDERMAN, Ciro e ARVATE, Paulo (orgs.). Economia do setor público no Brasil. Rio de Janeiro: Elsevier. 2004, p.208.

${ }^{56} \mathrm{Cf}$. K. Holmes, The concept of income - a multidisciplinary analysis, p. 21.

${ }^{57}$ Cf. A. Lemgruber, A tributação do capital: o imposto de renda da pessoa jurídica e o imposto sobre operações financeiras, pp. 211-212.

${ }^{58}$ STIGLITZ, Joseph. E. Economics of the public sector. 3.ed. Nova York/Londres:WW Norton. 2000, pp.673.

${ }^{59}$ Cf. A. Lemgruber, A tributação do capital: o imposto de renda da pessoa jurídica e o imposto sobre operações financeiras, pp. 213-215.

${ }^{60}$ Cf. J.E.Stiglitz, Economics of the public sector, p. 670. 
do imposto é o titular da disponibilidade econômica ou jurídica de renda ou proventos de qualquer natureza (art. 45), parecendo ter priorizado o enfoque civilista, que atribui personalidade a empresas, salvo quando transparentes, em que prevalecerá o enfoque econômico e a tributação alcançará os sócios.

Para as análises a seguir, embora se reconheça a utilidade do aprofundamento das discussões sobre sujeição passiva de pessoas jurídicas, toma-se como premissa a tributação da renda das empresas por ser considerada pelo legislador doméstico e pela ampla maioria dos sistemas tributários estrangeiros. ${ }^{61}$

IV.1.5 Bases de cálculo do modelo brasileiro do imposto de renda

No que tange ao imposto de renda no Brasil, as pessoas físicas recebem tratamento distinto das pessoas jurídicas. Mariz de Oliveira explica que lucro tributável é expressão que não se refere à pessoa física - salvo quando agir como empresa individual-, uma vez que a idéia de lucro está intrinsecamente ligada à atividade empresarial. De fato, antes que o emprego de fatores de produção em busca de lucro, a pessoa física oferece à tributação a renda derivada do trabalho, do capital financeiro empregado e da venda de seus próprios bens. Portanto, sua base de cálculo é a renda líquida, ou seja, a adição das rendas e proventos recebidos no período-base, ${ }^{62}$ diminuída das deduções e abatimentos legais. ${ }^{63}$

A tributação da renda da pessoa jurídica pode ocorrer por três diferentes sistemáticas: lucro real, lucro presumido e lucro arbitrado. ${ }^{64} \mathrm{Na}$ primeira delas, a base de cálculo do IRPJ será o lucro tributável, cuja apuração depende dos registros efetuados consoante as legislações comercial e fiscal. A regra geral é a tributação do lucro apurado pela contabilidade (lucro líquido), acrescido/subtraído de adições e exclusões autorizadas pela lei tributária, o que perfaz o lucro real. ${ }^{65}$

\footnotetext{
${ }^{61} \mathrm{Cf}$. A. Lemgruber, A tributação do capital: o imposto de renda da pessoa jurídica e o imposto sobre operações financeiras, p.208.

${ }^{62} \mathrm{O}$ período base para pessoas físicas será de 1 ano. Para pessoas jurídicas poderá ser de 1 mês, 1 trimestre ou 1 ano. Cf. Regulamento do Imposto de Renda (Dec. 3.000/99), art.85 (pessoas físicas) e art. 220, 221 e 222 (pessoas jurídicas).

${ }^{63}$ Cf. R.M. de Oliveira, Fundamentos do imposto de renda, pp.652-653.

${ }^{64}$ BRASIL, CTN, Art. 44. A base de cálculo do imposto é o montante, real, arbitrado ou presumido, da renda ou dos proventos tributáveis.

${ }^{65}$ Cf. R.M. de Oliveira, Fundamentos do imposto de renda, pp.654.
} 
O lucro operacional pode ser compreendido como o resultado das atividades que compõem o objeto econômico explorado pela empresa. Uma vez somado ao lucro nãooperacional irá compor o lucro líquido. ${ }^{66}$

Da mesma forma, despesas operacionais são aquelas não computadas nos custos e relacionadas ao objeto da pessoa jurídica, bem como à manutenção de suas fontes produtoras de rendimentos. ${ }^{67} \mathrm{O}$ conceito de despesas dá a idéia de um gasto sem contrapartida, isto é, sem aquisição de um novo direito ou valorização de um já existente. Já os custos, ao contrário das despesas, representam mutação patrimonial com contrapartida, já que há um acréscimo do ativo.

Outra via de apuração da base de cálculo do imposto de renda dá-se pelo lucro presumido, que atende a imperativos de simplificação administrativa e à redução de custos para pequenas e médias empresas. A apuração pelo lucro presumido põe em contato o princípio da capacidade contributiva e o da praticabilidade.

Lemgruber aponta simplicidade administrativa, eficiência e equidade como argumentos em defesa da tributação pelo lucro presumido. ${ }^{68}$ A simplicidade beneficiaria fisco e contribuinte no tocante aos custos para fiscalização e cumprimento da obrigação tributária; a eficiência resultaria do estímulo a empresas para obterem lucro acima da média ofertada à tributação; e a equidade e justiça social garantiriam redução da evasão fiscal comparativamente ao Lucro Real e, ainda, uma arrecadação mínima.

A aplicação de uma porcentagem fixa sobre a receita bruta do período-base, ${ }^{69}$ conforme a atividade da empresa leva parcela de renda disponível a não ser alcançada

\footnotetext{
${ }^{66}$ Cf. R.M. de Oliveira, Fundamentos do imposto de renda, pp.659. Nas palavras de Rubens Gomes de Sousa, o lucro real seria o lucro operacional acrescido/subtraído dos resultados líquidos das transações eventuais. V. SOUSA, Rubens Gomes de. Imposto de renda: despesas não dedutíveis pelas pessoas jurídicas. Seu tratamento fiscal como lucros distribuídos no que se refere à própria sociedade e a seus sócios ou acionistas. In: SOUSA, R.G. de (coord). Pareceres-1 Imposto de Renda, Edição póstuma. São Paulo:IBET: Resenha Tributária, 1975. pp.71-72.

${ }^{67}$ BRASIL, Regulamento do Imposto de Renda (Dec. 3000/99), art. 299. São operacionais as despesas não computadas nos custos, necessárias à atividade da empresa e à manutenção da respectiva fonte produtora.

$\S 1$ - São necessárias as despesas pagas ou incorridas para a realização das transações ou operações exigidas pela atividade da empresa.

$\S 2$ - As despesas operacionais admitidas são as usuais ou normais no tipo de transações, operações ou atividades da empresa.

§ 3o $\mathrm{O}$ disposto neste artigo aplica-se também às gratificações pagas aos empregados, seja qual for a designação que tiverem.

${ }^{68}$ Cf. A. Lemgruber, A tributação do capital: o imposto de renda da pessoa jurídica e o imposto sobre operações financeiras, pp.225-228.

${ }^{69}$ Lei 9.249, Art. 15. A base de cálculo do imposto, em cada mês, será determinada mediante a aplicação do percentual de oito por cento sobre a receita bruta auferida mensalmente (...).

$\S 1^{\circ}$ Nas seguintes atividades, o percentual de que trata este artigo será de:

I - um inteiro e seis décimos por cento, para a atividade de revenda, para consumo, de combustível derivado de petróleo, álcool etílico carburante e gás natural;
} 
pelo IRPJ, o que conflita com o princípio da capacidade contributiva. Neste mesmo sentido, a previsão legal não se encerra com a mínima arrecadação, mas com aquela sobre a disponibilidade econômica ou jurídica de renda do contribuinte.

A aparente violação da capacidade contributiva não deve ser firmada de plano. O conflito de princípios exige o sopesamento dos valores em questão para que ambos sejam aplicados com a máxima eficácia. Logo, em tese são cabíveis concessões à praticabilidade, bem como pode o legislador ter tido em mente estimular o médio e o pequeno empresário desonerando-o caso ultrapasse a renda média de imposição. Neste caso, nem seria a capacidade contributiva o principal critério para verificação da ordem constitucional.

Uma terceira e última alternativa de tributação da renda da pessoa física dá-se quando o contribuinte descumpre obrigação legal de registro em seus livros mercantis e fiscais, impossibilitando o cálculo do lucro tributável, ocasião em que a tributação dá-se por arbitramento.

\section{IV.2 NOTAS SOBRE O SISTEMA BRASILEIRO DE TRIBUTAÇÃO DA RENDA}

\section{IV.2.1 Visão geral do sistema de tributação da renda}

Muito embora o imposto de renda brasileiro tenha longa existência - já que instituído pelo art. 31 da Lei de Orçamento 4.625/22 e emendado, logo a seguir, pelo art. $3^{\circ}$ da Lei $4.783 / 23$, para determinar a imposição sobre toda a pessoa física ou jurídica residente, em período de apuração anual, a partir de 1924 - suas configurações atuais remontam a meados da década de 90, quando o contexto da pós-modernidade

II - dezesseis por cento:

a) para a atividade de prestação de serviços de transporte, exceto o de carga, para o qual se aplicará o percentual previsto no caput deste artigo; (...)

III - trinta e dois por cento, para as atividades de::

a) prestação de serviços em geral, exceto a de serviços hospitalares e de auxílio diagnóstico e terapia, patologia clínica, imagenologia, anatomia patológica e citopatologia, medicina nuclear e análises e patologias clínicas, desde que a prestadora destes serviços seja organizada sob a forma de sociedade empresária e atenda às normas da Agência Nacional de Vigilância Sanitária - Anvisa;

b) intermediação de negócios;

c) administração, locação ou cessão de bens imóveis, móveis e direitos de qualquer natureza;

d) prestação cumulativa e contínua de serviços de assessoria creditícia, mercadológica, gestão de crédito, seleção de riscos, administração de contas a pagar e a receber, compra de direitos creditórios resultantes de vendas mercantis a prazo ou de prestação de serviços (factoring). 
passou a exigir, mais enfaticamente, a abertura da economia brasileira e o interfluxo de negócios com o exterior.

Nesse contexto de indefinições, em face da queda de barreiras comerciais, tecnológicas, culturais, institucionais e econômicas, os fatores tributários tornam-se crescentemente considerados. Destarte, abre-se um leque de opções ao Estado para definir a forma pela qual pretende tributar investimentos (domésticos e) internacionais. Típicas escolhas recaem sobre o tratamento tributário conferido a dividendos sob o IRPJ e IRPF; prioridade para a eficiência/neutralidade na escolha de um sistema; escolha por manter, reduzir ou eliminar bitributação econômica, assim como por aliviá-la ao nível da empresa ou do acionista; definir sobre alíquotas, base de tributação e uso de incentivos fiscais, além de considerar práticas adotadas pelos demais países: ${ }^{70}$

Ainda que timidamente, o País mostrou-se atento à necessidade de efetuar tais escolhas. Ainda no primeiro lustro dos anos 90, quando do início do processo de modernização, o sistema de tributação da renda registrava grande complexidade. Havia enorme retrospecto inflacionário que exigia correção monetária dos balanços de empresas, além de outras questões que geravam distorções e ineficiências, o que dificultava um estudo coerente sobre os resultados alcançados pela tributação da renda. Para exemplificar, enquanto a base tributável cresceu entre 1990 e 1994, a arrecadação do IR caiu, o que, segundo o físco, se deu pela excessiva concessão de incentivos fiscais, como dedução de gastos não vinculados à atividade produtiva (nãooperacionais), incentivos regionais (SUDAM e SUDENE) e a fundos de investimento, depreciações aceleradas entre outros. ${ }^{71}$

A estabilização da moeda foi fator decisivo para que o País pudesse adotar um sistema eficaz de tributação da renda, não apenas do ponto de vista fiscal, mas igualmente para a consecução de políticas econômicas e sociais previstas na Constituição Federal. Este processo de redesenho do imposto de renda estabeleceu como primordiais objetivos: estabilidade, neutralidade, simplificação e internacionalização. ${ }^{72}$

A estabilidade monetária, com o advento do Real em $1^{\circ}$ de julho de 1994, eliminou boa parte da complexidade do imposto de renda, ao permitir que se extinguisse a correção monetária. Em decorrência, atendendo aos reclames da concorrência

\footnotetext{
${ }^{70} \mathrm{Cf}$. OCDE, Taxing profits in a global economy- domestic and international issues, pp.166; 171-173.

${ }^{71}$ BRASIL. Secretaria da Receita Federal. Tributação da renda no Brasil pós-real. Brasília: Dupligráfica, 2001, pp. 16-18.

${ }^{72}$ Cf. SRF, Tributação da renda no Brasil pós-real, p.20.
} 
tributária internacional e da internacionalização das economias, o Brasil promoveu a redução da alíquota básica do IRPJ de $25 \%$ para $15 \%$, ajustando-se à prática corrente mundial. $^{73}$

A neutralidade foi perseguida, dentre outras medidas, pela introdução dos juros sobre capital próprio e pela redução de benefícios fiscais. A partir de 1996, os juros pagos aos sócios como remuneração do capital próprio tornaram-se dedutíveis para apuração do lucro real das empresas. A medida tinha fim não-discriminatório e indutor, pois igualava o tratamento do aporte de sócios com o do mútuo de terceiros e objetivava capitalizar as empresas fomentando o investimento na produção. Os benefícios fiscais foram reduzidos em frentes variadas. Deduções genéricas foram vedadas e o lucro da exploração de atividades monopolizadas, produzido por empresas públicas e sociedades de economia mista, antes excluídos do lucro líquido, passou a ser considerado. ${ }^{74}$

O objetivo da simplificação do pagamento do imposto passou a ser perseguido, com vistas a reduzir os custos administrativos gerados pela própria complexidade do sistema. Basicamente, medidas de tributação da renda presumida foram adotadas para pequenos e médios empresários (estimativa do SIMPLES e do Lucro Presumido). ${ }^{75}$

O quarto dos principais objetivos da política de tributação da renda brasileira após a estabilização da moeda foi a questão internacional. O Brasil procurou moldar seu sistema de tributação de renda aos imperativos da ordem internacional, pois como pontua Joachim Lang, o legislador nacional não age de forma autônoma, mas sob pressão por modificações sistemáticas na tributação de pessoas jurídicas e bens de capital. ${ }^{76}$ Assim, em síntese, houve a edição de novas normas para alterar o critério de tributação territorial para o universal, adotar o crédito de imposto pago no exterior, regrar sobre preços de transferência, além de definir e listar paraísos fiscais. ${ }^{77}$

O sistema brasileiro de tributação da renda prevê o imposto de renda sobre pessoas físicas e jurídicas, sendo que, sobre as últimas, faz incidir a Contribuição Social sobre o Lucro Líquido.

\footnotetext{
${ }^{73}$ Cf. SRF, Tributação da renda no Brasil pós-real,p.33.

${ }^{74} \mathrm{Cf}$. SRF, Tributação da renda no Brasil pós-real,pp.38 e 61.

${ }^{75}$ Cf. SRF, Tributação da renda no Brasil pós-real,p.65.

${ }^{76}$ Cf. J. Lang, A tributação das empresas no contexto da concorrência internacional, p.23.

77 Anteriormente à Lei 9.430/96, já havia. na legislação brasileira, previsão sobre o tratamento de manipulação de preços para transferir resultados - distribuição disfarçada de lucros, conforme DL 1.598/77, arts. 60 a 62, e DL 2.065/83, arts. 20 e 21. Cf. SRF, Tributação da renda no Brasil pós-real, p.21-22.
} 
No caso das pessoas físicas, o sistema brasileiro discrimina quatro grupos de rendimentos de acordo com sua natureza e não por priorização da capacidade contributiva, a saber: ${ }^{78}$

(i) rendimentos gerais: trabalho, aluguéis, royalties e outros que integram a base de cálculo global, na qual são consideradas as deduções pessoais para a aplicação de uma tabela progressiva com alíquotas de 0\% (mínimo existencial preservado), 7,5\%, $15 \%, 22,5 \%$ e $27,5 \%$ na declaração de ajuste anual;

(ii) ganhos de capital na alienação de bens e direitos, que se sujeitam à tributação definitiva (como cédulas) à alíquota de $15 \%$;

(iii) rendimentos produzidos por aplicação financeira de renda fixa, regrados pela Lei 11.033/04, que instituiu uma tabela regressiva conforme o tempo do investimento: 22,5\%, em aplicações com prazo de até 6 meses; 20\%, acima de 6 até 12 meses; 17,5\%, acima de 12 até 24 meses; e 15\%, acima de 24 meses; e

(iv) rendimentos produzidos por aplicação financeira de renda variável, basicamente, $20 \%$, no caso de operação day trade e $15 \%$, nas operações realizadas nos mercados à vista, a termo, de opções e de futuros

O IRPJ apresenta uma alíquota fixa de 15\%, um adicional de 10\% (para renda anual superior a $\mathrm{R} \$ 240.000,00)$ e a CSLL, uma alíquota de 9\%, de modo que a imposição total atinge 34\%. Os ganhos de capital das empresas são adicionados ao total de sua renda tributável. Os prejuízos poderão ser compensados em períodos futuros, mas limitadamente a 30\% do lucro de cada exercício.

\section{IV.2.2. Tributação de não-residentes}

Em geral, os não-residentes que aufiram rendimentos oriundos de fontes brasileiras, em não atuando por meio de filiais, sucursais ou agentes no Brasil, sujeitamse ao imposto sobre a renda na fonte, de forma definitiva, não havendo valores a compensar e tampouco declaração de ajuste a ser entregue. É o que Heleno Tôrres chama de tratamento isolado, em que os rendimentos são submetidos, separadamente, ao tratamento que lhes for individualmente aplicável, conforme sua natureza de juros, royalties, dividendos, e assim sucessivamente. ${ }^{79}$

\footnotetext{
${ }^{78} \mathrm{Cf}$. D. Yamashita, Justiça fiscal e princípio da capacidade contributiva, pp. 90-91.

${ }^{79}$ Cf. H. T. Tôrres, Pluritributação internacional sobre as rendas de empresas, p. 334.
} 
Essa situação se altera, contudo, caso o não-residente atue no Brasil por meio de um estabelecimento permanente. Nesse caso, será equiparado aos residentes no Brasil, pela força de atração do EP, considerando-se os rendimentos do não-residente de forma global, sujeitando-os todos ao regime de lucro de empresa. ${ }^{80}$

Os rendimentos recebidos por não-residentes, de fontes situadas no Brasil, sujeitam-se à tributação exclusiva na fonte, resumidamente, de acordo com os seguintes tópicos: ${ }^{81}$

(i) operações financeiras: regra geral, aplicam-se as mesmas regras previstas para o residente com relação aos rendimentos decorrentes de aplicação de renda fixa e fundos de investimento; bolsa de valores, mercadorias, futuros e assemelhadas.

(ii) ganhos de capital: sujeitam-se à tributação definitiva à alíquota de $15 \%$;

(iii) rendimentos do trabalho e prestação de serviços: sujeitam-se ao imposto na fonte à alíquota de $25 \%$ (exceto serviços técnicos e de assistência técnica e administrativa);

(iv) royalties e serviços técnicos e de assistência técnica e administrativa: sujeitam-se ao imposto na fonte à $15 \%$. No entanto, se esses valores forem recebidos por residente em paraíso fiscal, a alíquota sobe para $25 \%$;

(v) juros: os juros pagos a não-residentes são tributados na fonte à alíquota de $15 \%$

(vi) outros rendimentos: os demais rendimentos pagos ou creditados a nãoresidentes, inclusive juros sobre capital próprio, sujeitam-se ao imposto na fonte à alíquota de $15 \%$.

\section{IV.3 ANÁLISE DA COERÊNCIA DE ALGUNS INSTITUTOS DA TRIBUTAÇÃO DA RENDA À LUZ DE CRITÉRIOS CONSTITUCIONAIS}

Neste tópico, pretende-se apresentar alguns institutos típicos do imposto de renda que representam opções positivadas pelo legislador infraconstitucional. Cada um desses institutos será analisado em face das balizas impostas pela Constituição, sob o corte axiológico da atração de IED.

\footnotetext{
${ }^{80}$ Cf. H. T. Tôrres, Pluritributação internacional sobre as rendas de empresas, p. 335.

${ }^{81}$ Cf. Lei 9.779/99, arts. $7^{\circ}$ e $8^{\circ}$; RIR (Dec. 3000/99), art. 685; MP 2158-35/01, art. 29; MP 2189-49/01, art. 16 e IN/SRF/208/02, arts. 26 a 45.
} 
Considerando a atração de IED como um fator de estímulo ao desenvolvimento econômico, expresso mandamento constitucional (art. $3^{\circ}$, II), deseja-se saber como o legislador do imposto de renda se amolda ao dever de promover o último pela via do primeiro.

Parte-se, pois, do pressuposto de que o legislador pode atender aos requisitos de competitividade do sistema de tributação da renda não somente por meio de subvenções ao investidor, mas também pela norma jurídica arrecadadora, por meio da qual deve configurar transparência, eficiência, estabilidade e coerência de todos os elementos normativos que integram o sistema em tela.

Desta feita, as seguintes análises contemplarão os institutos sob os ângulos da fiscalidade e da indução. A capacidade contributiva será o principal critério informador das normas impositivas que priorizem a fiscalidade. Para normas tributárias indutoras, critérios justificadores da indução devem coexistir com a preservação máxima da capacidade contributiva, o que exige a aplicação do exame de proporcionalidade. $^{82}$ Abrangendo ambas as formas e em respeito à unidade do ordenamento, será aplicado o teste de coerência, que é uma das acepções da razoabilidade. ${ }^{83}$

Assim, os institutos analisados a seguir serão submetidos a três testes consecutivos:

(i) teste 1- concorrência tributária internacional: exige que a norma impositiva ou norma indutora sirva ao fim de aumentar a competitividade do Brasil;

(ii) teste 2- moldura constitucional da renda: exige que o instituto se conforme aos critérios escolhidos pelo constituinte e pelo legislador complementar para definir renda; e

(iii) teste 3-ordem econômica: exige harmonia com as diretrizes econômicas

IV.3.1 Integração da tributação de pessoas físicas e jurídicas

Um dos fatores especialmente considerados pelo investidor é o risco de dupla tributação econômica que poderá resultar da alocação de seu capital. Diferente da bitributação jurídica, na qual a renda de um mesmo contribuinte sofre a imposição por

\footnotetext{
${ }^{82}$ V. tópico II.2.2.

${ }^{83}$ Cf. H. Ávila, Conceito de renda e compensação de prejuízos fiscais, pp. 30.
} 
duas jurisdições, a dupla tributação econômica ${ }^{84}$ pressupõe que a mesma corrente de rendimentos (lucros de pessoas relacionadas) submeta-se à tributação na empresa e seja novamente alcançada na forma de dividendos recebidos pelos sócios. ${ }^{85}$

As decisões do legislador doméstico para a sistemática do imposto de renda, inter alia, escolha da base e das alíquotas, deduções, métodos de depreciação e ajustes inflacionários, serão alvo de análises detidas pelo investidor externo cauteloso. Para este, importa saber do funcionamento do imposto de renda da pessoa jurídica e de seus efeitos sobre o imposto de renda individual conforme as opções facultadas pela lei quanto ao financiamento corporativo.

Os diferentes efeitos da tributação sobre determinada política de financiamento empresarial deram origem a três correntes distintas, a saber: ${ }^{86}$

(i) visão otimista do imposto de renda corporativo: empresas optariam pelo endividamento por ser o meio mais favorecido de financiamento pelos sistemas tributários.

(ii) visão antiga da tributação do dividendo: baseia-se no sistema clássico para dizer, em síntese, que a bitributação de dividendos obstrui significativamente o investimento corporativo. Em um sistema clássico, ${ }^{87}$ os lucros das corporações são tributados após apuração contábil e os dividendos pagos aos acionistas novamente o são. Haveria, pois, desestímulo ao financiamento pela via do aporte de capital. Ademais, no longo prazo, as empresas poderiam ir à bancarrota pelo excesso de endividamento. Segundo seus adeptos, deveria haver a isenção dos dividendos para que o tratamento dos juros (dedutíveis da base de cálculo do IRPJ) não fosse mais vantajoso.

\footnotetext{
${ }^{84}$ A despeito de a bitributação econômica também ser denominada por bitributação dos dividendos, esta denominação é incompleta, pois o fluxo advindo da empresa pode se bifurcar: parte ser distribuída por meio de dividendos e parte ser reinvestida, o que levará as análises para a tributação de ganhos de capital. 85 A bitributação econômica (também denominada bitributação dos dividendos) tem sido, tradicionalmente, um dos mais controversos temas no âmbito do imposto de renda corporativo. Críticas à bitributação econômica: discrimina contra a forma de organização corporativa; favorece dívida em vez de aporte de capital; discrimina contra novas ações em comparação aos lucros retidos e desencoraja o investimento corporativo pelo aumento do custo do capital corporativo. Cf. OCDE, Taxing profits in a global economy- domestic and international issues, p. 17.

${ }^{86} \mathrm{Cf}$. OCDE, Taxing profits in a global economy- domestic and international issues, pp. $26-28$.

${ }^{87} \mathrm{Em}$ um método clássico, os lucros da empresa são alcançados pelo imposto de renda corporativo e os dividendos dos acionistas, pelo imposto de renda individual, ou seja, não há mitigação da dupla tributação econômica. O mesmo se dá com os lucros não distribuídos, que aumentam o valor das ações. São tributados na esfera da sociedade e novamente quando o acionista obtém ganho de capital pela alienação de ações. Portanto, o sistema clássico põe os lucros distribuídos ou retidos em desvantagem com relação aos juros (dedutíveis), estimulando o financiamento societário por meio da dívida e não pela emissão de ações ou capitalização dos lucros retidos. Cf. SILVA, Natalie Matos. A integração da tributação das pessoas jurídicas e das pessoas físicas: análise dos modelos teóricos e de sua adequação ao princípio da capacidade contributiva. In: COSTA, Alcides Jorge; SCHOUERI, Luís Eduardo; BONILHA, Paulo Celso Bergstrom (coord.), Direito Tributário Atual 23. São Paulo: Dialética, 2009, pp. 386.
} 
(iii) nova visão da tributação do dividendo: sustenta que isenção de dividendos não iguala as opções de endividamento e aporte de capital, mas confere elevados ganhos dissociados da atividade empresarial aos acionistas. ${ }^{88}$ Em resumo, esta visão prioriza a retenção de parte suficiente dos lucros pela empresa - até o ponto de garantir o retorno do investimento-, deixando o remanescente à tributação de dividendos.

Influenciados por essas correntes, os países elegeram seus regimes de tributação sobre financiamento de empresas conforme seus interesses. Assim, os EUA optaram pelo método clássico, embora recentemente tenham introduzido medidas para aliviar seus efeitos. ${ }^{89}$ Outros países optaram por métodos de integração ${ }^{90}$ da tributação do

${ }^{88}$ Aloísio Almeida pontua que os defensores da nova visão esclareceram sua valia para empresas maduras, pois para novatas aplicar-se-ia a antiga visão. Cf. ALMEIDA, Aloísio Flávio F. de. A tributação dos lucros e o retorno ao investimento no Brasil. In: Secretaria do Tesouro Nacional/Coletânea de Monografias. Finanças Públicas, IX Prêmio Tesouro Nacional -2004. Brasília-DF: Editora UNB, 2005. p. 474.

${ }^{89}$ Exemplos da suavização do método clássico estão na tributação máxima de $15 \%$ sobre o acionista individual e de dedução entre $70 \%$ e $100 \%$ pelos dividendos recebidos pelo acionista pessoa jurídica. Cf. AULT, Hugh J.; ARNOLD, Brian J. Comparative income taxation - a structural analysis. 2 ed. New York: Aspen Publishers, 2004, p. 329.

${ }^{90}$ Dentre os métodos para integrar a tributação de pessoas físicas e jurídicas, Natalie Silva destaca:

(i) métodos de integração parcial:

i. 1) métodos que reduzem a dupla tributação na esfera do sócio ou acionista

i.1.a) exclusão dos dividendos recebidos: dividendos recebidos pelos sócios, parcial ou integralmente, não comporão sua base de cálculo para o IRPF. A distribuição de dividendos, portanto, é isenta. Não há individualização do IR e nem respeito à capacidade contributiva, pois todos os lucros são tributados na empresa.

i.1.b) crédito dos dividendos recebidos: foi o mais utilizado nas últimas décadas, mas vem sendo substituído na UUEE (em geral distorce a NIC, pois o crédito não é concedido a NREs, priorizando, destarte, o investidor residente). $\mathrm{O}$ acionista recebe um crédito do imposto para abater seu IRPF igual ao IRPJ sobre os lucros auferidos pela sociedade proporcional aos dividendos por ele recebidos.

i.2) métodos que reduzem a dupla tributação na esfera da empresa

i.2.a) alíquota diferenciada: é o chamado split rate method, por meio do qual as alíquotas dos lucros distribuídos são reduzidas enquanto sobre os lucros retidos permanecem elevadas. Na prática, embora mitiguem a dupla tributação sobre dividendos, não os colocam em igualdade com os demais rendimentos, posto que continuam a sofrer maior imposição. A tributação da empresa não pode ser compensada, ainda que seja reduzida.

i.2.b) dedução de dividendos pagos: pessoa jurídica pode deduzir os dividendos que pagar de sua base de cálculo para IRPJ. Na esfera da sociedade, haveria apenas o imposto sobre lucros retidos. É interessante do ponto de vista da capacidade contributiva, uma vez que só as pessoas físicas serão tributadas e de acordo com todas as outras formas de rendimento.

(ii) métodos de integração total:

ii.1) método das sociedades de pessoas: este é o partnership approach. Em suma, não há IRPJ e os lucros são tributados na pessoa física se distribuídos ou retidos (PJ são meros conduítes). Criticável, pois atribuem às pessoas físicas lucros ainda não disponibilizados.

ii.2) método Carter: método da distribuição de lucros e atribuição de lucros retidos (distribution and allocation) criado no Canadá, por meio do Relatório Carter em 1966. Nunca foi aplicado na prática por ser custoso ao Fisco e pouco prático. Em tese, seria um método de integração total, já que todos os lucros auferidos pela empresa seriam distribuídos ou atribuídos aos sócios, de tal modo que toda a renda originária da pessoa jurídica seria, ao fim, tributada pela alíquota do IRPF. Cf. N. M. Silva. A integração da tributação das pessoas jurídicas e das pessoas físicas: análise dos modelos teóricos e de sua adequação ao princípio da capacidade contributiva. pp. 388-400. 
imposto de renda das pessoas jurídicas e das pessoas físicas, como Alemanha, França e Reino Unido. ${ }^{91}$

$\mathrm{Na}$ verdade, a partir de 1960, houve ampla adoção do método da imputação (crédito dos dividendos recebidos) por diversos países, tendência que se alterou a partir de meados dos anos 90, basicamente por causa da complexidade intrínseca à imputação e da discriminação do investidor estrangeiro. ${ }^{92}$

Ault e Arnold apontam a discriminação sobre os investidores internacionais como uma das principais razões para o abandono do método da imputação. A maioria dos métodos de imputação concedia um crédito de imposto somente a acionistas residentes que investissem em empresas residentes e houvessem pago o imposto de renda corporativo doméstico, não restando, assim, qualquer vantagem ao investidor externo. No âmbito da UUEE, haveria violação ao direito comunitário, especialmente em face das liberdades fundamentais, razão pela qual a imputação cedeu espaço para métodos de alívio da tributação sobre dividendos, mais conformes à neutralidade naquele contexto. ${ }^{93}$

Na escolha de suas políticas tributárias, alguns países podem não ter pretendido eliminar, mas conceder somente alívio à bitributação econômica, tornando as opções de financiamento corporativo mais próximas. Fato é que a maioria dos métodos utilizados, sabidamente método da imputação e das alíquotas diferenciadas, proveram apenas integração parcial, mas não total. Esta última pressuporia a concessão de um crédito integral (full credit) aos sócios, não apenas pelo imposto corporativo sobre os lucros distribuídos, mas também sobre os lucros retidos, fazendo do IRPJ mera antecipação do IRPF. ${ }^{94}$

O Brasil optou por isentar os dividendos por meio do art. 10 da Lei 9.249/95, ao estabelecer que os lucros ou dividendos calculados com base nos resultados apurados a partir do mês de janeiro de 1996, pagos ou creditados pelas pessoas jurídicas tributadas

\footnotetext{
${ }^{91}$ Inicialmente, a Alemanha combinou os métodos de imputação integral e alíquota diferenciada (split rate); a França e o Reino Unido optaram, respectivamente, pelo método da imputação total e por um método de imputação parcial. Cf. J. Ault e B. J. Arnold, Comparative income taxation - a structural analysis, p. 329.

92 O método da imputação exige lidar com questões que lhe são típicas e que não seriam tratadas da mesma maneira pelos diferentes ordenamentos, o que aumentaria a complexidade envolvendo o método. Seria necessário, por exemplo, regrar sobre devoluções quando a imposição sobre o acionista individual fosse menor que o imposto corporativo ou sobre o tratamento da renda que perpassasse diversas empresas antes de chegar ao acionista. Cf. H.J. Ault e B.J. Arnold, Comparative income taxation - a structural analysis, p. 327.

${ }^{93}$ Cf. J. Ault e B. J. Arnold, Comparative income taxation - a structural analysis, p. 425.

${ }^{94} \mathrm{Cf}$. OCDE, Taxing profits in a global economy-domestic and international issues, p. 17.
} 
com base no lucro real, presumido ou arbitrado, não ficarão sujeitos à incidência do imposto de renda na fonte, nem integrarão a base de cálculo do imposto de renda do beneficiário, pessoa física ou jurídica, domiciliado no País ou no exterior. ${ }^{95}$

Com essa medida, o Brasil isenta os dividendos do imposto retido na fonte e do imposto de renda das pessoas físicas, mas não atinge o imposto pago sobre os lucros da empresa, aliviando, mas não eliminando em definitivo os riscos de bitributação sobre lucros, ${ }^{96}$ afinal, a medida não contempla a tributação dos ganhos de capital após o reinvestimento dos lucros não distribuídos.

Cumpre, pois, submeter a norma isentiva ao teste afeto à competitividade brasileira. (teste 1). Assim, cumpre apurar se a isenção dos dividendos prevista na Lei 9.249/95 torna o País mais atrativo ao investimento estrangeiro, o que impõe seja analisada a situação do investidor não-residente que receba dividendos de uma empresa em que detenha participação no Brasil.

Em primeiro plano, considere-se um investidor domiciliado em país com o qual o Brasil não mantenha acordo de bitributação. Neste caso, a isenção dos dividendos seria inócua quanto a reduzir os efeitos da bitributação econômica, pois o fato de o Brasil afastar a imposição sobre os dividendos remetidos não evita a tributação sobre esses rendimentos na residência. Se a medida brasileira inexistisse, o investidor seria tributado no Brasil e, provavelmente, em sua residência, mas o risco de bitributação jurídica poderia ser evitado por reciprocidade. Se assim fosse, os resultados quanto à bitributação econômica seriam os mesmos, já que permaneceria a tributação na PJ e a subsequiente no círculo dos sócios, ainda que limitadas as pretensões de cada jurisdição. O resultado somente seria pior na ausência de reciprocidade, o que levaria a mais duas imposições sobre o fluxo de rendimentos além daquela na PJ, uma pelo Brasil e outra pelo país de residência do investidor.

Supondo-se que o investidor seja residente em jurisdição que mantenha acordo de bitributação com o Brasil. O fato de a fonte isentar os dividendos não afasta a competência da residência sobre esses rendimentos, logo, a norma isentiva seria inócua quanto a reduzir os efeitos da bitributação econômica. Caso o Brasil tributasse a

\footnotetext{
95 “Até o ano-calendário de 1995, estavam isentos do imposto de renda somente os lucros e dividendos efetivamente pagos aos sócios, acionistas ou titular de empresa individual que não ultrapassassem o valor que serviu de base de cálculo do imposto, deduzido o imposto correspondente, ficando sujeito à tributação na fonte e na declaração anual dos sócios os valores a eles efetivamente pagos que excedessem aquele valor." Cf. SRF, Tributação da renda no Brasil pós-real,p.59.

${ }^{96}$ Cf. A.F.F. de Almeida, A tributação dos lucros e o retorno ao investimento no Brasil, p. 476.
} 
remessa de dividendos para o exterior, o mecanismo do crédito anularia a bitributação jurídica, mas, do mesmo modo, remanesceria a bitributação econômica.

Uma vez que os acordos objetivam eliminar a bitributação jurídica, repartindo competências entre fonte e residência, rendimentos oriundos de atividades empresariais (entre tantos, dividendos, juros, royalties) encontram-se submetidos ao seu alcance. $\mathrm{O}$ mesmo não se diga dos lucros da pessoa jurídica, salvo se houver previsão acerca do crédito indireto, como ocorre no acordo Brasil - Portugal. ${ }^{97}$

O crédito indireto, na lição de Gerd Rothmann, ${ }^{98}$ permite a compensação, no Estado de residência do investidor, do imposto de renda da pessoa jurídica pago na fonte. Trata-se de exceção, pois os acordos de bitributação ocupam-se do crédito direto, ou seja, aquele correlacionado ao imposto que gravou a distribuição dos dividendos. Como o Brasil não grava a distribuição de dividendos, o investidor não-residente não receberia qualquer crédito.

Entretanto, o crédito indireto (desde que tenha isenção de dividendo) é mais um instrumento a afastar a bitributação econômica, pois o sócio tem direito ao crédito pelo imposto pago pela pessoa jurídica sobre seus lucros, não sobre os dividendos distribuídos. Argumenta-se, pois, que os lucros da pessoa jurídica apurados contabilmente, sujeitar-se-iam a tributação em dois momentos: o primeiro pelo IRPJ e o segundo sobre a parcela destinada aos sócios, que seriam retidos na fonte.

\footnotetext{
${ }^{97}$ BRASIL, Decreto 4.012/91. Artigo $23^{\circ}$ - Método

1. Quando um residente de um Estado Contratante obtiver rendimentos que, de acordo com o disposto nesta Convenção, possam ser tributados no outro Estado Contratante, o primeiro Estado mencionado deduzirá do imposto sobre os rendimentos desse residente uma importância igual ao imposto sobre o rendimento pago nesse outro Estado.

A importância deduzida não poderá, contudo, exceder a fração do imposto sobre os rendimentos, calculado antes da dedução, correspondente aos rendimentos que podem ser tributados nesse outro Estado.

2. No caso de Portugal, quando uma sociedade residente de Portugal receber dividendos de uma sociedade residente do Brasil sujeita ao imposto federal sobre a renda e não abrangida por qualquer isenção, em que a primeira detenha diretamente uma participação não inferior a $25 \%$ (vinte e cinco por cento), Portugal permitirá a dedução de 95\% (noventa e cinco por cento) desses dividendos incluídos na sua base tributável, desde que a referida participação tenha sido detida durante os dois anos precedentes, ou desde a data da constituição da sociedade brasileira, se tiver ocorrido posteriormente, mas em qualquer dos casos unicamente se a participação tiver sido detida ininterruptamente durante esse período.

3. No caso do Brasil, quando uma sociedade residente do Brasil receber dividendos de uma sociedade residente de Portugal sujeita ao imposto português conforme definido na alínea $b$ ) do $n^{\circ} 1$ do Artigo $2^{\circ}$ desta Convenção e não abrangida por qualquer isenção, a dedução prevista no $\mathrm{n}^{\circ} 1$ acima levará em conta o imposto exigível da sociedade relativo aos rendimentos de que se originaram os dividendos pagos (crédito indireto), observadas as disposições da legislação brasileira.

4. Quando um residente de um Estado Contratante obtiver rendimentos que, de acordo com o disposto nesta Convenção, forem isentos de imposto nesse Estado, esse Estado poderá, contudo, ao calcular o quantitativo do imposto sobre os outros rendimentos desse residente, ter em conta os rendimentos isentos.

${ }_{98}^{\circ}$ INSTITUTO BRASILEIRO DE DIREITO TRIBUTÁRIO. Ata da mesa de debates em 12 mar 2009, pp. 4; 8-9. Disponível em www.ibdt.com.br/material/arquivos/Atas/Integra_12032009.htm. Acesso 28 $\operatorname{dez} 2011$.
} 
Alternativamente, caso não haja distribuição ou, ainda que haja, se restar lucros a reinvestir, este segundo momento dar-se-á quando da alienação das ações na forma de ganhos de capital.

A bitributação econômica, portanto, é fenômeno complexo, que vai além da relação entre o imposto de retenção na fonte e o IRPF pelos dividendos recebidos, uma vez que, anteriormente, já teria havido um gravame por ocasião do imposto sobre os lucros da empresa (IRPJ). Somente o crédito indireto poderia alcançar esta última exação.

Deve-se, pois recorrer aos acordos de bitributação para confirmar a previsão do crédito indireto, que aliviaria a bitributação econômica, pois tanto o imposto sobre os lucros da empresa como sobre dividendos distribuídos seriam compensados, respectivamente, pelos créditos indireto e direto. Nos acordos em que não há previsão do crédito indireto, remanesce o IRPJ e eventual tributação pelo influxo dos dividendos na residência do investidor, a depender da legislação doméstica.

Conclui-se, portanto, que a isenção dos dividendos trazida pela Lei 9.249/95 não produz significativos efeitos quanto ao investidor estrangeiro, a despeito de beneficiar o residente. Para obter maior eficácia na atração de IED, a medida dependeria da concessão de créditos indiretos na residência do investidor. Logo, difícil vislumbrar uma correlação direta entre isenção do dividendo e atração do investidor externo.

Por se tratar de norma tributária indutora, a isenção dos dividendos deve se submeter ao exame de proporcionalidade, para verificar sua conformação à moldura constitucional da renda vigente no País (teste 2). Os requisitos de aplicação do exame estão presentes, pois há medida concreta - outorga de isenção sobre dividendos - para atingir um fim precípuo - reduzir ou eliminar a bitributação econômica, favorecendo o investimento estrangeiro.

Em geral, trata-se de medida adequada, pois a isenção é medida de desoneração ao investidor. Ocorre que a medida, por si só, não tem o condão de proteger o investidor não-residente de eventual imposição em seu domicílio. Logo, não se trata de medida adequada a atrair IED, se vista isoladamente.

A medida satisfará ao teste da necessidade se não for flagrantemente menos adequada que outras alternativas para promoção do mesmo fim. Uma vez levado ao extremo, provavelmente o teste da necessidade não aprovaria qualquer meio, pois sempre haverá, sob determinado ângulo, um meio promotor do fim visado em melhores 
condições do que o utilizado. ${ }^{99}$ Ocorre que, in casu, a norma isentiva já claudica no teste da adequação, não parecendo correto tê-la por necessária.

Quanto à proporcionalidade em sentido estrito, investiga-se se as restrições causadas, pelo art. 10 da Lei 9.249/95, aos direitos fundamentais justificam o fim de reduzir ou eliminar a bitributação econômica com vistas à atração de investimento.

Com efeito, os dividendos passaram, com a norma em questão, a receber tratamento específico, já que se tornaram isentos da retenção na fonte e no recebimento pelo sócio da empresa. Outras rendimentos, por sua vez, como juros e juros sobre o capital próprio seriam dedutíveis da base de cálculo do IRPJ, mas alcançados pela retenção na fonte e, posteriormente, tributados de acordo com a tabela progressiva do IRPF.

Por conseguinte, o tratamento conferido aos dividendos, distinto daquele prescrito para outros rendimentos, parece ferir a capacidade contributiva, beneficiando aqueles que se encontrem nas mais altas faixas de tributação da renda individual. ${ }^{100}$

Em virtude de haver outros métodos que igualmente visem à redução da bitributação econômica e, em último grau, à atração de IED, seria possível que a escolha do legislador recaísse sobre algum menos restritivo. Por exemplo, o método de dedução de dividendos conferiria o mesmo tratamento tributário dos juros e dos juros sobre capital próprio, já que a empresa poderia deduzir, para o cômputo da base de cálculo do IRPJ, os dividendos pagos e a tributação ocorreria somente sobre o acionista.

Por outro lado, a restrição à capacidade contributiva não deve ser vista de forma estanque. Por ser a integração um tema repleto de variáveis, cada Estado formula sua política conforme objetivos variados, que podem incluir neutralidade internacional, simplicidade e preservação satisfatória da arrecadação. ${ }^{101}$

No caso brasileiro, o fisco justificou a adoção da isenção dos dividendos com base na neutralidade, simplificação de controles e alívio à bitributação econômica. ${ }^{102}$ Estes seriam, pois, os critérios justificadores da norma indutora sob análise. Por caber à proporcionalidade o dever de conjugar a aplicação máxima dos critérios da norma indutora e da capacidade contributiva, entende-se que a norma trazida pelo art. 10 da Lei 9.249/95 não satisfaz ao teste da proporcionalidade stricto sensu, uma vez que há,

\footnotetext{
${ }^{99}$ Cf. H.B. Ávila, Teoria dos princípios, p. 173.

${ }^{100}$ Cf. N. M. Silva. A integração da tributação das pessoas jurídicas e das pessoas físicas: análise dos modelos teóricos e de sua adequação ao princípio da capacidade contributiva. p. 389.

${ }^{101}$ Cf. N. M. Silva. A integração da tributação das pessoas jurídicas e das pessoas físicas: análise dos modelos teóricos e de sua adequação ao princípio da capacidade contributiva. p. 400.

${ }^{102}$ Cf. SRF, Tributação da renda no Brasil pós-real,pp. 59-60.
} 
disponíveis ao legislador, outros meios de buscar o mesmo fim com menor restrição à capacidade contributiva. Por via de conseqüência, a norma em tela não está em conformidade com a ordem tributária constitucional.

O último teste (teste 3) diz sobre a adequação da isenção dos dividendos com a ordem econômica. Em nosso ver, não há qualquer violação à ordem interna. Igualmente, sob o aspecto internacional, a norma isentiva não discrimina o investidor residente do não-residente, elidindo eventual intervenção da OMC. Adicionalmente, por se tratar de norma geral que não atribui vantagem concorrencial a nenhum setor ou empresa específica, não há falar em subsídio ou tratamento discriminatório, de modo que a norma não se insubordina à ordem econômica.

\section{IV.3.2 Regras CFC - Controlled Foreign Corporations}

Os EUA foram os precursores da edição de regras $\mathrm{CFC}$, ao promulgarem a Subpart $F$ do Internal Revenue Code, em 1962. ${ }^{103}$ Em 1972, Canadá e Alemanha introduziram legislação similar. Da mesma forma o Japão em 1978, a França em 1980 e o Reino Unido em 1984. ${ }^{104}$ A OCDE recomendou a adoção de regras CFC pela $1^{\text {a }}$ vez, em seu Report on International Tax Avoidance and Evasion, em 1987. No ano seguinte, reiterou a recomendação em seu Report 1998 sobre Concorrência Fiscal Prejudicial. Atualmente, essas regras se difundiram pelo globo tendo sido adotadas por diversos países.

O propósito básico da Regra CFC foi estabelecer uma norma antielisão, pois havia expectativa de ganho tributário aos contribuintes que realizassem operações por meio de uma empresa estrangeira, ao invés de uma nacional. ${ }^{105} \mathrm{Na}$ verdade, se o

\footnotetext{
${ }^{103}$ Código Tributário dos EUA.

104 ARNOLD, Brian J.; DIBOUT, Patrick. Limits on the use of low-tax regimes by multinational businesses: current measures and emerging trends general reports. In: Cahiers de droit fiscal international, vol. LXXXVI b. Hague: International Fiscal Association, 2001, p. 38.

${ }^{105}$ Somente entidades estrangeiras independentes e autônomas, sob o ponto de vista do Estado de residência dos acionistas, poderão se qualificar como CFCs. Logo, regras CFC, cujo efeito é a tributação direta dos acionistas residentes sobre os lucros obtidos e ainda não distribuídos pela entidade no exterior, não podem ser aplicadas a filiais, sucursais ou partnerships (entidades transparentes). As entidades híbridas poderão submeter-se ao regime CFC se vistas como entidades autônomas e independentes pelo Estado de residência dos acionistas, ainda que sejam vistas, pelo seu próprio Estado de residência como uma entidade transparente (pass-through entity). No tocante aos trusts estrangeiros que retenham renda sem distribuí-la em determinado exercício, poderá haver a tributação dos beneficiários residentes - tal qual ocorre com o acionista-, como se o trust houvesse, de fato, distribuído a renda, quando de seu recebimento. Esta regra, por exemplo, é aplicada nos EUA e conhecida como throwback rule. Os
} 
acionista americano operasse no exterior por meio de uma filial, a renda obtida por meio desta última seria tributada nos EUA, diretamente, na pessoa dos sócios. Entretanto, caso a operação se desse por meio de uma entidade autônoma e independente para fins tributários, como é o caso de uma corporation, os EUA não poderiam alcançar os lucros por ela produzidos no exterior, gerando um diferimento da tributação até que houvesse a distribuição de dividendos ou a venda de ações com ganho de capital. ${ }^{106}$

Geralmente alcançados pela tributação universal, os residentes sentem-se estimulados a manter suas rendas em controlled foreign corporations (CFCs), uma vez que poderão diferir o tributo do país de residência até o momento em que recebam dividendos ou alienem suas participações com ganho tributável. Este estímulo poderá ser ainda maior se as CFCs situarem-se em paraísos fiscais. Nesta hipótese, talvez seja possível afastar o tributo da residência e da fonte.

Destarte, por meio das regras $\mathrm{CFC}$, o acionista residente deverá incluir como renda tributável a renda ainda não distribuída, proporcional à sua participação no capital daquela CFC, que, neste caso, é vista como uma entidade transparente ou passthrough entity. ${ }^{107}$

Uma controlled foreign corporation, de acordo com o código norteamericano, ${ }^{108}$ é uma empresa na qual mais de $50 \%$ do poder de voto combinado total (voting control test) ou do valor total das ações (value test) é detido direta ou indiretamente por um ou mais acionistas norte-americanos- chamados US shareholders. Estes, por sua vez, também estão previstos pelo código, configurando-se como qualquer pessoa dos EUA que detenha, direta ou indiretamente, no mínimo $10 \%$ do capital votante de uma empresa estrangeira. ${ }^{109}$

O modelo original, portanto, exigia controle manifestado pelo poder de voto ou pelo valor das ações da empresa no exterior. À medida que os países foram criando suas próprias legislações CFC, o controle sobre a empresa estrangeira foi regrado de diversas

acionistas residentes, por seu turno, podem ser indivíduos ou empresas, havendo países que expandem a regra para incluir trusts e estates.

${ }^{106}$ Cf. B.Bittker; L.Lokken, Fundamentals of international taxation. NY:WG\&L RIA, 2003/2004, p. 69-6. ${ }^{107}$ Cf. R. Doernberg, International Taxation in a Nutshell. St Paul, Minnesota, West Group, 2001, p.295.

108 EUA. IRC, $\$ 957$ (a). No original: For purposes of this subpart, the term "controlled foreign corporation" means any foreign corporation if more than 50 percent of - (1) the total combined voting power of all classes of stock of such corporation entitled to vote, or (2) the total value of the stock of such corporation, is owned (...), or is considered as owned by applying the rules of ownership of section 958(b), by United States shareholders on any day during the taxable year of such foreign corporation.

${ }^{109}$ EUA, IRC, § 951 (b). No original: For purposes of this subpart, the term "United States shareholder" means, with respect to any foreign corporation, a United States person (...) who owns (...), or is considered as owning by applying the rules of ownership of section $958(b), 10$ percent or more of the total combined voting power of all classes of stock entitled to vote of such foreign corporation. 
maneiras. Em consequiência, alguns países presumem que seus residentes controlam uma empresa estrangeira caso detenham substancial participação com direito a voto, ainda que em porcentagem inferior a 50\%. Trata-se de um controle de fato. Como exemplo, para Austrália e Nova Zelândia basta que seus residentes detenham $40 \%$ do capital da estrangeira, sem que se exerça um controle superior a 50\% (controle de direito), para a aplicação das regras CFC. ${ }^{110}$

Em França, o artigo 209- B do Code Général des Impôts previa uma participação de $25 \%$ no capital de empresas estrangeiras desde que sujeitas à regime fiscal privilegiado. Esse patamar caiu para 10\% com a alteração promovida pelo art. 107 da loi de finances em 1993. Como o sistema francês, ao contrário do norte-americano, é baseado na tributação territorial, Castagnède afirma que este artigo, produzindo efeitos de tributar o acionista francês pelos resultados produzidos no exterior sob regime fiscal privilegiado, constitui uma derrogação ao princípio da territorialidade previsto no art. 209-1 do CGI. ${ }^{111}$

Como se vê, a proliferação das regras CFC não se deu de modo uniforme, pois cada jurisdição promoveu alterações ao modelo original dos EUA, a fim de adequá-lo a suas peculiaridades e interesses, no âmbito da soberania tributária de cada Estado. Todavia, requisitos gerais adotados pela maioria dos países para caracterizar CFCs, podem ser assim resumidos: ${ }^{112}$

(i) entidade tributária autônoma e independente sob as vistas do país de residência dos sócios: regras $\mathrm{CFC}$ visam a evitar o diferimento na residência, de modo que para fazerem sentido, essas regras devem considerar a entidade estrangeira, como separada e independente dos sócios residentes;

\footnotetext{
110 Cf. B.Arnold e P. Dibout, Limits on the use of low-tax regimes by multinational businesses: current measures and emerging trends general reports, p.42.

111 As regras fixadas pela Loi de finances em 1993, vigentes em $1^{\circ}$ de janeiro de 2003 , trouxeram a aplicação das regras CFC às empresas que se beneficiem, de modo particular, por tratamento fiscal privilegiado, independente de o Estado ou jurisdição em que se encontram adotarem esse regime de forma geral . Este é o sentido do art. 238 do CGI. Castagnède, no original, afirma que le régime vise lês personnes morales passibles de l'impôt sur les sociétés qui exploitent une entreprise hors de France ou détiennent directment ou indirectment 10\% au moins des actions, parts, droits financiers ou droits de vote dans une societé ou um groupement établi hors de France, ou qui detiennent dans une telle société ou groupement une participation dont le prix de revient est égal ou supérieur à 22.800.000 €, dès lors que l'entité extérieure est soumise à um régime fiscal privilégié au sens de l'article $238 \mathrm{~A} . \mathrm{Cf} . \mathrm{B}$. Castagnède, Précis de fiscalité internationale, Paris, PUF, 2006. pp.114-115 e 119.

${ }^{112}$ Cf. B.Arnold e P. Dibout, Limits on the use of low-tax regimes by multinational businesses: current measures and emerging trends general reports, p.42.
} 
(ii) submissão à influência significativa dos sócios em suas atividades: os sócios devem deter o controle ou, no mínimo, participação substancial, influindo nas deliberações da empresa estrangeira;

(iii) sede em jurisdição de baixa ou nenhuma tributação: atendendo a um critério jurisdicional; e

(iv) rendimentos auferidos contaminados: renda ativa não seria tributada pela residência dos sócios, mas apenas os rendimentos contaminados, ${ }^{113}$ em atenção a um critério transacional, ou seja, que verifique cada transação da empresa estrangeira.

No Brasil, a Lei 9.249/95, além de instituir a tributação universal para pessoas jurídicas, previu a tributação de lucros de coligadas e controladas no exterior, ${ }^{114}$ no período em que por elas auferidos, independente de disponibilização desses lucros ao investidor brasileiro. ${ }^{115}$

Trata-se de medida antielisiva cujo alcance vai além de evitar o diferimento prolongado, razão pela qual seria lícito discutir a natureza desse regime especial de tributação de coligadas e controladas no exterior. A bem da simplificação, tal regime doravante será denominado regra CFC brasileira, ainda que divirja, em essência, do conjunto de regras mais amplamente positivado pelos países no tocante ao tema, assim

\footnotetext{
113 Basicamente, os rendimentos contaminados (tainted income) são rendimentos de investimentos passivos, cuja mobilidade é alta (juros, dividendos, aluguéis, royalties, ganhos de capital; e rendimentos de sociedade-base, em que a CFC é utilizada como uma base para aquisição de lucros em outras jurisdições que derivem da atuação de partes relacionadas. O lucro auferido pelas atividades da CFC em sua própria jurisdição não são incluídos na renda da sociedade-base. Cf. MALHERBE, Jacques. Controlled foreign corporations: revisitadas à luz dos tratados de bitributação e do direito comunitário europeu. In: COSTA, Alcides Jorge; SCHOUERI, Luís Eduardo e BONILHA, Paulo Celso Bergstrom (coord.), Direito Tributário Atual 21. São Paulo: Dialética, 2007. pp. 108-109. No mesmo sentido, R. Doernberg, International Taxation in a Nutshell, p. 295.

${ }^{114}$ Segundo a redação conferida pela Lei $11.941 / 09$ ao art. 243 da Lei 6.404/76, considera-se controlada, a sociedade na qual a controladora, diretamente ou através de outras controladas, é titular de direitos de sócio que lhe assegurem, de modo permanente, preponderância nas deliberações sociais e o poder de eleger a maioria dos administradores $\left(\$ 2^{\circ}\right)$.

Já coligadas, são as sociedades nas quais a investidora tenha influência significativa, o que se dá quando a investidora detém ou exerce o poder de participar nas decisões das políticas financeira ou operacional da investida, sem controlá-la. Presume-se, ainda, influência significativa quando a investidora for titular de $20 \%$ ou mais do capital votante da investida, sem controlá-la $\left(\$ \S 1^{\circ}, 4^{\circ}\right.$ e $\left.5^{\circ}\right)$.

${ }^{115}$ Brasil, Lei $9.249 / 95$, Art. $25, \S 2^{\circ}$. Os lucros auferidos por filiais, sucursais ou controladas, no exterior, de pessoas jurídicas domiciliadas no Brasil serão computados na apuração do lucro real com observância do seguinte: I - as filiais, sucursais e controladas deverão demonstrar a apuração dos lucros que auferirem em cada um de seus exercícios fiscais, segundo as normas da legislação brasileira; II - os lucros a que se refere o inciso I serão adicionados ao lucro líquido da matriz ou controladora, na proporção de sua participação acionária, para apuração do lucro real; $\S 3^{\circ}$ Os lucros auferidos no exterior por coligadas de pessoas jurídicas domiciliadas no Brasil serão computados na apuração do lucro real com observância do seguinte: I - os lucros realizados pela coligada serão adicionados ao lucro líquido, na proporção da participação da pessoa jurídica no capital da coligada; II - os lucros a serem computados na apuração do lucro real são os apurados no balanço ou balanços levantados pela coligada no curso do período-base da pessoa jurídica.(grifo nosso)
} 
como do original norte-americano. A justificativa para tanto está no fato de haver características peculiares em cada legislação CFC, não havendo uniformidade.

O modelo brasileiro somente contemplou a pessoa jurídica investidora, considerando os lucros de filiais, sucursais e de coligadas e controladas na apuração de seu lucro real. Filiais e sucursais são extensões da atuação da investidora brasileira que não possuem independência e nem personalidade jurídica autônoma, de modo que a tributação de seus lucros na matriz não enseja controvérsias e encontra guarida no $\S^{\circ}$ do art. 43 do CTN, dispensando as regras CFC. ${ }^{116}$

Diferente é a situação das coligadas e controladas, enquanto estranhas à investidora brasileira, dotadas de personalidade jurídica própria e capacidade tributária autônoma. ${ }^{117}$ Como já visto, a incidência das regras CFC dá-se, regra geral, sobre entidades autônomas sob a óptica do Estado de residência que estejam submetidas à influência significativa do investidor. A legislação brasileira sobre controladas (art. 243 da Lei 6.404/76) sempre valorizou o poder decisório das controladoras, o que foi, recentemente, estendido de modo similar às coligadas, pois as alterações efetuadas pela Lei 11.941/09 substituíram a regra antiga de participação de 10\% no capital para exigirem influência significativa da investidora.

Esta mudança prescreve a necessidade de influência significativa do investidor, por meio de sua atuação nas decisões acerca das políticas financeira ou operacional da investida, para que lucros obtidos por coligadas no exterior sejam alcançados pelo imposto de renda brasileiro. Afinal, sem que delibere acerca das políticas da investida, torna-se difícil justificar que o investidor brasileiro seja tributado por lucros de um terceiro cujo destino foi decidido malgrado seus interesses.

As regras CFC brasileiras não especificam sobre jurisdição ou transação, considerando todos os lucros de coligadas e controladas no exterior como tributáveis no Brasil, independente de a investida receber tratamento fiscal privilegiado ou auferir renda ativa. Logo, o Brasil ignora o critério transacional e o jurisdicional.

Diferente do modelo dos EUA, em que o acionista residente adiciona renda ainda não distribuída, proporcional à sua participação na empresa estrangeira, como se esta fosse uma entidade transparente, o modelo brasileiro exige que seja apurado o lucro

\footnotetext{
${ }^{116}$ BIANCO, João F. Transparência fiscal internacional. São Paulo: Dialética, 2007, pp.54 e 57. Bianco esclarece que não há previsão legal para aplicação desse modelo a pessoas físicas, sócias de empresas no exterior, que deverão ser tributados, apenas, por ocasião da distribuição dos lucros, conforme art. $2^{\circ}$ da Lei 7.713/88.

${ }^{117}$ Cf. J. F. Bianco, Transparência fiscal internacional, p. 54.
} 
no exterior, de acordo com a legislação comercial local e considerando os custos e despesas locais, ${ }^{118}$ que será computado para apuração do lucro real da investidora brasileira em cada 31 de dezembro, independente de distribuição. ${ }^{119}$

Ora, sem distribuição não há a disponibilidade exigida pelo CTN para configurar o fato gerador do imposto de renda. O fisco federal, atento ao problema, baixou a Instrução Normativa SRF 38/96, para regrar que a tributação sobre lucros de coligadas e controladas no exterior somente ocorreria no momento em que tivessem sido disponibilizados.

Ocorre que a IN-SRF 38/96, mera norma complementar nos termos do art. 100 do CTN, não poderia dispor para além dos limites da Lei 9.249/95, ainda menos se opor a seus dispositivos. Com o advento da Lei 9.532/97, que confirmou a exigência de disponibilização dos lucros para a pessoa jurídica domiciliada no Brasil, a questão estaria resolvida em face da conformação com o ordenamento jurídico pátrio.

Em 2001, entretanto, a Lei Complementar 104 veio dispor que o momento e as condições da disponibilização de receitas e rendimentos oriundos do exterior seriam estipulados pelo legislador ordinário. ${ }^{120}$

Desse mister desincumbiu-se a MP 2158-35/01, em seu artigo 74, ao prescrever que lucros de coligadas/controladas no exterior serão considerados disponibilizados para a controladora ou coligada no Brasil na data do balanço no qual tiverem sido apurados. ${ }^{121}$

A materialidade da incidência foi ignorada pela MP 2158-35, que, ao contrário da Lei 9.532/97, impôs uma espécie de "hipótese de disponibilização compulsória" dos lucros auferidos por controladas e coligadas no exterior, na data do balanço no qual tenham sido apurados". 122

\footnotetext{
${ }^{118}$ Este o teor da IN SRF 213/02, que dispõe em seu art. $6^{\circ}$ As demonstrações financeiras das filiais, sucursais, controladas ou coligadas, no exterior, serão elaboradas segundo as normas da legislação comercial do país de seu domicílio. $\S 1^{\circ}$ Nos casos de inexistência de normas expressas no país de domicílio da filial, sucursal, controlada ou coligada ( ...) deverão ser elaboradas com observância dos princípios contábeis geralmente aceitos, segundo as normas da legislação brasileira. (grifo nosso)

${ }^{119}$ Cf. J. F. Bianco, Transparência fiscal internacional, p. 57.

${ }^{120}$ A LC $104 / 01$ acresceu os $\$ \S 1^{\circ}$ e $2^{\circ}$ ao art. 43 do CTN, transcrevendo-se, a seguir, este último: art. $43, \S 2^{\circ}$. Na hipótese de receita ou de rendimento oriundos do exterior, a lei estabelecerá as condições e o momento em que se dará sua disponibilidade, para fins de incidência do imposto referido neste artigo. (grifo nosso)

${ }^{121}$ BRASIL, MP 2158-35/01. Art. 74. Para fim de determinação da base de cálculo do imposto de renda e da CSLL, nos termos do art. 25 da Lei n ${ }^{\circ}$ 9.249, de 26 de dezembro de 1995, e do art. 21 desta Medida Provisória, os lucros auferidos por controlada ou coligada no exterior serão considerados disponibilizados para a controladora ou coligada no Brasil na data do balanço no qual tiverem sido apurados, na forma do regulamento. (grifo nosso)

${ }^{122}$ Cf. J. F. Bianco, Transparência fiscal internacional, p. 57.
} 
A questão foi submetida ao STF na ADI n 2588, em julgamento iniciado em aos 05/02/2003 e suspenso em 17/08/2011, faltando apenas o voto de um Ministro. ${ }^{123}$ A posição da Corte foi dividida em três entendimentos, a saber:

(i) pela constitucionalidade do art. 74 da MP 2.158-35: Min. Nelson Jobim, Min. Eros Grau, Min. Carlos Ayres Britto e Min. Cezar Peluso. Sucintamente, este entendimento é justificado pelo regime de equivalência patrimonial, que teria produzido um ajuste positivo no patrimônio da investidora brasileira a ser computado no resultado do exercício, conforme o regime de competência.

(ii) pela constitucionalidade do art. 74 da MP 2.158-35 se a investidora for controladora e pela inconstitucionalidade se a investidora for coligada: Min. Ellen Gracie. O entendimento da Ministra foi no sentido de que a somente a controladora detém poder decisório e de eleição, enquanto que a controlada não teria como decidir sobre a política financeira e operacional da investida.

(iii) Pela inconstitucionalidade do art. 74 da MP 2.158-35: Min. Sepúlveda Pertence, Min. Marco Aurélio, Min. Lewandowsky e Min. Celso de Mello. Este entendimento, em resumo, baseou-se na impossibilidade de ser criado um fato gerado por ficção, de modo que não pode o legislador ordinário considerar renda adquirida onde não há disponibilidade.

Destarte, o resultado parcial do julgamento da ADI 2588 está em: (i) pela constitucionalidade do art. 74 da MP 2158-35 quanto a controladas: 5 contra 4; e (ii) pela inconstitucionalidade do dispositivo em comento quanto a coligadas 5 contra 4 . A cláusula de reserva de plenário, que exige maioria absoluta dos membros para a declaração de inconstitucionalidade (art. 97, CF), já permite antever que eventual afastamento do art. 74 da MP 2158-35 somente poderá ocorrer quanto a coligadas no exterior.

As regras CFC brasileiras aplicam-se aos lucros obtidos no exterior pelo investidor residente, não possuindo relação com a criação de um ambiente favorável ao investidor estrangeiro, razão pela qual são indiferentes quanto ao teste da concorrência tributária internacional (teste 1). Todavia, do ponto de vista do investidor residente, regras CFC colocam-no em desvantagem, já que muitos dos seus concorrentes não sofrerão imposição sobre renda ativa. Portanto, se se considerar o fim imediato de atração do IED, o teste 1 resta inaplicável. Contudo, se o fim colimado pela norma for ampliado para competitividade brasileira, decerto que será necessário atrair investidores

\footnotetext{
${ }^{123}$ Min. Joaquim Barbosa ausente, em licença para tratamento de saúde.
} 
mas não perder os que já estejam investindo na jurisdição. Sob este segundo ponto, pois, o teste 1 é aplicável e as regras $\mathrm{CFC}$ devem ser reprovadas, uma vez que não concretizam o fim de aumentar a competitividade do País.

Problema maior está na harmonia entre as regras CFC e a moldura constitucional da renda, já que essas regras, dispostas em diferentes instrumentos normativos, ferem, a nosso ver, diversos princípios constitucionais, a começar pela legalidade e a segurança jurídica. Com efeito, não poderia a MP 2158-35 criar hipótese de fato gerador do imposto de renda onde não há disponibilidade, conforme expressamente disposto no CTN.

Neste sentido já havia decidido o STF, quando da apreciação do Imposto sobre o Lucro Líquido, previsto no art. 35 da Lei 7.713/88. ${ }^{124}$ Naquela ocasião, a Corte decidiu que o auferimento de lucros pela investida não é automaticamente reconhecido como auferimento de renda pelo sócios. ${ }^{125}$ Ao final, o Plenário da Corte entendeu que os lucros de uma pessoa jurídica não poderiam ser tributados como renda dos sócios enquanto não fossem disponibilizados, o que somente se daria com sua efetiva distribuição.

A disponibilidade econômica ou jurídica de renda, como visto no item IV.1.3 supra, exige aumento patrimonial efetivo, incondicional e atual, segundo lição de Humberto Ávila. Assim sendo, não há como a investidora brasileira sujeitar-se ao imposto de renda sem a ocorrência do fato gerador, já que não há nem a efetiva disposição do dinheiro (disponibilidade econômica) e nem o direito incondicional de dispor do dinheiro (disponibilidade jurídica) pela mera apuração dos lucros da coligada/controlada no exterior.

Se ao legislador ordinário for franqueado criar ficções para fazer nascer obrigação tributária, será promovida grande insegurança jurídica. Não pode o legislador criar com tinta a materialidade inocorrida. Aqui, ele pretende impor uma distribuição onde não existe a transferência dos valores, mas mera expectativa de um direito que poderá não ser concretizada.

Sobre este ponto, manifestou-se João Bianco ao sustentar que "fatos geradores de obrigação tributária não podem ser fictos, sob pena de ser ferido o princípio da legalidade e da verdade material (...) a efetiva ocorrência da situação de fato ou de direito prevista em lei, como necessária e suficiente à ocorrência do fato gerador do

\footnotetext{
${ }^{124}$ STF, Tribunal Pleno, RE 172.058-1. Rel. Min, Marco Aurélio, DJU 13/10/95.

${ }^{125} \mathrm{Cf}$. H. Ávila, Conceito de renda e compensação de prejuízos fiscais, p. 36.
} 
tributo, é imprescindível para o surgimento da obrigação tributária. É o que determina o artigo 114 do CTN." 126

A questão da igualdade tem diversos matizes. Fere a igualdade a previsão da Lei 9.249/95 ao tratar desiguais de forma igual. As controladas estão submetidas ao poder decisório da controladora, de modo que esta poderá optar por diferir o imposto ao não repatriar lucros pelo tempo que julgar oportuno. As coligadas, até o advento da Lei 11.941/09, eram sociedades em que uma detinha participação mínima de $10 \%$ do capital da outra, sem exercer o controle sobre esta outra. Ora, nada faz supor que esse requisito enseje comando das deliberações da empresa, tal qual ocorre na relação de controle, mundialmente sujeita a regras CFC. Ainda que a Lei 11.941/09 tenha alterado o critério de configuração das coligadas para influência significativa da investidora, não se pode presumir, de forma absoluta, que tal influência decorra da participação de $20 \%$ no capital da investida e, desta forma, haja comando decisório sobre as decisões sobre a destinação dos lucros dessa investida. Para atender ao princípio da igualdade, essa presunção somente pode ser admitida se passível de afastamento perante prova em sentido contrário.

A igualdade é ainda violada quando o legislador despreza o modo de atuação do empresário brasileiro no exterior, ignorando uma análise transacional que assegure o cômputo dos lucros obtidos por controladas ou coligadas no exterior, para efeitos de apuração do IRPJ, somente de renda passiva. Igualar o investidor brasileiro que atua no exterior por meio de empresa produtora (renda ativa) com aquele cujos lucros da investida são fruto de renda contaminada não parece adequado.

Corolário da igualdade, a capacidade contributiva é atingida pelo $§ 5^{\circ}$ do art. 25 da Lei 9.249/95, ao dispor que os prejuízos e perdas decorrentes das operações de controladas e coligadas no exterior não serão compensados com lucros auferidos no Brasil. Inaceitável a regra. Se o resultado positivo apurado no exterior é considerado para apuração do lucro real da pessoa jurídica investidora, não há justificativa para que o resultado negativo apurado seja desprezado para os mesmos fins.

Do mesmo modo, a capacidade contributiva é desrespeitada pela consideração de disponibilidade prevista no art. 74 da MP 2158-35, conforme tratado acima. Disponibilidade precisa ser efetiva, incondicional e atual. Schoueri já havia sustentado a inconstitucionalidade da idéia de tributar renda ainda não disponível para os sócios, uma vez que somente "haverá disponibilidade quando o contribuinte tiver a possibilidade de

\footnotetext{
${ }^{126}$ Cf. J. F. Bianco, Transparência fiscal internacional, p. 79.
} 
pagar o imposto a partir da ocorrência do fato gerador", pois que a capacidade contributiva implica na possibilidade de pagar o imposto de renda, uma vez que se tenha renda para dela dispor. ${ }^{127}$

Embora, neste trabalho, a proporcionalidade tenha sido utilizada, prioritariamente, como exame aplicável a normas tributárias indutoras, útil será submeter as regras CFC ao exame de proporcionalidade, o que é plenamente viável já que se está diante de uma relação de causalidade entre uma media concreta (regras CFC) e um fim (evitar que pessoas jurídicas brasileiras mantenham seu lucros no exterior sem oferecê-los à tributação no Brasil).

O teste de adequação pode ser satisfeito, já que as regras CFC se prestam ao fim que pretendem atingir. Todavia, essas regras não são aprovadas nos testes de necessidade e proporcionalidade stricto sensu. Com efeito, as regras CFC, por terem sido escolhidas pelo legislador somente poderão ser afastadas se houver outro meio flagrantemente mais adequado para combater o diferimento da tributação dos lucros no exterior. Do mesmo modo, esse meio alternativo precisa ser menos restritivo quanto aos direitos fundamentais dos contribuintes.

Pois bem, a manutenção dos lucros no exterior somente trará vantagem ao investidor brasileiro se tais lucros estiverem sujeitos a regime fiscal privilegiado de baixa ou nenhuma imposição. Ao deslocarem seus lucros para países de tributação normal, pouco ou nenhum imposto restaria a pagar no Brasil, em virtude da concessão do respectivo crédito pela legislação doméstica. ${ }^{128}$

Logo, uma medida restrita apenas a jurisdições que concedam regimes fiscais privilegiados (paraísos fiscais) produziria os mesmos resultados em termos de arrecadação aos cofres brasileiros, com menos restrições a direitos dos investidores. ${ }^{129}$

Logo, as regras CFC seriam superadas por outra legislação específica para paraísos fiscais, mais adequada para a promoção do mesmo fim e menos restritiva aos investidores, que teriam redução da obrigação principal e de custos administrativos desnecessariamente causados.

Da reprovação no exame de proporcionalidade, resulta mais um argumento de inconstitucionalidade das regras CFC brasileiras.

\footnotetext{
127 SCHOUERI, L.E. Direito Tributário Internacional - Acordos de Bitributação. Imposto de Renda: Lucros Auferidos por Controladas e Coligadas no Exterior - Disponibilidade - Efeitos do Artigo 74 da Medida Provisória $n^{\circ}$ 2.158-35 -Parecer, in Alcides Jorge Costa, Luís Eduardo Schoueri (org.), Direito Tributário Atual, vol. 16, 2001, pp. 171 e 182.

${ }^{128}$ Cf. J. F. Bianco, Transparência fiscal internacional, p. 82.

${ }^{129}$ Cf. J. F. Bianco, Transparência fiscal internacional, p. 82.
} 
Quanto aos imperativos da ordem econômica (teste 3), decerto que as regras CFC são ineficientes, pois que não atendem à neutralidade de importação de capital e nem à neutralidade de exportação de capital. Quanto à NIC, põem em desvantagem concorrencial o investidor brasileiro com relação a outros investidores estrangeiros que não se sujeitarão ao imposto doméstico sobre renda ativa. Quanto à NEC, desestimula a empresa brasileira a investir no exterior, pois corre o risco de sofrer bitributação, discriminando-a com relação a outra que somente invista internamente. Isso significa quebra de neutralidade concorrencial e violação da livre concorrência e da livre iniciativa protegidas pela $\mathrm{CF}$.

Não foi em vão que as regras CFC brasileira mereceram os comentários do Professor Jacques Malherbe: “(...) o Brasil (...) adotou uma legislação (CFC) que iria praticamente atingir muito além do que qualquer outro sistema, ao considerar os lucros realizados por uma sociedade controlada ou relacionada no exterior como estando disponíveis para a sociedade controladora ou relacionada no Brasil na data do balanço." 130

\section{IV.3.3 Preços de Transferência}

As regras de preços de transferência ou transfer pricing são, por sua própria natureza, de grande valia na qualidade de contramedida à concorrência nociva uma vez que partem de análises funcionais para expressar o que realmente foi desenvolvido por cada unidade do grupo de empresas vinculadas, podendo levar a ajustes das rendas inicialmente declaradas. A utilização dessas regras visa a evitar que as MNEs aloquem seus lucros, por suas diversas unidades, da forma que mais lhes convenha, o que pode significar redução da renda tributável em determinado Estado.

Valendo-se do princípio arm's length, as regras dos preços de transferência procuram aferir os preços de bens, serviços e intangíveis na operação intragrupo, comparando-os com os que teriam sido praticados no mercado aberto, por empresas independentes, em circunstâncias similares.

\footnotetext{
${ }^{130}$ Cf. J. Malherbe, Controlled foreign corporations: revisitadas à luz dos tratados de bitributação e do direito comunitário europeu, p. 111.
} 
O arm's length é princípio consagrado na ordem internacional, positivado, inclusive, em diversos ordenamentos nacionais e no art. $9^{\circ}$ da Convenção Modelo da OCDE. ${ }^{131}$

Embora não se encontre explícito nas regras brasileiras sobre preços de transferência, positivadas nos artigos 18 a 24 da Lei 9.430/96, entende-se que o arm's length foi acolhido em nosso ordenamento jurídico. Não apenas pelo fato de o Brasil assinar acordos de bitributação conforme o Modelo OCDE, mas pela própria vinculação do arm's length aos princípios da justiça e da igualdade que permeiam toda a ordem jurídica.

Assim é porque o arm's length busca, de acordo com fatos e circunstâncias, aferir o valor realmente praticado na transferência de bens e serviços intragrupo. Ante a impossibilidade desse mister, o arm's length terá por fim chegar a um preço de concorrência ou normal, ${ }^{132}$ assim entendido o preço comparável praticado no mercado aberto em circunstâncias similares.

No âmbito da OCDE, as disposições sobre preços de transferência são aplicáveis a pessoas associadas, ${ }^{133}$ enquanto que nos EUA, a pessoas controladas, nos termos da legislação norte-americana. ${ }^{134} \mathrm{O}$ Brasil optou por um conceito mais amplo, aplicando as regras de preços de transferência sobre pessoas vinculadas, conforme disposto no art. 23 da Lei $9.430 / 96 .{ }^{135}$

${ }^{131}$ OCDE, Art. 9 (1): “(When) conditions are made or imposed between ...two (associated) enterprises in their commercial or financial relations which differ from those which would be made between independent enterprises, then any profits, which would, but for those conditions, have accrued to one of the enterprises, but, by reason of those conditions, have not so accrued, may be included in the profits of that enterprise and taxed accordingly."

${ }^{132}$ Cf. R.L.Torres, Tratado de direito constitucional financeiro e tributário- valores e princípios constitucionais tributários, v. II, p. 365.

${ }^{133}$ Pessoas associadas estão definidas no artigo 9 (1) (a) e (b) da Convenção Modelo da OCDE. No original: Art. 9 (1) Where a) an enterprise of a Contracting State participates directly or indirectly in the management, control or capital of an enterprise of the other Contracting State, or b) the same persons participate directly or indirectly in the management, control or capital of an enterprise of a Contracting State and an enterprise of the other Contracting State.

${ }^{134}$ EUA. Tax Regulations, §1.482-1(i)(5). Controlled taxpayer means any one of two or more taxpayers owned or controlled directly or indirectly by the same interests, and includes the taxpayer that owns or controls the other taxpayers. Uncontrolled taxpayer means any one of two or more taxpayers not owned or controlled directly or indirectly by the same interests.

135 BRASIL, Lei 9.430/96, Art. 23. Para efeito dos arts. 18 a 22, será considerada vinculada à pessoa jurídica domiciliada no Brasil:

I - a matriz desta, quando domiciliada no exterior;

II - a sua filial ou sucursal, domiciliada no exterior;

III - a pessoa física ou jurídica, residente ou domiciliada no exterior, cuja participação societária no seu capital social a caracterize como sua controladora ou coligada, na forma definida nos $\S \S 1^{\circ}$ e $2^{\circ}$ do art. 243 da Lei $n^{\circ}$ 6.404, de 15 de dezembro de 1976;

IV - a pessoa jurídica domiciliada no exterior que seja caracterizada como sua controlada ou coligada, na forma definida nos $\S \S 1^{\circ}$ e $2^{\circ}$ do art. 243 da Lei $n^{\circ} 6.404$, de 15 de dezembro de 1976; 
Ao dilargar o conceito de pessoas vinculadas para a aplicação das regras de preços de transferência, o legislador pátrio abrangeu situações em que não haveria qualquer relação de participação no capital entre a empresa residente no Brasil e no exterior. Exemplo seria a mera conexão comercial sem qualquer liame administrativo ou societário, como em consórcio firmado para um empreendimento específico ou em atuação sob a forma de agente exclusivo para a outra parte.

Disso resulta eventual conflito com acordos de bitributação, que não consentiriam no ajuste de preços em operações empreendidas por pessoas que não são associadas, mas que, sob a legislação brasileira, seriam vinculadas. ${ }^{136}$ Nesta hipótese deverá prevalecer o acordo de bitributação, como já se pronunciou o STF no RE 80.004, de conformidade com o art. 98 do CTN. ${ }^{137}$

Os métodos brasileiros para aferição de um preço-parâmetro são semelhantes aos métodos tradicionais recomendados pela OCDE. A norma pátria segrega os métodos de acordo com operações de importação, para as quais haverá um limite máximo às deduções; e de exportação, em que as receitas serão consideradas a partir de um limite mínimo.

V- a pessoa jurídica domiciliada no exterior, quando esta e a empresa domiciliada no Brasil estiverem sob controle societário ou administrativo comum ou quando pelo menos dez por cento do capital social de cada uma pertencer a uma mesma pessoa física ou jurídica;

VI - a pessoa física ou jurídica, residente ou domiciliada no exterior, que, em conjunto com a pessoa jurídica domiciliada no Brasil, tiver participação societária no capital social de uma terceira pessoa jurídica, cuja soma as caracterizem como controladoras ou coligadas desta, na forma definida nos $\S \S 1^{\circ} \mathrm{e}$ $2^{\circ}$ do art. 243 da Lei $n^{\circ} 6.404$, de 15 de dezembro de 1976;

VII - a pessoa física ou jurídica, residente ou domiciliada no exterior, que seja sua associada, na forma de consórcio ou condomínio, conforme definido na legislação brasileira, em qualquer empreendimento;

VIII - a pessoa física residente no exterior que for parente ou afim até o terceiro grau, cônjuge ou companheiro de qualquer de seus diretores ou de seu sócio ou acionista controlador em participação direta ou indireta;

IX - a pessoa física ou jurídica, residente ou domiciliada no exterior, que goze de exclusividade, como seu agente, distribuidor ou concessionário, para a compra e venda de bens, serviços ou direitos;

$\mathrm{X}$ - a pessoa física ou jurídica, residente ou domiciliada no exterior, em relação à qual a pessoa jurídica domiciliada no Brasil goze de exclusividade, como agente, distribuidora ou concessionária, para a compra e venda de bens, serviços ou direitos.

${ }^{136}$ SCHOUERI, Luís Eduardo. Preços de transferência no direito tributário brasileiro. 2 ed. rev. e atual. São Paulo: Dialética, 2006. p.52.

${ }^{137}$ Não se trata, na verdade, de revogar a legislação interna, mas de suspender a eficácia da regra brasileira durante o tempo em que viger o acordo internacional conflitante. Cf. R.L.Torres, Tratado de direito constitucional financeiro e tributário- valores e princípios constitucionais tributários, v. II, p. 368. Schoueri explica os votos dos Ministros do STF no RE 80.004, justificando a prevalência dos acordos internacionais em matéria tributária com base na distinção entre tratados normativos e tratados contratuais. Enquanto os primeiros são genéricos e admitem a adesão de terceiros Estados, os últimos são negociados como se contratos fossem. Justamente pelo respeito ao que foi contratado é que são inalteráveis pela legislação tributária interna. Cf. L.E.Schoueri, Preços de transferência no direito tributário brasileiro, pp. 275-278. 
Os custos, despesas e encargos relativos a bens, serviços e direitos, constantes dos documentos de importação ou de aquisição, nas operações efetuadas com pessoa vinculada, somente serão dedutíveis na determinação do lucro real até o valor que não exceda ao preço determinado por um dos seguintes métodos:

(i) Preços Independentes Comparados (PIC): média aritmética dos preços de bens, serviços ou direitos, idênticos ou similares, apurados no mercado brasileiro ou de outros países, em operações de compra e venda, em condições de pagamento semelhantes; ${ }^{138}$

(ii) Preço de Revenda menos Lucro (PRL): média aritmética dos preços de revenda dos bens, serviços ou direitos diminuídos dos descontos incondicionais, tributos incidentes sobre as vendas, comissões e corretagens pagas, e da margem de lucro pré-determinada $d e:$

(ii.a) $60 \%$ sobre o preço da revenda (após as subtrações acima) deduzido do valor agregado no País, na hipótese de bens importados aplicados à produção; ou

(ii.b) $20 \%$ sobre o preço de revenda, nas demais hipóteses; ${ }^{139}$

(iii) Custo de Produção mais Lucro (CPL): custo médio de produção de idênticos ou similares bens, serviços ou direitos, no país onde foram originariamente produzidos, adicionado dos tributos relacionados à exportação e de uma margem de lucro de $20 \%$ sobre o custo apurado. ${ }^{140}$

Somente haverá ajuste de preços nas exportações para pessoas vinculadas se o preço médio de venda de bens, serviços ou direitos for inferior a $90 \%$ do preço médio praticado na venda dos mesmos bens, serviços ou direitos, no mercado brasileiro,

\footnotetext{
${ }^{138}$ Brasil. Lei 9.430/96, art. 18, I.

${ }^{139}$ Brasil. Lei 9.430/96, art. 18, II.

${ }^{140}$ Brasil. Lei 9.430/96, art. 18, III.
} 
durante o mesmo período, sob condições semelhantes de pagamento. ${ }^{141}$ Neste caso, o preço-parâmetro será calculado consoante um dos métodos a seguir: ${ }^{142}$

(i) Preço de Venda nas Exportações (PVEx): média aritmética dos preços de venda na exportação de idênticos ou similares bens, serviços ou direitos; ${ }^{143}$

(ii) Preço de Venda por Atacado no País de Destino, Diminuído do Lucro (PVA) e Preço de Venda a Varejo no País de Destino, Diminuído do Lucro (PVV): baseados na média aritmética dos preços de venda de idênticos ou similares bens, no mercado atacadista ou varejista do país de destino, respectivamente, diminuídos dos tributos cobrados pelo referido país sobre tais preços e de uma margem de lucro de $15 \%$ sobre o preço do atacado (PVA) ou de 30\% sobre o preço do varejo (PVV); ${ }^{144}$

(iii) Custo de Aquisição ou de Produção mais Tributos e Lucro (CAP): média aritmética dos custos de aquisição ou produção de bens, serviços ou direito exportados acrescidos dos tributos nacionais e de margem de lucro de $20 \%$ sobre a soma dos custos e tributos. ${ }^{145}$

Os métodos brasileiros podem ser agrupados em duas espécies:

(i) comparativos: são o PIC e PVEx que se assemelham ao CUP - Comparable Uncontrolled Method, recomendado método da OCDE sempre que houver disponibilidade de dados para aferir os preços, já que prioriza a comparabilidade; e

(ii) presuntivos-comparativos: todos os demais métodos previstos na legislação brasileira. Esses métodos trabalham com margens de lucros predeterminadas. Como a adoção do arm's length implica na busca do preço real de mercado, inadmissível seria a fixação de margens sem que se pudesse afastá-las. É o que se dá em circunstâncias

\footnotetext{
${ }^{141}$ Os custos e preços médios, referidos nos artigos 18 e 19, devem ser calculados com base em relatórios oficiais publicados pelo governo do país comprador ou vendedor; ou em pesquisas de caráter técnico realizadas por instituições de renome. Todas essas publicações e pesquisas devem resultar da aplicação dos métodos internacionalmente adotados para se aferir preços de transferência. O preço de venda utilizado como parâmetro será líquido. Nas operações internas, descontos incondicionais e tributos (ICMS, ISS, PIS/PASEP e COFINS) deverão ser excluídos. Já nas exportações, o preço final será desconsiderado dos encargos de seguros e frete suportados pelo exportador.

${ }^{142}$ Todos os métodos para aferição do preço de transferência nas exportações fazem uso de uma media aritmética calculada com base no período de apuração da base de cálculo do imposto de renda da empresa brasileira.

${ }^{143}$ Brasil. Lei $9.430 / 96$, art. $19, \S 3^{\circ}$, I.

${ }^{144}$ Brasil. Lei $9.430 / 96$, art. $19, \S 3^{\circ}$, II e III.

${ }^{145}$ Brasil. Lei 9.430/96, art. 19, $\$ 3^{\circ}$, IV.
} 
especiais, quando o Ministro da Fazenda poderá alterar os referidos percentuais. Tais circunstâncias devem ser entendidas como aquelas em que o contribuinte comprove ter levado a registro preço correspondente àquele obtido no mercado aberto, em operação similar praticada por pessoas independentes. ${ }^{146}$

O artigo 22 da Lei 9.430/96 trata dos juros e impõe regra que distingue os juros previstos em contratos registrados e não registrados no BACEN. Portanto, os juros pagos a pessoas vinculadas em contratos não levados a registro no BACEN somente serão dedutíveis até um teto prefixado, ${ }^{147}$ independente da taxa contratada. Contrario sensu, nos contratos registrados serão admitidos os juros determinados com base na taxa registrada.

Trata-se, pois, de medida arbitrária que não se compatibiliza com o arm's length e nem com o sistema constitucional brasileiro. Schoueri sustenta que "o emprego, pelo legislador, de percentuais adrede fixados já não mais condiz com uma busca de renda efetivamente produzida, sendo, antes, a tentativa de tributar uma renda mínima." 148

Lícito concluir que deve ser tributada a renda auferida pelo contribuinte, não uma renda mínima fixada pelo legislador ordinário, razão pela qual tal dispositivo não pode ser tido por constitucional.

A legislação brasileira consente em que os contribuintes escolham o preçoparâmetro mais benéfico, considerando a hipótese de utilização de mais de um método. Destarte, a maior dedução (importação) ou a menor receita (exportações) será considerada para fins tributários. Essa opção do legislador, que aqui se denomina regra do método mais favorável, beneficia os contribuintes, mas contraria o arm's length, cuja essência exige que o preço de transferência seja aferido com base na melhor estimativa do preço praticado ${ }^{149}$

Regras porto seguro ou safe harbours são dispostas na legislação brasileira, embora não sejam recomendáveis por se afastarem do arm's length. Em geral, atendem a reclames de simplificação e redução de custos de cumprimento das obrigações fiscais.

\footnotetext{
${ }^{146}$ Há correspondência entre os demais métodos brasileiros e os recomendados pela OCDE, conforme a seguinte relação: PRL (importações), PVV e PVA (exportações) assemelham-se ao Resale Price Method - RPM; e CPL (importações) e CAP (exportações) são análogos ao Cost Plus Method -COM. A dessemelhança está nas margens prefixadas pela Lei 9.430/96.

${ }^{147}$ Montante que não exceda ao valor calculado com base na taxa Libor, para depósitos em dólares dos Estados Unidos da América pelo prazo de seis meses, acrescida de três por cento anuais a título de spread, proporcionalizados em função do período a que se referirem os juros.

${ }_{148}$ Cf. L.E.Schoueri, Preços de transferência no direito tributário brasileiro, p. 216.

${ }^{149}$ BRASIL. Lei $9.430 / 96$, art. $18, \S 4^{\circ}$ e art. $19, \S 5^{\circ}$.
} 
Materialmente, definem portos seguros em que os ajustes de preços de transferência jamais atracam. Destacam-se, a seguir, quatro dessas regras:

(i) preço médio das exportações a pessoas vinculadas no exterior maior ou igual a $90 \%$ do preço médio de venda dos mesmos bens, serviços ou direitos, no mercado interno;

(ii) juros previstos em contratos registrados no BACEN;

(iii) margem de tolerância de 5\% para mais ou para menos, entre o preçoparâmetro, calculado por um dos métodos legalmente previstos, e o preço registrado pelo contribuinte em seus documentos de importação ou exportação; ${ }^{150} \mathrm{e}$

(iv) a cláusula de penetração de mercado, que autoriza as exportações brasileiras, para pessoas vinculadas, em preço inferior a $90 \%$ do preço médio praticado no Brasil. ${ }^{151}$

O art. 24 da Lei 9.430/96 deu preferência a um critério territorial (paraíso fiscal) em detrimento do subjetivo (pessoas vinculadas), ${ }^{152}$ aplicando as regras de preços de transferência sempre que houver operações entre residentes no Brasil e qualquer pessoa física ou jurídica, ainda que não vinculada ${ }^{153}$ residente em país que não tribute a renda ou o faça à alíquota máxima inferior a $20 \%$, ou, ainda, que oponha sigilo relativo à composição societária de pessoas jurídicas ou à sua titularidade.

Com as alterações trazidas pelas leis 11.727/08 e 11.941/09, as regras de preços de transferência foram estendidas às operações em regime fiscal privilegiado, nas transações entre residentes no Brasil com qualquer pessoa física ou jurídica, ainda que não vinculada, residente ou domiciliada no exterior.

A tônica das regras de preços de transferência é aferir os lucros efetivamente percebidos por uma empresa residente que mantenha relação de interdependência com outra empresa no exterior ou seja unidade integrante de um grupo MNE. Assim, impor essas regras a empresas absolutamente desvinculadas apenas por uma delas estar situada em jurisdição de baixa (ou nenhuma) tributação é desvirtuar o conceito dos preços de transferência.

Em síntese, as regras brasileiras de preços de transferência não são normas de cunho extrafiscal, ao contrário, foram instituídas com o fim de evitar a evasão de

\footnotetext{
${ }^{150}$ BRASIL. IN SRF 243/02, art. 38. Esta Instrução Normativa traz, ainda, em seus artigos 35 e 36, outros dispositivos safe harbours.

${ }^{151}$ BRASIL. IN SRF 243/02, art. 30.

${ }^{152}$ Cf. L.E.Schoueri, Preços de transferência no direito tributário brasileiro, pp.63-64.

${ }^{153}$ Pessoa vinculada, termo utilizado pela legislação brasileira, corresponde à empresa associada na literatura da OCDE.
} 
receitas. Logo, o critério informador principal para a realização dos testes propostos será a capacidade contributiva cuja relação com o arm's length- princípio reconhecido na ordem internacional como apto a produzir os melhores resultados na aplicação das regras de preços de transferência- é bastante estreita.

As regras trazidas pelos artigos 18 a 24 da Lei 9.430/96 estão aprovadas pelo primeiro teste, pois refletem a adoção de uma legislação sobre preços de transferência, como é corrente há muito tempo nos países desenvolvidos. A própria Convenção Modelo da OCDE faz previsão sobre o ajuste de lucros baseado no arm's length, além de recomendar a adoção de regras desse matiz em seu Report 1988 sobre Concorrência tributária Internacional. Com a adoção dessas regras o Brasil se torna mais transparente ao investidor estrangeiro, que poderá melhor prever a forma de atuação nas diversas sedes do grupo MNE quanto à apropriação de lucros no exterior.

O teste 2 verifica a conformação da regra com a moldura constitucional da renda, pois que somente ela deve ser alcançada pela tributação. Assim, reconhece-se a adoção do arm's length pelo legislador nacional pela própria essência do princípio e sua vinculação com a igualdade e a justiça. ${ }^{154}$ Embora implícito, o arm's length prevalece quando a legislação de preços de transferência admite a quebra das margens de lucro pré-determinadas pelos métodos presuntivos em circunstância especiais. Ora, tais circunstâncias não podem ser outras que não aquelas comprovadoras de que o contribuinte registrou valores aferidos em correspondência àqueles praticados no mercado aberto, por empresas independentes em condições similares.

Entretanto, há registros de inconstitucionalidade, por desatenção aos princípios da segurança jurídica, igualdade e, em decorrência, justiça, em alguns dispositivos que exaltam o arbítrio do legislador. Um preço arm's length decorre de fatos $\mathrm{e}$ circunstâncias, exigindo análise cautelosa para ser aferido. Em dadas circunstâncias, porém, entendeu o legislador de afastá-lo, como no caso dos juros em contratos não levados a registro no BACEN; na regra do método mais favorável ao contribuinte e nos dispositivos de porto seguro (safe harbour).

Fato é que, em matéria de preços de transferência, o requisito da constitucionalidade exige comparabilidade e busca de receitas e deduções conforme os preços praticados no mercado aberto, não a maior ou a menor conforme mais

\footnotetext{
${ }^{154}$ Ricardo Lobo Torres classifica o arm's length como princípio vinculado à justiça. Cf. R.L.Torres, Tratado de direito constitucional financeiro e tributário- valores e princípios constitucionais tributários, v. II, p. 358.
} 
beneficiem os contribuintes. Ajustes baseados em métodos devem, forçosamente, perseguir a conversão de reais de grupo para reais de mercado evitando arbítrios injustificados, o que se dá pelo preço arm's length. ${ }^{155}$

Também não se amoldam à Constituição as regras sobre paraísos fiscais que prescindem de vinculação. Empresas que não mantêm qualquer mínimo vínculo submeter-se-ão aos ajustes de preços caso uma delas se situe em país ou jurisdição com regime tributário favorecido. Trata-se de presunção absoluta inafastável e regra inadmissível, devendo, para submeter-se ao conceito de renda passível de tributação, permitir a comprovação dos preços reais de mercado levados a registro pelos contribuintes em operações realizadas com não-vinculadas situadas em paraísos fiscais.

O teste 3 não enseja maiores dificuldades, uma vez que as regras de preços de transferência combatem a evasão, evitando o superfaturamento e o subfaturamento, que, em último grau preserva a livre concorrência evitando vantagens competitivas a custo do tributo. Adiciona-se, ainda, que, em último grau, são regras promotoras da redução das desigualdades conforme prescreve a ordem econômica.

\section{IV.3.4 Regras de Subcapitalização}

O financiamento de uma empresa pode ser feito por aporte de capital dos sócios (equity) ou por endividamento através de contratos de mútuo (debt). Poderá ocorrer de a empresa encontrar-se descapitalizada, em contexto de necessidade para o desempenho do objeto social, endividando-se não pela vontade dos sócios, ao que se designa subcapitalização material. Estrema-se dessa, a situação em que os sócios, deliberadamente, por questões de ordem comercial ou tributária, optam pelo endividamento da empresa por mútuos com pessoas vinculadas, o que se denomina subcapitalização nominal. ${ }^{156}$ Esta última será alvo das análises a seguir.

A remuneração do mútuo são os juros; a do aporte, os dividendos. Uma vez que o tratamento tributário sobre essas espécies de rendimentos é distinto, deve-se considerar a tributação sobre o fluxo da renda que é remetida da pessoa jurídica

\footnotetext{
${ }^{155}$ Cf. L.E.Schoueri, Preços de transferência no direito tributário brasileiro, p. 22.

${ }^{156}$ MONTEIRO, Alexandre Luiz Moraes do Rêgo. As regras de subcapitalização adotadas pela Lei 12.249/10 e sua aplicação em situações abrangidas por acordos para evitar a dupla tributação celebrados pelo Brasil. In: COSTA, Alcides Jorge; SCHOUERI, Luís Eduardo e BONILHA, Paulo Celso Bergstrom; ZILVETI, Fernando Aurélio (coord.), Direito Tributário Atual 24. São Paulo: Dialética, 2010. p. 138.
} 
financiada em dois momentos, um no Estado da fonte e outro no Estado de residência dos sócios, a fím de realizar a melhor opção de financiamento no caso concreto. ${ }^{157}$

Enquanto retorno de financiamento pela opção do aporte, os dividendos oferecem riscos à bitributação econômica, que poderá ser aliviada por um dentre os métodos de integração. ${ }^{158}$ Aos sócios, interessa conhecer o tratamento da fonte e o da residência, a fim de avaliar a tributação incidente sobre todo o percurso da renda, desde a geração e distribuição dos lucros até seu recebimento como dividendos.

Opção de retorno pelo empréstimo, os juros pagos são vantajosamente considerados despesas financeiras, dedutíveis, pois, da base de cálculo do imposto de renda da pessoa jurídica. Adicionalmente, há diversos países que incentivam financiamento por dívida ao não tributarem os juros na fonte ou imporem alíquota de retenção inferior a dividendos. ${ }^{159}$ Quando em mãos dos mutuantes, os juros recebidos, na maioria dos países, sujeitam-se à tributação com direito a crédito pela retenção na fonte. ${ }^{160}$

Em geral, como a pessoa jurídica sofrerá menor incidência tributária, opta-se pelo financiamento por meio de endividamento, que, ademais, permitirá o deslocamento dos rendimentos pagos (dedutíveis da base) para outras jurisdições, ${ }^{161}$ que poderão ser escolhidas por razões tributárias ou não.

Retomando, neste ponto, o conceito de subcapitalização nominal, entende-se o porquê de diversos países adotarem regras antielisivas, de cunho protetor às suas bases de tributação, para combater o planejamento tributário que prioriza o empréstimo deliberado sobre o aporte de capital, denominadas regras de subcapitalização ou thin capitalization rules.

\footnotetext{
${ }^{157}$ Caso não haja qualquer alívio à tributação dos sócios ou da pessoa jurídica financiada, ocorrerá a dupla imposição sobre os lucros distribuídos ou bitributação econômica, tema que foi abordado no tópico IV.3.1.

${ }^{158}$ Os mais comuns são a isenção em virtude de participação substancial (participation exemption) e o crédito dos dividendos recebidos.

${ }^{159}$ CASTRO, Leonardo Freitas de Moraes e; FILHO, Sérgio Papini de Mendonça Uchoa. Thin capitalization rules no direito comparado e as regras de subcapitalização brasileiras. In: Filho, C.P.; Tonani, F.; Behrndt M.A.; Ribeiro, R.P; Vasconcellos, R.F. (coord.), Revista de direito tributário internacional. Ano 5, nº 15, São Paulo: Quartier Latin, 2010, p.175.

${ }^{160}$ Cf. L. F de M. Castro e S.P.de M.U. Filho, Thin capitalization rules no direito comparado e as regras de subcapitalização brasileira, p.176.

161 Cf. A.L.M. do R. Monteiro, As regras de subcapitalização adotadas pela Lei $12.249 / 10$ e sua aplicação em situações abrangidas por acordos para evitar a dupla tributação celebrados pelo Brasil, p. 139. O autor exemplifica o caso de uma holding situada em paraíso fiscal que concede empréstimos a empresas produtivas em jurisdições de tributação normal. Com a dedutibilidade dos juros na fonte, houve o deslocamento de renda tributável para o paraíso fiscal que tampouco tributa a renda (zero tax rate).
} 
O combate à prática da subcapitalização pode ocorrer por regras gerais antielisivas constantes do ordenamento jurídico doméstico ou por legislação específica com este fim. Dentre as regras gerais mais encontradas no direito comparado, merecem destaque: ${ }^{162}$

(i) teoria do abuso de direito ou abuso de forma: pela primeira, a subcapitalização nominal seria considerada lesão a direito subjetivo do fisco - abuso de direito do contribuinte; na segunda, seria vista como instrumento jurídico inadequado. Os juros em excesso, resultantes da aplicação de uma dessas teorias sobre a subcapitalização, serão tidos por dividendos.

(ii) teoria da substância sobre a forma: ${ }^{163}$ essa teoria examina o propósito negocial do contribuinte (business purpose test) para optar pelo endividamento da pessoa jurídica com recursos dos sócios. Logo, será efetuado um confronto entre os motivos extratributários que inspiraram o contribuinte e as razões de ordem tributária, devendo os primeiros compensarem as últimas. $\mathrm{O}$ excesso de juros da subcapitalização será requalificado como dividendo.

(iii) princípio arm's length: este é o princípio por excelência das regras de preços de transferência. No quesito juros, haverá comparação com operações de mútuo entre partes independentes, no mercado aberto, para aferir as condições do contrato celebrado entre pessoas vinculadas - pessoa jurídica e sócios no exterior. Alguns países classificam os juros excessivos como distribuição disfarçada de lucros.

Antes de o legislador brasileiro introduzir regras de subcapitalização em nosso ordenamento, tornou-se conhecido o Caso Colgate, ${ }^{164}$ que retrata complexa operação levada a efeito pela Colgate Palmolive Company para aquisição da Kolynos do Brasil.

Sucintamente, a norte-americana AHP promoveu um leilão privado para venda de negócios ligados à saúde bucal, sagrando-se vencedora a Colgate-Palmolive. Parcela do negócio envolvia a marca Kolynos, cujos direitos eram detidos por Laboratório Wyeth-Whitehall, fabricante no Brasil e subsidiária da AHP. Esta exigiu que o pagamento fosse efetuado no exterior ao que acedeu a adquirente, apesar de possuir

\footnotetext{
${ }^{162}$ Cf. L. F de M. Castro e S.P.de M.U. Filho, Thin capitalization rules no direito comparado e as regras de subcapitalização brasileira, p.181.

${ }^{163}$ Doernberg alude ao caso Helvering v. Gregory (2d. Cir. 1934) como origem da doutrina do business purpose, que sempre deverá ser apreciada para elucidar a substância econômica de um caso concreto. Cf. R. Doernberg. Internatoinal taxation in a nutshell, p. 422.

${ }^{164}$ CONSELHO ADMINISTRATIVO DE RECURSOS FISCAIS. Câmara Superior de Recursos Fiscais, $1^{\text {a }} \mathrm{T}$, Acórdão 9101-00287 de 24/08/09. Rel. Adriana Gomes Rêgo. Disponível em www.carf.fazenda.gov.br. Acesso em 30 nov 2011.
} 
filial no Brasil, segregando as operações referentes à Kolynos para evitar concentração a ser apreciada pelo CADE.

A Colgate Palmolive, então, constituiu subsidiária nos EUA (KAC Corporation) no Brasil (K\&S Aquisições) e, para que o fechamento da operação se desse no exterior, no Uruguai (Albala). KAC Corporation detinha 99,99\% do simbólico capital de R \$ 100,00 de $K \& S$ Aquisições. Albala, por seu giro, fora constituída sob o controle de $K \& S$ Aquisições.

Pela parte vendedora, foram constituídas Kolynos do Brasil SA e, no Uruguai, Yonkers que passou a deter o patrimônio da primeira, após transferência realizada por Laboratório Wyeth-Whitehall.

Em 10/01/95, K\&S contratou mútuo com KAC Corporation no valor da operação da Kolynos (US\$ 760 milhões), sendo que, na mesma data, emprestou os recursos a Albala. Ainda na mesma data, Albala adquiriu as ações de Yonkers, passando a deter Kolynos do Brasil SA. Contudo, como Albala pertencia a K\&S Aquisições, esta, na verdade, se tornou a detentora de Kolynos do Brasil $S A .{ }^{165}$ Posteriormente, a $K \& S$ Aquisições alterou a denominação para Kolynos do Brasil Ltda, incorporando a adquirida Kolynos do Brasil SA. No período entre setembro/1996 e janeiro/1997, Colgate-Palmolive Ltda, empresa brasileira e Kolynos do Brasil Ltda efetuam operações que resultaram na incorporação daquela por esta última.

Pelo fato de terem sido realizadas fora do Brasil, as operações viram-se a salvo do imposto de renda sobre ganhos de capital. Ainda que se pretendesse alcançar mais valia obtida no exterior, o fisco brasileiro estaria tolhido por inexistir elemento de conexão à época dos fatos, já que a sistemática vigente no Brasil estava baseada na territorialidade. $^{166}$

O fisco entendeu, no entanto, que a aquisição da Kolynos do Brasil SA foi estruturada com base em contratos de empréstimo, quando deveria ter resultado de aporte de capital para aquisição acionária. Logo, os encargos do mútuo pagos pela subsidiária brasileira à KAC Corporation não poderiam ser tidos por despesas necessárias, restando indedutíveis dos cálculos para apuração do lucro real.

\footnotetext{
${ }^{165}$ Após a aquisição de Yonkers por Albala, em 17/01/1995, houve uma redução do capital social da primeira, recebendo a última, em troca, um investimento direto na Kolynos. Em 30/01/1995, Albala, por meio de dação em pagamento, transferiu as ações que possuía na Kolynos, no valor de US\$ 760 milhões, com o fim de quitar o empréstimo contraído junto à K\&S Aquisições. Cf. CARF, Câmara Superior de Recursos Fiscais, $1^{\text {a }}$ T, Acórdão 9101-00287, p. 3.

${ }^{166}$ A Lei $9.249 / 95$, que introduziu a tributação universal para pessoas jurídicas, passou a produzir efeitos a partir de 01 de janeiro de 1996. V. Tópico I.1.2,
} 
A $1^{\text {a }}$ Câmara do Conselho de Contribuintes, em 10/07/06, por maioria de votos, acolheu o recurso da Colgate. Porém, em sede de recurso apresentado pela Fazenda Nacional, a $1^{\text {a }}$ Turma da Câmara Superior de Recursos Fiscais reverteu o entendimento pelo voto de qualidade. A Corte decidiu pela indedutibilidade dos juros, que foram tidos por despesas não-necessárias em operação de empréstimo entre pessoas vinculadas, já que a mutuante detinha $99,99 \%$ do capital social da mutuária e dispunha de recursos para integralizar o capital.

O caso merece registro, pois as decisões da Corte Administrativa basearam-se em regras de subcapitalização, mesmo sem norma vigente no ordenamento brasileiro. Em seu voto, a Relatora registrou: ${ }^{167}$

“(...) ouso divergir do relator do voto condutor do acórdão recorrido quanto ao entendimento de que, como no Brasil não há regras de subcapitalização, tais juros e variações cambiais deveriam ser tratados como despesas dedutíveis.

(...) entendo que a decisão entre contrair empréstimos ou capitalizar é uma conveniência da empresa. Contudo, afirmar que despesas advindas do empréstimo são necessárias para que a empresa funcione e se mantenha, extrapola os limites da lógica porque se "A" empresta para "A". "A" não precisa deste empréstimo, porque detém os recursos emprestados."

Entendimento contrário foi manifestado por Ricardo Mariz de Oliveira, para quem despesas necessárias são aquelas inerentes às atividades da pessoa jurídica, que dispensam justificativas de ordem administrativa. Tratar-se-ia, pois, de conceito objetivo. No caso Colgate, os recursos foram empregados para aquisição de outra pessoa jurídica, configurando-se o que definiu por "inerência total" às atividades da adquirente. $^{168}$

Pouco após o julgamento do caso Colgate (24/08/2009), o Brasil adotou regras específicas de subcapitalização por meio da MP 472 (15/12/2009), que restou convertida na Lei 12.249 (11/06/2010). As regras domésticas estipularam o regime de dedutibilidade dos juros pagos a pessoas vinculadas residentes no exterior, com base

${ }^{167}$ Cf. CARF, Câmara Superior de Recursos Fiscais, $1^{\text {a }}$ T, Acórdão 9101-00287, pp. 15-16.

${ }^{168}$ INSTITUTO BRASILEIRO DE DIREITO TRIBUTÁRIO. Ata da mesa de debates em 08 de abril de 2010, p.5. Disponível em www.ibdt.com.br/material/arquivos/Atas/Integra_08042010.htm. Acesso em 28 dez 2011. 
numa relação entre dívida e capital (debt/equity ratio) de 2:1. Em suma, o endividamento será dedutível na forma de juros até o dobro da participação das pessoas vinculadas no exterior. Trata-se, pois, de limite objetivo ao planejamento tributário internacional efetuado por grupos MNEs. ${ }^{169}$

Fixou o legislador, assim, uma razão entre o montante do endividamento e a participação de pessoas vinculadas no patrimônio líquido da financiada para que os juros, até certo limite, sejam dedutíveis da base de cálculo do imposto de renda com segurança. Caso não excedam o limite legal, os juros estarão protegidos de eventual requalificação e o conseqüiente tratamento fiscal distinto (safe haven). ${ }^{170}$

Diz a regra brasileira que o valor do endividamento será verificado por ocasião da apropriação dos juros. Assim, como o endividamento compõe o numerador da razão capaz de determinar o limite de dedutibilidade dos juros da subcapitalização, a data da apropriação dos juros torna-se deveras relevante, por sua capacidade de refletir a variação cambial do contrato de mútuo. Na prática, poderá haver uma valorização ou desvalorização abrupta da moeda nacional, para a qual se deve converter o valor do contrato, reduzindo ou aumentando o limite de dedutibilidade. ${ }^{171}$

Esse é um risco inerente à subcapitalização nominal. Caso haja redução dos juros previstos, no início do contrato, como dedutíveis, o grupo econômico deverá contabilizar essas perdas com relação a fatores não-tributários que o levaram a optar pela subcapitalização. Não parece possível caracterizar por arbitrária a conduta do legislador, que franqueou ao contribuinte a opção dos dividendos e, ainda, dos juros sobre capital próprio como alternativas de tratamento tributário distinto.

\footnotetext{
${ }^{169}$ Cf. A.L.M. do R.Monteiro, As regras de subcapitalização adotadas pela Lei 12.249/10 e sua aplicação em situações abrangidas por acordos para evitar a dupla tributação celebrados pelo Brasil, p. 143.

${ }^{170}$ Brasil, Lei 12.249/09, Art. 24. Sem prejuízo do disposto no art. 22 da Lei no 9.430, de 27 de dezembro de 1996, os juros pagos ou creditados por fonte situada no Brasil à pessoa física ou jurídica, vinculada nos termos do art. 23 da Lei $\mathrm{n}^{\circ}$ 9.430, de 27 de dezembro de 1996, residente ou domiciliada no exterior, não constituída em país ou dependência com tributação favorecida ou sob regime fiscal privilegiado, somente serão dedutíveis, para fins de determinação do lucro real e da base de cálculo da Contribuição Social sobre o Lucro Líquido, quando se verifique constituírem despesa necessária à atividade, conforme definido pelo art. 47 da Lei ${ }^{\circ}$ 4.506, de 30 de novembro de 1964, no período de apuração, atendendo aos seguintes requisitos:

I - no caso de endividamento com pessoa jurídica vinculada no exterior que tenha participação societária na pessoa jurídica residente no Brasil, o valor do endividamento com a pessoa vinculada no exterior, verificado por ocasião da apropriação dos juros, não seja superior a 2 (duas) vezes o valor da participação da vinculada no patrimônio líquido da pessoa jurídica residente no Brasil;

II - no caso de endividamento com pessoa jurídica vinculada no exterior que não tenha participação societária na pessoa jurídica residente no Brasil, o valor do endividamento com a pessoa vinculada no exterior, verificado por ocasião da apropriação dos juros, não seja superior a 2 (duas) vezes o valor do patrimônio líquido da pessoa jurídica residente no Brasil.(grifo nosso)

${ }^{171}$ Cf. L. F de M. Castro e S.P.de M.U. Filho, Thin capitalization rules no direito comparado e as regras de subcapitalização brasileira, p.201.
} 
Os juros, para serem dedutíveis, segundo as regras brasileiras, devem se constituir em despesa necessária à atividade. ${ }^{172}$ Destarte, não há requalificação do excesso como dividendos ou distribuição disfarçada, já que a previsão legal é no sentido de que o excedente dos juros será considerado despesa não necessária à atividade da empresa, e não dedutível para fins do Imposto de Renda. ${ }^{173}$

Para o caso de juros pagos a pessoas residentes ou domiciliadas em paraísos fiscais, independente de vinculação, a relação dívida/capital será de 0,3:1. Assim, somente serão dedutíveis os juros se o valor do endividamento com pessoa situada em paraíso fiscal restringir-se ao limite de $30 \%$ do patrimônio líquido da financiada no Brasil e total do somatório dos endividamentos com todas as entidades situadas em paraíso fiscal restringir-se ao limite de $30 \%$ do valor do patrimônio líquido da pessoa jurídica residente no Brasil.

Nesses casos, as regras brasileiras adotaram o conceito de beneficiário efetivo, tal qual desenvolvido nos EUA. Assim, a dedutibilidade de juros pagos a pessoas em paraísos fiscais exige, cumulativamente:

(i) a identificação do efetivo beneficiário da entidade no exterior, destinatário dessas importâncias; ${ }^{174}$

(ii) a comprovação da capacidade operacional da pessoa física ou entidade no exterior de realizar a operação; e

(iii) a comprovação documental do pagamento do preço respectivo e do recebimento dos bens e direitos ou da utilização de serviço.

No que toca à adequação da regras brasileiras sobre subcapitalização (teste 1) à concorrência tributária internacional, deve-se registrar que a adoção dessas regras atende aos reclames de proteção da própria base tributária, em sentido oposto ao da concorrência nociva. Sendo o Brasil um país de alta carga tributária, adequado que legisle contra a elisão e a evasão de receitas. Aliás, confere segurança ao investidor ao definir, claramente, qual seu limite de tolerância à dedutibilidade de juros que serão

\footnotetext{
${ }^{172}$ Conforme definida nos termos do art. $47, \S 1^{\circ}$, da Lei $\mathrm{n}^{\circ} 4.506 / 64$ : São necessárias as despesas pagas ou incorridas para a realização das transações ou operações exigidas pela atividade da empresa (grifo nosso).

${ }^{173}$ Este é o teor do $\S 3^{\circ}$ do art. 24 da Lei 12.249/10, segundo o qual, o valor dos juros relativos ao excesso em relação aos limites fixados (ratio 2:1) será considerado despesa não necessária à atividade da empresa e não dedutível para fins do IR e da CSLL.

${ }^{174}$ Segundo o $\S 1^{\circ}$ do art. 26 da Lei $12.249 / 10$, considerar-se-á como efetivo beneficiário a pessoa física ou jurídica não constituída com o único ou principal objetivo de economia tributária que auferir esses valores por sua própria conta e não como agente administrador fiduciário ou mandatário por conta de terceiro.
} 
destinados aos próprios sócios de uma empresa financiada no Brasil. Na esteira da competitividade internacional, não importa apenas atrair o IED, mas também evitar a fuga de recursos, mantendo o capital na jurisdição. As regras de subcapitalização atendem a este desiderato ao combaterem o deslocamento de renda tributável para jurisdições de tratamento fiscal privilegiado.

No contexto da moldura constitucional da renda (teste 2), nada desabona o instituto perante os critérios escolhidos pelo legislador complementar para definir renda. Do mesmo modo, não há desrespeito a princípios da ordem tributária. Ao contrário, como dito, valoriza o princípio da segurança que deve orientar os contribuintes e, de forma paralela, o da legalidade pela certeza conferida pelas regras de subcapitalização.

Quanto ao princípio arm's length, indicativo de capacidade contributiva em matéria de preços de transferência, ressalta-se seu estreito contato com regras de subcapitalização. A legislação brasileira poderá utilizar o arm's length para aferir se os juros praticados entre partes vinculadas correspondem aos praticados no mercado, ao passo que as regras de subcapitalização poderão efetuar um controle quantitativo sobre o principal dos contratos de mútuo. Na hipótese de um contrato estipular juros superiores aos previstos pela Lei 9.430/96 (taxa LIBOR + 3\% para contratos sem registro no BACEN), o limite de dedutibilidade ficará restrito ao determinado pelas regras de preços de transferência.

Já o teste 3, que verifica a conformação das regras de subcapitalização à ordem econômica, aprova as referidas regras sob o argumento de que, ao combaterem o planejamento internacional, preservam a liberdade concorrencial e estimulam o desenvolvimento pela preservação das receitas e das condições de igualdade no mercado que promovem.

Não se deixe de registrar, todavia, o anacronismo das jovens regras brasileiras. A experiência internacional mostrou que elas são passíveis de burla sem grandes dificuldades, como se vê pelo efeito cascata que pode elevar a ratio muitas vezes e conseguir um deslocamento de rendas tributáveis para jurisdições menos gravosas. ${ }^{175}$

\footnotetext{
175 O efeito cascata se dá pelo investimento integral do capital dos sócios em arranjo vertical, considerando uma ratio 2:1 e uma participação na empresa mãe de \$1000. Como o empréstimo seria de $\$ 2000$, o total de $\$ 3000$ seria investido na Cia A. Esta ao receber um aporte de $\$ 3000$, permite um empréstimo de $\$ 6000$, que, por sua vez, são investidos na Cia C. Ao final teríamos um empréstimo total de $\$ 8000$ (\$2000+\$6000), muito acima da raio 2:1. Cf. Cf. A.L.M. do R. Monteiro, As regras de subcapitalização adotadas pela Lei 12.249/10 e sua aplicação em situações abrangidas por acordos para evitar a dupla tributação celebrados pelo Brasil, p. 144.
} 


\section{IV.3.5 Compensação de lucros e prejuízos}

Havia, no ordenamento brasileiro, previsão para a compensação de prejuízos fiscais limitada a 4 exercícios posteriores. Com o advento das Leis 8.981/95 e 9.065/95, o regime de tratamento dos prejuízos foi alterado. Manteve-se a possibilidade de compensação, mas a limitação deixou de ser temporal para tornar-se percentual - 30\% do lucro do exercício-, visando a garantir um estável fluxo de ingressos nos cofres públicos. ${ }^{176}$

Por meio de uma limitação interperiódica percentual com finalidade fiscal, o legislador optou por vedar a compensação integral entre prejuízos e lucros produzidos em períodos futuros. Fato é que a legislação autoriza a compensação intraperiódica, ou seja, aquela que considera as deduções para a apuração da base de cálculo do imposto de renda ocorrida em um só período de apuração.

Como já visto, o conceito de renda no ordenamento pátrio é deveras abrangente, compreendendo tanto a noção de acréscimo patrimonial (inc. II do art, 43, CTN), quanto a de renda-produto (inc. I). ${ }^{177}$ Ocorre que, a despeito de haver renda tributada sem que se considere um período de tempo, de forma instantânea - como na tributação exclusiva de rendimentos aos não-residentes- a dinâmica temporal é o que interessa neste ponto, sobremaneira, para que se avance nas análises acerca do resultado líquido dos exercícios produzidos pelas pessoas jurídicas contribuintes do IR. ${ }^{178}$

O resultado líquido disponível constitui acréscimo patrimonial que se subsume ao conceito de renda. Logo, o cálculo da renda-acréscimo não pode prescindir das despesas necessárias anteriormente incorridas para a produção do lucro em um momento subseqüente. Nas palavras de Humberto Ávila, “despesa e lucro mantêm,

\footnotetext{
${ }^{176}$ BRASIL, Lei 8.981/95. Art. 37 Sem prejuízo dos pagamentos mensais do imposto, as pessoas jurídicas obrigadas ao regime de tributação com base no lucro real (...) deverão, para efeito de determinação do saldo de imposto a pagar ou a ser compensado, apurar o lucro real em 31 de dezembro de cada anocalendário ou na data da extinção $\S 5^{\circ}$. O disposto no caput somente alcança as pessoas jurídicas que: (...); b) demonstrarem, através de balanços ou balancetes mensais: (...); b.2) a existência de prejuízos fiscais, a partir do mês de janeiro do referido ano-calendário.

Art.42. A partir de $1^{\circ}$ de janeiro de 1995, para efeito de determinar o lucro real, o lucro líquido ajustado pelas adições e exclusões previstas ou autorizadas pela legislação do Imposto de Renda, poderá ser reduzido em, no máximo, trinta por cento. (incluídos pela Lei 9.065/95).

${ }_{177}^{177}$ V. tópico IV.1.3.

${ }^{178}$ Embora o STF já se tenha pronunciado acerca da renda como acréscimo patrimonial líquido (RE 89.791), entende-se que o conceito constitucional é ainda mais amplo, incluindo renda-produto que não se configure como acréscimo patrimonial. Neste sentido, v. L.E.Schoueri, $O$ mito do lucro real na passagem da disponibilidade jurídica para a disponibilidade econômica, p. 247.
} 
pois, uma relação de causalidade: o lucro posterior é resultado de despesas anteriores (...) o que se ganha depois é resultado do que se investe antes." 179

Não causa espécie que a praticabilidade tenha inspirado o legislador a determinar cortes temporais que permitissem apurar a renda dos contribuintes. Certo é, contudo, que esses cortes podem recair sobre o intercurso do ciclo econômico dos contribuintes, assim entendido o tempo transcorrido entre os gastos com determinado investimento e os ganhos que dele retornam.

Como a renda somente surgirá em momento posterior aos dispêndios, poderá ocorrer de os cortes temporais escolhidos pelo legislador recaírem uma ou mais vezes em fase do ciclo que ainda não tenha havido qualquer retorno ao investidor. Nesta hipótese, ele nada teria a ofertar à tributação em face de resultados negativos que deverá apurar. Tanto mais assim será quanto maior for o ciclo econômico do negócio em questão.

Logo, cumpre indagar se os cortes temporais fixados pela praticabilidade e que vedam a compensação de prejuízos anteriores em percentual superior a $30 \%$ do lucro no período passa pelos testes da competitividade, da submissão harmônica à ordem tributária e à ordem econômica.

A um investidor estrangeiro que se sinta motivado o suficiente para aportar IED no Brasil, questão relevante é justamente o trato da compensação entre lucros e prejuízos na legislação doméstica. Sabedor que a complexidade de seu negócio deverá apresentar proporção com a extensão de seu ciclo econômico, poderá desistir do investimento a depender do tempo que tiver de suportar as despesas antes do lucro. O fator tributário será levado em conta nesses cálculos.

O Brasil, portanto, seria mais competitivo na atração do IED se permitisse a compensação dos prejuízos anteriores com os lucros futuros de forma interperiódica. Assim, estimularia novos investimentos na economia, pois reconheceria um direito do contribuinte a tratar seus resultados em uma dinâmica temporal, perpassando os cortes fixados pelo legislador enquanto não houvesse lucro suficiente para compensar as despesas iniciais e de manutenção.

É legítima a conclusão de que o tratamento conferido à compensação de lucros e prejuízos pelo legislador brasileiro não atende aos reclames da competitividade internacional (teste 1).

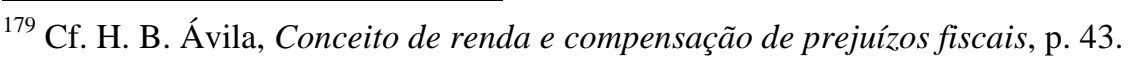


Quanto à ordem tributária (teste 2), não se chega a conclusão distinta. Com efeito, a limitação interperiódica à compensação dos prejuízos apurados em dado período, produz distorções que afetam o princípio da igualdade e da capacidade contributiva.

A questão reside nos cortes temporais escolhidos pelo legislador. Nesse sentido, a praticabilidade é uma concessão aos interesses do Estado, mas jamais absoluta. A mitigação que produz nos efeitos da capacidade contributiva são mais restritivos que o desejável.

Retomando a idéia do ciclo econômico de dois contribuintes, "A" e "B", por hipótese considere-se que a complexidade do negócio do primeiro é maior que a do segundo, retornando seu investimento em maior tempo. Se ambos investem $\$ 100$ por período de apuração, admita-se que "B" recupera $\$ 100, \$ 200$ e $\$ 300$, respectivamente entre o primeiro e o terceiro período, enquanto que "A só recebe \$600 no terceiro e nada antes. Considerando uma alíquota de $10 \%$, a tributação de ambos seria bastante diversa, malgrado apresentem, rigorosamente, o mesmo acréscimo patrimonial líquido.

"B" apuraria resultado positivo (lucro) apenas no $2^{\circ}(\$ 100)$ e no $3^{\circ}$ período (\$200), suportando, ao final de três períodos, \$30 a título de IR. "A" não teria a mesma sorte, pois somente apuraria lucro no $3^{\circ}$ período $(\$ 500)$, obtendo prejuízos $(\$ 100)$ em cada um dos períodos anteriores, arcando com um ônus de $\$ 50$.

Assim seria, caso não houvesse a compensação interperiódica. O resultado produzido avilta o próprio conceito de renda enquanto acréscimo patrimonial líquido, violando a ordem constitucional tributária nos seguintes dispositivos: ${ }^{180}$

(i) competência tributária da União por tributar algo que não renda (art. 153, III, $\mathrm{CF})$;

(ii) princípio do não-confisco, por alcançar não a renda produzida, mas o próprio patrimônio do contribuinte (art. 150, IV) ;

(iii) princípio da igualdade e da capacidade contributiva (art. 150, II e 145, $\S 1^{\circ}$ ), por tratar desigualmente os iguais e ignorar o critério de discrímen exigido pela Constituição ;

(iv) progressividade, pois o aumento da tributação não decorre do aumento de renda, mas da relação com o ciclo econômico do negócio;

(v) legalidade (art. 150, I), pela falta de previsão legal para atingir o elemento quantitativo do conseqüente da hipótese de incidência;

\footnotetext{
${ }^{180}$ Cf. H. B. Ávila, Conceito de renda e compensação de prejuízos fiscais, pp. 49-52.
} 
(v) princípio da justiça, como decorrência do arbítrio e da violação da igualdade que, inexoravelmente, causam iniqüidade no tratamento dos contribuintes (art. $3^{\circ}, \mathrm{I}$ );

A legislação brasileira incorre nas violações acima, pois veda a conexão entre períodos para a apuração da renda. Em outro dizer, sobrevaloriza a praticabilidademera conveniência para o desempenho das funções do Estado - acima dos mais nobres princípios de um Estado Democrático de Direito que visa ao desenvolvimento por meio da proteção da dignidade da pessoa humana. Decerto, porem, que em menor grau que no exemplo, já que há a concessão de um limite de $30 \%$ do lucro para efeito de compensação de prejuízos anteriores.

Sob o crivo da ordem econômica, também merece alteração a opção do legislador, por confrontar-se com alguns de seus princípios (teste 3). O tratamento conferido de forma desigual a dois contribuintes com a mesma capacidade contributiva, ignora questões pessoais relativas à liberdade de ocupação profissional conferida a todos os contribuintes. Daí se infere que poderá haver um desbalanço na concorrência (art. 170, IV, CF) e desestímulo na livre iniciativa (art. 170,CF), já que a depender dos ciclos econômicos de cada ramo de negócios, o tratamento tributário variará. ${ }^{181}$

\section{IV.3.6 Regime Fiscal para Grupos de Empresas- Group Tax Regime}

Um grupo de empresas é um conjunto cujos elementos integrantes são empresas conectadas por um controle comum, exercido em virtude de participação societária e/ou de relações financeiras ou gerenciais. Quando a obrigação tributária das integrantes do grupo pode ser computada de forma consolidada, submetem-se, as empresas relacionadas, a um regime fiscal para grupo de empresas ou group tax regime. $\mathrm{O}$ termo tem alcance semântico mais amplo que somente a consolidação fiscal, abrangendo, ainda, a transferência de características pessoais dos contribuintes, como deduções, créditos e transporte de prejuízos. ${ }^{182}$

\footnotetext{
${ }^{181}$ Cf. H. B. Ávila, Conceito de renda e compensação de prejuízos fiscais, p. 55.

${ }_{182}$ MASUI, Yoshihiro. Group taxation - general report. Cahiers de Droit Fiscal International, vol 89b, Amsterdam: SDU, 2004, p. 25 . O autor analisa o relatório de 30 países sobre regime fiscal de grupos, ressaltando que o material produzido representava, até outubro de 2003, o maior volume produzido acerca do assunto. As dificuldades em avançar sobre o tema decorrem do fato de a abordagem recair sobre subsidiárias no exterior, razão pela qual a International Fiscal Association resolveu se dedicar ao tema e auxiliar as MNEs a superarem as dificuldades enfrentadas sob o direito vigente.
} 
Um dos argumentos favoráveis ao tratamento de um conjunto de empresas independentes como entidade tributável singular reside na neutralidade fiscal. Assumindo, por hipótese, duas divisões de uma mesma empresa que atuem em P\&D e publicidade e que produzam, respectivamente, resultados positivos e negativos em dado período de apuração, dá-se, naturalmente, a compensação desses resultados para a apresentação do resultado final da empresa. Fossem, por outro lado, as divisões em questão mudadas para subsidiárias de uma mesma controladora, sem um regime fiscal especial, o prejuízo da empresa de publicidade não poderia ser compensado com os lucros da empresa de $\mathrm{P} \& \mathrm{D}$, o que, ao final, produziria um resultado ineficiente em termos de alocação de investimento e formas de atuação societária. ${ }^{183}$

Embora utilizado em jurisdições que adotaram tributação consolidada para grupos, esse argumento não está isento de críticas. Afinal, divisões de uma empresa e subsidiárias são entidades distintas no contexto econômico e jurídico, o que já seria suficiente para não lhes garantir um tratamento tributário semelhante. Haveria, ainda, outras questões afetas à política tributária de cada Estado que deveriam ser consideradas, como a eficiência da alocação de recursos e justiça fiscal. ${ }^{184}$

Não é nova a idéia de tratar, do ponto de vista tributário, um grupo de empresas, como entidade singular, já que remonta ao curso da própria história do imposto de renda. ${ }^{185}$ Ao longo do tempo, as jurisdições adotaram sistemas peculiares, de modo que os requisitos a serem preenchidos para se habilitar a um regime fiscal de grupo diferem substancialmente, assim como o tratamento conferido ao grupo consolidado. ${ }^{186}$

Uma classificação uniforme dos regimes fiscais para grupos de empresas seria tarefa árida, pois as regras instituidoras desses regimes foram adotadas por cada jurisdição, ao longo do tempo, por inspiração de regras anteriores somadas às próprias

\footnotetext{
${ }^{183}$ Cf. Y. Masui, Group taxation - general report, pp.34-35.

${ }^{184}$ Cf. Y. Masui, Group taxation - general report, p. 35.

${ }^{185} \mathrm{O}$ desenvolvimento da teoria do regime de tributação de grupo apresenta três fases marcantes: (i) do início do séc. XX até o fim da $2^{\circ}$ Guerra: os regimes eram diferentes do que se tem hoje em dia, pois priorizavam a soma dos lucros obtidos pelos membros e não as perdas e o diferimento. Os regimes eram mandatórios e as alíquotas corporativas, progressivas. Nesse período ocorreram a decisão da mais alta Corte Administrativa da Prússia sobre o Organschaft (1902); a publicação dos Regulations sobre o assunto nos EUA(1917); e a adoção da consolidação fiscal pela Espanha (1942); (ii) após a $2^{\circ}$ Guerra Mundial: período marcado pela previsão legal do regime por diversos países: Dinamarca em 1960; Suécia em 1965, Reino Unido em 1967; França em 1971; Noruega em 1979; Luxemburgo em 1981; México em 1982; Portugal e Finlândia em 1987. A Alemanha positivou o Organschaft em 1969, o que foi feito pela Áustria em 1972; e (iii) desde os anos 90 até os dias atuais: continuou o avanço legislativo sobre o tema, tendo sido efetuadas diversas revisões e atualizações nos modelos já adotados anteriormente além da junção de novos países ao grupo que já adotava, de alguma forma, um corporate tax regime, dentre eles Itália, Japão e Cingapura.. Cf. Y. Masui, Group taxation - general report, p, 26.

Alemanha positivou o Organschaft em 1969

${ }^{186}$ Cf. H.J. Ault e B.J. Arnold, Comparative income taxation, p. 320.
} 
especificidades. Segundo Yoshihiro Masui, essas regras se difundiram mais facilmente pelos países de ambientes jurídicos semelhantes, o que o levou a agrupar os regimes especiais em três subgrupos, além de um quarto em que incluiu os demais regimes malgrado suas variações e inespecificidades, a saber: ${ }^{187}$

(i) Organschaft: idéia comum à Áustria e Alemanha, criada, originalmente pelos tribunais e não pelo legislador. Basicamente, trata as subsidiárias como se fossem divisões internas da empresa controladora. Assim, concentra os lucros e prejuízos das subsidiárias, diretamente, na controladora, não havendo diferimento de lucros ou prejuízos pela transferência de bens ou direitos intragrupo. Para se qualificar ao regime, a empresa dominante deverá deter a maioria das ações de voto nas subsidiárias alemãs, pois o regime é tradicionalmente doméstico. ${ }^{188}$

(ii) Group contribution (nórdicos): permite a troca de renda entre membros do grupo, compensando lucros e prejuízos. O membro que oferta seus lucros deve deduzilos de sua base de cálculo enquanto que aquele que os recebe deve acrescê-los na sua. Adotado na Suécia, Noruega e Finlândia.

(iii) Group relief (common law): admite somente a troca de perdas entre os membros de um grupo. Difere, pois, do group contribution regime por requerer a compensação das perdas com lucros de outros membros. Adotado no Reino Unido, Nova Zelândia e Cingapura. Austrália adotava esse modelo, mas alterou para um complexo e completo regime de consolidação em $2003 .{ }^{189}$

(iv) Regime de Consolidação ou Tax Consolidation: há diversos modelos de consolidação em vigor nas jurisdições que adotam um regime fiscal para grupos de empresas. Apesar das diferenças, é usual cada membro computar, em separado, a renda corporativa. Esta, após alguns ajustes, é reunida para o grupo, competindo à controladora pagar os tributos por todo o grupo. Esse é o regime em voga na Austrália, Dinamarca, França, Itália, Luxemburgo, Espanha, Portugal, México, Japão, Nova Zelândia, Holanda e Estados Unidos.

Já Carlo Garbarino vê apenas dois modelos de tributação para grupos empresariais: regime de consolidação e group relief. Sustenta o professor da Università Bocconi, que os regimes limitam o alcance da consolidação à própria jurisdição

\footnotetext{
${ }^{187}$ Cf. Y. Masui, Group taxation - general report, pp. 29-31.

${ }^{188}$ Cf. H.J. Ault e B.J. Arnold, Comparative income taxation, p. 323.

${ }^{189}$ Cf. H.J. Ault e B.J. Arnold, Comparative income taxation, p. 321.
} 
(consolidação nacional), embora uma autêntica consolidação mundial requeira a presença de elementos transnacionais, estendendo-se a controladas não residentes na jurisdição. ${ }^{190} \mathrm{Na}$ prática, há dificuldades à adoção de um regime de consolidação físcal mundial, pois as perdas de uma subsidiária estrangeira podem ter sido consideradas em seu país de domicílio, afastando nova compensação pela controlada do grupo em outra jurisdição.

Sobre este tema, aos 13 de dezembro de 2005, a Corte Européia de Justiça se pronunciou em Marks \& Spencer. ${ }^{191} \mathrm{O}$ caso tratava de regras de group relief do Reino Unido, por meio das quais seria possível a compensação de perdas de uma empresa com lucros de outra em um mesmo grupo, desde que ambas as empresas fossem residentes no Reino Unido ou lá mantivessem um EP. Marks \& Spencer atuava por meio de subsidiárias na Alemanha, Bélgica e França sem qualquer presença no Reino Unido e pretendia compensar perdas dessas subsidiárias com os lucros da controladora, evocando a liberdade de estabelecimento constante do Tratado da União Européia (arts. 43 e 48). A questão submetida à CEJ, portanto, estava em decidir se restringir o regime de group relief a empresas residentes no Reino Unido contrariava a liberdade fundamental em questão.

A CEJ entendeu não haver motivos para restringir o alcance do regime group relief, especialmente porque as subsidiárias estrangeiras haviam esgotado todas as alternativas de dedução em seus Estados de residência para o exercício fiscal relativo ao pedido de dedução e para exercícios anteriores, não havendo possibilidade de dedução em exercícios futuros, já que duas subsidiárias encerraram suas atividades (Alemanha e Bélgica) e a terceira fora vendida (França). ${ }^{192}$

Marks \& Spencer permite concluir que perdas estrangeiras causam dúvidas ao Estado de residência da controladora do grupo, em razão da possibilidade de haver

190 GARBARINO, Carlo. A consolidação mundial. In: ZILVETI, Fernando Aurélio (coord.), Direito Tributário Atual 25. São Paulo: Dialética, 2011. p. 5. O autor cita Dinamarca, França,Itália e Áustria como jurisdições em que se pode encontrar, atualmente, regimes de consolidação mundial. Yoshihiro Masui destaca a tendência corrente em expandir as regras de consolidação fiscal para estabelecimentos permanentes de empresas não-residentes, especialmente na União Européia. Cf. Y. Masui, Group taxation - general report, pp. 53-55.

191 CORTE EUROPÉIA DE JUSTIÇA. Caso Marks \& Spencer (C-446/03). Disponível em www.curia.europa.eu/juris/liste.jsf?language-en\&num-c-446/03. Acesso em 15 dez 2011.

192 A CEJ entendeu que a legislação comunitária autoriza um membro a impedir a compensação dos lucros de uma controladora residente com as perdas sofridas por subsidiárias em outro Estado-membro. Todavia, uma sociedade controladora residente deveria ser excluída dessa possibilidade nos casos em que a subsidiária não-residente houvesse esgotado todas as possibilidades de compensar suas perdas em seu Estado de residência. Cf. CEJ, C-446/03, Disponível em www.curia.europa.eu/juris/liste.jsf?languageen\&num-c-446/03. Acesso em 15 dez 2011. 
duplo aproveitamento dessas perdas em duas jurisdições. A CEJ autorizou a compensação dessas perdas, legitimando um autêntico regime de consolidação comunitário, mas não de forma absoluta senão que sob o preenchimento dos requisitos acima expostos.

Dois são os objetivos centrais dos grupos corporativos: compensar perdas e lucros dos membros e diferir ganhos reconhecidos pela transferência de bens e direitos intragrupo. Assim, ao confrontar os interesses das MNEs com os regimes adotados pelas diversas jurisdições, conclui-se que muitos consentem, em seu ordenamento, com a compensação e o diferimento em questão. Outros regimes são parciais, cedendo a apenas uma das possibilidades, enquanto outros não autorizam qualquer das possibilidades por não adotarem nenhum regime especial para grupos de empresas. $\mathrm{O}$ Brasil se encontra no rol desses últimos.

Inobstante o artigo 30 do DL 1.598/77 tenha disposto sobre a tributação de sociedades em conjunto, suas regras não tiveram aplicação prática, culminando com sua revogação pelo DL 1.648/78. Desta feita, não vige qualquer regime fiscal para grupos de empresas entre nós.

Garbarino vê o regime CFC brasileiro como uma forma de consolidação mundial parcial ao compará-lo com o sistema italiano que alcança somente renda passiva, mas despreza os prejuízos das subsidiárias. Em todo o caso, o regime CFC brasileiro seria mais abrangente, pois não adota um critério transacional, alcançando todos os rendimentos das controladas. ${ }^{193}$

Em nosso ver, o regime CFC tem escopo diverso de um regime de consolidação, ainda que, por coincidências impositivas, possam se interseccionar. Nesse ponto, o regime CFC brasileiro, se comparado à consolidação, teria por fim aumentar a imposição físcal ao considerar somente os lucros, mas não os prejuízos. Logo, para efeito das análises de conformação nos testes realizados neste tópico, considera-se que não vige um regime de consolidação fiscal no ordenamento brasileiro. ${ }^{194}$

Com o intuito de analisar as diversas possibilidades que o tema oferece, a aplicação dos testes de coerência com as balizas constitucionais será realizada

\footnotetext{
${ }^{193}$ Cf. C. Garbarino, Carlo. A consolidação mundial,p. 7.

${ }^{194}$ Para análise das regras CFC brasileiras, v. tópico IV.3.2. A ausência de previsão normativa sobre consolidação fiscal de grupos empresariais pode estimular o planejamento fiscal, induzindo aos objetivos de compensação ou diferimento. A legislação brasileira já prescreve regras antielisivas, como preços de transferência e subcapitalização, a fim de evitar o deslocamento de lucros para outras jurisdições.
} 
especificamente para um suposto regime de consolidação nacional e um regime de consolidação mundial.

(i) Regime de Consolidação Nacional: neste caso, a controladora e as subsidiárias seriam todas residentes no Brasil. Caso o legislador editasse norma autorizando a consolidação fiscal entre empresas residentes no País, cumpriria averiguar:

(i.a) a relação entre tal norma e a competitividade do País no cenário internacional (teste1): pode-se afirmar que um regime fiscal de grupo seria de interesse para o investidor, que, com segurança, compensaria perdas e lucros entre os membros do grupo - empresas residentes no Brasil. Em se considerando a expansão das empresas para atender aos imperativos do mercado, um regime fiscal de grupo parece um ponto positivo. A essa conclusão se chega independente de o capital de controle do grupo ser brasileiro ou estrangeiro.

(i.b) a conformação de tal norma à ordem tributária e ao conceito de renda vigente (teste 2): justificativas para normatizar um regime fiscal de grupo são decorrentes da desconsideração da independência e da autonomia das pessoas jurídicas. Assim, somente o grupo seria entidade singular. Sob este enfoque, um regime de consolidação pode se basear na neutralidade e na capacidade contributiva.

Sob a égide da neutralidade, todos os rendimentos da atividade do grupo serão tributados do mesmo modo, já que a controladora seria responsável por compilar as informações econômico-fiscais das subsidiárias, sujeitando todo o grupo a uma tributação uniforme. Tratamentos individualizados a membros do grupo restariam afastados. Da mesma forma, a capacidade contributiva de todo o grupo deve se sobrepor à capacidade contributiva de cada empresa-membro, já que o tratamento individualizado poderá resultar em tributação diferente da que resultaria em se considerando todo o grupo.

Neste ponto, andou bem o legislador brasileiro em permanecer silente. Haveria uma quebra de coerência, ferindo a razoabilidade, se ofertasse um tratamento específico a subsidiárias, diferente do que vige no ordenamento pátrio. Em suma, não faria sentido ignorar a personalidade jurídica da empresa para aplicação do regime de grupo, mas considerá-la para aplicação das regras CFC ou das regras de integração. Afinal, a subsidiária é ente dotado de personalidade jurídica para fins físcais. O fato de se não reconhecer pessoas jurídicas independentes e autônomas como meras partes de uma entidade singular, que seria o grupo, não pode causar espécie, pois está conforme o 
princípio da igualdade, na medida em que se confere tratamento desigual a pessoas desiguais.

(i.c) a conformação de tal norma à ordem econômica (teste 3): o objetivo de atração de capitais não é absoluto. Ainda que eventual norma instituindo regime de consolidação satisfaça ao teste 1, deve-se observar limites impostos pela ordem econômica. Assim, ainda que o hipotético regime de grupo vigesse no Brasil, estimulando a expansão de empresas, que, por seu turno, favorecessem a valorização do trabalho humano, a livre iniciativa, a existência digna, enfim, os ditames da justiça social, haveria que ser preservada a livre-concorrência, enquanto autêntico limite à atuação de grupos de empresas. Portanto, a constitucionalidade da norma em comento estaria condicionada à observância da repressão ao abuso do poder econômico que vise à dominação dos mercados e à eliminação da concorrência.

(ii) Regime de Consolidação Mundial: neste caso, assume-se que o investidor estrangeiro detém o controle sobre uma subsidiária residente no Brasil. Caso o legislador editasse norma autorizando a consolidação fiscal mundial, seria de nosso interesse:

(ii.a) a relação entre tal norma e a competitividade do País no cenário internacional (teste1): seria vantajoso ao investidor estrangeiro um regime de consolidação mundial. O Brasil ganharia em atratividade ao IED.

(ii.b) a conformação de tal norma à ordem tributária e ao conceito de renda vigente (teste 2): caso a subsidiária brasileira obtenha lucro ao final do exercício e outra empresa do grupo apresente prejuízo no exterior, o Brasil teria perda de arrecadação. No caso de a subsidiária brasileira apresentar perdas em determinado exercício, o regime de compensação proposto no item precedente resolveria a questão. Conclui-se, pois, que a atração de IED, embora importante, deve encontrar limites. Caso o País editasse norma nesse sentido não teria vantagens a despeito de se tornar mais atrativo ao investidor externo. Ao contrário, além de comprometer receitas, estaria se desviando do conceito de renda, ao combinar lucros/perdas de pessoa jurídica estrangeira ao resultado da brasileira.

(ii.c) ) a conformação de tal norma à ordem econômica (teste 3): neste ponto será lícito repetir as conclusões obtidas quando da análise de um regime de consolidação nacional, porém considerando haver maior razão para evocar os limites da 
livre-concorrência e preservação do mercado, pois que neste cenário é possível haver empresas ainda maiores (controladoras internacionais) que no cenário anterior. 


\section{IV.4 CONCLUSÕES DO CAPÍTULO}

IV.4.1. Na terminologia do art. 43 do CTN, o imposto de renda terá, como fato gerador, a aquisição da disponibilidade econômica ou jurídica de:

I - de renda, assim entendido o produto do capital, do trabalho ou da combinação de ambos;

II - de proventos de qualquer natureza, assim entendidos os acréscimos patrimoniais não compreendidos no inciso anterior.

Logo, foram positivadas a teoria da renda-produto, segundo a qual a renda seria o fruto periódico de uma fonte permanente, reconhecido somente na ocasião em que o primeiro se separa da segunda, o que se entende por realização; e a teoria da renda-acréscimo, de modo que renda seria o saldo positivo dos acréscimos patrimoniais aferido de forma dinâmica, em cortes temporais. Com isso, vê-se que os contornos do conceito de renda fixados pelo legislador complementar foram bastante amplos.

IV.4.2. O Estado dispõe de um leque de opções para definir a forma pela qual pretende tributar investimentos internacionais. Típicas escolhas recaem sobre o tratamento tributário que será conferido a dividendos sob o IRPJ e IRPF; prioridade para a eficiência/neutralidade na escolha de um sistema; escolha por manter, reduzir ou eliminar bitributação econômica; aliviá-la ao nível da empresa ou do acionista; escolher o método mais apropriado para aliviá-la; definir sobre alíquotas, base de tributação e concessão de incentivos fiscais.

IV.4.3. Após o estudo do exame de proporcionalidade como único meio capaz de maximizar, concomitantemente, os efeitos da indução e o respeito à capacidade contributiva, passa-se à aplicação de testes de constitucionalidade sobre alguns institutos típicos da tributação internacional da renda. O objetivo dessas análises é identificar se cada um desses institutos se conforma ao ordenamento brasileiro sob três diferentes ângulos: o primeiro considera a atuação do legislador vinculada à promoção do desenvolvimento, o que, neste estudo, significa investigar se a norma tributária promove a atração de IED; (ii) o segundo diz da sujeição da norma à ordem tributária, especialmente pelo crivo da capacidade contributiva e demais princípios como legalidade e segurança jurídica; e (iii) o último avalia a norma tributária à luz da ordem econômica, sob o imperativo da preservação da livre concorrência, livre iniciativa e 
outros objetivos perseguidos pela Constituição Econômica. Os resultados da aplicação dos testes de conformação ao ordenamento pátrio são apresentados a seguir.

IV.4.4. QUADRO SINÓTICO DOS TESTES DE CONSTITUCIONALIDADE SOBRE REGRAS DE TRIBUTAÇÃO INTERNACIONAL DA RENDA

\begin{tabular}{|c|c|c|c|}
\hline & $\begin{array}{c}\text { Teste 1 } \\
\text { Atração ao IED/ } \\
\text { Competitividade }\end{array}$ & $\begin{array}{c}\text { Teste 2 } \\
\text { Ordem Tributária }\end{array}$ & $\begin{array}{c}\text { Teste } 3 \\
\text { Ordem Econômica }\end{array}$ \\
\hline $\begin{array}{l}\text { Integração - } \\
\text { Regra de } \\
\text { isenção de } \\
\text { dividendos }\end{array}$ & $\begin{array}{l}\text { Não satisfeito. Medida } \\
\text { praticamente inócua quanto ao } \\
\text { investidor não-residente }\end{array}$ & $\begin{array}{l}\text { Não satisfeito. Medida } \\
\text { reprovada no exame de } \\
\text { proporcionalidade }\end{array}$ & Satisfeito. \\
\hline Regras CFC & $\begin{array}{l}\text { Inaplicável, } \\
\text { se o fim for atração do IED. } \\
\text { Não satisfeito, se o fim for a } \\
\text { competitividade do Brasil. }\end{array}$ & $\begin{array}{l}\text { Não satisfeito. } \\
\text { Fere igualdade, } \\
\text { capacidade contributiva } \\
\text { e proporcionalidade. }\end{array}$ & $\begin{array}{l}\text { Não satisfeito. } \\
\text { Há violação da } \\
\text { neutralidade } \\
\text { concorrencial, da livre } \\
\text { concorrência e da livre } \\
\text { iniciativa. }\end{array}$ \\
\hline $\begin{array}{l}\text { Preços de } \\
\text { Transferência }\end{array}$ & Satisfeito. & $\begin{array}{l}\text { Satisfeito parcialmente. } \\
\text { Há violações à } \\
\text { igualdade, segurança } \\
\text { jurídica por regras de } \\
\text { juros não registrados no } \\
\text { BACEN, regra do } \\
\text { método mais favorável, } \\
\text { regras de porto seguro. }\end{array}$ & Satisfeito. \\
\hline $\begin{array}{l}\text { Regras de } \\
\text { subcapitaliza } \\
\text { ção }\end{array}$ & Satisfeito. & Satisfeito. & Satisfeito. \\
\hline $\begin{array}{l}\text { Compensação } \\
\text { de Lucros e } \\
\text { Perdas }\end{array}$ & Não satisfeito. & $\begin{array}{l}\text { Não satisfeito. } \\
\text { Concessões à } \\
\text { praticabilidade } \\
\text { restringem mais que o } \\
\text { tolerável a capacidade } \\
\text { contributiva. }\end{array}$ & $\begin{array}{l}\text { Não satisfeito. } \\
\text { Violações potenciais à } \\
\text { liberdade de ocupação } \\
\text { profissional, livre } \\
\text { iniciativa e livre } \\
\text { concorrência. }\end{array}$ \\
\hline $\begin{array}{l}\text { Regime de } \\
\text { Consolidação } \\
\text { Fiscal } \\
\text { Nacional }\end{array}$ & Satisfeito. & $\begin{array}{l}\text { Não satisfeito. } \\
\text { Potencial violação ao } \\
\text { conceito de renda. }\end{array}$ & $\begin{array}{l}\text { Satisfeito, desde que se } \\
\text { reprima o abuso do } \\
\text { poder econômico que } \\
\text { vise à dominação dos } \\
\text { mercados e à } \\
\text { eliminação da } \\
\text { concorrência. } \\
\text { Satisfeito, desde que se } \\
\text { reprima o abuso do } \\
\text { poder econômico que } \\
\text { vise à dominação dos } \\
\text { mercados e à } \\
\text { eliminação da } \\
\text { concorrência. }\end{array}$ \\
\hline
\end{tabular}




\section{CONCLUSÕES}

V.1. A formação de um ambiente favorável ao investidor externo representa uma das alternativas à promoção do desenvolvimento. Esta é uma tarefa a que se vê jungido o legislador brasileiro, pela resultante dos vetores que informam as ordens tributária e econômica, configurando o Estado Democrático de Direito, fundamentado pela dignidade da pessoa humana e pelos valores sociais da livre iniciativa $\left(\mathrm{CF}\right.$, art. $\left.1^{\circ}\right)$. Em plena concorrência internacional, inaceitável a norma que atue em desfavor da jurisdição brasileira, beneficiando outro Estado. Por conseguinte, o legislador deve, ao efetuar suas opções em matéria de tributação da renda, atuar para a criação e o desenvolvimento de um contexto propício aos fluxos de IED. Ideal seria que as edições normativas fossem coerentes e respeitassem uma política claramente voltada para esta finalidade, evitando que regras concernentes a um dado instituto contrariassem normas outras já previstas no ordenamento brasileiro.

V.2. A $5^{\mathrm{a}}$ posição na lista mundial de destinos de fluxos de IED foi recém-conquistada pelo Brasil. ${ }^{1}$ Independente de o mercado brasileiro dispor de outros atrativos (fatores específicos espaciais), sabe-se que a estrutura pública de um País é considerada pelo investidor cauteloso. Por conseguinte, a atuação legislativa em diversas áreas deve ser harmônica, voltada para o mesmo fim. Na seara da tributação, restou concluso que legislação concessiva de incentivos fiscais não estaria, necessariamente, cumprindo com a meta de atrair IED. A decisão de alocação do capital enfrenta vários fatores específicos da empresa e espaciais, constituindo-se a tributação em apenas um desses últimos.

V.3. A atração do investidor externo não se restringe à redução de alíquotas ou de imposição fiscal. Estados competitivos podem definir uma política que não se baseie, exclusivamente, na renúncia de receitas. Certo é que a atuação do legislador para atrair IED deve ser feita de modo conjunto pelas normas tributárias voltadas para fiscalidade e para indução. A obrigação de respeitar ao máximo a igualdade entre os contribuintes e

\footnotetext{
1 UNCTAD, World Investment Report 2011. Disponível em: http://www.unctad.org/Templates/webflyer.asp?docid=15189\&intItemID=2068\&lang=1 \&mode=downloa ds. Acesso em 10 out 2011.
} 
de induzir o agente econômico a determinado objetivo, exige conformação à proporcionalidade, sob pena de violação constitucional.

V.4. A participação dos agentes privados na consecução de objetivos sócio-econômicos constitucionalmente previstos é bastante desejável. Por vezes o Estado apóia a participação privada por meio de subvenção direta, desembolsando recursos levados a registro na coluna das despesas públicas. Entretanto, a preferência brasileira mais recentemente tem sido a renúncia de receitas ou gastos tributários, que não chegam a constar da coluna das receitas que deveriam ingressar nos cofres públicos.

V.5. Gastos tributários exigem controle baseado em critério claramente definido, que, ao demais, deve ser exercitado de forma uniforme, atingindo a todos jurisdicionados na mesma medida. Favorece a criação de um ambiente seguro ao investidor externo a oferta de incentivos de modo transparente, sem que se beneficie em maiores proporções a determinados segmentos ou atividades. Esta é uma imposição resultante da igualdade e da livre concorrência.

V.6. A questão dos incentivos fiscais em matéria tributária apresenta dimensão internacional. Com efeito, os acordos bilaterais para evitar a bitributação, a despeito da terminologia empregada para se lhes identificar, prestam-se, igualmente, a outros fins, dentre os quais a promoção do desenvolvimento. Nesta esteira, é usual a negociação para inclusão de cláusulas de incentivo (tax sparing e matching credit) no texto dos acordos. Em geral, a fonte ofertaria incentivos fiscais e a residência concordaria em não alcançar os rendimentos beneficiados pela fonte.

V.7. As cláusulas de incentivo nos acordos de bitributação podem ser entendidas como medida de estímulo ao desenvolvimento da fonte com a anuência da residência. Em sua proposta inicial, os fluxos de investimento não seriam correlatos, costumando abranger negociações entre países exportadores de capital e países importadores de capital. Atualmente, com o fortalecimento econômico de alguns países deste último grupo, por vezes tem sido negociada uma cláusula de incentivo mútua em acordos de bitributação celebrados entre emergentes. Trata-se de medida atrativa ao IED, moldada para atender aos interesses de exportadores e importadores recíprocos. 
V.8. O Brasil, embora negocie acordos de bitributação há meio século, dispõe de menos de 30 acordos em vigor. Outros concorrentes brasileiros possuem o dobro e até o triplo do número de acordos brasileiros. Em nosso ver, a construção planejada de ampla rede de acordos de bitributação é crucial para o interesse de Estados que pretendam assegurar sua inserção internacional. Neste ponto, o Brasil deve rever sua política de acordos tributários, escolhendo novos parceiros e ampliando as condições de segurança e transparência ao investidor estrangeiro.

V.9. A atuação coordenada não apenas do legislador, mas de autoridades do Executivo e do Judiciário, exige formulação de política voltada para atratividade do IED. Neste ponto, à guisa de ilustração, tome-se o exemplo da norma que isentou os dividendos com o fim de aliviar a bitributação econômica (Lei 9.294/95, art. 10). Conforme as análises no tópico IV.3.1, o problema da bitributação sobre a mesma corrente de lucros não foi resolvido. Uma alternativa para aumentar a eficácia da norma seria a concessão de crédito indireto nos acordos de bitributação. Daí se conclui que o Brasil, para obter ainda mais sucesso na atração do IED, deve erigir estrutura sistêmica que abranja Executivo, Legislativo e Judiciário e atue de forma clara, segura e justa, favorecendo o influxo de investimentos.

V.10. O resultado dos testes de coerência e conformação à ordem constitucional vigente no Brasil indica que, em matéria de tributação da renda, a atuação do legislador infraconstitucional nem sempre confere maior competitividade ao País. De fato, regras brasileiras de integração, CFC e de compensação de lucros e prejuízos foram rejeitadas pelo teste de concorrência internacional. Nestes casos, satisfazer aos demais testes é indiferente à violação de mandamento constitucional. Considerando a vinculação do legislador brasileiro à formação de um ambiente propício aos fluxos de IED, urge alterar o conteúdo dessas regras para que promovam a competitividade brasileira.

V.11. Os testes referentes à ordem tributária (conceito de renda) e à ordem econômica também foram desrespeitados em diversos institutos. Entretanto, percebeu-se que a norma aprovada no teste da concorrência internacional costuma satisfazer os princípios da ordem tributária e econômica (preços de transferência, subcapitalização, consolidação nacional). Por oposto, os reprovados no teste 1 dificilmente satisfazem aos demais (integração, CFC e de compensação de lucros e prejuízos). Isso indica que 
a Constituição, ao valorizar os princípios do Estado Democrático de Direito, já atuara na promoção da competitividade nacional, demarcando os rumos da configuração de um ambiente econômico sadio, favorável à livre iniciativa e à dignidade humana, em que se promova o bem de todos e as desigualdades sejam reduzidas ou mesmo eliminadas. Em outro dizer, o constituinte, paralelamente à elaboração dos vetores informadores das ordens tributária e econômica, já impregnara a incumbência do legislador infraconstitucional (de promover competitividade) desses mesmos valores.

V.12. Por fim, o resultado dos testes não permite concluir que o Brasil tenha atuado, de forma planejada, pondo em prática uma ampla e arquitetada política competitiva consoante à legislação do imposto de renda. Para isso, deveria haver coerência entre os institutos, cujos efeitos promoveriam resultados mais próximos. Parece mais lógico supor que o alto volume de influxos de IED que tem aportado no País resulte, entre outros fatores específicos espaciais, de pontuais incentivos trazidos pelo legislador, somados a um quê de estabilidade e modernização da legislação do imposto de renda pós-real. Certo é que tais resultados poderiam ser ainda mais expressivos atuasse o legislador de forma coerente, em respeito aos imperativos constitucionais, na promoção da competitividade do Brasil. 


\section{BIBLIOGRAFIA}

ACCIOLY, Hildebrando, SILVA, G. E. do Nascimento, e CASELLA, Paulo B. Manual de direito internacional público, 17. ed., São Paulo: Saraiva, 2009.

ALMEIDA, Aloísio Flávio F. de. A tributação dos lucros e o retorno ao investimento no Brasil. In: Secretaria do Tesouro Nacional/Coletânea de Monografias. Finanças Públicas, IX Prêmio Tesouro Nacional -2004. Brasília-DF: editora UNB, 2005. p. 461 a 506.

ALMEIDA, Aloísio Flávio Ferreira de. Tax havens: an analysis of the OECD work with policy recommendations. Disponível em: http://www.receita.fazenda.gov.br/Publico/estudotributarios/TrabAcademicos/Resumos/ AloisioTaxHavensabstract.pdf. Acesso em: 10 nov 2011.

ALMEIDA FILHO, João Genésio. O fórum de diálogo Índia, Brasil e África do Sul (IBAS): análise e perspectivas. Brasília: Fundação Alexandre Gusmão, 2009.

AMED, Fernando José; NEGREIROS, Plínio J. L. de Campos. História dos tributos no Brasil. São Paulo: Edições Sinafresp, 2000.

ARNAUD, André-Jean. $O$ direito entre modernidade e globalização: lições de filosofia do direito e do Estado. Tradução de Patrice Charles Wuillaume. Rio de Janeiro: Renovar, 2000.

ARNOLD, Brian J.; DIBOUT, Patrick. Limits on the use of low-tax regimes by multinational businesses: current measures and emerging trends general reports. In: Cahiers de droit fiscal international, vol. LXXXVI b. Hague: International Fiscal Association, 2001, pp. 25-89.

AULT, Hugh J.; ARNOLD, Brian J. Comparative income taxation - a structural analysis. 2 ed. New York: Aspen Publishers, 2004.

ÁVILA, Humberto Bergmann. Comportamento anticoncorrencial e direito tributário. In: FERRAZ, Roberto Catalano Botelho (coord.), Princípios e limites da tributação 2. São Paulo: Quartier Latin, 2009. pp. 427-440.

ÁVILA, Humberto Bergmann. Conceito de renda e compensação de prejuízos fiscais. São Paulo: Malheiros Editores, 2011.

ÁVILA, Humberto Bergmann. Legalidade tributária multidimensional. In: FERRAZ, Roberto Catalano Botelho (coord.), Princípios e limites da tributação. São Paulo: Quartier Latin, 2005. pp. 277-292.

ÁVILA, Humberto Bergmann. Teoria da igualdade tributária, 2. ed. São Paulo: Malheiros Editores, 2009. 
ÁVILA, Humberto Bergmann. Teoria dos princípios - da definição à aplicação dos princípios jurídicos, 10. ed. São Paulo: Malheiros Editores, 2009.

AVI-YONAH, Reuven S. International tax as international law: an analysis of the international tax regime. Cambridge: Cambridge University Press, 2007.

AVI-YONAH, Reuven S. Os três objetivos da tributação. In: COSTA, Alcides Jorge; SCHOUERI, Luís Eduardo e BONILHA, Paulo Celso Bergstrom (coord.), Direito Tributário Atual 22. São Paulo: Dialética, 2008. pp. 7-29.

AVI-YONAH, Reuven S. Pessoas jurídicas, sociedade e o estado: uma defesa do imposto das pessoas jurídicas. In: COSTA, Alcides Jorge; SCHOUERI, Luís Eduardo e BONILHA, Paulo Celso Bergstrom (coord.), Direito Tributário Atual 21. São Paulo: Dialética, 2007. pp. 12-60.

AVI-YONAH, Reuven S. The OECD harmful tax competition report: a tenth anniversary retrospective. University of Michigan Law School, Working Paper No. 115, 2008. Disponível em: http://ssrn.com/abstract=1194942. Acesso em: 05 set 2011.

AVI-YONAH, Reuven S. Globalization, tax competition and the fiscal crisis of the welfare state. Harvard Law School, Working Paper $\mathrm{n}^{\circ} 4,2000$. Disponível em: http://ssrn.com/abstract=208748. Acesso em: 05 set 2011.

BANDEIRA, Luiz Alberto Moniz. Geopolítica e política exterior: Estados Unidos, Brasil e América do Sul. Brasília: Fundação Alexandre Gusmão, 2009.

BAKER, Philip. The concept of tax haven: a legal analysis, London, 2002.

BALZANI, Francesca. Transfer pricing. In: UCKMAR, Victor; ALTAMIRANO, Alejandro C.; TÔRRES, Heleno T. Impuestos sobre el comercio internacional. Buenos Aires: Editorial Abaco de Rodolfo Depalma, 2003.

BARROSO, Luís Roberto. Interpretação e aplicação da Constituição: fundamentos de uma dogmática constitucional transformadora, 6. ed. São Paulo: Saraiva, 2004.

BEHRNDT, Marco A. G. e LOBO, Diana P. B. Dever de o contribuinte apurar ou apenas mostrar os lucros auferidos por filiais, sucursais e controladas no exterior segundo a Legislação Brasileira? In: In FILHO, Clóvis Panzarini et al (Coord.). Revista de direito Tributário Internacional, ano 5, nº13, p.111.

BIANCO, João Franciso. Transparência fiscal internacional. São Paulo: Dialética, 2007.

BITTKER, Boris; LOKKEN, Lawrence. Fundamentals of international taxation. NY: WG\&L RIA, 2008/2009.

BRASIL. Secretaria da receita Federal. Tributação da renda no Brasil pós-real. Brasília: Dupligráfica, 2001. 
BRAUNER, Yariv. Revisitando a (in)sensatez do imposto de renda das pessoas jurídicas. In: COSTA, Alcides Jorge; SCHOUERI, Luís Eduardo e BONILHA, Paulo Celso Bergstrom (coord.), Direito Tributário Atual 21. São Paulo: Dialética, 2007. pp. 61-102.

BRAUNER, Yariv. Direito do comércio internacional e acordos tributários. In: COSTA, Alcides Jorge; SCHOUERI, Luís Eduardo e BONILHA, Paulo Celso Bergstrom (coord.), Direito Tributário Atual 23. São Paulo: Dialética, 2009. pp. 11-40.

BROE, Luc de. International tax planning and prevention of abuse. Amsterdam: IBFD, 2008.

BULHÕES PEDREIRA, José L. Imposto sobre a renda - pessoas jurídicas, v. 1.Rio de Janeiro:Justec, 1979. pp. 369-373.

BURKE, J. Martin.; FRIEL, Michael K. Taxation of individual income. 6th ed. NJ: LexisNexis, 2002.

CAMPILONGO, Celso Fernandes. $O$ direito na sociedade complexa. São Paulo: Max Limonad, 2000.

CASELLA, Paulo Borba. BRIC: Brasil, Rússia, Índia, China e África do Sul: uma perspectiva de cooperação internacional. São Paulo:Atlas, 2011.

CASELLA, Paulo Borba Direito internacional tributário brasileiro, 2 ed., São Paulo: Saraiva, 2009.

CASTAGNÈDE, Bernard. Précis de fiscalité internationale, 2 ed. Paris: Presses Universitaires de France, 2006.

CASTELON, Marta Oliveros. Perspectivas de novo acordo Brasil-Alemanha. In: Filho, C.P.; Tonani, F.; Behrndt M.A.; Ribeiro, R.P; Vasconcellos, R.F. (coord.), Revista de direito tributário internacional. Ano 3, nº8, São Paulo: Quartier Latin, 2008, pp.155-172.

CASTRO, Leonardo Freitas de Moraes e; FILHO, Sérgio Papini de Mendonça Uchoa. Thin capitalization rules no direito comparado e as regras de subcapitalização brasileiras. In: Filho, C.P.; Tonani, F.; Behrndt M.A.; Ribeiro, R.P; Vasconcellos, R.F. (coord.), Revista de direito tributário internacional. Ano 5, $\mathrm{n}^{\circ} 15$, São Paulo: Quartier Latin, 2010, pp.169-211.

COOTER, Robert; ULLEN, Thomas. Direito e economia, 5. ed. Porto Alegre: Bookman, 2010.

COSTA, Regina Helena. Praticabilidade e justiça tributária. São Paulo: Malheiros Editores, 2007.

COUZIN, Robert. Corporate residence and international taxation. Amsterdam: IBFD, 2002. 
DINH, Nguyen Quoc; DAILLIER, Patrick; PELLET, Alain. Direito internacional público, 2 ed. Tradução de COELHO, Vítor Marques. Lisboa: Fundação Calouste Gulbekian, 2003.

DINIZ, Antônio Carlos. Pós-modernismo. In: BARRETTO, Vicente de Paulo (Coord.). Dicionário de Filosofia do Direito. São Leopoldo-RS: Unisinos, 2006, pp.647-650.

DOERNBERG, Richard L. International taxation in a nutshell. $5^{\text {th }}$ ed. Saint Paul, Minn: West Group, 2001.

DOLINGER, Jacob. Direito internacional privado (parte especial) - direito civil internacional - vol. II - Contratos e obrigações no direito internacional privado. Rio de Janeiro: Renovar, 2007.

EDWARDS, Chris; MITCHELL, Daniel J. Global tax revolution: the rise of tax competition and the battle to defend it. Washington, D.C.: CATO Institute, 2008.

ELALI, André. A crise financeira global sob a ótica da concorrência fiscal internacional. In: COSTA, Alcides Jorge; SCHOUERI, Luís Eduardo e BONILHA, Paulo Celso Bergstrom (coord.), Direito Tributário Atual 23. São Paulo: Dialética, 2009. pp. 88-102.

ELALI, André. Incentivos fiscais internacionais - concorrência fiscal, mobilidade financeira e crise do Estado. São Paulo: Quartier Latin, 2010

ENGELEN, Frank. Interpretation of tax treaties under international law. Amsterdam: IBFD, 2004.

FARIA, José Eduardo. O direito na economia globalizada. São Paulo: Malheiros Editores, 2000.

FERNANDES, Edison Carlos. Paz tributária entre as nações- teoria da aproximação tributária na formação dos blocos econômicos. São Paulo: MP, 2006.

FERRAZ, Roberto. Igualdade na tributação - qual o critério que legitima discriminações em matéria fiscal? in Roberto Ferraz (org.), Princípios e limites da tributação. São Paulo: Quartier Latin, 2005

FILHO, João Genésio de Almeida, O fórum de diálogo Índia, Brasil e África do Sul (IBAS): análise e perspectivas. Brasília: Fundação Alexandre de Gusmão, 2009.

FONTANA, Renata. The Uncertain Future of CFC Regimes in the Member States of the European Union - Part 1, In: 46 European Taxation 6. IBFD, Amsterdam: 2006, pp. 259-267.

FORGIONE, Paula A. Os fundamentos do antitruste, 2. ed. São Paulo: Revista dos Tribunais, 2005. 
GARBARINO, Carlo. A consolidação mundial. In: ZILVETI, Fernando Aurélio (coord.), Direito Tributário Atual 25. São Paulo: Dialética, 2011. pp. 5-19.

GONÇALVES, Reinaldo et al. A nova economia internacional: uma perspectiva brasileira. Rio de Janeiro: Campus, 1998.

GRAU, Eros Roberto. A ordem econômica na Constituição de 1988 interpretação e crítica. 8.ed. São Paulo: Malheiros editores, 2003.

GREGORIO, Ricardo Marozzi. Proporcionalidade e tributação direta no direito comunitário europeu. In: COSTA, Alcides Jorge; SCHOUERI, Luís Eduardo e BONILHA, Paulo Celso Bergstrom (coord.), Direito Tributário Atual 23. São Paulo: Dialética, 2009. pp. 490-508.

GREGORIO, Ricardo Marozzi. Um regime para a tributação internacional: perspectivas para o Brasil. In: COSTA, Alcides Jorge; SCHOUERI, Luís Eduardo; BONILHA, Paulo Celso Bergstrom e ZILVETI, Fernando Aurelio (coord.), Direito Tributário Atual 24. São Paulo: Dialética, 2010. pp. 464-487.

GUTMANN, Daniel. Do direito à filosofia do tributo. In: FERRAZ, Roberto Catalano Botelho (coord.), Princípios e limites da tributação. São Paulo: Quartier Latin, 2005. pp. 27-40.

GUTMANN, Daniel. Qual justiça fiscal para os países em desenvolvimento em um mundo globalizado? In: COSTA, Alcides Jorge; SCHOUERI, Luís Eduardo e BONILHA, Paulo Celso Bergstrom (coord.), Direito Tributário Atual 23. São Paulo: Dialética, 2009. pp. 41-49.

HINNEKENS, L. How OECD proposes to apply existing criteria of jurisdiction to tax profits arising from cross-border electronic commerce. In: Intertax, v. 29, pp.322331.

HOEKMAN, Bernard; KOSTECKI, Michel. The political economy of the world trading system. 2. ed. Oxford University Press, 2001.

HOLMES, Kevin. The concept of income - a multidisciplinary analysis. Amsterdam: IBFD, 2001

HUCK, Hermes Marcelo. Evasão e elisão:rotas nacionais e internacionais do planejamento tributário. São Paulo:Saraiva, 1997.

IRISH, Charles R. Tax havens. In: Vanderbilt journal of transnational law, v. 15, $n^{o} 3.1982$. pp. 451-507.

JÚNIOR, Durval de Noronha Goyos. Noronha dicionário jurídico. 5 ed. São Paulo: Observador Legal, 2003. 
Jr. McLURE, Charles E. Globalization, tax rules and national sovereignty. In: Bulletin for International Fiscal Documentation, Amsterdam, IBFD, August/2001, pp. 328-341

LANG, Joachim. A tributação das empresas no contexto da concorrência internacional. In: ZILVETI, Fernando Aurélio (coord.), Direito Tributário Atual 25. São Paulo: Dialética, 2011. pp. 20-47.

LANG, Michael (Ed.). Recent tax treaty developments around the globe. Series on International Tax Law Univ - Prof. Dr. Michael Lang ( Ed.). Vol. 59. Viena: Linde Werlag Wien Ges.m.b.H., 2009.

KELSEN, Hans. Teoria pura do direito. Tradução: João Baptista Machado. 6. ed. São Paulo: Martins Fontes, 2000.

LEE, Chang Hee. Impact of electronic commerce on allocation of tax revenue between developed and developing countries, Ad Hoc Group of Experts on International Cooperation in Tax Matters, $11^{\text {th }}$ Meeting, Genebra, 2003.

LEMGRUBER, Andréa. A tributação do capital: o imposto de renda da pessoa jurídica e o imposto sobre operações financeiras. In: BIDERMAN, Ciro e ARVATE, Paulo (orgs.). Economia do setor público no Brasil. Rio de Janeiro: Elsevier. 2004, pp. 206-215.

LEMGRUBER, Andréa; VILLELA, Luiz. O desafio de medir os gastos tributários. In: SOUSA, M.C.S.de; COELHO, I.; VERSIANI, F.R.; TANNURI-Pianto, M.E. (org.), Economia pública brasileira. Brasília: Escola de Administração Fazendária, 2010, pp.179-201.

LEVINE, Howard J., WEINTRAUB, David A. When Does E-Commerce Result in a Permanent Establishment? The OECD's Initial Response. In: 29 Tax Management International J. 220, 2000.

MAGALHÃES, José Carlos de. Direito Econômico Internacional. Curitiba: Juruá, 2006.

MAGALHÃES, José Carlos de. "Fatores de Limitação da Jurisdição do Estado", in MERCADANTE, Araminta de Azevedo e MAGALHÃES, José Carlos de (coords.). Solução e Prevenção de Litígios Internacionais. vol. II, Porto Alegre, Livraria do Advogado, 1999.

MALHERBE, Jacques. O abuso de direito. Uma análise no direito comparado. In: COSTA, Alcides Jorge; SCHOUERI, Luís Eduardo e BONILHA, Paulo Celso Bergstrom (coord.), Direito Tributário Atual 22. São Paulo: Dialética, 2008. pp. 30-52.

MALHERBE, Jacques. Controlled foreign corporations: revisitadas à luz dos tratados de bitributação e do direito comunitário europeu. In: COSTA, Alcides Jorge; SCHOUERI, Luís Eduardo e BONILHA, Paulo Celso Bergstrom (coord.), Direito Tributário Atual 21. São Paulo: Dialética, 2007. pp. 103-119. 
MALHERBE, Jacques. Ascensão e queda dos incentivos fiscais no cenário internacional. In: COSTA, Alcides Jorge; SCHOUERI, Luís Eduardo e BONILHA, Paulo Celso Bergstrom (coord.), Direito Tributário Atual 23. São Paulo: Dialética, 2009. pp. 50-71.

MARCHI, Eduardo. C. Silveira. Guia de Metodologia Jurídica, 2. ed. São Paulo: Saraiva, 2009.

MASUI, Yoshihiro. Group taxation - general report. Cahiers de Droit Fiscal International, vol 89b, Amsterdam: SDU, 2004. pp.23-67.

MAZZUOLI, Valerio de O. Curso de direito internacional público. São Paulo: Revista dos Tribunais, 2006.

MELLO, Celso D. de Albuquerque. Curso de direito internacional público, 15 ed., Rio de Janeiro: Renovar, 2004.

MOLINA, Pedro M.H. e VASCO, Domingo C. Marco conceptual, constitucional y comunitário de La fiscalidad ecológica. In: TÔRRES, Heleno T. (org.). Direito tributário ambiental. São Paulo: Malheiros Editores, 2005.

MONTEIRO, Alexandre Luiz Moraes do Rêgo. As regras de subcapitalização adotadas pela Lei 12.249/10 e sua aplicação em situações abrangidas por acordos para evitar a dupla tributação celebrados pelo Brasil. In: COSTA, Alcides Jorge; SCHOUERI, Luís Eduardo e BONILHA, Paulo Celso Bergstrom; ZILVETI, Fernando Aurélio (coord.), Direito Tributário Atual 24. São Paulo: Dialética, 2010. pp. 136-156.

MORCHON, Gregorio Robles. Teoria del derecho (Fundamentos de teoría comunicacional del derecho). V. 1. 2.ed. Cizur Menor: Thomsom Civitas, 2006

NOVOA, César García. Reflexiones sobre la influencia de la Globalización en los Principios Tributarios. In: TÔRRES, Heleno Taveira (coord.). Direito tributário internacional aplicado. São Paulo: Quartier Latin. 2003.

NUSDEO, Fábio. Curso de Economia: introdução ao direito econômico, 2. ed. . São Paulo: Revista dos Tribunais, 2000.

OCAMPO, Raúl Granillo. Direito internacional público da integração. Rio de Janeiro, Elsevier, 2009.

OCDE, Taxing profits in a global economy- domestic and international issues, OECD, Paris, 1991, ISBN 92-64-13596-0

OLIVEIRA, Ricardo Mariz de. Fundamentos do imposto de renda. São Paulo: Quartier Latin, 2008.

ORSINI, Elen Peixoto. O Princípio “Arm's Length” e a legislação interna brasileira. In: SCHOUERI, L.E.; ROCHA, V. de O. (coords.). Tributos e preços de transferência. São Paulo: Dialética, 1999. 
O'SHEA, Tom. Direito tributário europeu. In: COSTA, Alcides Jorge; SCHOUERI, Luís Eduardo e BONILHA, Paulo Celso Bergstrom (coord.), Direito Tributário Atual 19. São Paulo: Dialética, 2005. pp. 103-118.

O’SHEA, Tom. Tributação de dividendos pós-Manninen: areia movediça ou fundações sólidas? In: FILHO, Clóvis Panzarini et al (Coord.). Revista de Direito Tributário Internacional, Ano 4, n. 11. São Paulo: Quartier Latin, 2009.

PAÇO, Daniel Hora do; ROSENBLOOM, H. David. Considerações sobre a negociação de um tratado para evitar a dupla tributação da renda com os EUA. In: ROCHA, Valdir de Oliveira (dir.), Revista Dialética de Direito Tributário 174. São Paulo: Dialética, março 2010. pp. 16-26.

PACHECO, Ricardo. Inserção na economia global: uma reapreciação. Pesquisas no 8. São Paulo: Fundação Konrad-Adenauer-Stiftung, 1997.

PERES, Eliane Lamarca Simões. O preço de transferência e a harmonização tributária no MERCOSUL. Rio de Janeiro: Lumen Juris, 2002.

PIRES, Adílson Rodrigues. Controle de preço de transferência e as operações de comércio exterior. In: SCHOUERI, L.E.; ROCHA, V. de O. (coords.). Tributos e preços de transferência. São Paulo: Dialética, 1999.

PISTONE, Pasquale. A necessidade de clareza na tributação e a aplicação da doutrina Acte Clair aos tributos diretos. In: COSTA, Alcides Jorge; SCHOUERI, Luís Eduardo e BONILHA, Paulo Celso Bergstrom (coord.), Direito Tributário Atual 21. São Paulo: Dialética, 2007. pp. 120-125.

RAAD, Kees van. Materials on international \& EU tax law. 11 ed. Leiden: International Tax Center, 2011. 2 v.

RAAD, Kees Van. Escopo geográfico das regras de distribuição da convenção modelo da OCDE. In: COSTA, Alcides Jorge; SCHOUERI, Luís Eduardo e BONILHA, Paulo Celso Bergstrom (coord.), Direito Tributário Atual 22. São Paulo: Dialética, 2008. pp. 101-107.

RAAD, Kees Van. Não-discriminação na tributação de operações transnacionais: escopo e questões conceituais. In: COSTA, Alcides Jorge; SCHOUERI, Luís Eduardo e BONILHA, Paulo Celso Bergstrom (coord.), Direito Tributário Atual 19. São Paulo: Dialética, 2005. pp. 52-63.

REZEK, José Francisco. Direito internacional público - curso elementar, 12 ed., São Paulo: Saraiva, 2010.

ROCHA, Antonio Jorge Ramalho da. O Brasil e os regimes internacionais. In: OLIVEIRA, Henrique Altemani e LESSA, Antônio Carlos (org.). Relações internacionais do Brasil: temas e agendas, v.2. São Paulo: Saraiva, 2006, pp.75-124.

RODI, Michael. Concorrência tributária internacional por investimentos. In: COSTA, Alcides Jorge; SCHOUERI, Luís Eduardo e BONILHA, Paulo Celso 
Bergstrom (coord.), Direito Tributário Atual 21. São Paulo: Dialética, 2007. pp. 126138.

ROXAN, Ian. Imputed income (including deductible costs). In: ESSERS, Peter e RIJKERS. Arie (org.). The notion of income from capital. Amsterdam: IBFD, 2005. pp. 249-261.

RUSSO, Raffaele (Ed.). RUSSO, Raffaele; PETRICCIONE Mario; MERKS, Paulus; FINNERTY, Chris. Fundamentals of international tax planning. Amsterdam: IBFD, 2007.

SACCHETTO, Claudio. A cooperação fiscal internacional: a troca de informações como instrumento de combate à evasão. In: COSTA, Alcides Jorge; SCHOUERI, Luís Eduardo e BONILHA, Paulo Celso Bergstrom (coord.), Direito Tributário Atual 22. São Paulo: Dialética, 2008. pp. 78-100.

SACCHETTO, Claudio. Política de tratados em matéria tributária para países emergentes vis-à-vis países desenvolvidos e em via de desenvolvimento. In: COSTA, Alcides Jorge; SCHOUERI, Luís Eduardo e BONILHA, Paulo Celso Bergstrom (coord.), Direito Tributário Atual 23. São Paulo: Dialética, 2009. pp. 72-87.

SCAFF, Fernando Facury. O direito tributário das futuras gerações. In: MARTINS, Ives Gandra da Silva (coord.), Tributação na internet. São Paulo: Centro de Extensão Universitária/Revista dos Tribunais, 2001( Pesquisas tributárias: nova série 7).

SCAFF, Fernando Facury. Efeitos da coisa julgada em matéria tributária e livre concorrência. In: Revista de Direito Público da Economia - RDPE, ano 4, n. 13, Belo Horizonte: Editora Fórum, 2006, pp. 141-164.

SCHWARZ, Jonathan S., Controlled Foreign Companies and Tax Treaties. In Bulletin for International Fiscal Documentation, dez, 1997, pp. 553-559.

SCHINDEL, Angel e ATCHABAHIAN, Adolfo, General Report, in Cahiers de Droit Fiscal International - Source and residence: new configuration of their principles, vol. 90a, Sdu Fiscale \& Financiële Uitgevers, The Netherlands, 2005, pp. 2299.

SCHOUERI, Luís Eduardo. Contribuição à história dos acordos de bitributação: a experiência brasileira. In: COSTA, Alcides Jorge; SCHOUERI, Luís Eduardo e BONILHA, Paulo Celso Bergstrom (coord.), Direito Tributário Atual 22. São Paulo: Dialética, 2008. pp. 267-287.

SCHOUERI, Luís Eduardo. Direito tributário. São Paulo: Saraiva, 2011.

SCHOUERI, Luís Eduardo. Direito tributário internacional. Acordos de bitributação. Imposto de renda: lucros auferidos por controladas e coligadas no exterior. Disponibilidade. Efeitos do artigo 74 da medida provisória $\mathrm{n}^{\circ}$ 2.158-35 - Parecer. In: COSTA, Alcides Jorge et SCHOUERI, Luís Eduardo (coord.), Direito Tributário Atual 16. São Paulo: Dialética, 2001. pp. 161-209. 
SCHOUERI, Luís Eduardo. Direito tributário internacional - Qualificação e substituição - Tributação, no Brasil, de rendimentos provenientes de sociedades residentes na Alemanha. In: Revista Dialética de Direito Tributário $n^{o}$ 54. São Paulo: Dialética, 2000, pp.125-139.

SCHOUERI, Luís Eduardo. Imposto de renda e comércio eletrônico. In: COSTA, Alcides Jorge et SCHOUERI, Luís Eduardo (coord.), Direito Tributário Atual 16. São Paulo: Dialética, 2001. pp. 146-160.

SCHOUERI, Luís Eduardo. Normas tributárias indutoras e intervenção econômica. Rio de Janeiro: Forense, 2005.

SCHOUERI, Luís Eduardo. O mito do lucro real na passagem da disponibilidade jurídica para a disponibilidade econômica. In: MOSQUERA, Roberto Quiroga e BROEDEL, Alexsandro (org.). Controvérsias jurídico-contábeis - aproximações e distanciamentos, pp. 241-264.

SCHOUERI, Luís Eduardo. Preços de Transferência no Direito Tributário Brasileiro. $2^{\mathrm{a}}$ ed. São Paulo: Dialética, 2006.

SCHOUERI, Luís Eduardo. Princípios no direito tributário internacional: territorialidade, fonte e universalidade. In: FERRAZ, Roberto Catalano Botelho (coord.), Princípios e limites da tributação. São Paulo: Quartier Latin, 2005. pp. 321374.

SCHOUERI, Luís Eduardo. Tax sparing: reconsideração da reconsideração. In: OLIVEIRA, Ricardo Mariz; SCHOUERI, Luís Eduardo; ZILVETI, Fernando Aurélio (coord.), Direito Tributário Atual 26. São Paulo: Dialética, 2011. pp. 93-108.

SCHOUERI, Luís Eduardo. Tratados e convenções internacionais sobre tributação. In: COSTA, Alcides Jorge; SCHOUERI, Luís Eduardo e BONILHA, Paulo Celso Bergstrom (coord.), Direito Tributário Atual 17. São Paulo: Dialética, 2003. pp. 20-49.

SCHOUERI, Luís Eduardo. Tributação e Indução Econômica: os efeitos econômicos de um tributo como critério para sua constitucionalidade. In: FERRAZ, Roberto Catalano Botelho (coord.), Princípios e limites da tributação 2. São Paulo: Quartier Latin, 2009. pp. 139-164.

SEN, Amartya Kumar. Desenvolvimento como liberdade. Tradução Laura Teixeira Motta; revisão técnica Ricardo Doniselli Mendes. 8. ed. São Paulo: Companhia das Letras, 2009.

SILVA. Virgílio Afonso da. Direitos fundamentais: conteúdo essencial, restrições e eficácia.São Paulo: Malheiros Editores, 2011.

SILVA, Gerson Augusto da. A política tributária como instrumento do desenvolvimento, 2. ed. Brasília: Esaf, 2009. 
SILVA, Mauro. Da competição à cooperação tributária internacional: aspectos jurídicos da promoção do desenvolvimento nacional num cenário internacionalizado. Tese de Doutorado - Faculdade de Direito da USP, São Paulo, 2009.

SILVA, Mauro. Direito ao desenvolvimento e fonte de pagamento: em busca dos fundamentos jurídicos para a divisão estatal do poder de tributar a renda. In: COSTA, Alcides Jorge; SCHOUERI, Luís Eduardo e BONILHA, Paulo Celso Bergstrom (coord.), Direito Tributário Atual 19. São Paulo: Dialética, 2005. pp. 164-191.

SILVA, Natalie Matos. A integração da tributação das pessoas jurídicas e das pessoas físicas: análise dos modelos teóricos e de sua adequação ao princípio da capacidade contributiva. In: COSTA, Alcides Jorge; SCHOUERI, Luís Eduardo; BONILHA, Paulo Celso Bergstrom (coord.), Direito Tributário Atual 23. São Paulo: Dialética, 2009. pp. 366-402.

SILVEIRA, Eduardo Teixeira. O regime jurídico do investimento estrangeiro no Brasil. In: In: TÔRRES, Heleno Taveira (coord.). Direito tributário internacional aplicado. São Paulo: Quartier Latin. 2003.

SILVEIRA, Ricardo Maitto da. O princípio da realização da renda no direito tributário brasileiro. In: COSTA, Alcides Jorge; SCHOUERI, Luís Eduardo e BONILHA, Paulo Celso Bergstrom (coord.), Direito Tributário Atual 21. São Paulo: Dialética, 2007 pp. 317-344.

SKAAR, Arvid Aage. Erosion of the concept of permanent establishment: electronic commerce. In: Intertax, v. 28, 2000, pp. 188-194.

SKAAR, Arvid Aage. Tax policy forum: the legal nature of mutual agreements under tax treaties. Tax Notes International Magazine, 5 Tax Notes Int'l 1441, 1992.

SOUSA, Rubens Gomes de. Imposto de renda: despesas não dedutíveis pelas pessoas jurídicas. Seu tratamento fiscal como lucros distribuídos no que se refere à própria sociedade e a seus sócios ou acionistas. In: SOUSA, R.G. de (coord). Pareceres-1 Imposto de Renda, Edição póstuma. São Paulo:IBET: Resenha Tributária, 1975. pp.59-95.

STIGLITZ, Joseph. E. Economics of the public sector. 3.ed. Nova York/Londres:WW Norton. 2000, pp.661-674.

TANZI, Vito. Globalization, tax Competition by the future of tax systems. In: UCKMAR, Victor (org.). Corso di diritto tributario internazionale, 2 ed., Padova: CEDAM, 2002, pp.21-41.

TAVOLARO, Agostinho Toffoli. Territorialidade e tributação. In: SCHOUERI, Luís Eduardo. (coord.), Direito tributário - Homenagem a Paulo de Barros Carvalho. São Paulo: Quartier Latin, 2008. pp. 793-814.

TAVOLARO, Agostinho Toffoli. Tratado Brasil/Estados Unidos para evitar a dupla tributação. In: Filho, C.P.; Tonani, F.; Behrndt M.A.; Ribeiro, R.P; Vasconcellos, 
R.F. (coord.), Revista de direito tributário internacional. Ano 5, nº15, São Paulo: Quartier Latin, 2010, pp. 9-60.

TAVOLARO, Agostinho Toffoli. Tratados para evitar a dupla tributação internacional. In: MARTINS, Ives Gandra da Silva (coord.), Curso de direito tributário. 12. ed. São Paulo: Saraiva, 2010. pp. 563-614.

TAYLOR, Willard B. O que um acordo de bitributação entre Brasil e EUA poderia estipular? In: COSTA, Alcides Jorge; SCHOUERI, Luís Eduardo e BONILHA, Paulo Celso Bergstrom (coord.), Direito Tributário Atual 21. São Paulo: Dialética, 2007. pp. 151-157.

TESAURO, Francesco. Instituzioni di diritto tributario, v.2, 7 ed. Torino: UTET, 2005.

THORSTENSEN, Vera. OMC - As regras do comércio internacional e a nova rodada de negociações multilaterais. 2.ed. São Paulo: Aduaneiras, 2003.

TILLINGHAST, David. Internet: the impact of the internet on the taxation of international transactions. In: Bulletin for international fiscal documentation, nov/dez, 1997, pp. 524-526

TIPKE, Klaus et LANG, Joachim. Direito tributário (Steuerrecht), v. 1.. Tradução: Luiz Dória Furquim. Porto Alegre: Sergio Antonio Fabris, 2008.

TIPKE, Klaus; YAMASHITA, Douglas. Justiça fiscal e princípio da capacidade contributiva. São Paulo: Malheiros Editores, 2002.

TIPKE, Klaus. Sobre a unidade da ordem jurídica tributária. In: SCHOUERI, L.E. e ZILVETI, F. A. (coord.), Direito tributário - Estudos em homenagem a Brandão Machado. São Paulo: Dialética, 1998, pp.60-70.

TORRES, Ricardo Lobo. A segurança jurídica e as limitações constitucionais ao poder de tributar. In: FERRAZ, Roberto Catalano Botelho (coord.), Princípios e limites da tributação. São Paulo: Quartier Latin, 2005. pp. 427-446.

TORRES, Ricardo Lobo. Curso de direito financeiro e tributário. 12. ed. Rio de Janeiro: Renovar, 2005.

TORRES, Ricardo Lobo. Interação entre princípios constitucionais tributários e princípios da ordem econômica. In: FERRAZ, Roberto Catalano Botelho (coord.), Princípios e limites da tributação 2. São Paulo: Quartier Latin, 2009. pp. 491-518.

TORRES, Ricardo Lobo. Segurança jurídica e sociedade de risco. In: SCHOUERI, Luís Eduardo. (coord.), Direito tributário - Homenagem a Paulo de Barros Carvalho. São Paulo: Quartier Latin, 2008. pp. 255-268.

TORRES, Ricardo Lobo. Tratado de direito constitucional financeiro $e$ tributário- valores e princípios constitucionais tributários, v. II. Rio de Janeiro: Renovar, 2005. 
TÔRRES, Heleno Taveira. Pluritributação internacional sobre as rendas de empresas. 2. ed. São Paulo: Revista dos Tribunais. 2001.

TÔRRES, Heleno Taveira. Princípio da Territorialidade e tributação de nãoresidentes no Brasil. Prestações de serviços no exterior. Fonte de produção e fonte de pagamento. In: TÔRRES, Heleno Taveira. (coord.), Direito Tributário Internacional Aplicado. São Paulo: Quartier Latin, 2003. pp. 71-108.

TREBILCOCK, Michael; HOWSE, Robert. The regulation of international trade. 3. ed. Oxon: Taylor \& Francis, 2005.

UCKMAR, Victor; CORASANITI,Giuseppe; VIMERCATE, Paolo De'Capitani. Diritto Tributário Internazionale - Manuale. In: UCKMAR, Victor et UCKMAR, Antonio (Coord.). Il diritto tributário, Serie I, CVII. Padova: CEDAM, 2009.

UTUMI, Ana Claudia Akie. Países com tributação favorecida no direito brasileiro. in TÔRRES, Heleno Taveira (coord.) - Direito tributário internacional aplicado. São Paulo: Quartier Latin, 2003.

VETTORI, Gustavo Gonçalves. Contribuição ao estudo sobre as influências recíprocas entre a tributação da renda e o comércio internacional. Tese de doutorado Faculdade de Direito da USP, São Paulo, 2011.

VASCONCELLOS, Roberto França de. Tributação do comércio eletrônico internacional. Tese de doutorado - Faculdade de Direito da USP, São Paulo, 2002.

VOGEL, Klaus. "Klaus Vogel on Double Taxation Conventions. Editora Kluwer, $3^{\text {rd }}$ edition, 1997.

VOGEL, Klaus. Harmonia decisória e problemática da qualificação nos acordos de bitributação. In Estudos em Homenagem a Brandão Machado (Coord. Luis Eduardo Schoueri e Fernando A. Zilveti). São Paulo: Dialética, 1998, p. 71-81. 2005 .

WALTER, Roland. Fiches de droit fiscal international. Paris: Editions Ellipses,

XAVIER, Alberto. Direito tributário internacional do Brasil. 6. ed. Rio de Janeiro: Forense, 2005.

ZILVETI, Fernando Aurélio. O princípio da realização da renda. In: SCHOUERI, Luís Eduardo (org.). Direito tributário - homenagem a Alcides Jorge Costa, v. 1. São Paulo: Quartier Latin, 2003, pp. 297-328. 


\title{
LEGISLAÇÃO
}

ESTADOS UNIDOS DA AMÉRICA. Income Tax Regulations. Chicago-IL: CCH Editorial Staff Publication, 2003. 6 v.

ESTADOS UNIDOS DA AMÉRICA. Internal Revenue Code. Chicago-IL: CCH Editorial Staff Publication, 2003. 2 v.

\section{FONTES DA INTERNET}

\begin{abstract}
ALMEIDA, Aloísio Flávio Ferreira de. Tax havens: an analysis of the OECD work with policy recommendations. Disponível em: http://isentos.receita.fazenda.gov.br/Publico/estudotributarios/TrabAcademicos/Resumo s/AloisioTaxHavensabstract.pdf. Acesso em: 10 nov 2010.
\end{abstract}

AVI-YONAH, Reuven S. Avi-Yonah, Reuven S. The OECD Harmful Tax Competition Report: A Tenth Anniversary Retrospective (August 1, 2008). University of Michigan Public Law Working Paper No. 115. Disponível em: http://ssrn.com/abstract=1194942. Acesso em: 11 nov 2010.

BANCO MUNDIAL e CORPORAÇÃO FINANCEIRA INTERNACIONAL. Barreiras jurídicas, administrativas e políticas aos investimentos no Brasil, v. 1, junho 2001. Disponível em: http://siteresources.worldbank.org/BRAZILINPOREXTN/Resources/38171661185895645304/4044168-1186403960425/05V1.pdf. Acesso em 15 dez 2011.

BANCO MUNDIAL; CORPORAÇÃO FINANCEIRA INTERNACIONAL e PRICEWATERHOUSECOOPERS. Paying taxes 2011: the global picture. Disponível em: http://www.pwc.com/gx/en/paying-taxes/pdf/paying-taxes-2011.pdf. Acesso em 15 dez 2011.

BÉNASSY-QUÉRÉ, Agnès; FONTAGNE, Lionel Gerard e LAHRECHEREVIL, Amina. How Does FDI React to Corporate Taxation? In: International Tax and Public Finance, V. 12, $\mathrm{n}^{\mathrm{o}}$ 5, 2005. Disponível em: http://ssrn.com/abstract=1260868. Acesso em 15 set 2011.

BROOKS, Kimberley. Using the tax system to promote investment in low-income countries: an illustration of good intentions, bad results. In: Globalization and the impact of tax on international investments: a symposium in honor of the late Alex Eason. Queen's University, Faculty of Law. February, 2008. Disponível em http://law.queensu.ca/events/recentConferences/eassonSymposiumDratPapers/kimBroo ksTaxSparingFeb242008.doc. Acesso em 07 out 2011.

CONSELHO ADMINISTRATIVO DE RECURSOS FISCAIS. Câmara Superior de Recursos Fiscais, $1^{a}$ T, Acórdão 9101-00287 de 24/08/09. Rel. Adriana Gomes Rêgo. Disponível em www.carf.fazenda.gov.br. Acesso em 30 nov 2011. 
CORTE EUROPÉIA DE JUSTIÇA. Caso Marks \& Spencer (C-446/03). Disponível em www.curia.europa.eu/juris/liste.jsf?language-en\&num-c-446/03. Acesso em 15 dez 2011

EDEN, Lorraine e KUDRLE, Robert T. Tax havens: renegade in the international tax regime? Law \& Policy, v. 27, n. 1. Baldy Center for Law and Social Policy and Blackwell Publishing Ltd. 2005. Disponível em: <http://voxprof.com/eden/Publications/eden-kudrle-law-and-policy-tax-havens.pdf >. Acesso em 05 nov 2011.

GENSCHEL, Phillip, Globalization, tax competition, and the fiscal viability of the welfare state. Working papers, Max Planck Institute for the Study of Societies, 2001. Disponível em: http://www.mpifg.de/pu/workpap/wp01-1/wp01-1.html. Acesso em 04 nov 2011.

GONÇALVES, Reinaldo. A internacionalização da produção: uma teoria geral? Revista de Economia Política, v. 4, nº 1, jan-mar/1984. Disponível em: http://www.rep.org.br/pdf/13-7.pdf. Acesso em 20 dez 2011.

G20. Declaration on Strengthening the Financial System. Disponível em: www.g20.org. Acesso em $01 \mathrm{dez} 2011$.

HINES Jr., James R. Tax sparing and direct investment in developing countries. NBER - National Bureau of Economic Research, Working Paper n. 6728/2000. Disponível em: http://www.nber.org/papers/w6728.pdf?new_window=1. Acesso em 07 out 2011.

INSTITUTO BRASILEIRO DE DIREITO TRIBUTÁRIO. Ata da mesa de debates em 12 de março de 2009. Disponível em www.ibdt.com.br/material/arquivos/Atas/Integra_12032009.htm. Acesso 28 dez 2011.

INSTITUTO BRASILEIRO DE DIREITO TRIBUTÁRIO. Ata da mesa de debates em 08 de abril de 2010. Disponível em www.ibdt.com.br/material/arquivos/Atas/Integra_08042010.htm. Acesso $28 \mathrm{dez} 2011$.

KPMG, Corporate and Indirect Tax Rates Survey 2010. Disponível em: http://www.kpmg.com/lu/en/issuesandinsights/articlespublications/pages/kpmg'scorpora teandindirecttaxratesurvey2010.aspx. Acesso em 07 nov 2011.

MA, Shi Qi. Country Analyses: China. In: International Bureau of Fiscal Documentation Tax Research Plataform. Disponível em: www.ibfd.org. Acesso em 17 $\operatorname{dez} 2011$.

MASSONE, Pedro. Country Analyses: Chile. In: International Bureau of Fiscal Documentation Tax Research Plataform. Disponível em: www.ibfd.org. Acesso em 17 $\operatorname{dez} 2011$.

OBAMA, Barack. The president's record on jobs and the economy. Disponível em http://www.barackobama.com/record/economy/. Acesso em $20 \mathrm{dez} 2011$. 
ORGANIZAÇÃO MUNDIAL DO COMÉRCIO. Understanding the WTO: the agreements. http://www.wto.org/english/thewto_e/whatis_e/tif_e/agrm8_e.htm\#subsidies. Acesso em 18 dez 2011.

ORGANIZAÇÃO DAS NAÇÕES UNIDAS. United Nations Model Tax Convention $\quad$ Update, Disponível em: http://www.un.org/esa/ffd/tax/sixthsession/UN-ModelTaxConvention.pdf. Acesso em 7 out 2011.

ORGANIZAÇÃO DAS NAÇÕES UNIDAS, United Nations Model double taxation convention between developed and developing countries, 2001. Disponível em: www.un.org/esa/ffd/documents/DoubleTaxation.pdf. Acesso em 15 out 2011.

ORGANIZAÇÃO PARA COOPERAÇÃO E DESENVOLVIMENTO ECONÔMICO. A Progress Report on the Jurisdictions Surveyed by the OECD Global Forum in Implementing The Internationally Agreed Tax Standard, 2011. Disponível em: www.oced.org. Acesso em 15 nov 2011.

. The OECD's Project on Harmful Tax Practices: The 1998 Report. Disponível em: www.oecd.org. Acesso em 02 nov 2011.

. Exchange of Tax Information Portal. Disponível em: http://www.eoi-tax.org/jurisdictions. Acesso em 15 nov 2011.

Improving Acess to Bank Information for Tax Purposes, 2000. Disponível em: www.oecd.org. Acesso em 15 nov 2011.

Towards Global Tax Co-operation. Progress in Identifying and Eliminating Harmful Tax Practices. 2000. Disponível em: www.oecd.org. Acesso em 15 nov 2011.

The OECD's Project on Harmful Tax Practices: The 2001 Progress Report. Disponível em: www.oecd.org. Acesso em 15 nov 2011.

Agreement on Exchange of information on tax matters, 2002. Disponível em: www.oecd.org. Acesso em 15 nov 2011.

The OECD's Project on Harmful Tax Practices: The 2004 Progress Report. Disponível em: www.oecd.org. Acesso em 10 nov 2011.

Tax Co-operation: Towards a Level Playing Field - 2006 Assessment by the Global Forum on Taxation, 2006. Disponível em: www.oecd.org. Acesso em 15 nov 2011.

. Tax Co-operation: Towards a Level Playing Field - 2007 Assessment by the Global Forum on Taxation, 2007. Disponível em: www.oecd.org. Acesso em 15 nov 2011. 
- Tax Co-operation: Towards a Level Playing Field - 2008 Assessment by the Global Forum on Taxation, 2008. Disponível em: www.oecd.org. Acesso em 15 nov 2011.

. Model tax convention with respect to taxes on income and on capital, 2008. Disponível em: www.oecd.org. Acesso em 10 nov 2011.

Tax Co-operation: Towards a Level Playing Field - 2009 Assessment by the Global Forum on Taxation, 2009. Disponível em: www.oecd.org. Acesso em 07 nov 2011.

Tax sparing a reconsideration. Disponível em: http://books.google.com/books?id=J7MFIiQHD8wC\&printsec=frontcover\&hl=pt-

$\mathrm{BR} \&$ source $=\mathrm{gbs}$ ge_summary_r\&cad$=0 \# \mathrm{v}=$ onepage $\& \mathrm{q} \& \mathrm{f}=$ false. Acesso em 07 out 2011.

. OECD tax database. http://www.oecd-ilibrary.org/taxation/total-taxrevenue_20758510-table2. Acesso em 17 out 2011

PERDELWITZ, Andreas. Country Analyses: Germany. In: International Bureau of Fiscal Documentation Tax Research Plataform. Disponível em www.ibfd.org. Acesso em $17 \mathrm{dez} 2011$.

PUREZA, Maria Emilia Miranda Pureza. Disciplinamento das renúncias de receitas federais - inconsistências no controle dos gastos tributários. Disponível em: http://www2.camara.gov.br/atividade-

legislativa/orcamentobrasil/orcamentouniao/estudos/2007/Estudo052007.pdf. Acesso em 07 set. 2011.

RECEITA FEDERAL DO BRASIL. O Brasil e o comércio eletrônico. Brasília, 2001. Disponível em: http://www.receita.fazenda.gov.br/Publico/estudotributarios/estatisticas/13BrasilComer cioEletronico.pdf. Acesso em 12 set 2011.

RECEITA FEDERAL DO BRASIL. Carga Tributária no Brasil 2010. Disponível em:http://www.receita.fazenda.gov.br/Publico/estudoTributarios/estatisticas/CTB2010.p df. Acesso em 17 out 2011.

RECEITA FEDERAL DO BRASIL. Demonstrativo dos gastos tributários 2011. Brasília, 2010. Disponível em: http://www.receita.fazenda.gov.br/publico/EstudoTributario/BensTributarios/2011/DGT 2011.pdf. Acesso em 24 set 2011.

RECEITA FEDERAL DO BRASIL. Memória Receita Federal - Imposto de renda pessoa física. Disponível em :http://www.receita.fazenda.gov.br/Memoria/irpf/historia/hist1964a1967.asp, a Acesso em 30 out 2011. 
ROBLES, Arturo Pérez. Country Analyses: Mexico. In: International Bureau of Fiscal Documentation Tax Research Plataform. Disponível em www.ibfd.org. Acesso em $17 \mathrm{dez} 2011$.

SCHOUERI, Luís Eduardo. Tributação e Cooperação Internacional. Revista Fórum de Direito Tributário - RFDT, Belo Horizonte, n. 7, jan./fev. 2004. Disponívelem:http://www.editoraforum.com.br/sist/conteudo/lista_conteudo.asp?FIDT_ CONTEUDO=13471> Acesso em: 19 set. 2011.

SUSARLA, Kamesh. Country Analyses: India. In: International Bureau of Fiscal Documentation Tax Research Plataform. Disponível em www.ibfd.org. Acesso em 18 $\operatorname{dez} 2011$.

TAVOLARO, Agostinho Toffoli. Impostos abrangidos pelos tratados de dupla tributação. Disponível em: http://www.tavolaroadvogados.com/doutrina/cs805.doc. Acesso em 07 out 2011.

TAVOLARO, Agostinho Toffoli. $O$ estabelecimento permanente: instituto próprio do direito tributário internacional. Disponível em: http://www.tavolaroadvogados.com/doutrina/cs495.doc. Acesso em 07 dez 2011.

TESOURO NACIONAL. Demonstrações Contábeis da União, 2010, p.9. Disponível em: http://www.tesouro.fazenda.gov.br/contabilidade_governamental/download/BGU_sintet ico.pdf. Acesso em 17 out 2011.

THE ECONOMIST NEWSPAPER LIMITED. The G-20 and tax - haven hypocrisy. Disponível em: www.economist.com. Acesso em 16 nov 2010.

THORSTENSEN, Vera. O Brasil frente a um tríplice desafio - As negociações simultâneas da OMC, da ALCA e do acordo CE/MERCOSUL. Instituto de Estudos Econômicos Internacionais. Cadernos do Fórum Euro-Latino-Americano. Disponível em : www.ieei.pt/files/WP9_VThorstensen.pdf.

TORRES, Ricardo Lobo. O princípio da transparência no direito financeiro. Disponível em: www.mundojuridico.adv.br. Acesso em 24 out 2011.

TRIBUNAL DE CONTAS DA UNIÃO. Simplified version of the General Government Accounts of the Republic 2009. Disponível em: http://portal2.tcu.gov.br/portal/pls/portal/docs/2056554.PDF. Acesso em 17 out 2011.

UNCTAD. Tax incentives and foreign direct investment: a global survey. ASIT Advisory Studies $\mathrm{n}^{\mathrm{o}}$ 16. New York e Geneva, 2000. Disponível em: http://www.unctad.org/en/docs/iteipcmisc3_en.pdf. Acesso em 20 dez 2011.

UNCTAD, World Investment Report 2011. Disponível em: http://www.unctad.org/Templates/webflyer.asp?docid=15189\&intItemID=2068\&lang= $1 \&$ mode $=$ downloads. Acesso em 10 out 2011. 